\title{
COMBINED BUILDING INTEGRATED PHOTOVOLTAIC-THERMAL COLLECTOR WITH AIR SOURCE HEAT PUMP FOR COLD CLIMATE
}

\author{
by
}

\begin{abstract}
Raghad Sabah Kamel
Bachelor of Applied Science (Mechanical Engineering), University of Baghdad (Iraq), 1995 Master of Applied Science (Mechanical Engineering), University of Baghdad (Iraq), 1998
\end{abstract}

\author{
A dissertation \\ presented to Ryerson University \\ in partial fulfillment of the degree of \\ Doctor of Philosophy \\ In the program of \\ Mechanical Engineering
}

Toronto, Ontario, Canada, 2015

CRaghad S. Kamel 2015 


\section{Author's Declaration}

I hereby declare that I am the sole author of this dissertation. This is a true copy of the dissertation, including any required final revisions, as accepted by my examiners.

I authorize Ryerson University to lend this thesis to other institutions or individuals for the purpose of scholarly research.

I further authorize Ryerson University to reproduce this thesis by photocopying or by other means, at the request of other institutions or individuals for the purpose of scholarly research.

I understand that my dissertation may be made electronically available to the public. 


\title{
COMBINED BUILDING INTEGRATED PHOTOVOLTAIC-THERMAL COLLECTOR WITH AIR SOURCE HEAT PUMP FOR COLD CLIMATE
}

\author{
Raghad Sabah Kamel \\ Doctor of Philosophy \\ Department of Mechanical and Industrial Engineering \\ Ryerson University, Toronto, Ontario, Canada, 2015
}

\begin{abstract}
A TRNSYS model was developed to conduct a comprehensive study of combining a building integrated photovoltaic thermal (BIPV/T) collector with an air source heat pump (ASHP) in an Archetype Sustainable House. The heat pump uses the warm air generated in the BIPV/T as the source for heat production. The coupling of BIPV/T and ASHP enables a highly efficient heating system in winter conditions. A numerical model was developed for an air-based PV/T collector. The model was used to predict the thermal and electrical performance of the collector and to conduct a comprehensive analysis for different configurations (number of PV/T panels in rows $\mathrm{N}_{R}$ and in series $\mathrm{N}_{\mathrm{S}}$ ) and different design parameters. TRNSYS simulation results showed that low air mass flow rate and low duct depth enhance the heat pump coefficient of performance (COP). The arrangement with a large number of PV/T systems connected in series has higher COP. The maximum obtained seasonal heating $\mathrm{COP}$ was 3.45 , corresponding to duct depth of $1.5 \mathrm{in}, N_{S}=5$ and low row mass flow rate of $0.03 \mathrm{~kg} / \mathrm{s}$. The heat pump cumulative electricity consumption for a typical heating season could be reduced by $20.2 \%$. When the analysis was based only on sunny hours, the electricity consumption of the combined ASHP + PV/T system was reduced by $52 \%$ and the predicted seasonal COP of the heat pump was 5.98. A new full-scale test facility was
\end{abstract}


presented to be implemented at Toronto and Region Conservation Authority to examine the performance of combining passive system and dynamic building envelope technologies (BIPV/T+ASHP+TES) under real weather conditions. It is important to match the maximum airflow for the BIPV/T system with the maximum airflow for the outdoor coil of the heat pump. The pressure drop inside the PV/T collector along with the connecting air duct from the BIPV/T to ASHP for a wide range of airflow rates and different duct depths was calculated. It was found that for air a flow rate around 2000 CFM, which is the maximum CFM for the custom-made ASHP for the test facility, the predicted fan energy was $195 \mathrm{kWh}$ /year corresponding to $1.5 \mathrm{in}$. duct depth. 


\section{Acknowledgements}

I would like to express my great thankful and appreciation to my supervisor Dr. Alan Fung for his valuable suggestions and helpful support throughout the time and development of this research. Also, I would like to thank Dr. David Naylor and Dr. Wey Leong for their time and willingness to guide and provide the technical support. Without their motivation, unlimited help and interest, I would not be able to accomplish the dissertation successfully.

My special thanks to Mr. Steve Davies and the staff in Ecologix company for their support and time.

I would like to thank Toronto Atmosphere Fund (TAF), Mitacs, S2e Technologies, Ecologix Heating Technologies Inc., Connect Canada, Natural Sciences and Engineering Research Council (NSERC) of Canada, and Centre of Urban Energy for funding this project.

I would like to thank the following companies for their effort, knowledge and support: Amvic Building System, Toronto and Region Conservation Authority (TRCA), and Lafarge.

I am so grateful to all my friends Navid Ekrami, Farzin Rad, Edward Vuong, Tamima Ahmed, and Afarin Amirirad for their support. Special acknowledgment to students who worked during summer time: Quentin Noire, Mathieu Roirand, Tobias Kuehn, Edouard Leignel, Vitali Mueller.

Last but not least, my grateful and deep love for my kindhearted husband, Adnan, for his support and standing by my side in difficult times. 


\section{Dedication}

My work is dedicated to my:

Mother

Father (in his memory)

Brother: Ahmed

Sisters: Rana, Warda and Sara

And

My soul mate: Adnan 


\section{Table of Contents}

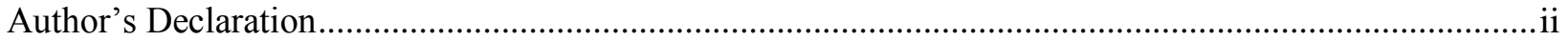

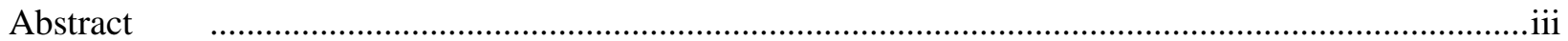

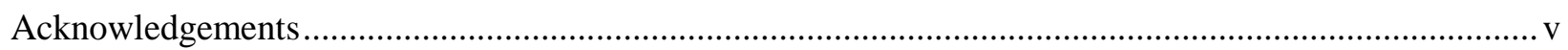

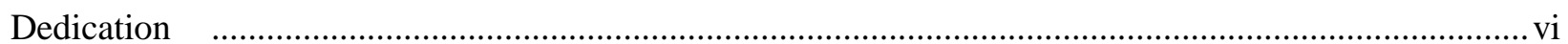

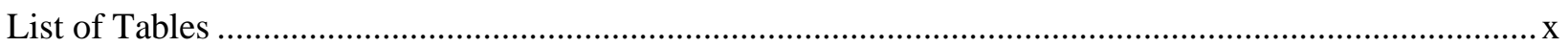

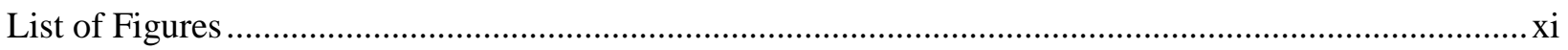

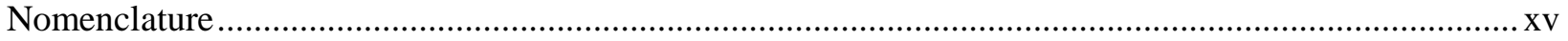

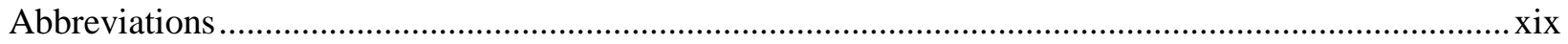

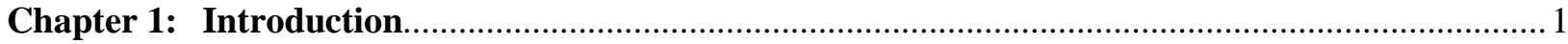

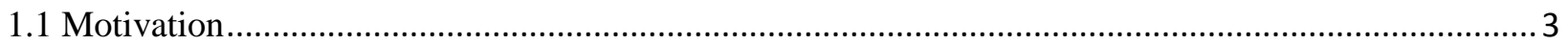

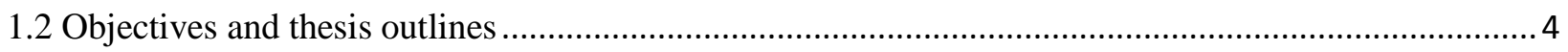

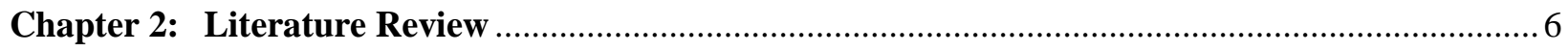

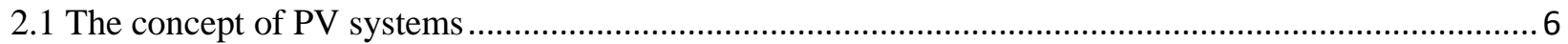

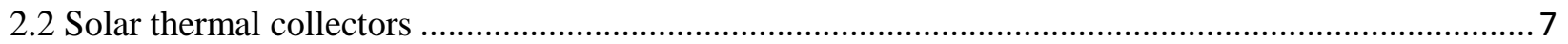

2.3 Hybrid Photovoltaic-Thermal (PV/T) collector ............................................................................ 8

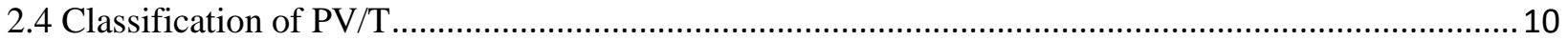

2.5 Building integrated PV/T: design and installations ..................................................................... 11

2.6 Performance analysis and improvement of BIPV/T system ....................................................... 14

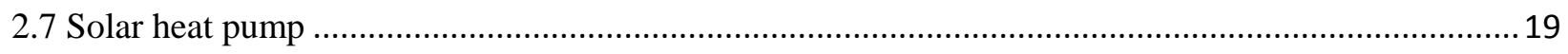

2.8 Solar assisted heat pump system classification ............................................................................ 19

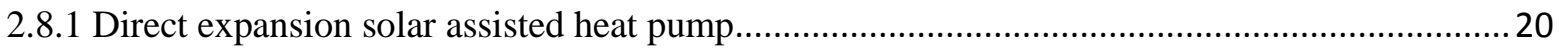

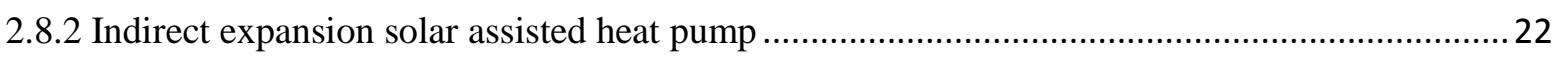

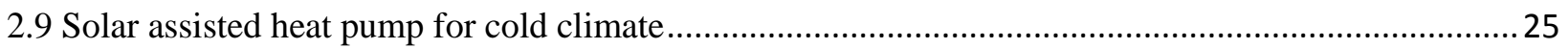

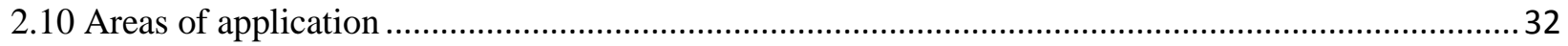

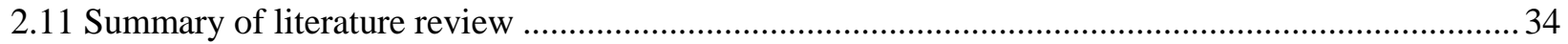

Chapter 3: Modeling of Opaque Photovoltaic-Thermal (PV/T) Collector ....................................... 36

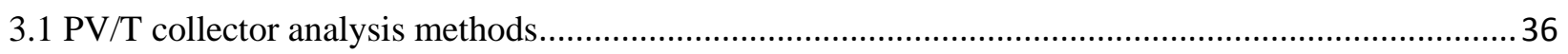

3.2 Energy model of a hybrid Photovoltaic-Thermal (PV/T) air collector ...........................................37

3.2.1 Estimation of Heat Transfer Coefficients ............................................................................ 39 


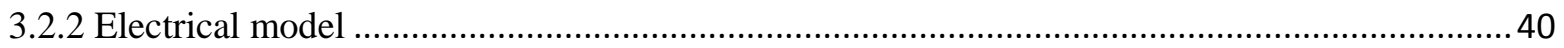

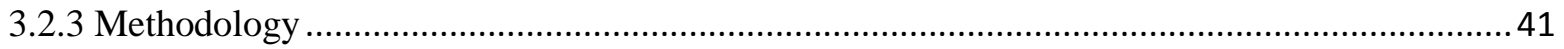

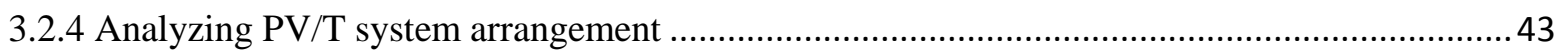

3.3 Building Integrated Photovoltaic-Thermal Collector system (BIPV/T) .........................................50

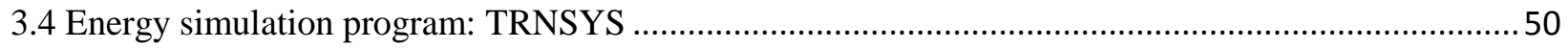

3.4.1 Existing BIPV/T component in TRNSYS...................................................................... 51

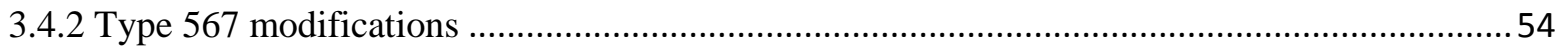

3.4.2.2 Incident Angle Modifier (IAM) modification ...........................................................5 54

3.4.2.3 Reynolds number and Nusselt number modification .................................................57

3.4.2.4 Equation block: Top convective heat loss coefficient...................................................58

3.5 Modeling of opaque BIPV/T system within a building envelope ...................................................58

3.5.1 Thermal interaction between BIPV/T type and building model (Type 56) during the simulation 59

3.5.2 Impact of different parameters on BIPV/T performance .................................................60

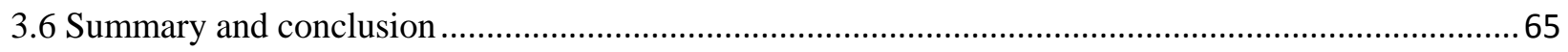

Chapter 4: Modeling of Transparent Backing Building Integrated Photovoltaic-Thermal Collector .66

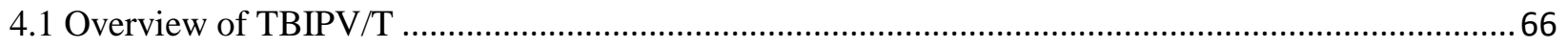

4.2 Modeling and energy analysis of transparent photovoltaic/thermal collector ..................................67

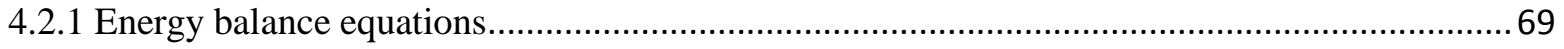

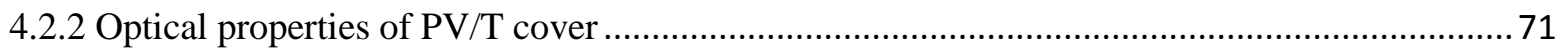

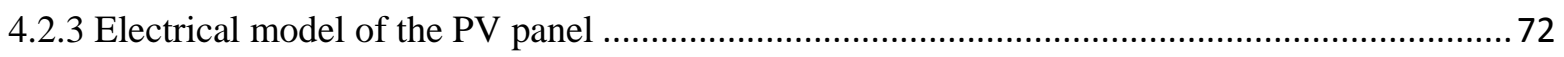

4.3 Type 211: Transparent building integrated PV/T system ............................................................ 73

4.4 Sensitivity analysis of different parameters .............................................................................. 76

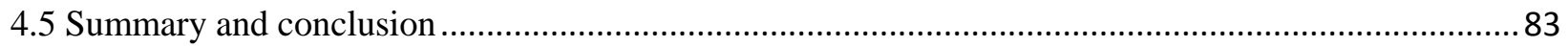

Chapter 5: Modeling, Simulation and Feasibility Analysis of Residential BIPV/T+ASHP System in

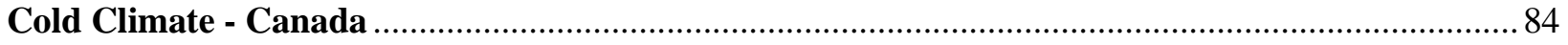

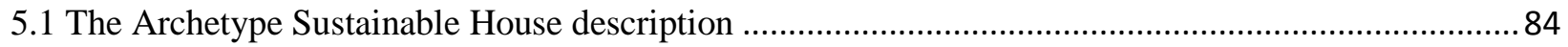

5.1.1 House-A: The mechanical system and the TRNSYS model ............................................. 85

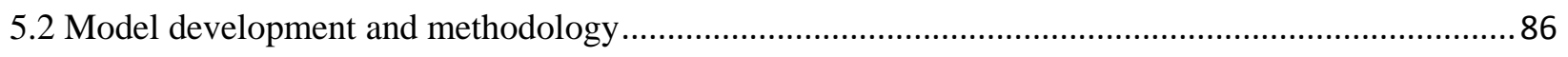

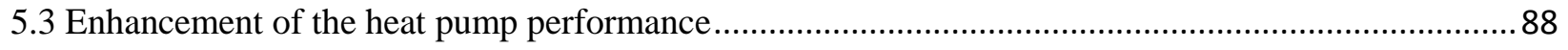

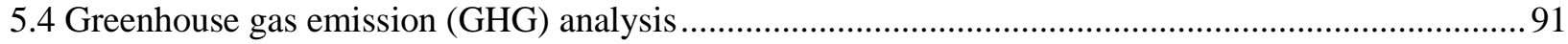

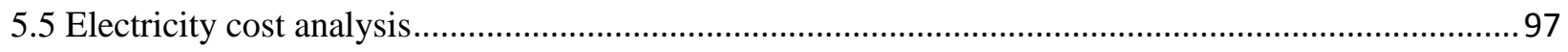




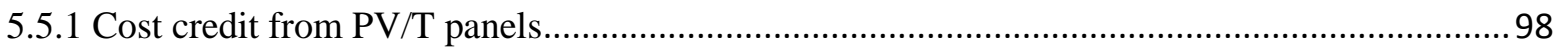

5.6 Solar assisted heat pump performance in selected Canadian regions .............................................100

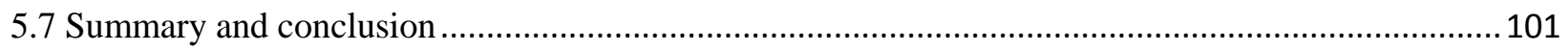

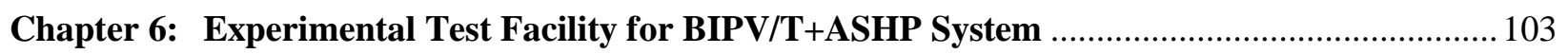

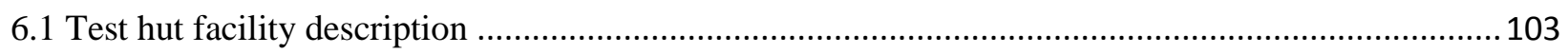

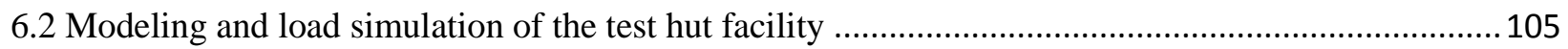

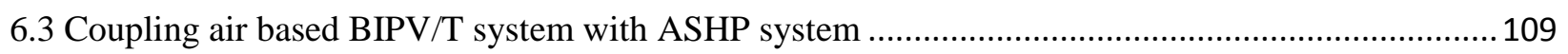

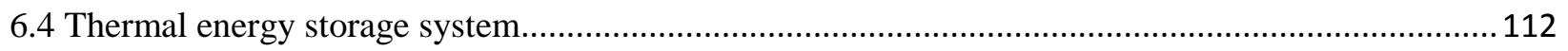

6.4.1 Insulated Concrete Forms (ICF) walls ........................................................................... 112

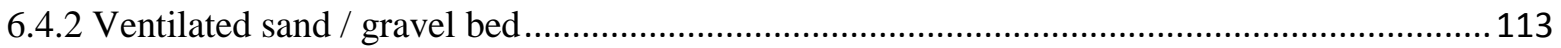

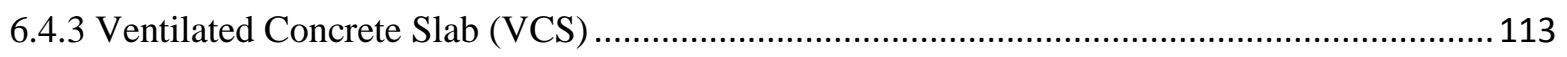

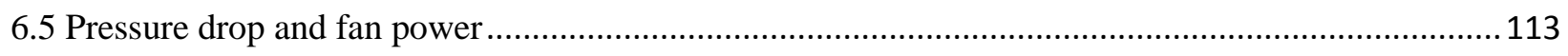

6.5.1 Pressure drop calculation for BIPV/T system …............................................................ 114

6.5.2 Duct design and pressure drop for coupling BIPV/T system with ASHP............................. 118

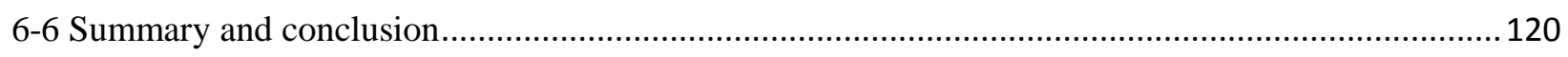

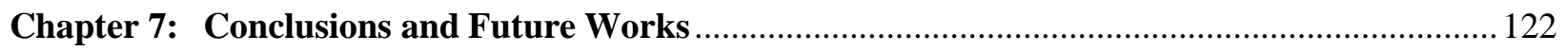

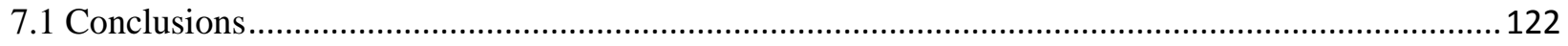

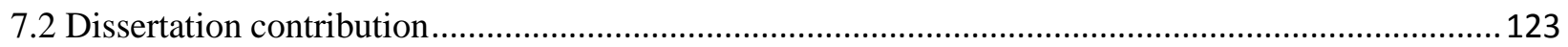

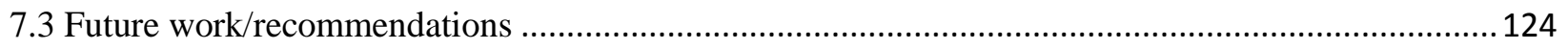

Appendix A: Definition of the Relations used in Energy Balance Equations in Section 3.2 ............. 126

Appendix B: Type 211: Transparent Backing Building-Integrated Photovoltaic Thermal System...........

Appendix C: $\quad$ FORTRAN Code of TRNSYS Type 211: Transparent backing BIPV/T ...................... 132

Appendix D: $\quad$ Engineering Drawing of the Test Hut Facility at TRCA............................................. 147

Appendix E: Additional Pictures for the Test Hut Facility .......................................................... 151

Appendix F: $\quad$ List of Journal and Conference Publications from this Research ............................... 155

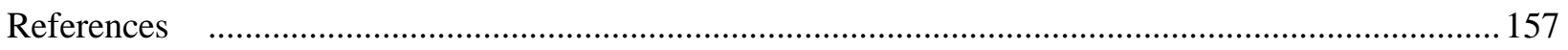




\section{List of Tables}

Table 2-1: Categories of IDX-solar assisted heat pump system.................... 25

Table 2-2: $\quad$ Summary of various types of solar assisted heat pump system for different studies in different location around the

world.

Table 3-1: Physical properties and design parameters used in solving the mathematical model.

Table 3-2: $\quad$ IAM coefficients for four different PV cell type (Soto et al, 2006)............. 55

Table 3-3: Average refractive index of some cover material (John and William, 2006).... 55

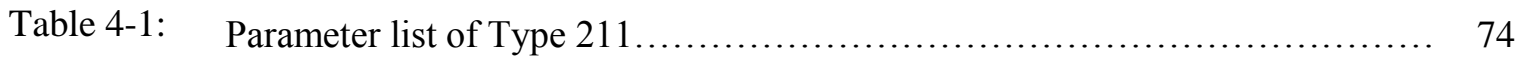

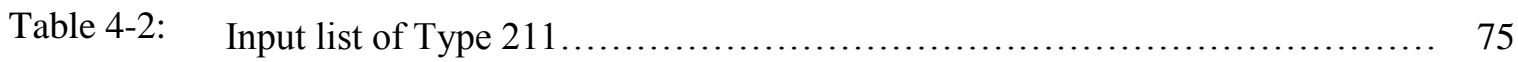

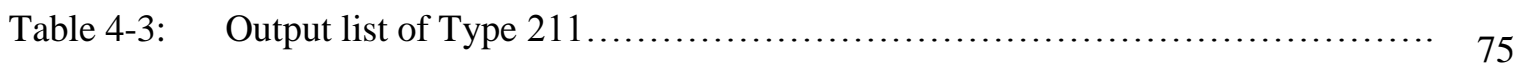

Table 5-1: Annual electricity cost credit from PV/T production...................... 100

Table 5-2: $\quad$ Analysis results for selected Canadian regions........................... 101

Table 6-1: Different operation options of the ASHP for the Test hut facility.............. 111

Table 6-2: $\quad$ Duct system size for coupling BIPV/T and ASHP for test hut facility.......... 120 


\section{List of Figures}

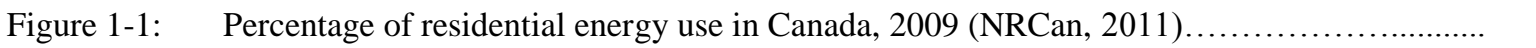

Figure 2-1: The change of ratio $\eta_{\mathrm{T}} / \eta_{\text {ref }}$ with operating temperature for typical silicon based PV module

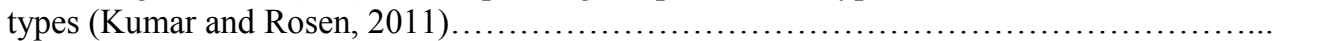

Figure 2-2: $\quad$ The comparison between PV, PV/T and solar thermal systems (Husan and Sumathy, 2010)

Figure 2-3: Classification of BIPV/T system (Agrawal and Tiwari, 2010).....

Figure 2-4: Cooling and heating mode of ventilated PV operation (Chow, 2010)

Figure 2-5: $\quad$ Test results of the compared system PV/water, PV/ air, PV/free and PV/insul regarding their PV operation temperature for the corresponding incident solar radiation $\mathrm{G}$, ambient temperature Ta and wind speed Vw (Tripanagnostopoulos et al., 2002).

Figure 2-6: The electrical efficiency $\eta_{\mathrm{el}}$ of the compared systems PV/water, PV/ air, PV/free and $\mathrm{PV} /$ insul and the thermal efficiency $\eta_{\text {th }}$ of systems PV/water and PV/ air for the corresponding operating conditions in Fig. 8 (Tripanagnostopoulos et al., 2002)

Figure 2-7: The effect of air mass flow rate in PV/T system on the electrical and thermal efficiencies (Bambrook and Sproul, 2012).

Figure 2-8: $\quad$ Cross section view of the PV evaporator model (Liu et al., 2009)....................

Figure 2-9: $\quad$ A schematic diagram of the PV-SAHP system (Chow et al., 2010b)................... 20

Figure 2-10: $\quad$ Schematic diagram of basic SAHP system types (Day and Karayiannis, 1994)......

Figure 2-11: These heat pump units are located near the building exhaust vents to utilize any waste heat (Stevens et al., 2013).

Figure 2-12: Air based solar assisted heat pump using roof as low efficiency solar collector (Loveday, 1992).

Figure 3-1: Cross section for energy balance of the PV/T collector with air flow pattern over elemental area bdx.

Figure 3-2: Configuration of the PV/T systems.

Figure 3-3: $\quad$ Electricity and thermal energy production of the heating season for different arrangements $\left(\mathrm{N}_{\mathrm{S}} \times \mathrm{N}_{\mathrm{R}}\right), \mathrm{d}=38 \mathrm{~mm}$ and total air mass flow rate of $1.2 \mathrm{~kg} / \mathrm{s}$ (a) per row (b) for the whole array.

Figure 3-4: Total thermal energy production for the whole arrangements $\left(\mathrm{N}_{S} \times \mathrm{N}_{\mathrm{R}}\right)$ with different depths and mass flow rates.

Figure 3-5: Total electricity and thermal energy production of heating season for different arrangements with different duct depth, total air mass flow rate of $1.2 \mathrm{~kg} / \mathrm{s}$

Figure 3-6: Overall PV/T system efficiency for different configurations with different depths, total air mass flow rate of $1.2 \mathrm{~kg} / \mathrm{s}$.

Figure 3-7: Overall PV/T system efficiency for $5 \times 3$ and $3 \times 5$ arrangements with different depths, total air mass flow rate of $1.2 \mathrm{~kg} / \mathrm{s}$. 
Figure 3-8: Overall PV/T system efficiency with different total mass flow rates and different depths, $5 \times 5$ arrangement.

Figure 3-9: Total thermal energy production recovered from PV/T systems of the heating season for $5 \times 5$ arrangements with different total air mass flow rate and different duct depth.

Figure 3-10: Total electricity production recovered from PV/T systems of the heating season for $5 \times 5$ arrangements with different total air mass flow rate and different duct depth.

Figure 3-11: TRNSYS type's connections creating a model...................................... 51

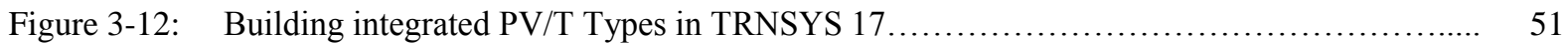

Figure 3-13: A schematic of PV/T system used in Type 566 and Type 567 (TRNSYS17, 2012)......... 52

Figure 3-14: Thermal resistance for energy balance of BIPV/T in TRNSYS (Type 566 and Type 657)... 53

Figure 3-15: IAM as a function of incident angle for King Model and general method (John and William, 2006; Soto et al, 2006).....

Figure 3-16: Thermal interaction between Type 56 and Type 567

Figure 3-17: Hourly variation of a PV panel temperature and its electrial effiicency for a typical day in winter (January, 21st).

Figure 3-18: The effect of panel position in a row on total electricity production for a typical Winter day (January 21st) with different flow rate, with $\mathrm{d}=76.2 \mathrm{~mm}$ ( 3 in).

Figure 3-19: The effect of panel position in a row on PV panel electrcial efficiency for a typical Winter day (January 21st) with different flow rate, with $\mathrm{d}=76.2 \mathrm{~mm}(3 \mathrm{in})$..

Figure 3-20: The effect of panel position in a row on PV panel temperature for a typical Winter day (January 21st) with different flow rate, with $\mathrm{d}=76.2 \mathrm{~mm}$ (3 in).

Figure 3-21: Effect of mass flow rate on the instantaneous useful thermal energy obtained from BIPV/T system and (Tout - Tin) of air (winter 12 noon), January $21^{\text {st }}$.

Figure 3-22: Hourly variation of PV/T collectors surfaces temperatures (cover surface, PV surface, upper air channel surface, lower air channel surface, and back surface), outlet air temperature and zone temperature for (a) $0.4 \mathrm{~kg} / \mathrm{s}$ (b) $0.1 \mathrm{~kg} / \mathrm{s}$.

Figure 4-1: Cross section for energy balance of TBIPV/T collector............................... 68

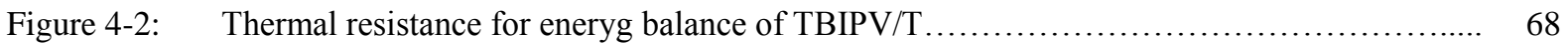

Figure 4-3: $\quad$ Energy balance on air element in PV/T collector (John and William, 2006)................ 70

Figure 4-4: The effect of packing factor on (a) useful thermal energy (b) electricity generation from $\mathrm{TBIPV} / \mathrm{T}$ collector in a typical winter day (Jan. 21) ..................................

Figure 4-5: Hourly variation of the TBIPV/T collector thermal efficiency and overall efficiency with

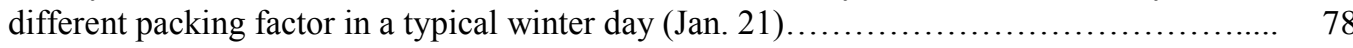

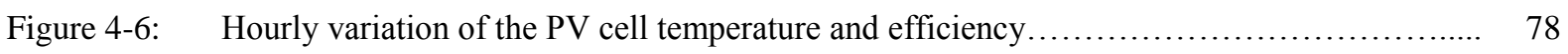

Figure 4-7: Hourly variation of total incident solar radiation on a tilted surface in Toronto during a typical day in winter and summer. 
Figure 4-8: Hourly variation of useful thermal energy obtained from TBIPV/T collector with different packing factors in a typical day in winter (Jan. 21) and a typical day in summer (Aug.16.....

Figure 4-9: Hourly variation of electrical energy obtained from TBIPV/T collector with different packing factors in a typical day in winter (Jan. 21) and a typical day in summer (Aug. 16)...

Figure 4-10: Hourly variation of glass transmittance and radiation incident angle for different TBIPV/T collector slopes in (a) winter and (b) summer.

Figure 4-11: Effect of collector slope on useful thermal energy obtained from TBIPV/T system for winter and summer typical days

Figure 5-1: $\quad$ South side of twin houses.

Figure 5-2: The overall methodology used in this study

Figure 5-3: ASHP heating COP vs outdoor temperature at Archetype Sustainable House in Toronto during winter test (Dec. 1, 2010-Feb. 9, 2011) (Safa et al., 2015a)

Figure 5-4: Seasonal heating COP for different depths and different row air mass flow rates:

(a) $\mathrm{N}_{\mathrm{S}}=5$, (b) $\mathrm{N}_{\mathrm{S}}=4$, and (c) $\mathrm{N}_{\mathrm{S}}=3$.

Figure 5-5: Hourly total available radiation on tilted surface and total thermal energy obtained from roof integrated $5 \times 5 \mathrm{PV} / \mathrm{T}$ array for the archetype sustainable house in Toronto area.....

Figure 5-6: Monthly electricity generated by the BIPV/T system in Archetype Sustainable House in Toronto.

Figure 5-7: Monthly GHG emission credit from the PV/T array used in ASH......

Figure 5-8: $\quad$ ASHP daily cumulative electricity consumption for heating season with and without PV/T system.

Figure 5-9: Monthly GHG emission due to electricity consumed by ASHP.

Figure 5-10: Monthly net GHG emission due to the net of electricity demand by ASHP + PVT and produced by $\mathrm{PV} / \mathrm{T}$ array. 96

Figure 5-11: Price of electricity in Ontario since September 1st, 2013 for winter and summer. 98

Figure 5-12: Monthly electricity cost for the ASHP working alone and combined with PV/T system......

Figure 5-13: Monthly net electricity cost credit from PV/T electricity production based on hourly TOU price.

Figure 6-1: Test hut facility at TRCA (a) south view (b) north view....

Figure 6-2: $3 \mathrm{D}$ test hut facility model in TRNSYS3d SketchUp

Figure 6-3: Heating/Cooling load of Test hut facility.

Figure 6-4: Heating/Cooling load of House A (Safa et al., 2015a)

Figure 6-5: Heating load of House A and test hut facility versus outdoor temperature for Toronto. 108

Figure 6-6: Schematic of BIPV/T system integrated with ASHP and thermal energy storage system..... 
Figure 6-7: A photo for the outdoor box unit of the air source heat pump for (BIPV/T + ASHP) project at TRCA.

Figure 6-8: Annual fan power consumption for $5 \times 5$ BIPV/T system with different total air flow rate

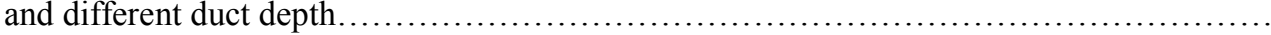

Figure 6-9: Annual net electrical energy produced from the PV/T array when part of electricity used by

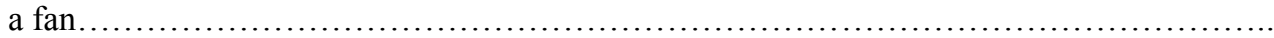

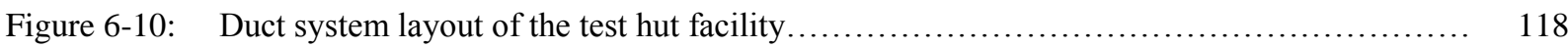

Figure 6-11: Illustration of test hut facility with BIPVT system combined with ASHP and TES.......... 119 


\section{Nomenclature}

b duct width, $\mathrm{m}$

C heat capacity of air, $\mathrm{J} / \mathrm{kg} \cdot \mathrm{K}$

d duct depth, $m$

$\mathrm{D}_{\mathrm{h}} \quad$ hydraulic diameter, $\mathrm{m}$

E electricity generated by PV panel, W

Eff $_{\mathrm{I}}$ radiation efficiency modifier for the PV panel, $\mathrm{m}^{2} / \mathrm{W}$

$\mathrm{Eff}_{\mathrm{T}}$ temperature efficiency modifier for $\mathrm{PV}$ panel, $1 /{ }^{\circ} \mathrm{C}$

$f \quad$ friction factor, (-)

g acceleration due to gravity, $\mathrm{m} / \mathrm{s}^{2}$

$\mathrm{h}_{\text {air }}$ convection heat transfer coefficient of the air flowing in the duct, $\mathrm{W} / \mathrm{m}^{2} \cdot \mathrm{K}$

$\mathrm{h}_{\mathrm{c}} \quad$ convection heat transfer coefficient due to wind effect, $\mathrm{W} / \mathrm{m}^{2} \cdot \mathrm{K}$

$\mathrm{h}_{r_{1-2}}$ radiation heat transfer coefficient between the top and bottom surfaces of the PV/T air channel, $\mathrm{W} / \mathrm{m}^{2} \cdot \mathrm{K}$

HP head pressure, $\mathrm{m}$

$\mathrm{h}_{\mathrm{rs}} \quad$ radiation heat transfer coefficient between the top surface of the PV panel and the $\mathrm{sky}, \mathrm{W} / \mathrm{m}^{2} \cdot \mathrm{K}$

$\mathrm{I}_{\mathrm{T}} \quad$ total incident solar radiation on a tilted surface, $\mathrm{W} / \mathrm{m}^{2}$

$\mathrm{I}_{\mathrm{T}, \mathrm{b}} \quad$ beam radiation on a tilted surface, $\mathrm{W} / \mathrm{m}^{2}$

$\mathrm{I}_{\mathrm{T}, \mathrm{g}} \quad$ ground reflected diffuse radiation on tilted surface, $\mathrm{W} / \mathrm{m}^{2}$

$\mathrm{I}_{\text {ref }}$ the reference solar radiation at standard test conditions at which the PV efficiency is given, $\mathrm{W} / \mathrm{m}^{2}$

$\mathrm{I}_{\mathrm{T}, \mathrm{sd}} \quad$ sky diffuse radiation on tilted surface, $\mathrm{W} / \mathrm{m}^{2}$

$K \quad$ glazing extinction coefficient, $1 / \mathrm{m}$

$k \quad$ pressure loss coefficient, (-)

$k_{\text {air }} \quad$ thermal conductivity of air flowing in the $\mathrm{PV} / \mathrm{T}$ duct, $\mathrm{W} / \mathrm{m} \cdot \mathrm{K}$

$\mathrm{k}_{\text {back }}$ thermal conductivity of the PV panel back surface, $\mathrm{W} / \mathrm{m} \cdot \mathrm{K}$

$\mathrm{k}_{\mathrm{ins}} \quad$ thermal conductivity of the PV/T back insulation, $\mathrm{W} / \mathrm{m} \cdot \mathrm{K}$

L $\quad$ PV panel length, $m$

$l \quad$ thickness of transparent cover, $\mathrm{m}$ 


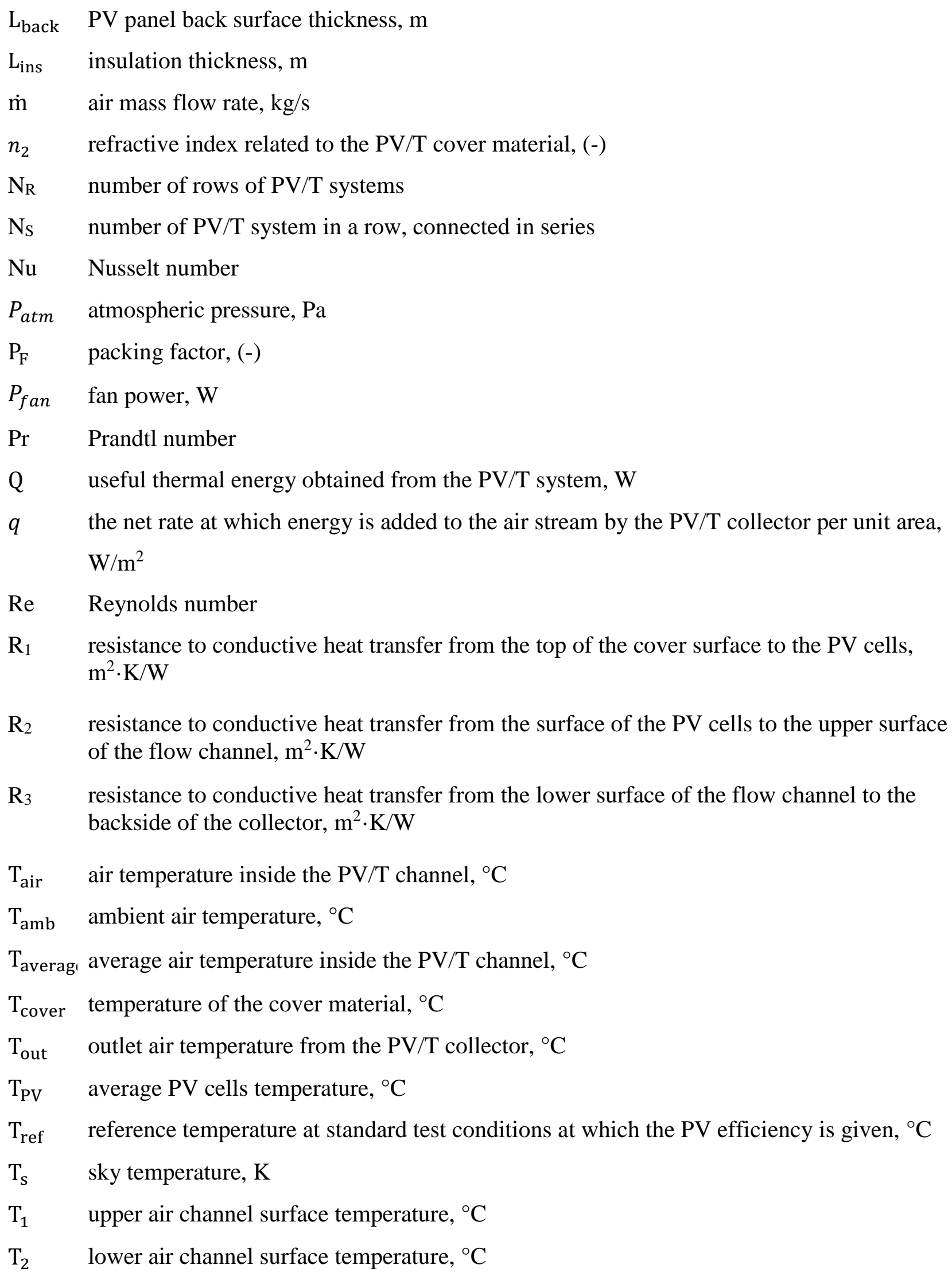


$\mathrm{T}_{3} \quad$ the temperature of the back surface of the $\mathrm{PV} / \mathrm{T}$ collector (zone air / collector interface), ${ }^{\circ} \mathrm{C}$

$\mathrm{U}_{\text {back }}$ heat loss coefficient of the PV panel back surface, $\mathrm{W} / \mathrm{m}^{2} \cdot \mathrm{K}$

$\mathrm{U}_{\text {ins }}$ heat loss coefficient of the PV/T insulation, $\mathrm{W} / \mathrm{m}^{2} \cdot \mathrm{K}$

$\mathrm{U}_{\text {top }} \quad$ top heat loss coefficient from PV panel (combined conduction and convection resistance), $\mathrm{W} / \mathrm{m}^{2} \cdot \mathrm{K}$

$\mathrm{V}$ air velocity, $\mathrm{m} / \mathrm{s}$

$\mathrm{V}_{\mathrm{w}} \quad$ wind velocity, $\mathrm{m} / \mathrm{s}$

$\dot{V} \quad$ volumetric air flow, $\mathrm{m}^{3} / \mathrm{s}$

\section{Greek symbols}

$\alpha_{a b s} \quad$ absorptivity of lower air-channel surface

$\alpha_{\mathrm{PV}} \quad$ absorptivity of solar cells

$\alpha_{\mathrm{T}} \quad$ absorptivity of the back surface material behind the PV panel

$\beta \quad$ collector slope, degree

$\Delta P \quad$ pressure drop along the $\mathrm{PV} / \mathrm{T}$ system, $\mathrm{Pa}$

$\epsilon \quad$ emissivity of the collector top surface for long wave radiation exchanges with the sky

$\epsilon_{1} \quad$ emissivity of the upper surface of the air channel

$\epsilon_{2} \quad$ emissivity of the lower surface of the air channel

$\varepsilon \quad$ surface roughness, $\mathrm{mm}$

$\eta_{\text {Fan }} \quad$ fan efficiency

$\eta_{\text {motor }}$ motor efficiency of the fan

$\eta_{\text {panel }} \quad$ PV panel efficiency

$\eta_{\mathrm{PV} / \mathrm{T}} \quad$ overall efficiency (electricity + thermal) of the PV/T system

$\eta_{\text {ref }}$ reference efficiency of PV panel at standards test conditions

$\theta \quad$ incidence angle of solar radiation, angle between the beam of light and the normal to the panel surface, degree

$\theta_{g} \quad$ equivalent effective incidence angle for ground reflected radiation component, degree

$\theta_{r} \quad$ angle of refraction, degree

$\theta_{s d}$ equivalent effective incidence angle for sky diffuse radiation component, degree

$\mu \quad$ air dynamic viscosity, $\mathrm{kg} / \mathrm{m} \cdot \mathrm{s}$

$\rho_{\text {air }} \quad$ air density, $\mathrm{kg} / \mathrm{m}^{3}$ 
$\sigma \quad$ Stefan Boltzmann constant, $\mathrm{W} / \mathrm{m}^{2} \cdot \mathrm{K}^{4}$

$\tau \alpha \quad$ transmittance-absorption of glazing system

$\tau_{\mathrm{g}} \quad$ transmissivity of glass 


\section{Abbreviations}

\begin{tabular}{|c|c|}
\hline AHU & Air Handling Unit \\
\hline ASH & Archetype Sustainable House \\
\hline ASHP & Air Source Heat Pump \\
\hline ASHRAE & American Society of Heating, Refrigerating and Air-Conditioning Engineers \\
\hline $\mathrm{a}-\mathrm{Si}$ & Amorphous Silicon Cells \\
\hline $\mathrm{BIPV} / \mathrm{T}$ & Building Integrated Photovoltaic/Thermal collector \\
\hline CFD & Computational Fluid Dynamic \\
\hline CFM & Cubic Feet Per Minute \\
\hline $\mathrm{COP}$ & Coefficient of Performance \\
\hline $\mathrm{c}-\mathrm{Si}$ & Mono-crystalline Silicon Cells \\
\hline DHW & Domestic Hot Water \\
\hline DX-SAHP & Direct Expansion Solar Assisted Heat Pump \\
\hline $\mathrm{GHG}$ & Greenhouse Gas \\
\hline GSHP & Ground Source Heat Pump \\
\hline HVAC & Heating, Ventilation and Air Conditioning \\
\hline HX & Heat Exchanger \\
\hline IAM & Incident Angle Modifier \\
\hline $\mathrm{ICF}$ & Insulated Concrete Forms \\
\hline IDX-SAHP & Indirect Expansion Solar Assisted Heat Pump \\
\hline IEA & International Energy Agency \\
\hline $\mathrm{kWh}$ & Kilowatt Hour \\
\hline $\mathrm{LOC}$ & Location of the PV/T Collector \\
\hline
\end{tabular}




\begin{tabular}{|c|c|}
\hline mc-Si & Multi-crystalline Silicon Cells \\
\hline NRCan & Natural Resources Canada \\
\hline NZEH & Net Zero Energy House \\
\hline PCM & Phase Change Material \\
\hline pc-Si & Polycrystalline Silicon Cells \\
\hline PV & Photovoltaic \\
\hline $\mathrm{PV} / \mathrm{T}$ & Photovoltaic-Thermal \\
\hline $\mathrm{PV} /$ free & PV Module with Both its Surfaces Free to Ambient \\
\hline PV/air & PV/T System with Air Duct under the PV Module \\
\hline $\mathrm{PV} /$ water & PV/T System with Thermal Unit of Water Circulation Through a Heat Exchanger \\
\hline PV/insulation & PV Module with Thermal Insulation on its Back \\
\hline SAHP & Solar Assisted Heat Pump \\
\hline SIP & Structurally Insulated Panel \\
\hline TBIPV & Transparent Backing Building Integrated Photovoltaics \\
\hline $\mathrm{TBIPV} / \mathrm{T}$ & Transparent Building Integrated Photovoltaic-Thermal \\
\hline TD & Thermal Demand \\
\hline TES & Thermal Energy Storage \\
\hline TESS & Thermal Energy System Specialists Libraries \\
\hline TMY2 & Typical Meteorological Weather Data \\
\hline TOU & Time-of-Use \\
\hline TRCA & Toronto and Region Conservation Authority \\
\hline TRNSYS & TRanNsient SYstem Simulation Program \\
\hline VC-ASHP & Variable Capacity Air Source Heat Pump \\
\hline
\end{tabular}


VCS

WSHP

Ventilated Concrete Slab

Water Source Heat Pump 


\section{Chapter 1: Introduction}

Canada is considered to be one of the coldest countries in the world. The majority parts of the country experience long winter season. Consequently, total end-use energy consumption of Canada is high. Canadians paid $\$ 42.68$ billion on family home annual energy demand. The residential sector in Canada consumes energy mostly for space heating (63\%) and domestic hot water (17\%) as shown in Figure 1-1. Over the last two decades, the energy used in dwellings has changed slightly. Natural gas and electricity have become dominant and together accounted for $87 \%$ of all residential energy use in 2009 (NRCan, 2011).

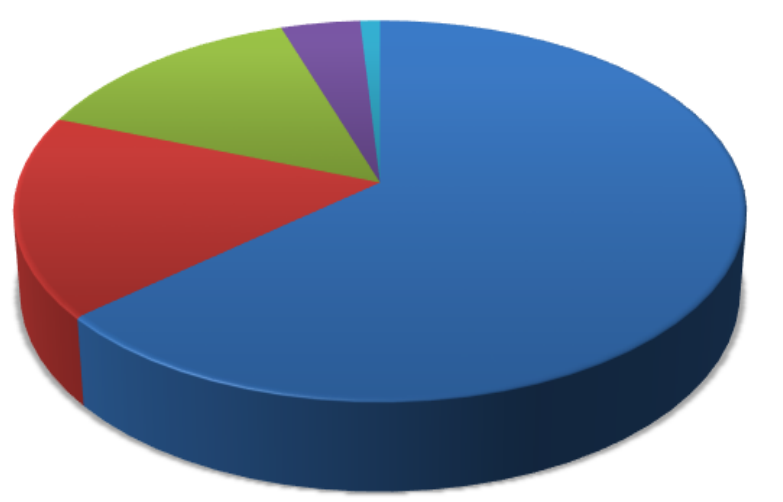

$\square$ Space heating $63 \%$

घ Water heating $17 \%$

$\square$ Appliances $14 \%$

- Lighting $4 \%$

$\square$ Space cooling $1 \%$

Figure 1-1: Percentage of residential energy use in Canada, 2009 (NRCan, 2011)

The increase in energy demand requires seeking alternative ways for energy supply. In addition, rapid intensive utilization of fossil fuels results in shortage of their resources and increasing energy costs and environmental pollution (Ibrahim et al., 2011). The energy required by the world is estimated to increase by 50\% from 2005 to 2030 . This increase is affected by population expansion and financial improvement (Pareto and Pareto, 2008)

Renewable energy, in contrast to fossil fuel, will never be depleted. In addition, renewable energy is clean and sustainable. The main renewable energy resources are direct solar energy, wind, tidal/wave, hydro and biomass. Sunlight, known as solar energy, can be used in lighting and heating buildings. All sources of renewable energy can be used to generate electricity, which is 
essential to our modern life (Needham, 2009). Therefore, many studies have been made on different types of renewable energy, which principally depend on solar energy. The renewable energy technologies in current use supply approximately $13.3 \%$ of the world's energy demands (Husan and Sumathy, 2010).

Solar radiation can be converted into thermal energy by using solar thermal collectors in different thermal systems applications; for examples, stoves, dryers, water heaters, and purification equipment. The typical range of efficiencies for solar thermal systems is about $40 \%-60 \%$. Also, direct conversion of solar radiation into electricity could be achieved by using what is called Photovoltaic (PV) panels (Kumar and Rosen, 2011). The market for Photovoltaic panels (PV) grew by $30 \%$ in 2014, compared to the previous year (Clara, 2014). Over the last decade, countries and companies have been investing in solar energy, with an average growth rate of $135 \%$ from 2003 to 2010. Consequently, the cost of solar energy has been decreasing. It is expected that the cost of solar thermal energy, depending on solar intensity and location, will drop from a range of \$61/MWh to \$122/MWh in 2007 to \$22/MWh to \$44/MWh in 2050 (IEA, 2011).

Not all absorbed solar radiation by solar cells is converted into electricity. This results in an increase in the PV panel temperature, which decreases the electrical efficiency of PV panels. An interesting combination of a plain PV with a solar thermal collector leads to what is known as Solar Photovoltaic/Thermal (PV/T) technology. The hybrid PV/T systems produce thermal energy and electricity as total output energy. The hybrid PV/T reduces the PV modules temperature by circulating fluid, resulting in better electrical efficiency (Tripanagnostopoulos et al., 2002). Thermal energy from a PV/T or a solar collector could be used for space heating, domestic water heating, and even for air conditioning. To allow for continuous and sufficient space heating, a $\mathrm{PV} / \mathrm{T}$ system or a solar collector system can be combined with a heat pump. The common potential advantage to the solar collector and the heat pump performance is to depress the collector temperature and boost the heat pump evaporator temperature. Consequently, the performance of both subsystems could be enhanced. The need for such integration approach comes from the fact that it is important to make sure the source temperature of the heat pump does not drop too low, particularly below freezing temperature. The integrated arrangement is known as Solar Assisted Heat Pump (SAHP) or Solar Thermal Heat Pump (STHP). 
Bertsch and Groll (2008) showed that functionally such system was able to operate at temperature between $-30{ }^{\circ} \mathrm{C}$ and $10{ }^{\circ} \mathrm{C}$, resulting in $\mathrm{COP}$ of 2.1 at $-30^{\circ} \mathrm{C}$. Umezu and Suma (1984) have shown that energy saving up to $15 \%$ could be achieved using a variable capacity compressor two-stage air source heat pump. In Toronto, Canada, Safa et al. (2011a; 2011b; 2015a) have performed experimental and energy simulation of a two-stage variable capacity air source heat pump (ASHP) at the Archetype Sustainable House using TRNSYS 16. The results showed that the

peak electricity demand and heating output were $8.30 \mathrm{~kW}$ and $13.17 \mathrm{~kW}$, respectively, which occurred during the second stage operation in heating mode when the ambient temperature was $-22.11^{\circ} \mathrm{C}$, with a considerable lower COP of 1.58 . This performance can be further enhanced by feeding low-grade thermal energy into the ASHP. This can be achieved by generating warm air from the building-integrated photovoltaic/thermal (BIPV/T) collector. Candanedo and Athienitis (2011) showed that the typical range of air temperature leaving the $\mathrm{BIPV} / \mathrm{T}$ is $0^{\circ} \mathrm{C}-20^{\circ} \mathrm{C}\left(32^{\circ} \mathrm{F}-\right.$ $68^{\circ} \mathrm{F}$ ), which depends on several factors, such as flow rate, outdoor temperature, and solar radiation. The exit temperatures of the BIPV/T system are relatively low to be applied directly, but it could be used as the source of a heat pump.

\subsection{Motivation}

There are several challenges with respect to heating systems using single-stage air-source heat pumps (ASHP) in cold climates, such as Canada, especially when outdoor temperatures are below $0^{\circ} \mathrm{C}$. One of the main problems of air-source heat pumps at very low ambient temperatures is the decrease of heat output and COP. The coefficient of performance (COP) is used to measure the heat pump efficiency, defined as the ratio of the amount of energy provided by the heat pump to electrical energy consumed. The COP of a heat pump becomes better with increasing evaporating temperature (for fixed condensing temperature). In cold days, especially when the outdoor temperature decreases below $0^{\circ} \mathrm{C}$, the performance of the heat pump decreases. Research showed that a two-stage heat pump could perform better in harsh weather.

An air based SAHP can cover the heating load in cold climate if a heat pump is properly connected with a solar system. The preheated air from a solar collector could be a source for traditional air source heat pump. However, what is the best PV/T system arrangement? What are the operation modes that enable the combined system to work for both heating and cooling seasons? What are the updated technological approaches for experimentation and evaluating such 
configuration? In addition, the duct system design of the combined systems, i.e., connecting a BIPV/T system with a heat pump, is another challenge.

Air has significant advantages over liquid such as no freezing and leakage issues, however, it has low thermal capacity, low heat transfer and low density, leading to high mass flow rate required for a given application. Most of the developed SAHP systems use liquid as working fluid since it has higher thermal capacity, and it can be used as a medium to store thermal energy in thermal energy storage (TES) when heating is not required. Therefore, in solar heating systems, a thermal storage tank is an important part since it is considered as the source of thermal energy at night or at low solar irradiance intensity.

\subsection{Objectives and thesis outlines}

The main objective of this thesis is to examine the feasibility of coupling a building integrated photovoltaic-thermal (BIPV/T) system with an air source heat pump (ASHP) system for Canadian climate by modeling, simulation, and energy analysis. To investigate the potentials of combining a passive system and dynamic building envelope technologies such as hybrid solar systems, short-term thermal storage, and an air source heat pump to achieve near net-zero annual energy consumption, a full-scale test hut facility was designed to be built at Kortright Centre in Woodbridge, Ontario.

This thesis consists of seven chapters. The detailed objectives of each chapter are listed below:

- Chapter 2: Chapter 2 presents a comprehensive review of PV and PV/T systems and covers the latest design, installation and, possible improvements of solar systems. The details of different solar assisted heat pump systems and their integration with solar system are also provided.

- Chapter 3: A PV/T model was developed to conduct comprehensive analysis to estimate the effect of PV/T system arrangement and different design parameters on the thermal and electrical performance. This chapter also examines an existing component Type for opaque BIPV/T system in TRNSYS simulation program. The selected BIPV/T TRNSYS Type was modified based on the developed energy model of the PV/T collector. 
- Chapter 4: A detailed thermal and electrical energy generation model of a transparent backing building integrated photovoltaic/thermal (TBIPV/T) system was developed. The developed model was applied as a new Type in TRNSYS simulation program named Type 211 . A sensitivity analysis was done to investigate the effect of different parameters on the TBIPV/T system performance.

- Chapter 5: A TRNSYS model was developed to integrate a photovoltaic/thermal collector (PV/T) in a roof and coupled with an air source heat pump in an Archetype Sustainable House (House A). The model was used to estimate the potential benefits and improvements in the heat pump performance by direct coupling of $\mathrm{BIPV} / \mathrm{T}+\mathrm{ASHP}$ and to address the saving in the electricity cost and energy as well as greenhouse gas (GHG) emission reduction potentials.

- Chapter 6: Chapter 6 presents a detailed description of the full-scale test hut facility. A TRNSYS model for the test hut facility was created. Design of the required duct system for delivering air from the BIPV/T array to the heat pump are also presented with different operation modes. Pressure drop along the BIPV/T system and through the duct system was conducted. The energy required by a fan for driving air flow is an important information in order to select a proper fan.

- Chapter 7: Chapter 7 summarises the main results and conclusions of this dissertation and introduces the recommendations for future work. 


\section{Chapter 2: Literature Review}

This chapter reviews and presents the studies and investigations of solar systems and their combination with heat pumps. The main objectives in the literature review are:

i. Review the fundamentals of PV, solar thermal collectors, PV/T collectors and their classification.

ii. Discuss and cover the design and installation, performance, potential improvements, and the cost assessment of the solar systems.

iii. Provide details of different solar assisted heat pump system configurations and the types of integration with solar system; identifying the most promising system for a cold climate.

iv. Review the areas of applications.

\subsection{The concept of PV systems}

A French physicist, Edmond Becquerel, was the first scientist who recorded the photoelectric effect in 1839. He discovered that some materials create small quantities of electric current when they are presented to light. In 1876, Adam and Day studied the effect of photovoltaics in solid material and made the first PV cell with efficiency of 1-2\% (Kumar and Rosen, 2011). In a photovoltaic cell, only photons with enough high-energy can discharge an electron for an electric circuit. A photovoltaic arrangement consists of a number of panels, which are made by a number of solar cells connected together. The amount of electricity produced by an array depends on the total area of the array (Knier, 2014).

The electrical efficiency of a photovoltaic module is affected by several parameters, mainly, the intensity of solar radiation, the packing factor, and the average temperature of the panel. High solar irradiance means a large number of electrons to be released; accordingly, more current from the cell is obtained. Increasing the packing factor (the area of a PV panel covered by solar cells) results in more current per unit collector area. However, high intensity of solar irradiance and packing factor increase the solar cells temperatures, which affect the module efficiency negatively; in other words, PV efficiency declines as PV module temperature increases, because high PV cells temperatures reduce the voltage significantly comparing with a very small increase in the current (Kumar and Rosen, 2011). Figure 2-1 shows the effect of operating 
temperature of the PV panel on the efficiency ratio $\left(\eta_{\mathrm{T}} / \eta_{\text {ref }}\right) ; \eta_{\text {ref }}$ is the efficiency at a reference temperature and $\eta_{T}$ is the efficiency at a temperature T. It is shown from Figure 2-1 that when the operating temperature increases from $300 \mathrm{~K}$ to $330 \mathrm{~K}$, the PV module efficiency of (m-Si) module decreases by $15 \%$, while the module efficiency for a thin film module goes down by only $5 \%$. The PV modules utilize just a slight amount of the received solar radiation to generate electrical power. Therefore, the maximum electrical efficiency is between 5\% and 20\% (Charalambous et al., 2007). The rest of the radiation is waste heat in the cell, which increases PV cell temperature (Husan and Sumathy, 2010). It is necessary to cool the photovoltaic modules by some means to enhance the efficiency and to convert the waste heat into useful thermal energy for different applications.

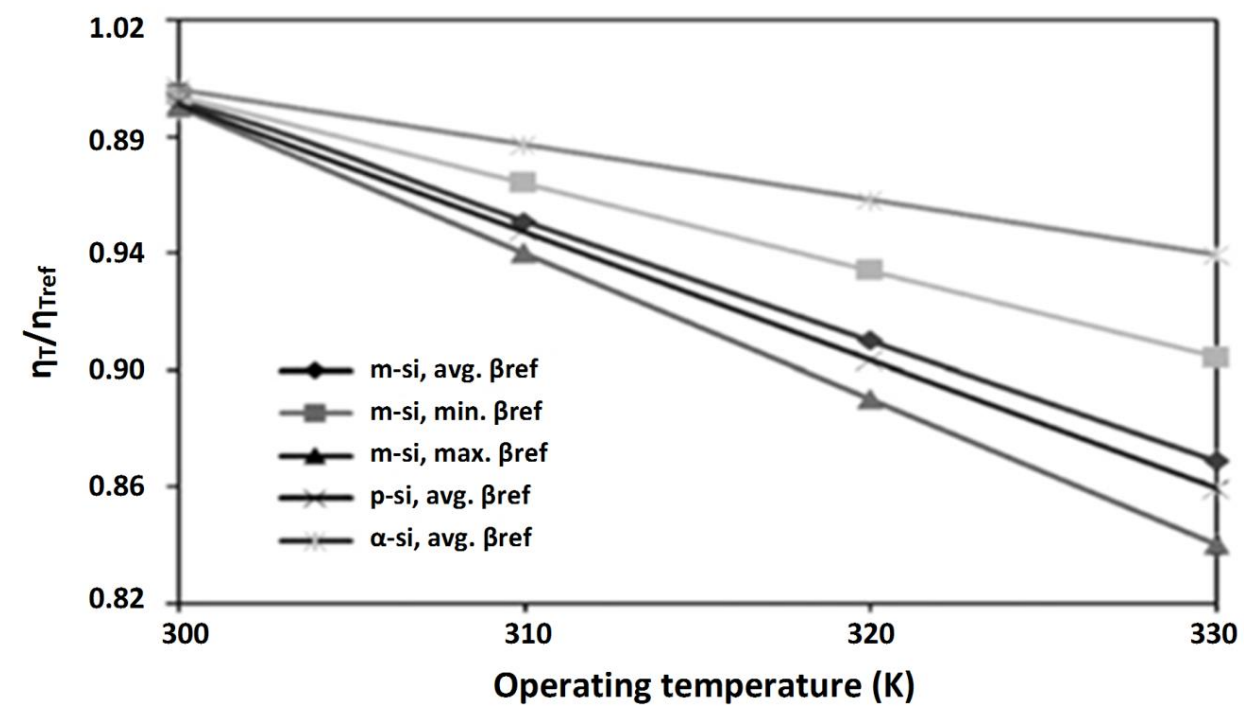

Figure 2-1: The change of ratio $\eta_{\mathrm{T}} / \eta_{\text {ref }}$ with operating temperature for typical silicon based PV module types (Kumar and Rosen, 2011)

\subsection{Solar thermal collectors}

Solar thermal collectors produce thermal energy from solar radiation. A fluid such as air, water, glycol, oil, etc., is used as a working fluid which acts as heat transfer medium. The thermal energy from the solar collector could be used in space heating and domestic hot water (DHW) production or could be stored in thermal energy storage for various purposes. The solar thermal collector can be classified according to the fluid type: liquid type and air type. In addition, solar thermal collectors are classified as either non-concentration types such as flat plate or concentration types such as compound parabolic concentrators. 
For applications, which require working fluid temperature less than $100^{\circ} \mathrm{C}$, stationary solar collectors are used while for high temperatures $\left(250-2500^{\circ} \mathrm{C}\right)$, concentrating solar collectors with a tracking device are used. The main parts of the flat plate collector are: clear cover, the absorber, frame, and insulation. The heart of the collector is the absorber, which is usually manufactured from copper or aluminum. The backside of the collector is insulated well to reduce heat losses. To ensure a good heat transfer to the working fluid, a number of tubes are fixed under the absorber plate. These types of solar collectors are suitable for applications of low and medium temperature and the efficiency range is $40 \%$ to $60 \%$. Solar thermal efficiency decreases dramatically for temperatures over $60^{\circ} \mathrm{C}$. Many studies give the priority to combining flat plate collectors with photovoltaic systems to utilize the waste heat as thermal energy in different applications (Kumar and Rosen, 2011). The International Energy Agency (IEA) showed in its annual Solar Heat Worldwide report that the solar thermal collector market in Canada and USA had a growth of $16.1 \%$ between 2009 and 2010; the newly installed collector areas were $129,418 \mathrm{~m}^{2}$ and $199,491 \mathrm{~m}^{2}$ in 2009 and 2010 respectively (Mauthner and Weiss, 2014).

\subsection{Hybrid Photovoltaic-Thermal (PV/T) collector}

The concept of PV/T started in the 1970s (Kumar and Rosen, 2011). A solar collector is combined with a photovoltaic panel to extract excess heat to reduce the cell temperature, leading to improve the electrical efficiency. Such integration is called hybrid Photovoltaic-Thermal (PV/T)

collector (Tripanaganostopoulos, 2007). In this system, solar radiation is converted into electricity and thermal energy at the same time. The continuous cooling of PV modules guarantees electrical efficiency at acceptable levels. Therefore, the best alternative to the PV system is PV/T (see Fig. 2-2). The priority of PV/T solar systems is the electricity production. Therefore, it is better to reduce the $\mathrm{PV}$ cells temperature to maximize electrical efficiency, which requires the $\mathrm{PV} / \mathrm{T}$ to work within limited range of low temperatures. The collected heat from the PV/T system could be utilized for different applications: preheating air or water, space heating and, ventilation in dwelling. 


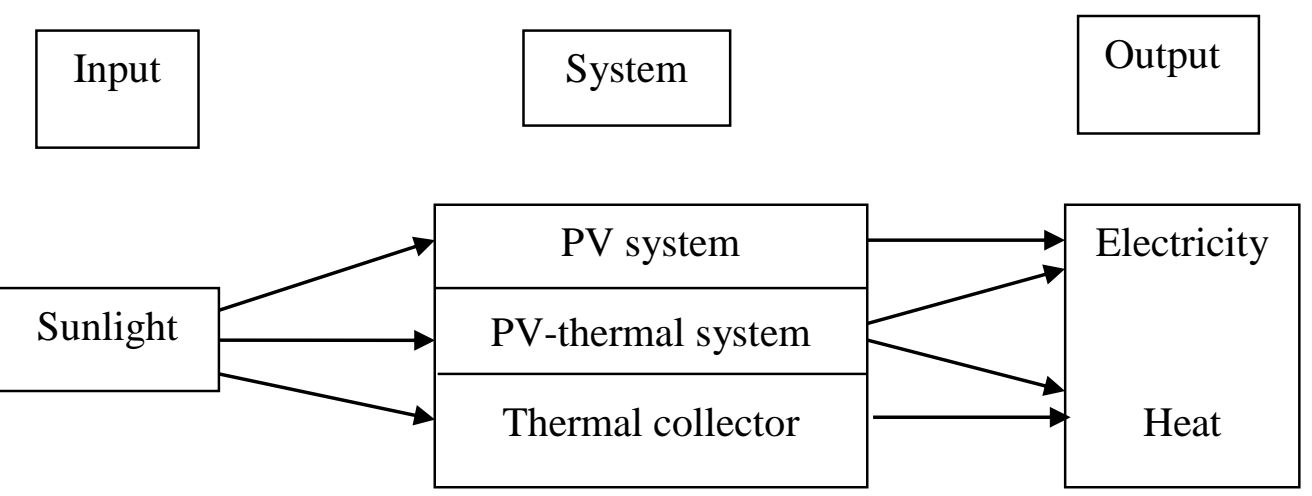

Figure 2-2: The comparison between PV, PV/T and solar thermal systems (Husan and Sumathy, 2010)

The recent PV/T technology expansion is a consequence of the concern of the environmental issues, rising energy prices, and reduction in fossil fuel resources. The attractive features and advantages of PV/T are listed in review studies (Husan and Sumathy, 2010; Kumar and Rosen, 2011):

1- The system of integrated photovoltaic-thermal collectors works as a dual function system, which provides electricity and heat at the same time.

2- The combined efficiency of a photovoltaic module with solar thermal collector is higher than two separate systems of a similar area. For example, two collectors with area $1 \mathrm{~m}^{2}$ each, one is a solar thermal collector to produce domestic hot water and the other is a photovoltaic module to produce electricity; they generated $520 \mathrm{kWh}$ of thermal energy and $72 \mathrm{kWh}$ of electricity, respectively. The hybrid PV/T of $2 \mathrm{~m}^{2}$ produced thermal energy and electricity of $720 \mathrm{kWh}$ and $132 \mathrm{kWh}$, respectively, i.e., 44\% more energy than two independent systems.

3- The payback time for PV/T is less than that for individual systems. For example, an economic study in Greece showed that a PV/T system decreased the payback time by 10 years for c-Si modules and by 6 years for a-Si modules.

4- The PV/T system is considered noiseless and clean technology since it does not create any poisonous and dangerous waste or radioactive material, and it reduces greenhouse gas emissions.

Photovoltaic/thermal systems are usually installed on rooftops or in large fields coupled with the electrical power grid. Users can save in utility bills if part of the power load is covered by 
grid-connected PV/T systems. At the same time, the produced heat from PV/T can be used to meet the space heating for residential and commercial buildings.

\subsection{Classification of $\mathrm{PV} / \mathrm{T}$}

A PV/T system could be flat plate or concentrating (Charalambous et al., 2007), glazed or unglazed (Husan and Sumathy, 2010). In glazed type, a cover of the glass is placed over the absorber in order to minimize the heat losses to ambient. Glazed collectors produce higher annual thermal energy, which is suitable for medium and high temperature applications. On the other hand, glazed collectors can be damaged due to hot spots, which reduce electrical yield.

Photovoltaic solar thermal collectors can be classified according to the working fluid as PV/T liquid collector and PV/T air collector (Kumar and Rosen, 2011) with different channel shapes and flow patterns for both collector types. It is also possible to use both liquid and air in the same collector. Choosing the working fluid must be done carefully, taking into consideration the solar radiation in the local area, heat capacity of the fluid, design configuration, and the range of temperature. For indoor space air-conditioning and agriculture applications, air is preferred as a working fluid.

There are limitations in using the liquid PV/T system such as additional costs for thermal pipes, heat exchanger elements, and pumps for water circulation as well as freezing problems in low temperature regions (Husan and Sumathy, 2010). Therefore, the solar systems designed for very cold climates like Canada need to use anti-freezing fluids such as propylene-glycol/water mixture (Harrison et al., 2004).

The principle of using air as the working fluid in photovoltaic-thermal systems is the same as in solar air collector heaters. PV/T air collectors are inexpensive comparing to water-based $\mathrm{PV} / \mathrm{T}$ collectors since few modifications are needed to convert the conventional PV to PV/T with air as a working fluid. The main applications of PV/T air collectors are providing hot air for space heating and drying of agriculture products (Husan and Sumathy, 2010).

Using air as a working fluid has advantages and disadvantages over water (Husan and Sumathy, 2010; Kumar and Rosen, 2011):

Advantages: 
1- Avoiding problems of freezing and boiling of the collector fluid.

2- Less concern about corrosion.

3- There is no concern about damage due to leakage.

4- Safety for high pressure is not needed.

Disadvantages:

1- Low heat capacity and thermal conductivity results in low heat transfer rate.

2- Higher volumetric flow rate is needed due to low density.

\subsection{Building integrated PV/T: design and installations}

The term BIPV/T signifies the photovoltaic-thermal array, which is incorporated within the building structure. The system combines the building roof or facade, photovoltaic cells and thermal collector all in one product instead of installing each one individually. So, it effectively replaces the conventional building material and becomes cheaper than having several separate products. It could be part of the building elements from the beginning of the building construction, principally the roof and the facade. In this case, its function is not only producing electricity, but also for other purposes (Montoro et al., 2012):

- Noise protection

- Producing thermal energy for space heating in winter or producing hot water

- Providing natural ventilation in PV glazing design, which could be used for heating or cooling purposes

- One-way mirroring visual cover

- Superior attractive view to the conventional PV and solar collectors

- Providing building protection: waterproof and windproof

In the early 1990's, the integration of photovoltaic technology within the building envelope BIPV/T started commercially in new and renovated buildings (Eiffert and Kiss, 2000). The BIPV/T system could be categorized into opaque type and semi-transparent type; the opaque type could be installed on roofs and walls while the semi-transparent type may be integrated into windows as well as on roofs and walls (Agrawal and Tiwari, 2010). Figure 2-3 shows a diagram of classification of the BIPV/T system. When a cavity behind the PV is used, ventilation by the circulation of air cools the PV array. The cavity behind the PV arrangement could be used for 
cooling or heating the building according to the vent opening arrangements, as shown in Fig. 2-4 (Chow, 2010). For heating purpose, the PV is considered as PV/T.

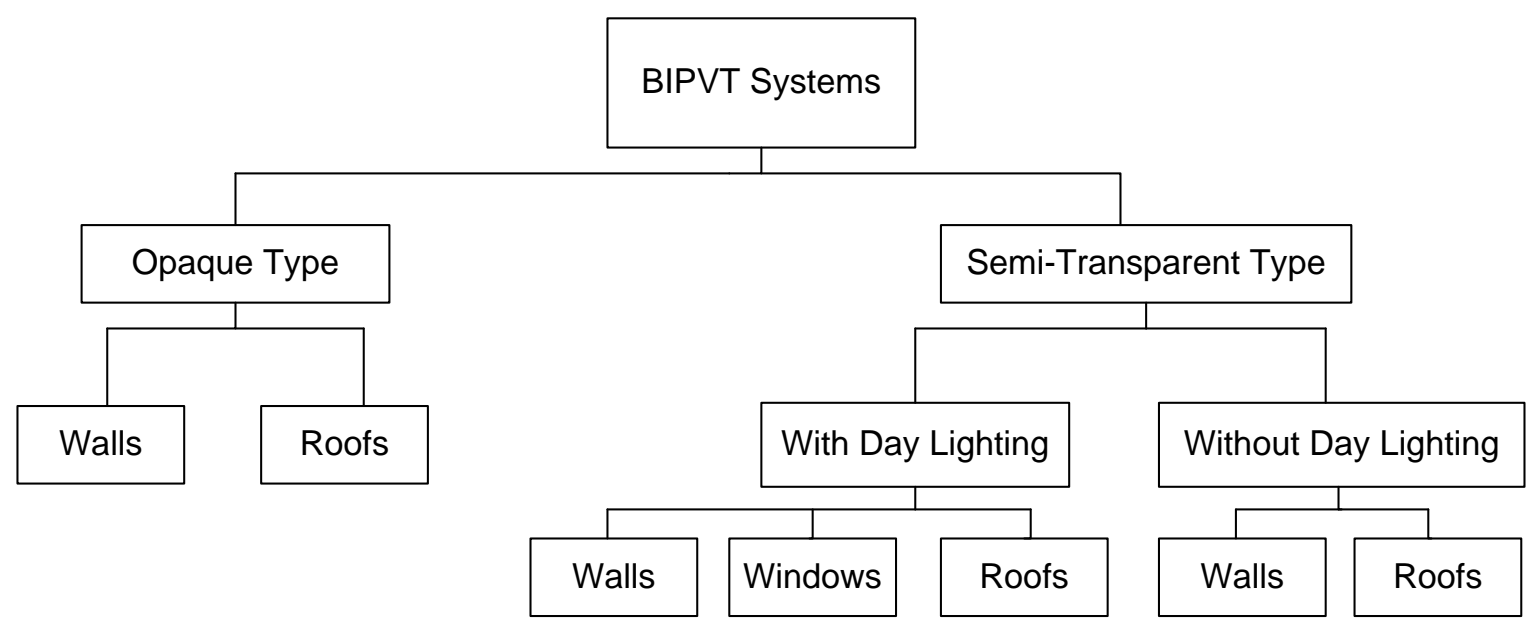

Figure 2-3: Classification of BIPV/T system (Agrawal and Tiwari, 2010)

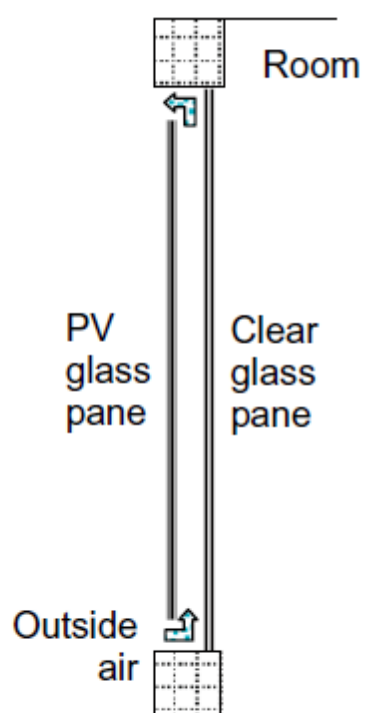

(a) Cooling mode

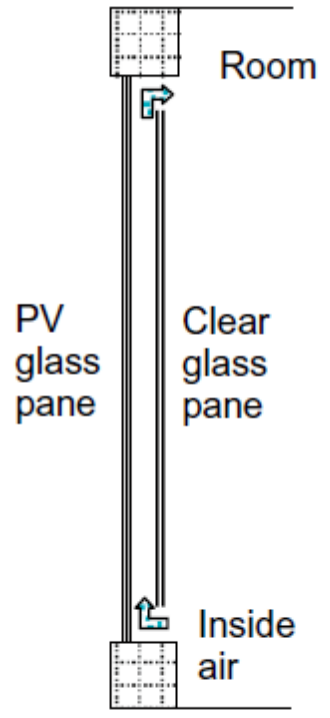

(b) Heating mode

Figure 2-4: Cooling and heating mode of ventilated PV operation (Chow, 2010)

It is known that the amount of solar irradiance, ambient temperature and the latitude affect the thermal gain and efficiencies of photovoltaic-thermal collectors. Also, the way in which the $\mathrm{PV} / \mathrm{T}$ system is integrated within the building plays a major role in maximizing the utilization of 
solar energy. The electrical production is influenced by the photovoltaic inclined angle, the direction of the installation, the distance between panels (density of position), length of the panels and panel shading by other panels or surrounding buildings (Hwang et al., 2012).

Vats and Tiwari (2007) determined the temperature of a room utilizing a building integrated PV/T system. Comparative analysis was done between semi-transparent BIPV/T and opaque BIPV/T integrated to the roof and façade of the room, with and without airflow by forced convection through a duct behind the PV array. The study demonstrated that the maximum room temperature reached was $22^{\circ} \mathrm{C}$ for a semi-transparent type roof without an air duct. The minimum rise in room temperature occurred for opaque façade with air duct.

Guiavarch and Peuportier (2006) developed a dynamic simulation tool to study the performance of a BIPV/T system for two building types: single-family home and social apartment building. The study examined the influence of the integration type on the efficiency of a PV collector for two different climates. The PV integrated roof without ventilation and with preheating resulted in the overall efficiency of $14 \%$ and $20 \%$ respectively for the family house. For the social building, the overall efficiencies were $13 \%$ and $14 \%$ for configurations without ventilation and with ventilation respectively.

Hachem et al. (2012) have presented a study of potential generation of electrical and thermal energy from BIPV/T systems integrated with different roof designs of two-story housing units. They investigated the effect of different roof designs on energy performance to maximize electricity and heat generation to achieve net zero energy status. The results showed that some roof shape designs could increase electricity generation potential of the BIPV/T system by up to $30 \%$. Certain orientations of the BIPV/T systems extended the peak time of electrical energy production for up to 3 hours.

Athienitis (2007) demonstrated the proposal of a net-zero energy solar house with BIPV/T systems, water-air geothermal heat pump, and in-floor heating system. The main structures of the energy system were two 272-litre water tanks, the duct design for the BIPV/T roof, and the solar roof. The design emphasized on the architectural point of view for integration of solar thermal collectors on the roof, electrical power and thermal energy obtained from BIPV/T systems, and the advanced passive solar design. Chen et al. (2010) showed that construction of the BIPV/T roof 
in the factory (combining all parts of the PV/T system: the frame with duct, the metal roof and the insulation) provides a suitable environment in site construction during winter and harsh weather. The BIPV/T roof was transported to the site for assembly of the house.

\subsection{Performance analysis and improvement of BIPV/T system}

To assess the performance of an integrated photovoltaic-thermal system, experimental and theoretical studies should be done on the building envelope, taking into consideration the heating and cooling load, building type, location and other aspects. The overall efficiency of the BIPV/T is estimated by considering the total energy (thermal and electrical) obtained from the PV/T collector. In building applications, the working fluid is selected according to the weather data of the location. For locations with high outdoor temperature and high solar radiation intensity, liquid is preferred since it has higher thermal capacity than that of air. For location with low ambient temperature and solar input, air could be used as the working fluid to have a more efficient system (Tripanagnostopoulos et al., 2002).

The basic attention in photovoltaic-thermal systems is the cooling process done by the circulating fluid. Therefore, studying the fluid flow and conducting thermal analysis within the PV/T system is important. Infield et al. (2004) presented thermal analysis to estimate the performance of heat gains and losses of a ventilated PV façade in a public library building in Mataro, Spain. The performance of the façade was characterized by the factors of radiation gain via transmission, ventilation to the interior, and heat loss by transmission from the building inside to ambient and ventilation. The performance factors of the façade were represented in terms of irradiance and measured temperatures. The results showed that the average façade thermal efficiency was $13 \%$ for ventilation velocity of $0.3 \mathrm{~m} / \mathrm{s}$, giving a thermal gain of $70 \mathrm{kWh} / \mathrm{m}^{2}$ from façade ventilation in winter. The study concluded that the external wind direction had an effect on ventilation flow. An appropriate air entrance and exit designs were recommended.

Numerical and experimental investigations for fluid flow and heat transfer characteristics in the roofing and façade of BIPV/T have been done (Sandberg and Moshfegh, 1996, 1998, 2002; Moshfegh and Sandberg, 1996, 1998). In these analyses, different design considerations have been

included such as inclination angle of the roof panels, position of the solar cell module, and aspect 
ratio of air cavity. Reporting that maximum flow rate is limited by the balance between buoyancy and friction forces.

Tonui and Tripanaganostopoulos (2007a) experimentally studied the improvement of a typical PV/T solar collector with two modification techniques: using thin flat metallic sheet (TMS) and installing fins in the air path. The test was conducted under forced and free airflow circulation with airflow rates and velocities of $60 \mathrm{~m}^{3} / \mathrm{h}, 12.5 \mathrm{~m}^{3} / \mathrm{h}$ and $0.25 \mathrm{~m} / \mathrm{s}, 0.06 \mathrm{~m} / \mathrm{s}$ respectively. The thermal efficiency increased by $12 \%$ for TMS and by $20 \%$ fin system. The improvement in thermal efficiency was supported by air circulation, which reduced the PV module temperature by $5^{\circ} \mathrm{C}$.

An experimental study was carried out in Greece (Tripanagnostopoulos et al., 2002) to test $\mathrm{PV} / \mathrm{T}$ models under real weather conditions. The PV/T system modules were designed to use water and air as working fluids to remove heat, i.e., PV/water and PV/air systems. Since the heat removal by both air and water decrease PV module temperature, the electrical efficiency of the PV systems increases. Therefore, it is useful to compare the results with (PV/free) system and (PV/insulation) system. The comparisons of the PV/water, PV/air, PV/free, and PV/insulation systems are shown in Figures 2-5 and 2-6. In this experiment, pc-Si cell based PV systems were used for all systems while operating under identical weather conditions. 


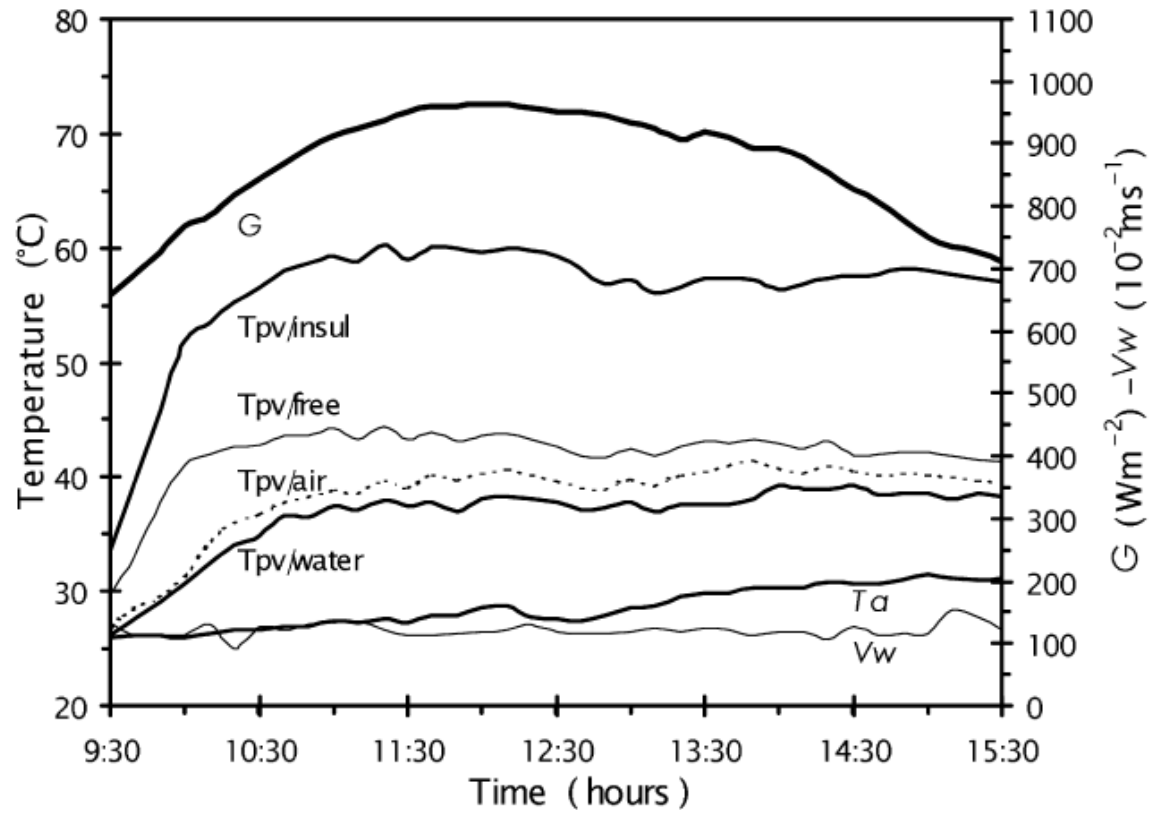

Figure 2-5: Test results of the compared system PV/water, PV/ air, PV/free and PV/insul regarding their PV operation temperature for the corresponding incident solar radiation $G$, ambient temperature Ta and wind speed Vw (Tripanagnostopoulos et al., 2002)

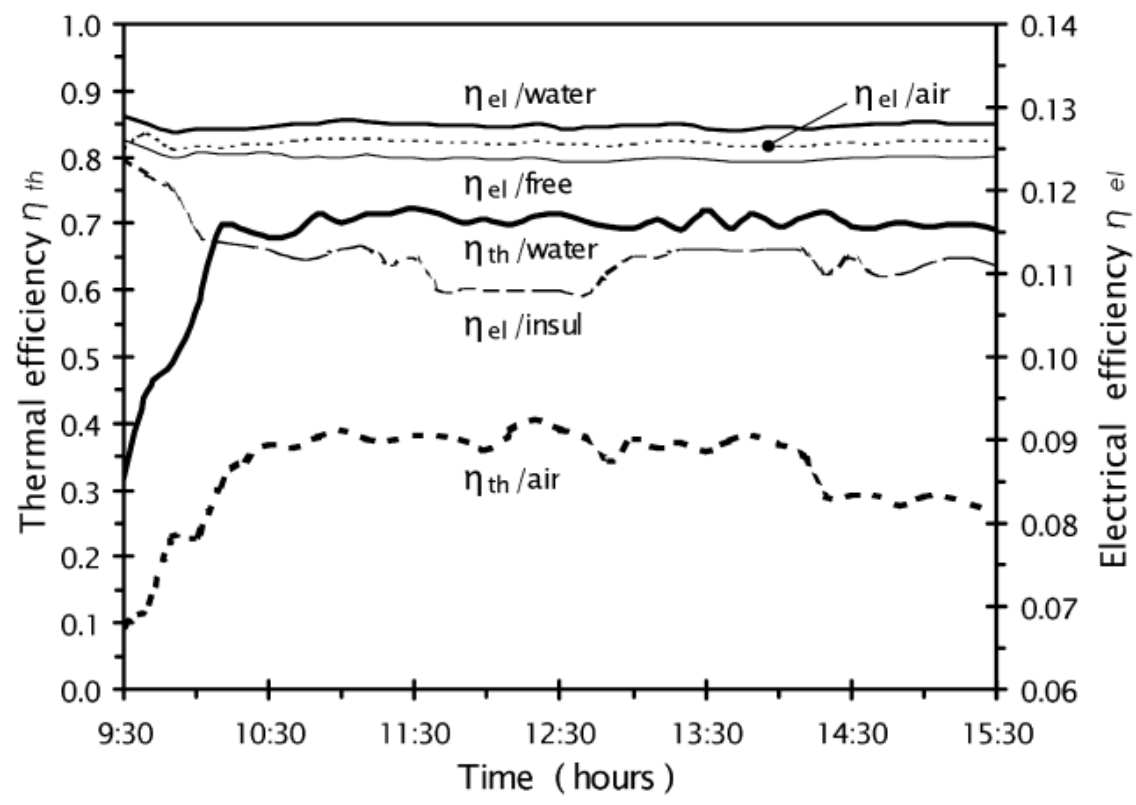

Figure 2-6: The electrical efficiency $\eta_{\mathrm{el}}$ of the compared systems PV/water, PV/ air, PV/free and $\mathrm{PV} /$ insul and the thermal efficiency $\eta_{\text {th }}$ of systems PV/water and PV/ air for the corresponding operating conditions in Fig. 8 (Tripanagnostopoulos et al., 2002) 
It is clear from Figure 2-5 that the PV temperature was lower with water circulation than that with air circulation. The PV operating temperatures were $\left(T_{p v / \text { water }} \approx 38^{\circ} \mathrm{C}\right)$ and $\left(T_{p v / a i r} \approx\right.$ $\left.41{ }^{\circ} \mathrm{C}\right)$ for using water and air, respectively, because the water temperature $\left(T_{w} \approx 20^{\circ} \mathrm{C}\right)$ from the mains was less than ambient temperature $\left(T_{a} \approx 29^{\circ} \mathrm{C}\right)$. Also, the module temperature of $\mathrm{PV} /$ free $\operatorname{panel}\left(T_{p v / f r e e} \approx 43^{\circ} \mathrm{C}\right)$ was less than the module temperature of PV/insulation panel $\left(T_{p v / \text { insul }} \approx\right.$ $55^{\circ} \mathrm{C}$ ) because of the radiation and convection thermal losses from both sides of the PV/free panels.

Decreasing the module temperature affects both electrical efficiency, $\eta_{e l}$ and thermal efficiency, $\eta_{t h}$ as shown in Figure 2-6. The electrical efficiency of PV/insulation $\left(\eta_{e l / \text { insul }}=\right.$ $0.113)$ was lower than those of the other systems $\left(\eta_{e l / \text { free }}=0.124, \eta_{e l / a i r}=0.126, \eta_{e l / w a t e r}=\right.$ 0.128 ) because of the high temperature rise of this system. The electrical efficiency results were obtained for experiments under mild conditions $\left(T_{a}=29^{\circ} \mathrm{C}\right)$. The experiments were also performed under lower and higher ambient temperatures. The water and air systems can supply adequate thermal energy, but the outlet temperature of the fluid must be restricted to avoid overheating the PV.

For a better perception of the flow inside the cavity of BIPV/T, Zogou and Stapountzis (2012) performed flow visualization experiments combined with CFD simulation for airflow inside a testing device for PV/T façade building application. For free and forced flow inside the $\mathrm{PV} / \mathrm{T}$ channel, the average value of the wall heat transfer coefficient was calculated by CFD simulation. It was found that the heat transfer characteristics and flow rate value had an effect on the performance of the PV/T system.

Increasing the mass flow rate of the circulating fluid increases the thermal and overall efficiencies of Building Integrated Photovoltaic Thermal (BIPV/T) systems. The higher mass flow rate in the PV/T system, the better heat transfer between the fluid and the PV panel; but up to a specific mass flow rate, the thermal and overall efficiencies change slightly. Further increase in mass flow rate is considered as cost and energy consumption (Charalambous et al., 2007; Daghigh et al., 2011). Bergene and Lovvik (1995) presented a mathematical model of a liquid PV/T system. They studied the effect of flow rate on both thermal and electrical efficiencies with a geometric ratio (the ratio of distance between tubes to tube diameter) range of 1-10. They found that system 
efficiency increased by only $1 \%$ when the flow rate was raised from 0.001 to $0.075 \mathrm{~kg} / \mathrm{s}$, suggesting that the critical value of the mass flow rate was $0.001 \mathrm{~kg} / \mathrm{s}$, i.e., no advantage to increase it any more.

Bambrook and Sproul (2012) examined the relation between the heat gain and the rise in temperature to obtain the suitable design of an air-based PV/T system for residential application used for Sydney climate. A TRNSYS simulation analysis was conducted to investigate the thermal and electrical performances for the best experimental design of the PV/T system. The results revealed that there were saving in the generated electricity from the PV/T array when the airflow rate was $0.03-0.05 \mathrm{~kg} / \mathrm{s}$. This was made by using large ducts to minimize the pressure loss and selecting a fan that produced high airflow rates at low input power. For a typical sunny day in winter, when airflow rate was increased, thermal and electrical efficiencies increased in the range of $28-55 \%$ and 10.6-12.2\% respectively. Figure 2-7 shows the effect of airflow rate on the electrical and thermal efficiencies for this experimental.

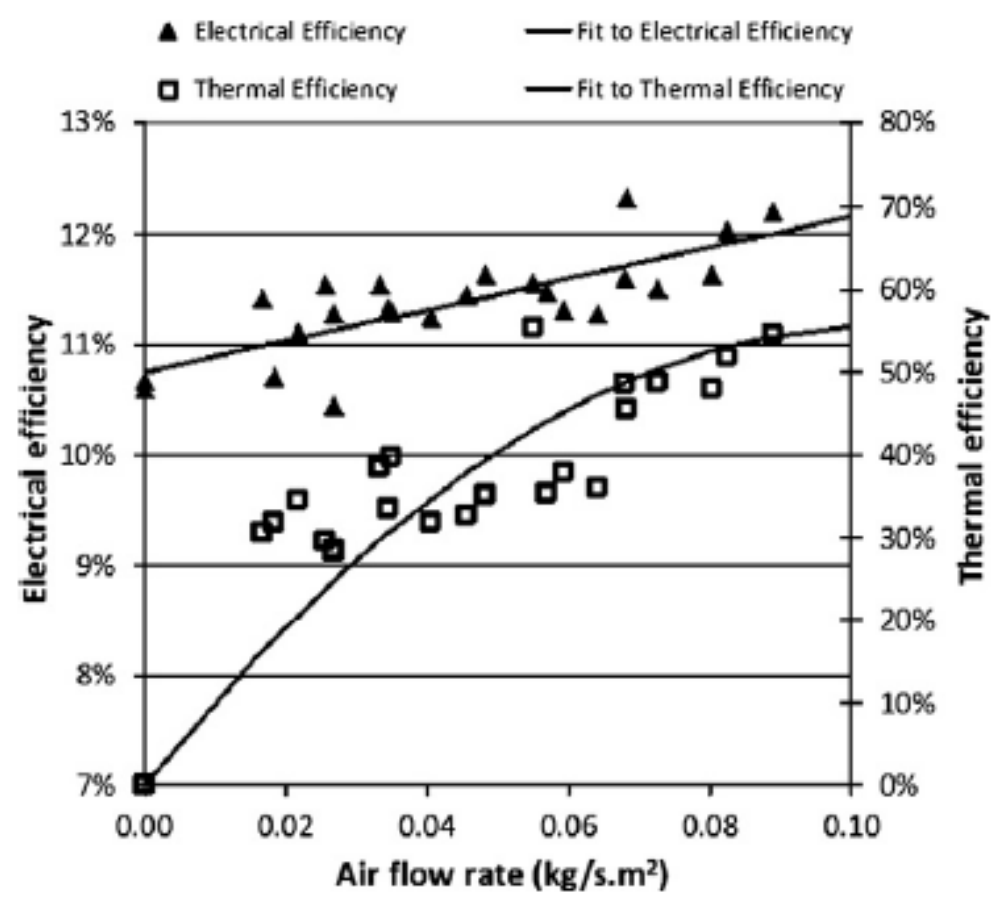

Figure 2-7: The effect of air mass flow rate in PV/T system on the electrical and thermal efficiencies (Bambrook and Sproul, 2012)

Candanedo et al. (2010) presented a steady state model and a transient model for open loop air based BIPV/T systems. The models were developed based on experimental data taken in a test 
channel placed at Concordia University. The study showed that the transient model, which included thermal effects of PV, provided more stable outlet air temperature; it was in agreement with the experimental results better than steady state model. However, it required longer processing time.

\subsection{Solar heat pump}

In 1955, Sporne and Ambrose began to study the potentials of using solar radiation as a source to enhance and improve heat pump performance (Liang et al., 2011; Tom, 2006). However, this kind of integration needs to control the varying of solar intensity during the day in order to boost the coefficient of performance of the heat. The solar system collects energy at low temperature and it may not work efficiently in direct heating. This energy could be used as a source to the heat pump in winter. In other words, the solar collector system provides energy with temperature above the ambient temperature, leading to improve the COP of the heat pump. Therefore, integrated solar energy system with heat pump is an interesting field of research since it saves energy more than that from each system alone (Badescu, 2002a).

Thermal storage is preferred to be included in the solar heat pump system to avoid the damage effect of non-constant solar radiation intensity (Tom, 2006; Kuang et al., 2003; Bakirci and Yuksel, 2011; Gang et al., 2007). Under this incorporation, the thermal storage is on the higher temperature side for an air-based system and on the lower temperature side for a water-based system. The fluid releases some of the thermal energy in storage tank to be used at night and cloudy days as a source for heat pump. The average solar collector efficiency in heating season could reach a high value of $67.2 \%$ when a thermal storage tank is connected to solar arrays and the water source heat pump by using a closed loop heat exchanger.

\subsection{Solar assisted heat pump system classification}

Solar assisted heat pumps are categorized, based on the integration way between a solar system and a heat pump, into Direct Expansion Solar Assisted Heat Pump (DX-SAHP) (Xu et al., 2006; Li et al., 2007a, 2007b; Kong et al., 2011; Omojaro and Breitkopf, 2013; Ji et al., 2009) and Indirect Expansion Solar Assisted Heat Pump (IDX-SAHP) (Kaygusuz, 2000; Terrell, 1979; Bridgeman and Harrison, 2008). In DX-SAHP, the heat pump and the solar system work together 
as one combined system. According to the connection styles and working concept, IDX-SAHP can be classified into subcategories: series system, parallel system and dual system.

\subsubsection{Direct expansion solar assisted heat pump}

In this type of combination, the solar collector or the photovoltaic panel works together with the heat pump as a combined system. The photovoltaic thermal collector in the SAHP system is called PV evaporator, that means PV evaporator itself is the evaporator of the heat pump (Liang et al., 2011; Liu et al., 2009; Chow et al., 2010b). Figure 2-8 shows a cross sectional view of PV evaporator.

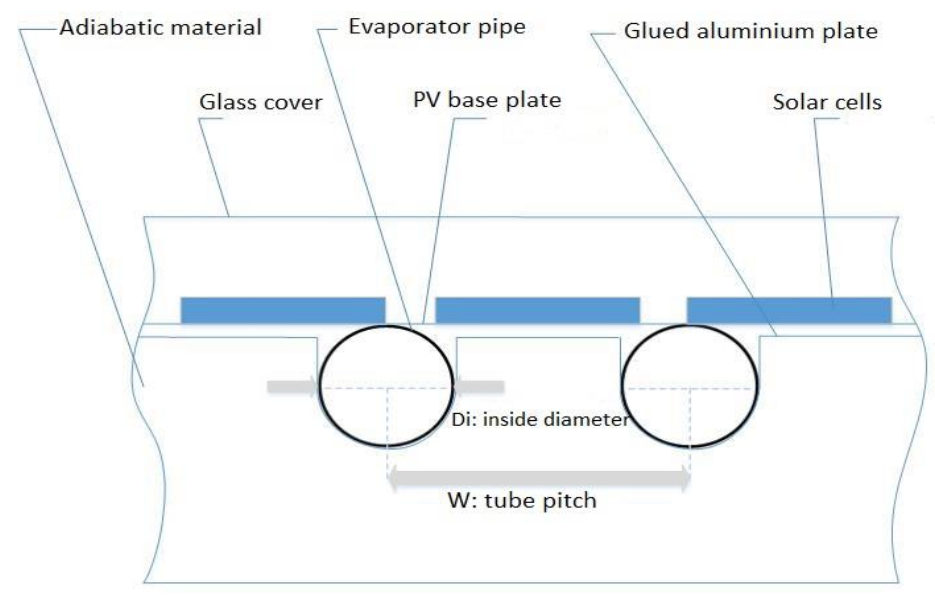

Figure 2-8: Cross section view of the PV evaporator model (Liu et al., 2009)

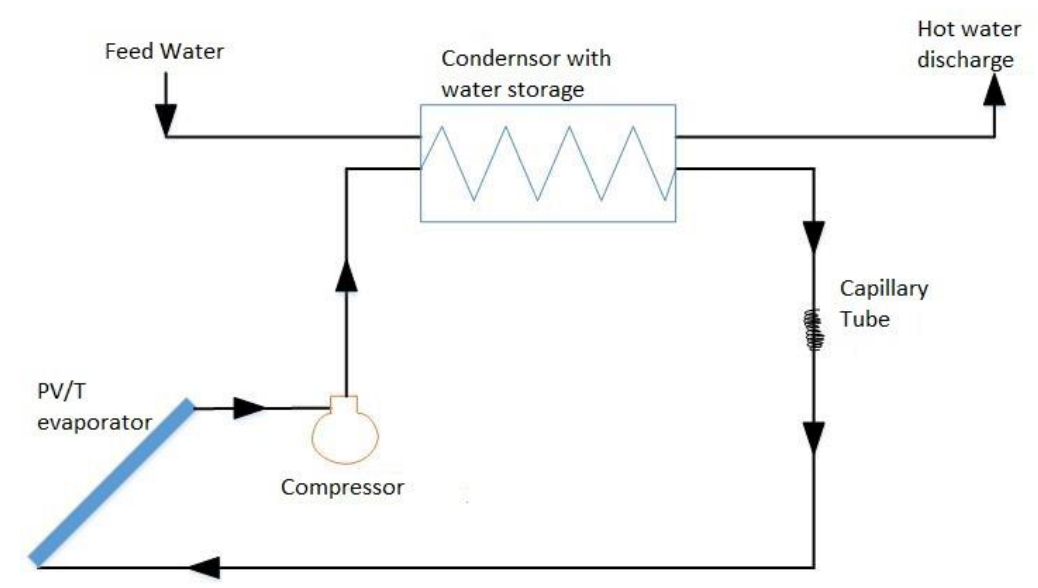

Figure 2-9: A schematic diagram of the PV-SAHP system (Chow et al., 2010b)

The DX-SAHP system generally comprises of a PV evaporator, a compressor, a condenser with a storage water tank, and an expansion valve (see Figure 2-9). A thermal storage tank can 
only be in the condenser side. The coolant fluid used in the evaporator-solar collector is the refrigerant of the heat pump. During the day time, when significant solar radiation is available, the absorbed heat by the PV panels is transferred to the refrigerant which is evaporated. Solar energy absorbed in the collector/evaporator is transferred to the load via the heat pump's condenser. The most common application for DX-SAHP is for water heating applications (Facao and Carvalho, 2014; Chaturvedi et al., 2014); in this case, the condensed working fluid exchanges heat with water in a thermal storage. The solar irradiance is changed with days and seasons, consequently the pressure and temperature of the evaporation vary. Therefore, to prevent two-phase flow entering the compressor and unnecessary superheated refrigerant, a variable frequency compressor is used. This can be accomplished by controlling the expansion valve, which is opened automatically for different compressor frequencies. Chow et al. (2010) activated the simulation DX-SAHP only when the temperature of the evaporation is $10{ }^{\circ} \mathrm{C}$ more than the ambient temperature.

Kuang et al. (2003) conducted theoretical and experimental investigation on DX-SAHP for heating water. They investigated the influence of different parameters (solar intensity, ambient temperature, solar collector area, thermal energy storage size, and compressor capacity) on longterm thermal performance of a proposed system. The outcome of the study was used to optimize the final design of the system and apply a suitable control strategy. The PV-solar collector efficiencies were between $40 \%$ and $60 \%$ and average monthly COP of the heat pump ranged from 4 to 6 . They recommended an auxiliary energy supply in solar assisted heat pump system for best results.

Ji et al. (2008) suggested a mathematical model for photovoltaic heat pump. They conducted experimental and simulation studies to estimate the electrical efficiency, heat pump COP and photovoltaic power generation of the PV modules. A compressor with frequency range of $15-120 \mathrm{~Hz}$ was used. The range of COP was 3.8-8.0 around noon and 6.5 in the morning. During the experimental time, the average ambient temperature was $15.8^{\circ} \mathrm{C}$. The cooling impact of the evaporator reduced the PV cells temperature resulting in average value of the photovoltaic efficiency of $13.7 \%$, which was higher than those without cooling. 


\subsubsection{Indirect expansion solar assisted heat pump}

There are different fundamental arrangements of IDX-SAHP, in which the solar collector is not the evaporator of the heat pump as one combined system. Both the heat pump and the solar collector are combined together, but still are considered as two individual systems (Sterling and Collins, 2012). IDX-SAHP systems are divided into three types; series system, parallel system and dual system. The heat transfer medium is typically antifreeze solution, water or air. In both series system and dual system, the heat pump performance is boosted by the utilization of solar energy. For the parallel system, Figure 2-10(a), a solar system is used to work in parallel with a heat pump, when adequate solar radiation is available, the solar collector system can produce sufficient thermal energy to match the load, but, when there is insufficient solar energy available (during night or cloudy days), a heat pump starts to operate. This type of system delivers to load either from solar radiation or from open-air atmosphere.

The series system is shown in Figure 2-10(b), includes a thermal storage (water tank or rock storage depending on collector fluid) to store the collected solar energy. In such a system type, the collected energy from the solar collector controls the function of the heat pump, that means a heat pump only draws energy from the solar collector (Day and Karayiannis, 1994). If the available solar energy is enough to heat the space, the direct solar heating is made possible by bypassing the heat pump.

The dual source solar assisted heat pump is designed to use two evaporators. The first evaporator (solar-side evaporator) is placed in a solar storage tank (thermal energy collected from the solar collector is stored in this tank), and the second evaporator (air-side evaporator) is placed outdoor in a fan coil unit of the heat pump. The source of heat pump is either the storage tank or the outdoor air, taking the advantage of the source with the highest temperature (Chao et al., 2010) Figure 2-10(c). 


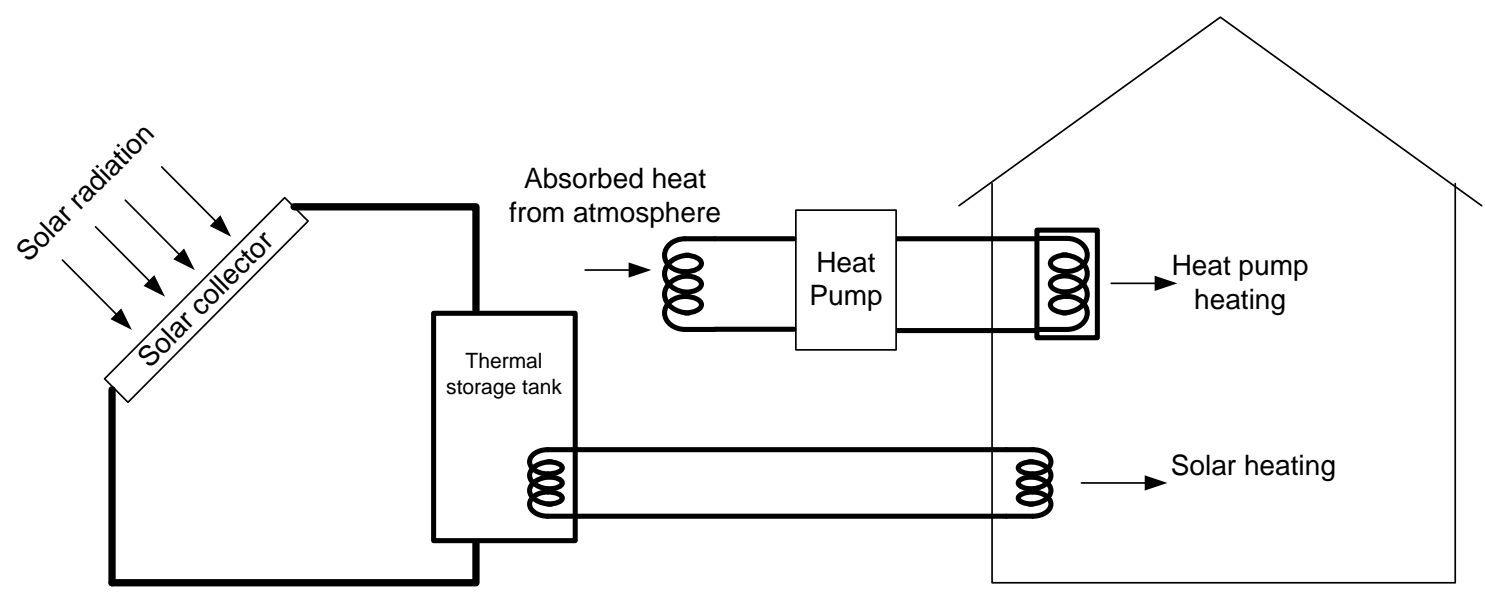

(a) Parallel SAHP configuration

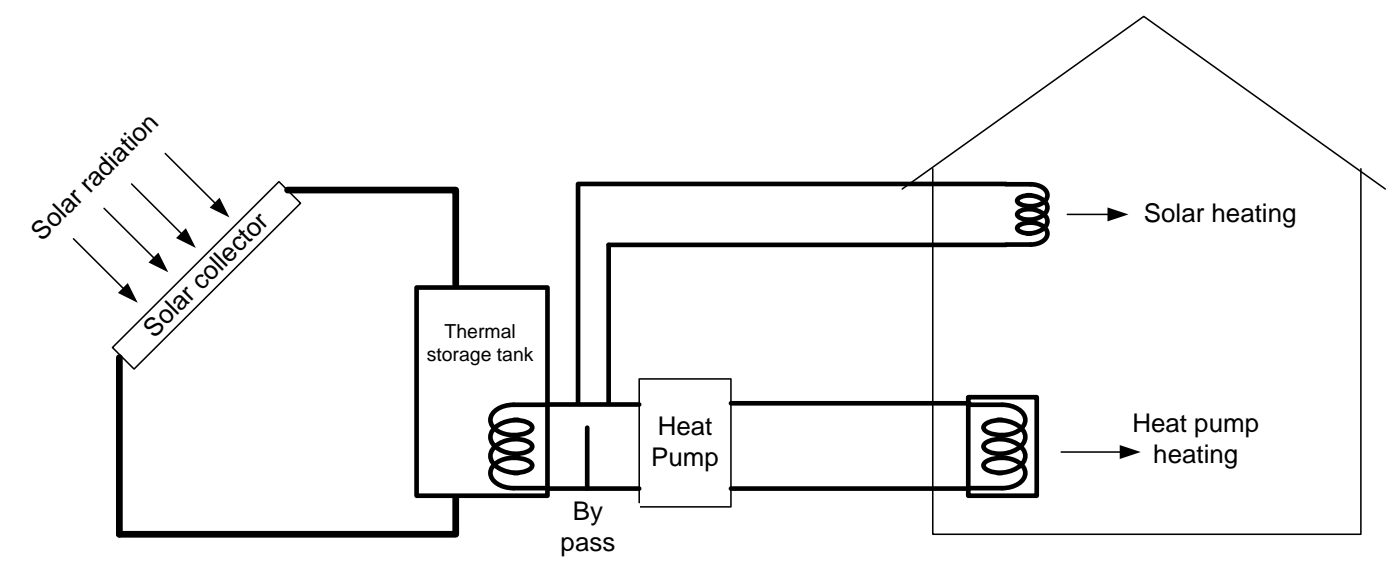

(b) Series SAHP configuration

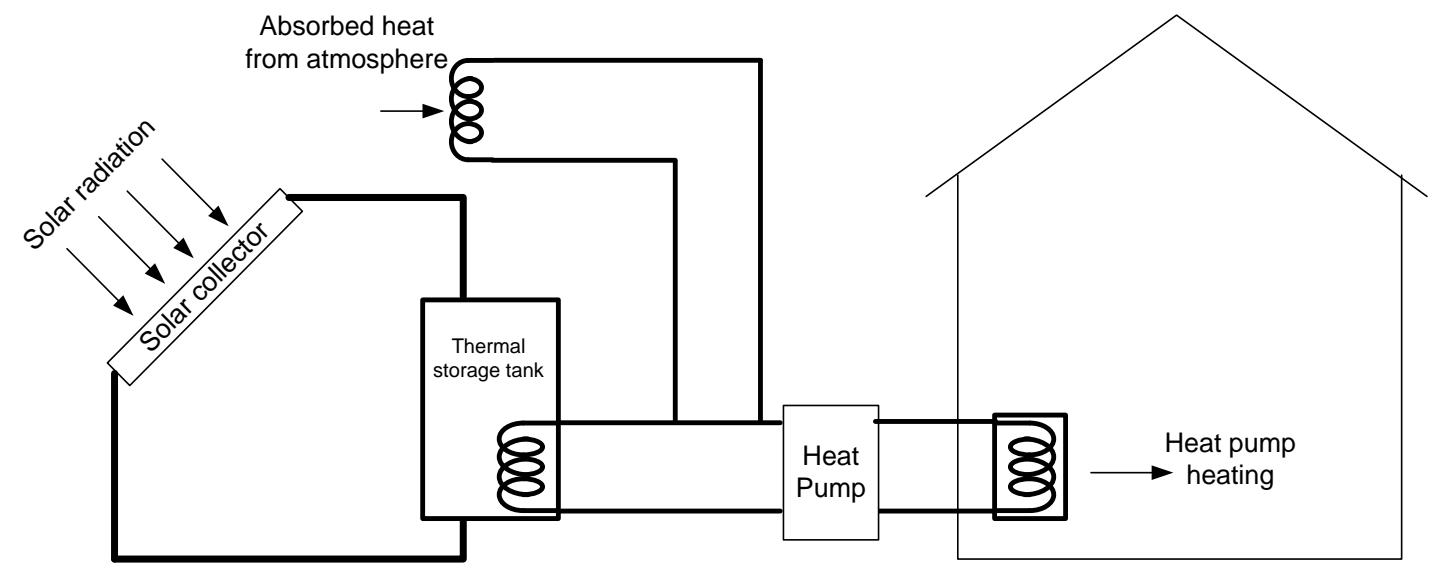

(c) Dual source SAHP configuration

Figure 2-10: Schematic diagram of basic IDX-SAHP system types (Day and Karayiannis, 1994) 
Freeman et al. (1979) compared the three styles of IDX-SAHP systems (series, parallel and dual) for a single-family house using the TRNSYS simulation software. The results of these systems were compared with the results of a typical solar system and a heat pump, which is operated alone. The best performance was for the parallel system with maximum solar collector area of $60 \mathrm{~m}^{2}$. It was found that when the heat pump was connected in series with the solar system, the performance of the connected systems (heat pump + solar collector) was better than each system worked individually; the collector area was more than $12 \mathrm{~m}^{2}$.

Recently, Liang et al. (2011) designed a proposed system for space heating. The system consisted of an ASHP and a solar collection unit. The condenser of the heat pump was connected in series with the solar thermal collector to supply hot water of $45^{\circ} \mathrm{C}$. The system was optimized with different solar collector areas to work in three modes: the first mode worked when the sun was not available or there was low solar intensity, then the space heating was dependent mainly on the heat pump only. In the second mode, the contribution of space heating was done by combination of the solar unit and the heat pump. This mode worked when the solar irradiance was available, but was not enough to produce hot water of $45^{\circ} \mathrm{C}$. The third mode was operated only by the solar collector unit; the solar unit provided adequate thermal energy to increase the water temperature to the desired temperature.

Pogharian et al. (2008) and Candanedo and Athienitis (2008) proposed a design of Alstonvale Net Zero House (ANZH) for net-zero energy applications by reducing the energy demand of the house through a high performance building envelope. The recovered energy from $\mathrm{PV} / \mathrm{T}$ roof system was the main source of a heat pump. For the space heating, the main source was the roof and a glazing section mounted on the same PV/T frame system to enhance heat recovery. The hot air coming from PV/T systems passed over a single air-to-water heat exchanger, acting as the heat source for a heat pump. The heat pump transferred heat to a thermal energy storage (TES). If air temperature was high enough, there was no need to use the heat pump, the heat exchange can happen directly between the air and the storage tank. A typical result of the simulation showed that a configuration with two small parallel heat pumps had a better overall performance than one large heat pump. For the same airflow and temperature, the two heat pumps can provide more than 22 $\mathrm{kW}$ of heat to the thermal storage tank with 5.5 COP. Another advantage of using two heat pumps 
in parallel: it was possible to operate at a lower flow rate even by turning off one of them. Table 2-1 shows a summary of IDX-SAHP used in some studies.

Table 2-1: Categories of IDX-solar assisted heat pump system

\begin{tabular}{|c|c|c|c|}
\hline Heat pump type by source & $\begin{array}{l}\text { SAHP system } \\
\text { category }\end{array}$ & $\begin{array}{l}\text { Thermal storage } \\
\text { material }\end{array}$ & Reference \\
\hline Water source heat pump & Series & $\begin{array}{l}\text { Water/ } \\
\text { Glycol-water } \\
\text { mixture }\end{array}$ & $\begin{array}{l}\text { Bai et al. (2012); Kaygusuz } \\
\text { (2000); Kuang et al. (2003); } \\
\text { Bakirci and Yuksel (2011); } \\
\text { Sterling and Collins (2012) }\end{array}$ \\
\hline $\begin{array}{l}\text { Water evaporator + air } \\
\text { evaporator }\end{array}$ & Dual & Water, PCM & $\begin{array}{l}\text { Liu et al. (2011); Chao et al. } \\
\text { (2010); Wang et al. (2011); } \\
\text { Kaygusuza and Ayhan (1999) }\end{array}$ \\
\hline Air source heat pump & $\begin{array}{l}\text { Series (liquid } \\
\text { solar collector } \\
\text { was connected } \\
\text { in series with } \\
\text { HP condenser) }\end{array}$ & Water & Liang et al. (2011) \\
\hline Air source heat pump & Parallel & Water & Li and Yang (2009) \\
\hline Air source heat pump & Series & ------ & $\begin{array}{l}\text { Karagiorgas et al. (2010); } \\
\text { Loveday (1992) }\end{array}$ \\
\hline
\end{tabular}

\subsection{Solar assisted heat pump for cold climate}

The performance and modeling of combined solar thermal collector and heat pump systems for space heating and water heating purposes have been studied by many researchers. The integrated system of photovoltaic thermal collector and heat pump is controlled according to the design and operation conditions. For cold weather, a geothermal heat pump or an air source heat pump could be used (Stevens et al., 2013; Karlsson et al., 2003; Ecologix Heating Technologies Inc., 2014). The source of the geothermal or ground source heat pump (GSHP) is a well, earth or seawater. It was found that the GSHP covered $90 \%$ of the heating load over a year; an electrical heater was used to cover the rest of the load (Karlsson et al., 2003; Karkkainen and Oy, 2014). A new study performed by Safa et al. (2015) conducted an experimental comparative study between air source heat pump and ground source heat pump. They found that an ASHP could work efficiently in Toronto cold weather (the coldest temperature during the study period was $-22^{\circ} \mathrm{C}$ ) 
without the need to run a supplementary heater. However, it worked at low coefficient of performance of 1.58 .

Ground source heat pumps use long tubes buried under the ground to exchange heat with the ground and need frequent cleaning and flushing of the piping system to ensure proper starting and continued efficient operation (Ecologix Heating Technologies Inc., 2014). Some information should be available about the site, where the GSHP is installed, related to the ground structure (soil, rock, etc.) and the accessibility of underground water (Ozgener and Hepbasli, 2007). However, air source heat pumps use only fan and coil set up as an outdoor unit. Prior to the appearance of variable rate compressor innovation, the performance of the ASHP is decreased rapidly for source temperature less than $5^{\circ} \mathrm{C}$, whereas the constant temperature of the ground permitted ground source heat pump to work efficiently in any weather conditions. Now, the most productive air source heat pumps prove that they start to lose significant heating efficiency at $-15^{\circ} \mathrm{C}$, a change that has made them reasonable in a large portion of North America (Konrad, 2014).

Geothermal heat pumps have good COP and work effectively during cold weather. This is because they collect heat from the ground, where the temperature is nearly constant throughout the year. Therefore, this type of heat pump is commonly operated alone as it can generally give all the heating needs of the building/house where it is installed. However, air source heat pumps are often used with additional heating system, which works as backup during high heating demand. The need to integrate a solar system with ground source heat pump is to regenerate the source (i.e., improve the ground temperature), and importantly is to enhance the solar collector efficiency or merely to prevent solar collector stagnation (stagnation refers to liquid base solar collector). Subsequently, regenerative operation typically happens in summer, when maximum solar radiation is available and least heating demand is required (Ruschenburg et al., 2013; Rad et al., 2013; Wang et al., 2012).

Few studies investigate the possibilities of combining a solar system with air source heat pump. One of the benefits of ASHP is that their cost is much lower than GSHP (Safa et al., 2014). Moreover, some ASHPs types can deliver heating and cooling at the same time, in effect transferring heat from the warmer area in the building (such as a south-facing room) to a colder 
zone in the building. The accumulation of ice and snow on outdoor unit requires the heat pump to deploy a defrost cycle; some installers put the ASHP in a covered "penthouse" near the building exhaust openings to utilize any waste heat (Stevens et al., 2013) (see Figure 2-11). A solar assisted heat pump system may utilize the passive heating from the building envelop. Loveday (1992) performed a study to assess the performance of solar assisted ASHP provided by steel shield an air preheater for heating purposes, primarily for space heating by a thermal storage and partly for domestic hot water production. The heating system consisted of a tile roof with a cavity behind as air channel (the roof is the solar thermal collector) and a heat pump with the split evaporator, which was suited in the attic space. The preheated air from the roof was drawn across the evaporator and ejected to outside. Bags filled with water were recessed into part of the ground to act as thermal storage as shown in Figure 2-12. Table 2-2 shows a summary of various types of solar assisted heat pump from different studies in different locations around the world. Some of these studies were based on only theoretical analysis while others mixed experiments and numerical simulations.

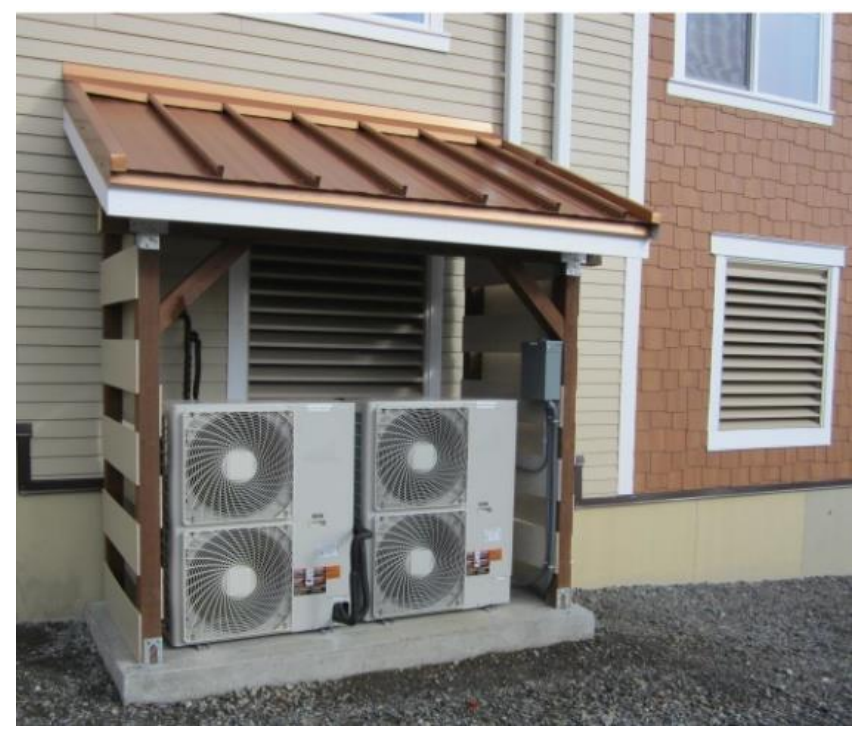

Figure 2-11: These heat pump units are located near the building exhaust vents to utilize any waste heat (Stevens et al., 2013) 


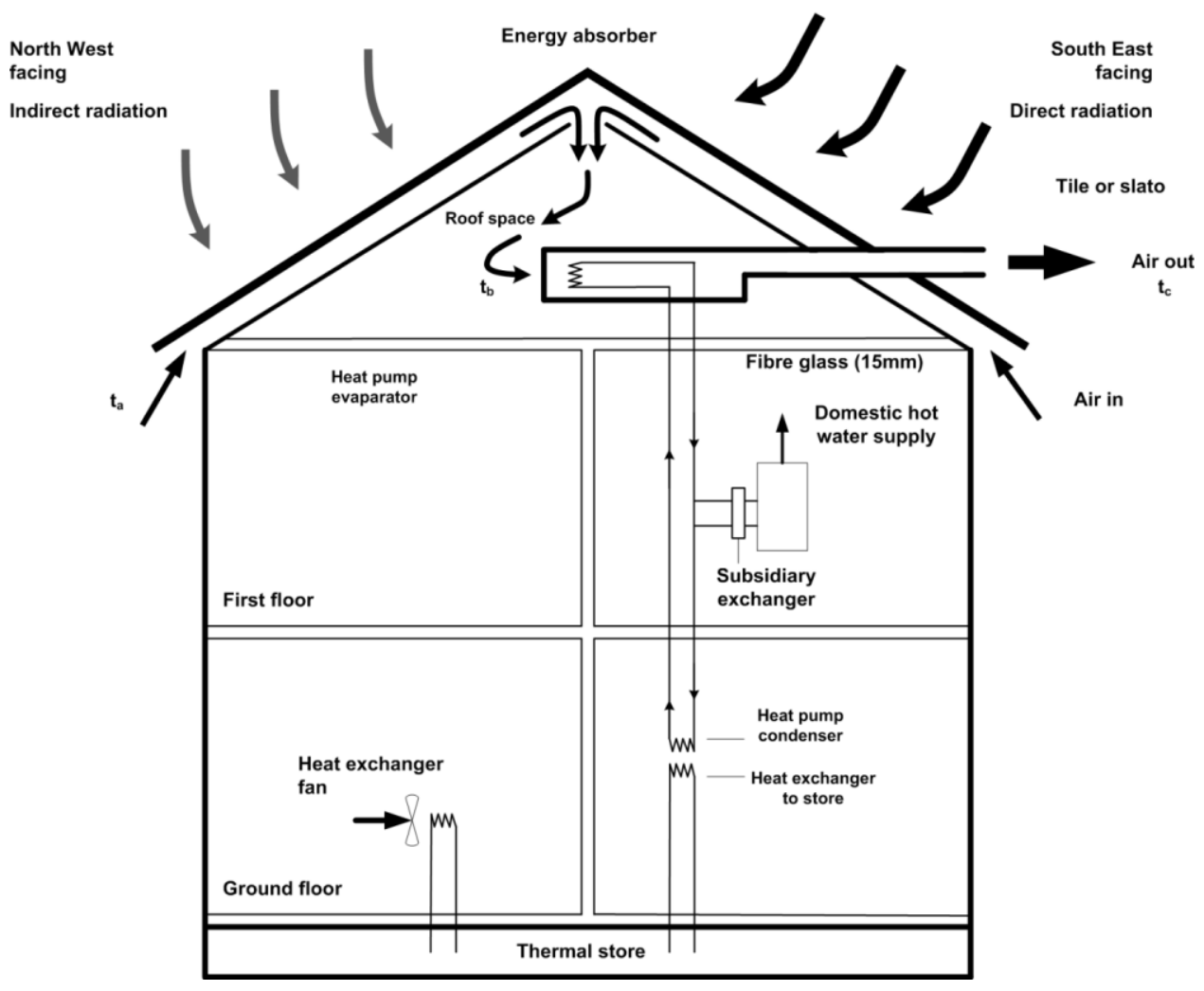

Figure 2-12: Air based solar assisted heat pump using roof as low efficiency solar collector (Loveday, 1992) 


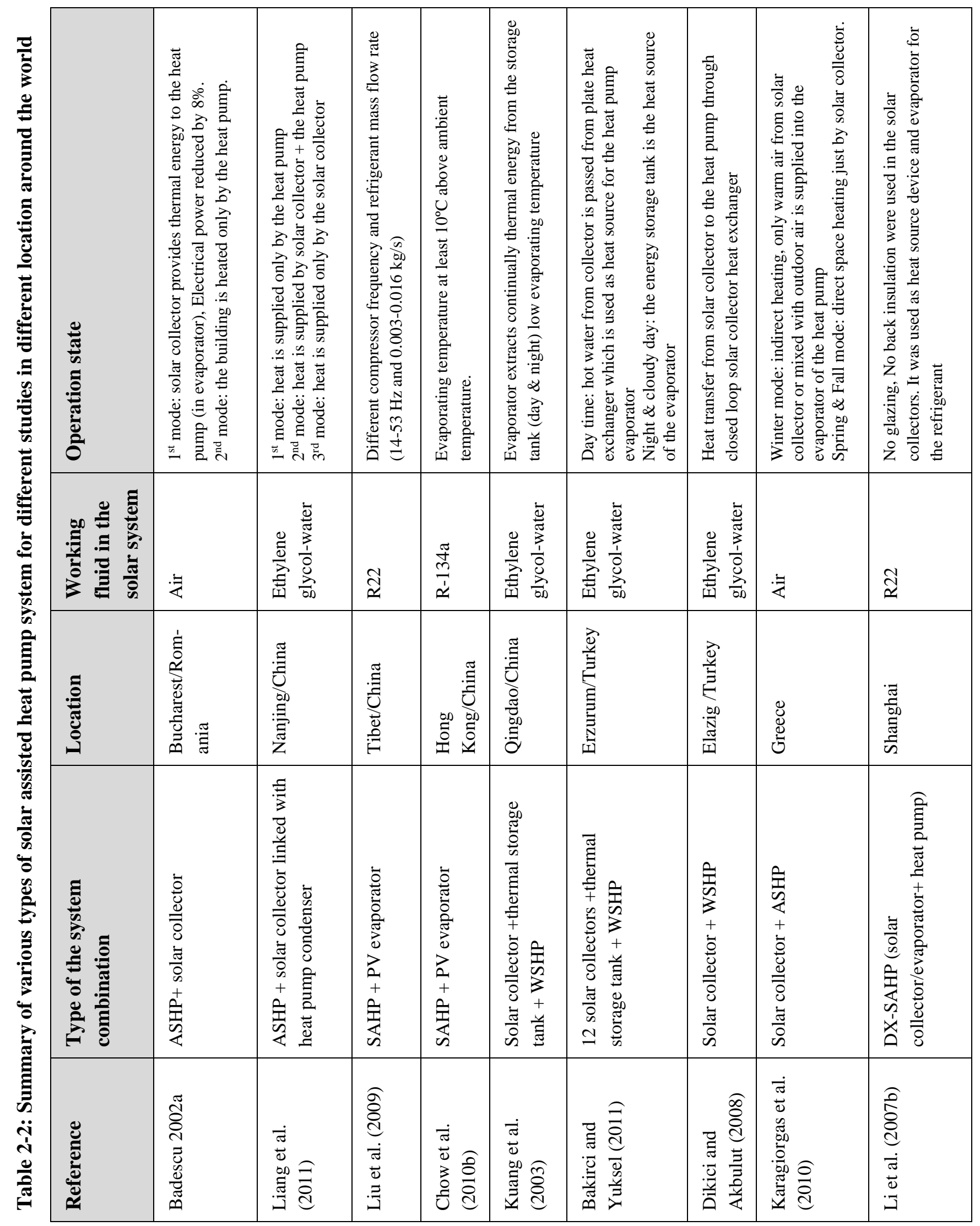




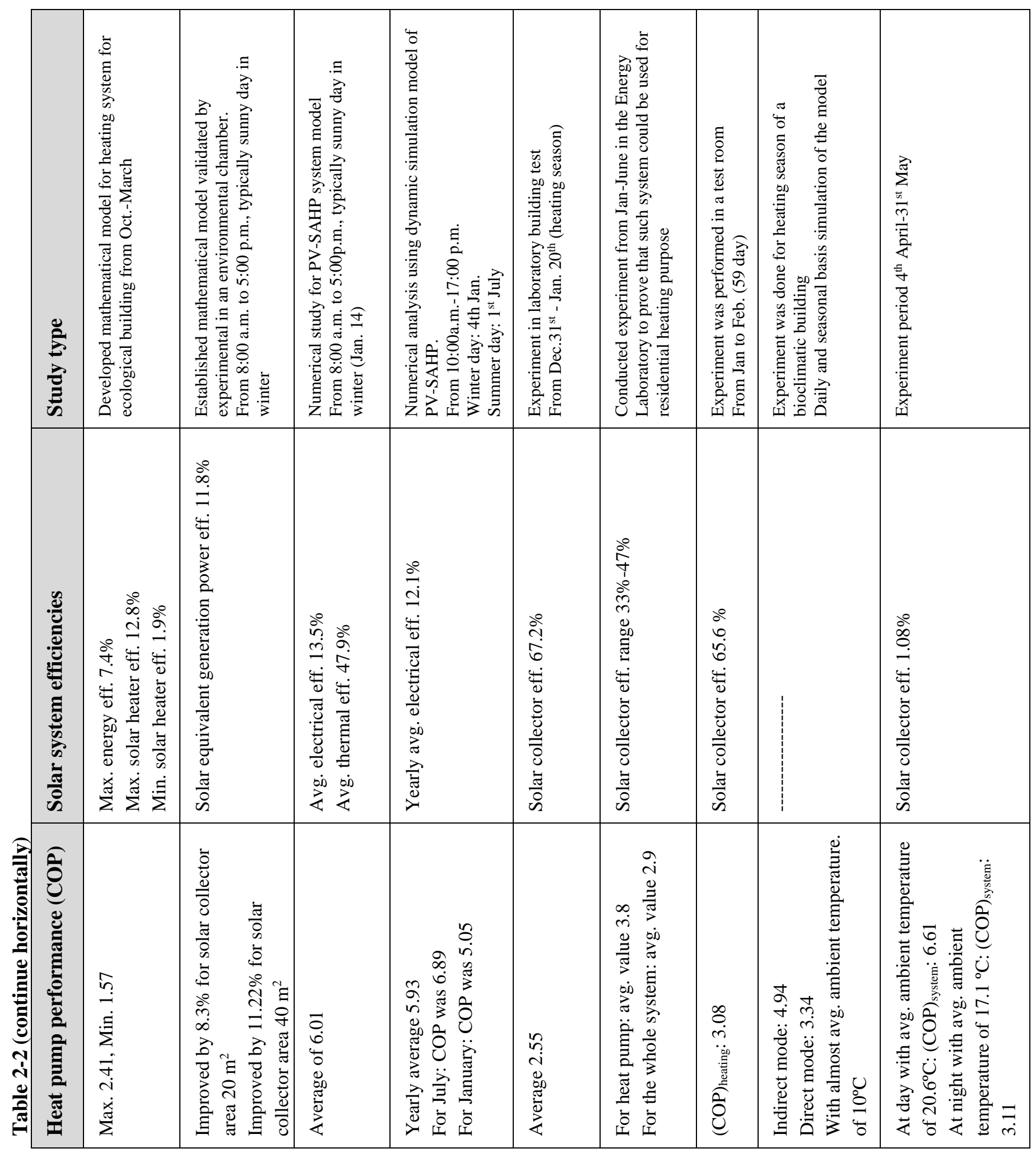


Badescu (2002a) analyzed the model of integrated solar air heater and heat pump for heating purpose. This system worked in two modes to deliver heating to the building. The first mode used the solar air heater working together with the heat pump, the thermal energy collected by the solar collector was used to drive the heat pump. In the second mode, the heating system used only the heat pump. The switching between these two modes was controlled by a selected critical amount of solar irradiance $(\mathrm{Gr})$. When the solar irradiance was greater than the critical value and there was sufficient heat flux to cover the thermal load of the heat pump vaporizer, then the first mode was used. Otherwise, the second was the best choice. The research did include an air thermal storage device. They found that the performance of the heat pump worked together with the solar thermal collector was better than the performance of the heat pump working alone.

Since most of the energy collected by the solar thermal collectors is available during periods with lower thermal load. Therefore, Badescu examined the benefit of using air thermal storage with the combined solar collector and heat pump (Badescu, 2002b; Badescu, 2003) for heating purposes. The energy collected by the solar collector was stored in Thermal Energy Storage (TES) when space heating was not required, smaller TES provided higher amount of heat flux to the heat pump while the bigger TES lasted for a longer time. When space heating was required, there were three possible operating modes. The first mode applied when the solar irradiance exceeded the critical value, part of solar collectors was employed to drive heat pump and the thermal energy collected by the other part was stored in TES. The second and third modes were used when the global solar irradiance was less than the critical value. In this case, if the highest temperature of TES was higher than the ambient temperature, the thermal energy in TES was extracted and transported to the heat pump, and if TES was not charged then the building was heated by the heat pump only. The heat pump depended only on the ambient temperature if it worked alone. Increasing the evaporator temperature decreased the temperature differences between the condenser temperature and the evaporator temperature, and consequently, the heat pump had higher COP. It is found that the saving in electrical energy was $50 \%$ if the thermal energy storage was charged comparing to $20-30 \%$ saving in electricity when the TES was not loaded. 


\subsection{Areas of application}

The photovoltaic/thermal system has potential applications in different sectors such as industrial, commercial, residential, and agricultural. Building integrated PV/T system provides sustainable solution in design structure as part of the building envelop. It could be used for heating, cooling, ventilation, and even hot water production. Several design configurations have been investigated in various building applications regarding the overall energy consumption, heating and cooling load, and energy performance.

PV/T system has potential market for single family and multifamily dwellings/buildings since it provides direct space heating. Chow (2010) stated "PV/T products suit a wide range of applications and market sectors such as property developers, housing authorities, energy companies, owners of recreation and sports centers, public swimming pools, camping sites, and hospitals and hotels. Differences are expected across the climate, terrestrial and cultural boundaries".

Bakirci and Yuksel (2011) conducted an experiment to examine the performance of a SAHP system in a cold area in Turkey for heating purposes. The study showed that thermal energy storage was an important part of solar assisted heat pump system. Chow et al. (2012) investigated potential application for SAHP system for indoor swimming pool. They presented a new design of SAHP for space heating and water-heating purposes. They conducted a study case for a selected community-swimming center in Hong Kong on winter time operation. Their result showed that the proposed system could satisfy the heating demand. The temperature of the flowing water can be heated up to $32{ }^{\circ} \mathrm{C}$ and the space temperature of swimming pool can be kept at $29{ }^{\circ} \mathrm{C}$ during the operating hours.

Chow et al. (2003) investigate the potential applications of photovoltaic-thermal system in large-scale buildings. The study was based on 30-story hotel building to measure the possible benefits of BIPV/T in a practical application. The thermal model was developed with three configuration designs. PV/C design in which air gap opens at all sides of PV panels, PV/T design which has air gap at top and bottom ends only, and BIPV design in which the PV panels are installed directly on the external wall. The PV/C option was the best for summer months; the PV/T one was more productive for the winter. 
Vokas et al. (2006) conducted analysis of a photovoltaic-thermal system for space heating and cooling. This analysis was based on analytical approach of F-chart method presented by Klein (1997) for heating season and cooling season. The calculations showed that the thermal efficiency of the PV/T system was 9\% less compared to the conventional solar collector, and the photovoltaicthermal system could produce thermal energy that covered part of the heating load.

Photovoltaic-thermal collectors could be used for radiative cooling in a buildings during night. Radiative cooling concept is heat lost during night by the emission of long wave radiation to sky. Eicker and Dalibard (2011) developed a new system of PV/T for cooling purpose in addition to electricity generation. The selected design of the PV/T module was an uncovered design with closed water system glued to PV panels to maximize heat transfer through long wave radiation emission from the PV/T collector. The system was built in a house and verified under real weather conditions of Madrid; the average cooling energy was $41 \mathrm{~W} / \mathrm{m}^{2}$.

In agricultural sector, PV/T system can be used for heating, cooling and crop drying. Nayak and Tiwari (Nayak and Tiwari, 2008, 2009, 2010) carried out energy analysis to estimate the performance of photovoltaic/thermal collectors for greenhouse in Delhi, India. Numerical computation was performed, and it was observed that theoretical values of solar cells temperatures and greenhouse air temperatures were almost comparable to the experimental data.

Solar assisted heat pump to dry crops was investigated by researchers (Pendyala et al., 1986, 1990; Hawlader et al., 2003, 2006, 2008; Kiang and Jon, 2006), the integrated system could be used for DHW and drying (Hawlader et al., 2003, 2006). In such a system, there are two flow paths: air and refrigerant. The drying air enters the drying chamber and removes moisture from the product. Then, it passes the evaporator, which acts as dehumidifier, to remove the vapor. The collected heat is driven to the condenser. Air is reheated again by passing through the solar collector, then, enters the condenser.

Al-Amri (1997) studied the possibility of utilizing solar energy system in heating the interior air of a gable even-span greenhouse. An arithmetic program was employed to estimate the solar radiation flux. The results of the experimental work showed that the specific approach of heating the greenhouse for tomato production enhanced the rate of growth and increased the fresh tomato yield by $46.67 \%$. Barnwal and Tiwari (2008) performed an experimental study to evaluate 
the drying process of grapes in a hybrid photovoltaic-thermal integrated greenhouse dryer under forced circulated air mode. The electricity provided by PV/T system was employed to operate the fan for forced mode operation, and the produced thermal energy helped in drying of crops.

\subsection{Summary of literature review}

A comprehensive review of solar systems (solar thermal collectors and photovoltaicthermal (PV/T) collectors) and solar assisted heat pumps with their applications are presented in this chapter. Most of the solar assisted heat pump systems which were presented in studies and researches, consist of solar thermal collector, which produces only thermal energy, linked with the evaporator of a heat pump, i.e., thermal energy is extracted from the solar thermal system for heating purposes only. The only integrated PV/T system with a heat pump, which provides both thermal energy and electrical power, is the PV-evaporator type. In such a system, the solar collector is considered the evaporator of the heat pump. During the day, there is a possibility of liquid refrigerant remaining at the outlet of the PV-evaporator because solar radiation changes; consequently, the system works inefficiently and will require control of the mass flow rate of the refrigerant. In addition, the system works only when evaporator temperature is above a certain value. It may be beneficial to overcome this issue by separating the PV/T unit from the heat pump evaporator.

Most of the research covered in this chapter illustrates that the dominant source of solar assisted heat pump is a liquid system with water thermal storage (which is normally located between the heat pump and the solar collector for an ID-SAHP). SAHPs of this type are used only for heating purposes (space heating or hot water production). The reviewed work shows that there is a lack of investigations of connecting an air-based solar system (especially PV/T system) with an air source heat pump, including air-based thermal energy storage. There is flexibility for such an integrated system to work at night and day, providing heating and cooling. In this case, the operation conditions will not be affected by solar irradiance intensity.

It is obvious from the review that solar systems have different applications depending on purposes and locations. The majority of the applications for building integrated solar systems consist of only photovoltaic-thermal collectors without heat pump. For cold countries, solar 
systems are used for space heating; while in warm countries, solar systems are generally employed for heating water in residential houses with liquid as the working fluid. 


\section{Chapter 3: Modeling of Opaque Photovoltaic-Thermal (PV/T) Collector}

This chapter presents:

i. Model development of opaque photovoltaic-thermal (PV/T) collector to conduct comprehensive analysis in order to predict the effect of PV/T system arrangement of $\mathrm{N}_{\mathrm{S}} \times$ $\mathrm{N}_{\mathrm{R}}$ (The configuration arrangement consists of a number of rows of PV/T systems $\mathrm{N}_{R}$ connected in parallel and each row consists of PV/T systems connected in series $\mathrm{N}_{\mathrm{S}}$ ), air mass flow rate and duct depth on thermal energy production, electrical energy production and overall PV/T system efficiency.

ii. A discussion of the necessity of a simulation tool to model Building Integrated Photovoltaic/Thermal (BIPV/T) collector. This chapter also presents existing TRNSYS BIPV/T component types. The selected type was modified. Some changes were based on the developed PV/T model.

iii. The modified BIPV/T type was used to model opaque BIPV/T system with a single zone house using TRNSYS. The TRNSYS model was run to investigate the impact of different parameters on BIPV/T performance. (The same house model will be used later in Chapter 4 for Transparent BIPV/T system performance analysis).

\subsection{PV/T collector analysis methods}

The modeling approach of a solar PV/T collector is either steady state approach (Tonui and Tripanaganostopoulos, 2007a, 2007b; Garg and Adhikari, 1997; Sopian et al., 1996; Zhai et al., 2005) or transient approach (Prakash, 1994; Garg and Adhikari, 1998; Candanedo et al., 2010; Ito et al., 2006). The transient solution requires the results from a previous time step, is more stable, and gives results with less fluctuation. The fluctuation occurs due to the changes in weather such as solar intensity and wind speed. Candanedo et al. (2010) compared steady and unsteady models of PV/T systems. In the study, the transient model included the thermal capacitance effect of the PV panel. The outcomes from the steady and transient models were compared with experimental results of 1 minute intervals. The transient model showed a more accurate outlet temperature due to considering the thermal capacitance effect. However, both models, in general, showed an acceptable agreement with experimental results. The study showed that the average accuracy of the results was not improved considerably by transient model. Therefore, Candanedo et al. (2010) 
stated that the transient model may not be required for system design and general analysis, but it is required for optimal control of the air flow rate. Klein et al. (1974) examined the impact of including the heat capacity in a flat plate solar collector performance to reduce the effect of the continuous variation of weather parameters. They investigated three models of a solar collector: zero capacitance model, single value of thermal capacity (one node) and multi node model. The study found that the model of zero capacity is sufficient to predict the performance of a flat plate solar collector for hourly meteorological data. Since the analysis in this thesis is based on hourly weather data, so the capacity effects of the PV panel is neglected.

\subsection{Energy model of a hybrid Photovoltaic-Thermal (PV/T) air collector}

In this section, a comprehensive analysis is conducted to predict the effect of PV/T system arrangement, air mass flow rate, and duct depth on thermal energy production, electrical energy production, and overall PV/T system efficiency. Several assumptions were made to simplify the analysis:

(1) Capacitance effects of system components are negligible except for flowing air.

(2) The upper- and lower-channel heat transfer coefficients are identical.

(3) Side and backside losses are negligible.

(4) Properties of air and solid material remain constant.

(5) The temperature variations are considered only in the flow direction, i.e., one dimension.

Figure 3-1 shows a cross section of the PV/T system. In order to make the model simple, the thermal node of the cover glass was ignored. In addition, the heat transfer between the backside surface of the PV/T collector and the interface zone was ignored. In this case, the temperature of the back surface of the insulation, $\mathrm{T}_{3}$, was assumed to be the same temperature of the air/collector back interface zone; for instance, the value is $20^{\circ} \mathrm{C}$ for heating season.

Based on these assumptions and considering an elemental area of bdx, where $b$ is the width of the PV/T system into the page, the energy balance equations for the PV cells, Tedlar back surface of the PV panel, air flowing in the duct of PV/T, and lower surface of air channel can then be written as follows: 


$$
\begin{gathered}
\left(\tau_{\mathrm{g}} \alpha_{\mathrm{PV}} \mathrm{P}_{\mathrm{F}} \mathrm{I}_{\mathrm{T}}+\tau_{\mathrm{g}}\left(1-\mathrm{P}_{\mathrm{F}}\right) \alpha_{\mathrm{T}} \mathrm{I}_{\mathrm{T}}-\eta_{\text {panel }} \mathrm{I}_{\mathrm{T}}\right) \mathrm{bdx}= \\
\mathrm{h}_{\mathrm{rs}}\left(\mathrm{T}_{\mathrm{PV}}-\mathrm{T}_{\mathrm{S}}\right) \mathrm{bdx}+\mathrm{U}_{\text {top }}\left(\mathrm{T}_{\mathrm{PV}}-\mathrm{T}_{\mathrm{amb}}\right) \mathrm{bdx}+\mathrm{U}_{\mathrm{back}}\left(\mathrm{T}_{\mathrm{PV}}-\mathrm{T}_{1}\right) \mathrm{bdx} \\
\mathrm{U}_{\mathrm{back}}\left(\mathrm{T}_{\mathrm{PV}}-\mathrm{T}_{1}\right) \mathrm{bdx}=\mathrm{h}_{\mathrm{air}}\left(\mathrm{T}_{1}-\mathrm{T}_{\mathrm{air}}\right) \mathrm{bdx}+\mathrm{h}_{r_{1-2}}\left(\mathrm{~T}_{1}-\mathrm{T}_{2}\right) \mathrm{bdx} \\
\dot{\mathrm{m} C} \frac{\mathrm{dT}_{\mathrm{air}}}{\mathrm{dx}} \mathrm{dx}=\mathrm{h}_{\mathrm{air}}\left(\mathrm{T}_{1}-\mathrm{T}_{\mathrm{air}}\right) \mathrm{bdx}+\mathrm{h}_{\mathrm{air}}\left(\mathrm{T}_{2}-\mathrm{T}_{\mathrm{air}}\right) \mathrm{bdx} \\
\mathrm{h}_{\mathrm{air}}\left(\mathrm{T}_{\mathrm{air}}-\mathrm{T}_{2}\right) \mathrm{bdx}+\mathrm{h}_{r_{1-2}}\left(\mathrm{~T}_{1}-\mathrm{T}_{2}\right) \mathrm{bdx}=\mathrm{U}_{\text {ins }}\left(\mathrm{T}_{2}-\mathrm{T}_{3}\right)
\end{gathered}
$$

The energy balance Equations (3-1) to (3-4) have been solved to determine the outlet temperature of the flowing air $\left(\mathrm{T}_{\text {out }}\right)$ in the duct of the PV/T system. The differential Equation (3-5) is obtained.

$$
\frac{\mathrm{dT}_{\mathrm{air}}}{\mathrm{dx}}=\left(\frac{\mathrm{b}}{\dot{\mathrm{m} C}}\right) \mathrm{B}_{1}+\left(\frac{\mathrm{b}}{\dot{\mathrm{m} C}}\right) \mathrm{B}_{2} \mathrm{~T}_{\mathrm{air}}
$$

Where:

$$
\begin{aligned}
& \mathrm{B}_{1}=-\frac{\mathrm{h}_{r_{1-2}} \mathrm{~h}_{\mathrm{air}} \mathrm{N}}{\mathrm{MF}}-\frac{\mathrm{h}_{\text {air }} \mathrm{K}_{1}}{\mathrm{M}}+\frac{\mathrm{h}_{\text {air }} \mathrm{N}}{\mathrm{F}} \\
& \mathrm{B}_{2}=\frac{\mathrm{W} \mathrm{h}_{\text {air }}}{\mathrm{F}}-\frac{\mathrm{h}_{\text {air }}{ }^{2}}{\mathrm{M}}-\frac{\mathrm{h}_{\text {air }} \mathrm{h}_{r_{1-2}} \mathrm{~W}}{\mathrm{MF}}-2 \mathrm{~h}_{\text {air }}
\end{aligned}
$$

See Appendix A for definitions of F, K, M, N, W, $\mathrm{U}_{\text {back }}$, $\mathrm{U}_{\text {top }}$ and $\mathrm{U}_{\text {ins }}$.

Equation (3-5) could be solved by using the following boundary condition:

$$
\mathrm{T}_{\mathrm{air}}=\mathrm{T}_{\mathrm{amb}} \text { at } \mathrm{x}=0
$$

Finally, the solution is

$$
\mathrm{T}_{\text {air }}(\mathrm{x})=-\frac{\mathrm{B}_{1}}{\mathrm{~B}_{2}}+\left(\mathrm{T}_{\mathrm{amb}}+\frac{\mathrm{B}_{1}}{\mathrm{~B}_{2}}\right) \mathrm{e}^{\frac{\mathrm{bB_{2 } \mathrm { x }}}{\mathrm{m} \mathrm{C}}}
$$

At $\mathrm{x}=\mathrm{L}$, the final outlet temperature will be:

$$
\mathrm{T}_{\text {out }}=\mathrm{T}(\mathrm{L})=-\frac{\mathrm{B}_{1}}{\mathrm{~B}_{2}}+\left(\mathrm{T}_{\mathrm{amb}}+\frac{\mathrm{B}_{1}}{\mathrm{~B}_{2}}\right) \mathrm{e}^{\frac{\mathrm{bB} \mathrm{B}_{2} L}{\mathrm{mC}}}
$$

The average air temperature can be found by integrating Equation (3-9) for the entire PV/T system length, L, and divided by L (John and William, 2006):

$$
\mathrm{T}_{\text {average }}=\frac{1}{\mathrm{~L}} \int_{0}^{\mathrm{L}} \mathrm{T}(\mathrm{x}) \mathrm{dx}
$$


Obtaining:

$$
\mathrm{T}_{\text {average }}=\frac{\left(\mathrm{T}_{\mathrm{amb}}+\frac{\mathrm{B}_{1}}{\mathrm{~B}_{2}}\right) \dot{\mathrm{mC}}}{\mathrm{LbB}_{2}}\left[\mathrm{e}^{\frac{\mathrm{LbB}_{2}}{\dot{\mathrm{m} C}}}-1\right]-\frac{\mathrm{B}_{1}}{\mathrm{~B}_{2}}
$$

After finding the average air temperature inside the duct $\left(\mathrm{T}_{\text {average }}\right)$, the mean $\mathrm{PV} / \mathrm{T}$ surface temperatures $\left(\mathrm{T}_{1}, \mathrm{~T}_{\mathrm{PV}}\right.$ and $\left.\mathrm{T}_{2}\right)$ are obtained. A MATLAB code was developed to solve the model.

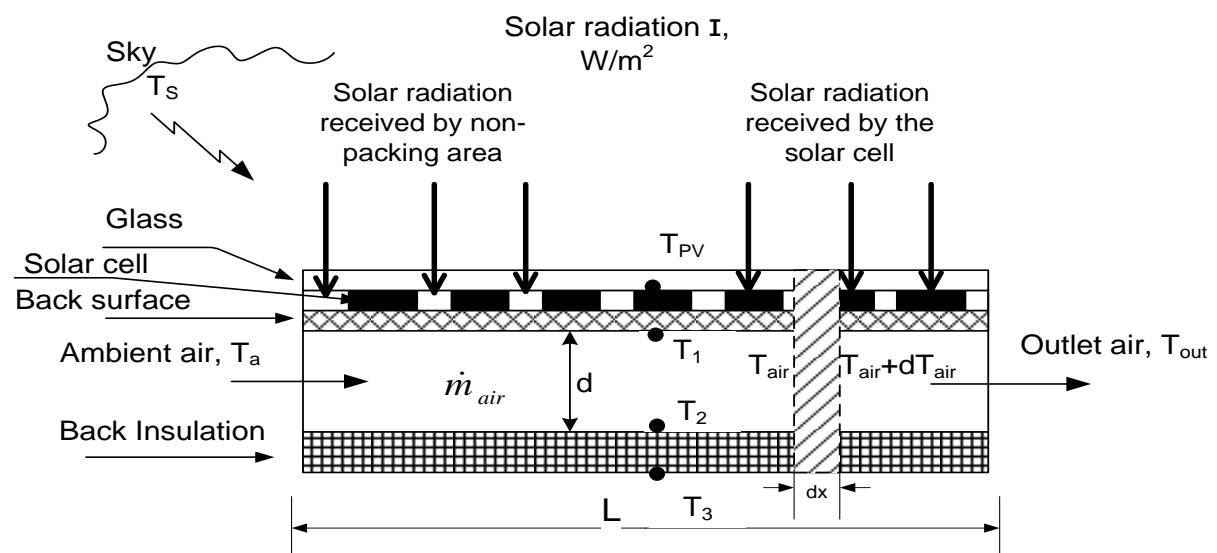

Figure 3-1: Cross section for energy balance of the PV/T collector with air flow pattern over elemental area bdx

\subsubsection{Estimation of Heat Transfer Coefficients}

The radiative heat transfer coefficients, $h_{r s}$ and $h_{r_{1-2}}$, between the PV panel and the atmosphere and between the upper surface and lower surface of the air channel respectively, can be obtained as (John and William, 2006):

$$
\begin{aligned}
& \mathrm{h}_{\mathrm{rs}}=\sigma \epsilon\left(\mathrm{T}_{\mathrm{PV}}+\mathrm{T}_{\mathrm{s}}\right)\left(\mathrm{T}_{\mathrm{PV}}^{2}+\mathrm{T}_{\mathrm{s}}^{2}\right) \\
& \mathrm{h}_{r_{1-2}}=\frac{\sigma\left(\mathrm{T}_{1}^{2}+\mathrm{T}_{2}^{2}\right)\left(\mathrm{T}_{1}+\mathrm{T}_{2}\right)}{\frac{1}{\epsilon_{1}}+\frac{1}{\epsilon_{2}}-1}
\end{aligned}
$$

where $\mathrm{T}_{\mathrm{PV}}, \mathrm{T}_{\mathrm{S}}, \mathrm{T}_{1}$, and $\mathrm{T}_{2}$ are in $\mathrm{K}$.

The forced convective heat transfer coefficient for the air inside the duct can be obtained from the following equations (John and William, 2006):

For laminar flow: 


$$
\operatorname{Re}<2300: \quad \mathrm{Nu}=4.9+\frac{0.0606\left(\operatorname{Re} \operatorname{Pr} \mathrm{D}_{\mathrm{h}} / \mathrm{L}\right)^{1.2}}{1+0.0909\left(\operatorname{Re} \operatorname{Pr} \mathrm{D}_{\mathrm{h}} / \mathrm{L}\right)^{0.7} \operatorname{Pr}^{0.17}}
$$

John and William (2006) derived an expression of Reynolds number for fully developed turbulent flow inside solar air heater with one side insulated and the other side heated:

$$
\mathrm{Nu}=0.0158 R e^{0.8}
$$

The entrance effect was considered in calculating convection heat transfer for air flow inside the channel. The convective heat transfer coefficient is higher at the entrance region before the fully developed flow is reached. In Equation (3-17), the part in brackets was considered by Kays and Crawford (1993) to include the effect of the entrance region and was multiplied by the Nusselt number for fully developed flow presented by John and William (2006). For abruptcontraction entrance, $\mathrm{C}_{\mathrm{x}}=6$ was used.

$$
\begin{aligned}
& \mathrm{Nu}=0.0158 R e^{0.8}\left[1+\frac{\mathrm{C}_{\mathrm{x}}}{\mathrm{L} / \mathrm{D}_{\mathrm{h}}}\right] \\
& \operatorname{Re}=\frac{\rho_{\text {air }} V D_{h}}{\mu}=\frac{\frac{\dot{m}}{b d} D_{h}}{\mu} \\
& \mathrm{D}_{\mathrm{h}}=\frac{4(\mathrm{~b} \mathrm{~d})}{2(\mathrm{~b}+\mathrm{d})} \\
& h_{\text {air }}=\frac{N u k_{\text {air }}}{D_{h}}
\end{aligned}
$$

Sky temperature has been calculated using the following formula (Eicker, 2003):

$$
\mathrm{T}_{\mathrm{s}}=0.037536 \mathrm{~T}_{\mathrm{amb}}^{1.5}+0.32 \mathrm{~T}_{\mathrm{amb}}
$$

Ambient air temperature unit in Equation (3-21) is Kelvin.

\subsubsection{Electrical model}

Skoplaki and Palyvos (2009) presented a list of various PV panel efficiency expressions as a function of the PV panel temperature. The most common correlation was presented by Evan (1981):

$$
\eta_{\text {panel }}=\eta_{\text {ref }}\left[1-\mathrm{Eff}_{T}\left(\mathrm{~T}_{\mathrm{PV}}-\mathrm{T}_{\mathrm{ref}}\right)\right]
$$


Equation (3-22) is known as the traditional linear relation of the PV panel electrical efficiency. The parameter $\mathrm{Eff}_{T}$ is the efficiency temperature coefficient; the average value of $0.0045 \mathrm{~K}^{-1}$ for a PV/T system was used (Skoplaki and Palyvos, 2009).

\subsubsection{Methodology}

As it mentioned earlier, the mathematical model was used to conduct a comprehensive analysis to investigate the effect of PV/T system arrangement configuration, air mass flow rate and duct depth on thermal energy production, electrical energy production and overall PV/T system efficiency. Figure 3-2 shows the configuration arrangement $\mathrm{N}_{S} \times \mathrm{N}_{\mathrm{R}}$ of the PV/T array used in the analysis in this chapter.

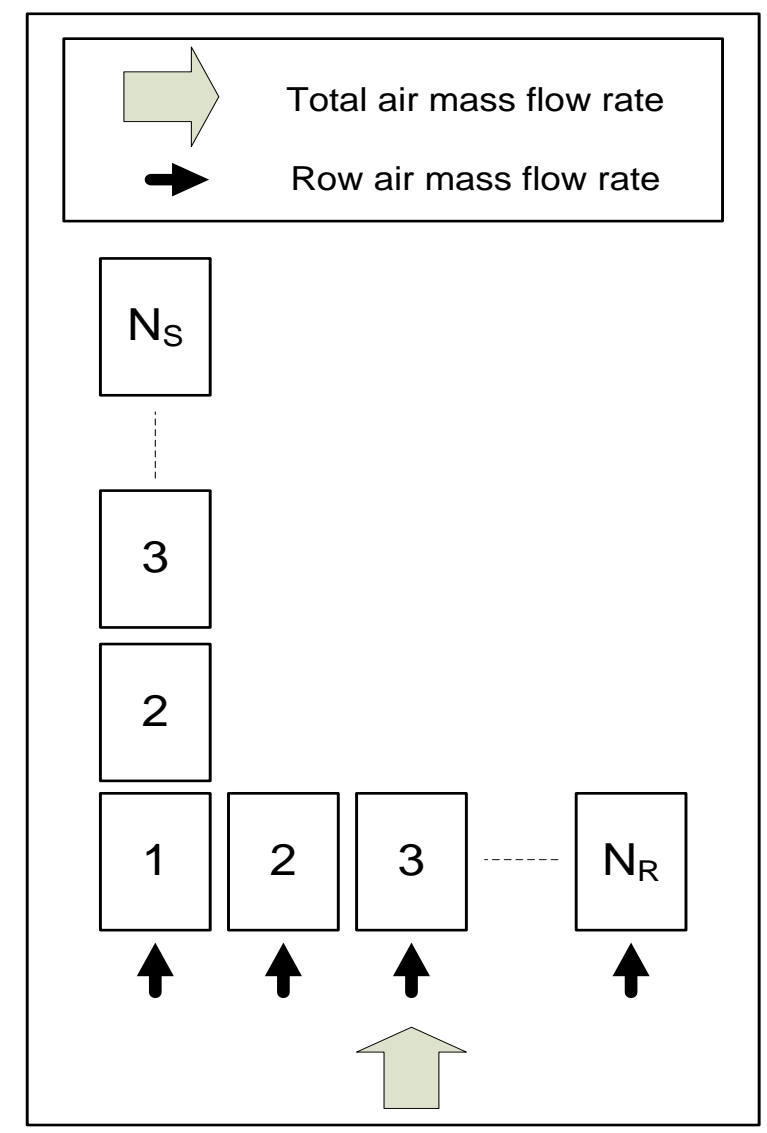

Figure 3-2: Configuration of the PV/T systems

Table 3-1 presents the physical properties of the air and assumed design parameters of PV/T system for this analysis. 
Table 3-1: Physical properties and design parameters used in solving the mathematical model

\begin{tabular}{|c|c|}
\hline $\boldsymbol{\tau}_{\mathbf{g}}$ & 0.95 \\
\hline $\boldsymbol{\alpha}_{\mathbf{P V}}$ & 0.9 \\
\hline $\boldsymbol{\alpha}_{\mathbf{T}}$ & 0.7 \\
\hline $\boldsymbol{\epsilon}$ & 0.6 \\
\hline $\boldsymbol{\epsilon}_{\mathbf{1}}$ & 0.9 \\
\hline $\boldsymbol{\epsilon}_{\mathbf{2}}$ & 0.9 \\
\hline $\mathbf{P}_{\mathbf{F}}$ & 0.95 \\
\hline $\mathbf{b}$ & $0.8 \mathrm{~m}$ \\
\hline $\mathbf{L}$ & $1.55 \mathrm{~m}$ \\
\hline $\mathbf{C}$ & $1007 \mathrm{~J} / \mathrm{kg} \mathrm{K}$ \\
\hline $\mathbf{k}_{\mathbf{g}}$ & $1.06 \mathrm{~W} / \mathrm{m} \mathrm{K}$ \\
\hline $\mathbf{L}_{\mathbf{g}}$ & $3.2 \mathrm{~mm}$ \\
\hline $\mathbf{k}_{\text {back }}$ & $2 \mathrm{~W} / \mathrm{mK}$ \\
\hline $\mathbf{L}_{\text {back }}$ & $5 \mathrm{~mm}$ \\
\hline $\mathbf{k}_{\text {ins }}$ & $0.035 \mathrm{~W} / \mathrm{mK}$ \\
\hline $\mathbf{L}_{\text {ins }}$ & $50 \mathrm{~mm}$ \\
\hline $\boldsymbol{\rho}_{\text {air }}$ & $1.292 \mathrm{~kg} / \mathrm{m}^{3}$ \\
\hline $\boldsymbol{\eta}_{\text {ref }}$ & $13.9 \%$ \\
\hline & \\
\hline
\end{tabular}

Hourly solar radiation on tilted surface, ambient air temperature and wind velocity for Toronto were obtained from Meteonorm weather data. These data were used as input for solving the mathematical model. The tilt angle for the PV/T system was selected as $45^{\circ}$ (Hailu and Fung, 2013). The calculations have been done only for the heating season which was supposed to start on October 1 and end on May 22.

The calculations have been performed panel by panel connected in series. The temperature of the air which enters the first PV/T system is considered to be the ambient air temperature; the outlet air temperature $\left(\mathrm{T}_{\text {out }}\right.$ ) coming out from each $\mathrm{PV} / \mathrm{T}$ system is considered to be the input air temperature for the next PV/T panel. The final outlet air temperature was used to calculate the rate of thermal energy extracted from the PV/T system per row. Different configuration arrangements, different mass flow rates, and different duct depth for the PV/T systems have been studied in order 
to estimate the best arrangment to maximize the recovery of solar thermal energy and electrical energy production. For the arrangement shown in Figure 3-2, the air enters at constant mass flow rate and is equally distributed in rows.

It is known that the electrical efficiency of the PV panels is affected by its temperature. Therefore, when the panel mean temperature $\left(\mathrm{T}_{\mathrm{PV}}\right)$ was calculated, a new value of the efficiency of each PV panel ( $\left.\eta_{\text {panel }}\right)$ was estimated using Equation (3-22). Since the air becomes warmer in moving forward under the PV panels, the first panel has higher efficiency and produces more electricity than the second PV panel. The second PV panel produces more electricity than the third one and so on. After obtaining the efficiency for each panel corresponding to its temperature, the electrical power per panel was obtained from the following equation:

$$
\mathrm{E}=\eta_{\text {panel }} \mathrm{bLI} \mathrm{I}_{\mathrm{T}}
$$

The thermal energy for each row was estimated from the following equation:

$$
\mathrm{Q}=\dot{\mathrm{m}} \mathrm{C}\left(\mathrm{T}_{\mathrm{out}}-\mathrm{T}_{\mathrm{amb}}\right)
$$

After obtaining the thermal power (Q) and the electrical power (E) for the whole arrangement of $\mathrm{PV} / \mathrm{T}$ system, the overall efficiency for PV/T system is then calculated using Equation (3-25):

$$
\eta_{P V / T}=\frac{E+Q}{I_{T} b L}
$$

\subsubsection{Analyzing PV/T system arrangement}

Figures 3-3(a) and 3-3(b) represent the electricity and the thermal energy production for one row $\left(\mathrm{N}_{S}\right)$ and for the whole array with different number of series and row $\left(\mathrm{N}_{S} \times \mathrm{N}_{\mathrm{R}}\right), 1.2 \mathrm{~kg} / \mathrm{s}$ as total mass flow rate, and $\mathrm{d}=38 \mathrm{~mm}$. For individual rows (Figure 3-3(a)), it is shown that for the same $\mathrm{N}_{\mathrm{R}}=5$, the configuration with $\mathrm{N}_{\mathrm{S}}=5$ makes larger amount of row thermal energy than the configuration with $\mathrm{N}_{S}=3$ and $\mathrm{N}_{S}=4$. While for the same $\mathrm{N}_{S}=5$, the configuration with $\mathrm{N}_{R}=3$ makes larger amount of row thermal energy than the configuration with $N_{R}=4$ and $N_{R}=5$. This is because the row mass flow rate is obtained by dividing the total mass flow rate by $\mathrm{N}_{\mathrm{R}}$. Therefore, one row of the $5 \times 3$ array, which produces the highest thermal energy among the other arrays, has the largest row mass flow rate $(0.4 \mathrm{~kg} / \mathrm{s})$ and the highest $\mathrm{T}_{\text {out }}$. Nevertheless, the maximum thermal energy produced from the whole array (Figure $3-3($ b)) is obtained by the $5 \times 5$ configuration because 
there are more rows and accordingly more thermal energy. Also, the total thermal energy generation during the heating season with different values of total mass flow rate was calculated for different $\left(\mathrm{N}_{S} \times \mathrm{N}_{\mathrm{R}}\right)$; it is observed that a total thermal energy of $10827 \mathrm{kWh}$ can be reached with the lowest depth, $d=38 \mathrm{~mm}$, and the highest total mass flow rate of $2 \mathrm{~kg} / \mathrm{s}$ for the $5 \times 5$ arrangement as shown in Figure 3-4. The electricity production depends on the number of panels. In Figure 33(a), it is obvious that arrangement with $\mathrm{N}_{\mathrm{S}}=5$ produces more electricity per row than the arrays with less Ns. In Figure 3-3(b), for the whole arrangement, $5 \times 5$ arrangement produces the highest amount of electricity $3964 \mathrm{kWh} /$ heating season since there are $25 \mathrm{PV}$ panels in this array.

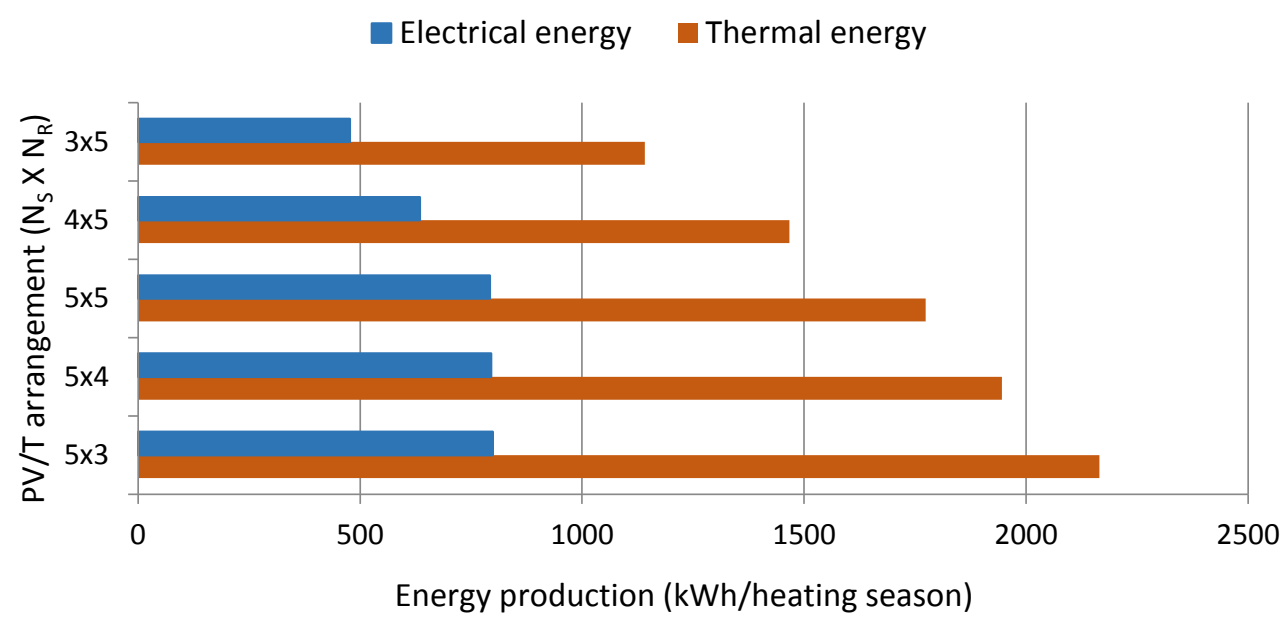

(a)

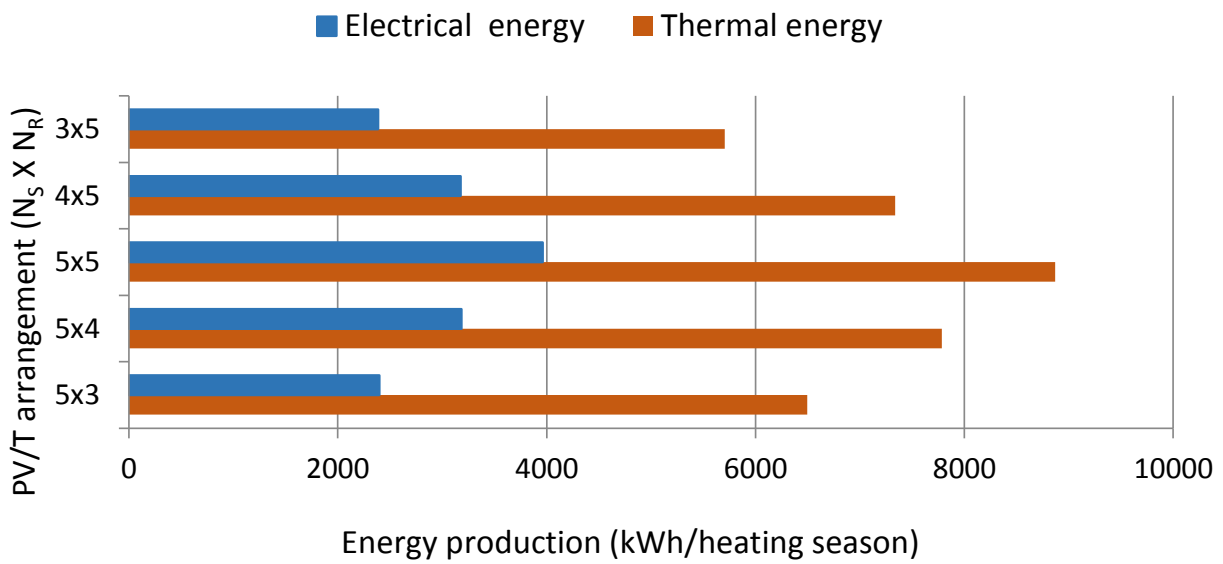

(b)

Figure 3-3: Electricity and thermal energy production of the heating season for different arrangements $\left(\mathrm{N}_{S} \times \mathrm{N}_{\mathrm{R}}\right), \mathrm{d}=38 \mathrm{~mm}$ and total air mass flow rate of $1.2 \mathrm{~kg} / \mathrm{s}$ (a) per row (b) for the whole array 


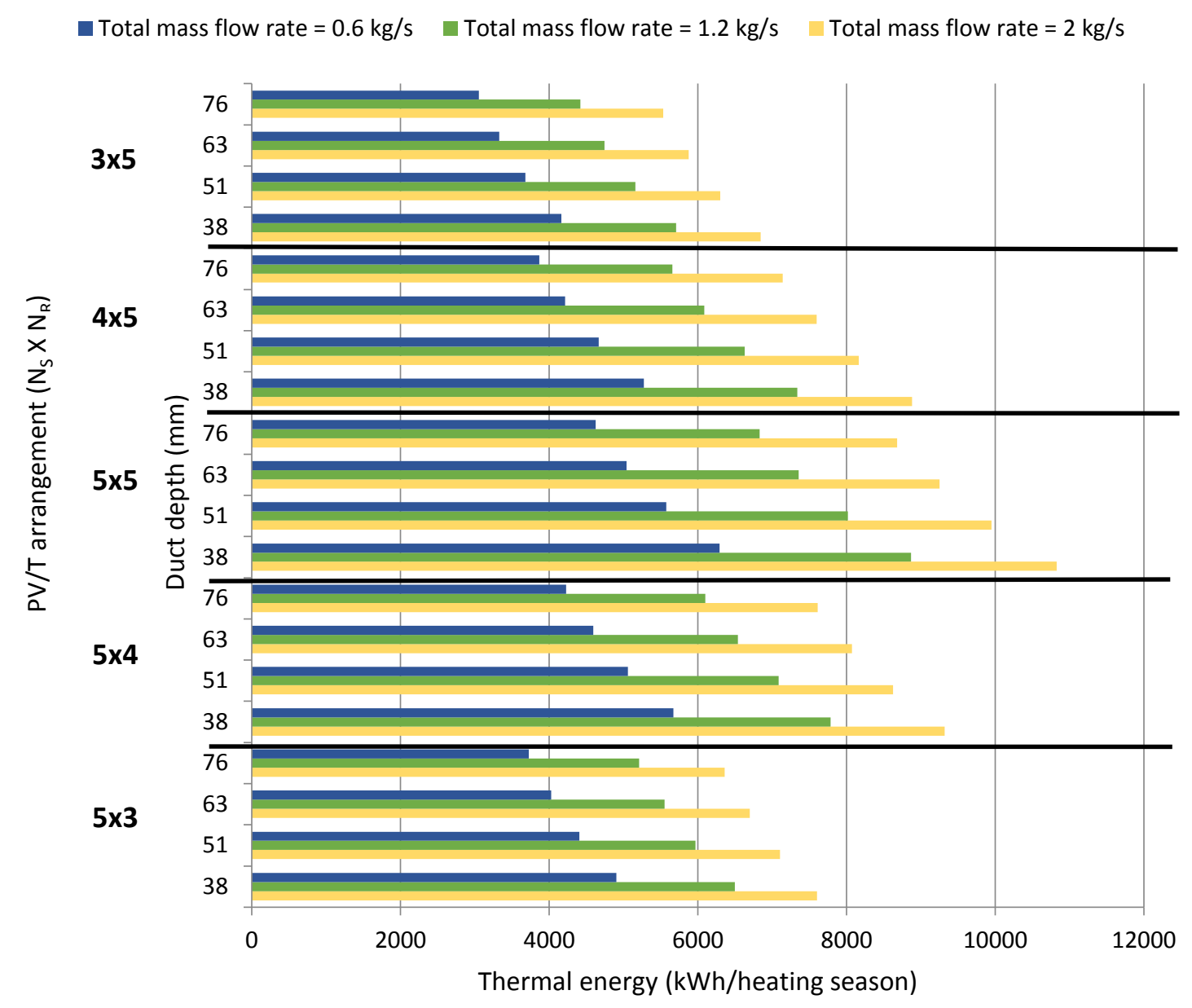

Figure 3-4: Total thermal energy production for the whole arrangements $\left(\mathrm{N}_{S} \times \mathrm{N}_{R}\right)$ with different duct depths and mass flow rates

Figure 3-5 shows the total thermal and electrical energy production for $3 \times 5,4 \times 5,5 \times 5,5 \times 4$ and $5 \times 3$ arrangements with different duct depths. The total mass flow rate was considered to be $1.2 \mathrm{~kg} / \mathrm{s}$ for each arrangement. The largest numbers of PV panels are 25 panels in the $5 \times 5$ array, so this configuration produces the highest quantity of electricity. The $5 \times 3$ array produces more thermal energy than the $3 \times 5$ array, but both of them produce almost the same amount of electricity. The comparison between the $5 \times 4$ and the $4 \times 5$ arrays has the same trend. 


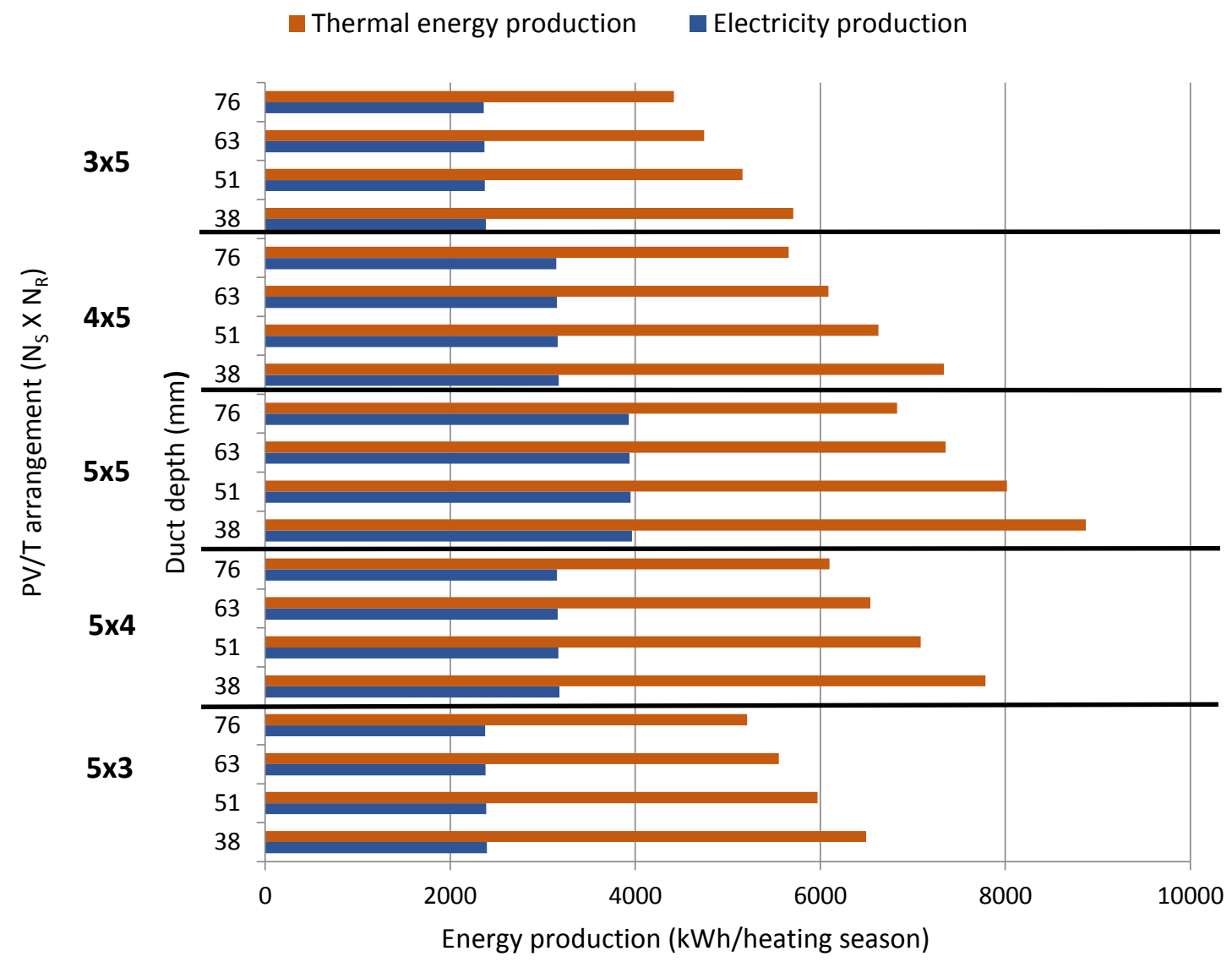

\section{Figure 3-5: Total electricity and thermal energy production of heating season for different arrangements with different duct depths, total air mass flow rate of $1.2 \mathrm{~kg} / \mathrm{s}$}

Figures 3-6, 3-7 and 3-8 show the overall PV/T system efficiency as a function of the duct depth, the air mass flow rate, and the configuration arrangements. The overall efficiency increases when the number of rows $N_{R}$ decreases (Figures 3-6 and 3-7). This is because, for the same total mass flow rate, the arrangement with less $\mathrm{N}_{R}$ has higher row mass flow rate. The row mass flow rate is obtained by dividing the total mass flow rate by the number of rows of the PV/T system. Consequently, the total energy production increases (see Figure 3-3(a)). The maximum achieved system efficiencies for the arrangements $5 \times 3,5 \times 4$ and $5 \times 5$ with total mass flow rate of $1.2 \mathrm{~kg} / \mathrm{s}$ were 54\%, 50\% and 47\%, respectively, as shown in Figure 3-6.

Figure 3-7 represents the overall efficiency of PV/T system for arrangements with the same total area of $18.6 \mathrm{~m}^{2}$ but different $\mathrm{N}_{S}$ and $\mathrm{N}_{\mathrm{R}}$ (the total number of PV/T panels for both systems is 15). The most efficient system is to have $\mathrm{N}_{S}$ higher than $\mathrm{N}_{R}$. The $5 \times 3$ configuration is $9.3 \%$ more efficient than the $3 \times 5$ configuration. 
Figure 3-8 shows the impact of the total air mass flow rate on the overall PV/T system efficiency. It shows that higher mass flow rates lead to better efficiency. Moreover, when the duct depth is smaller, the electricity and the thermal energy production slightly grow (see Figures 3-9 and 3-10). Therefore, the overall efficiency goes up.

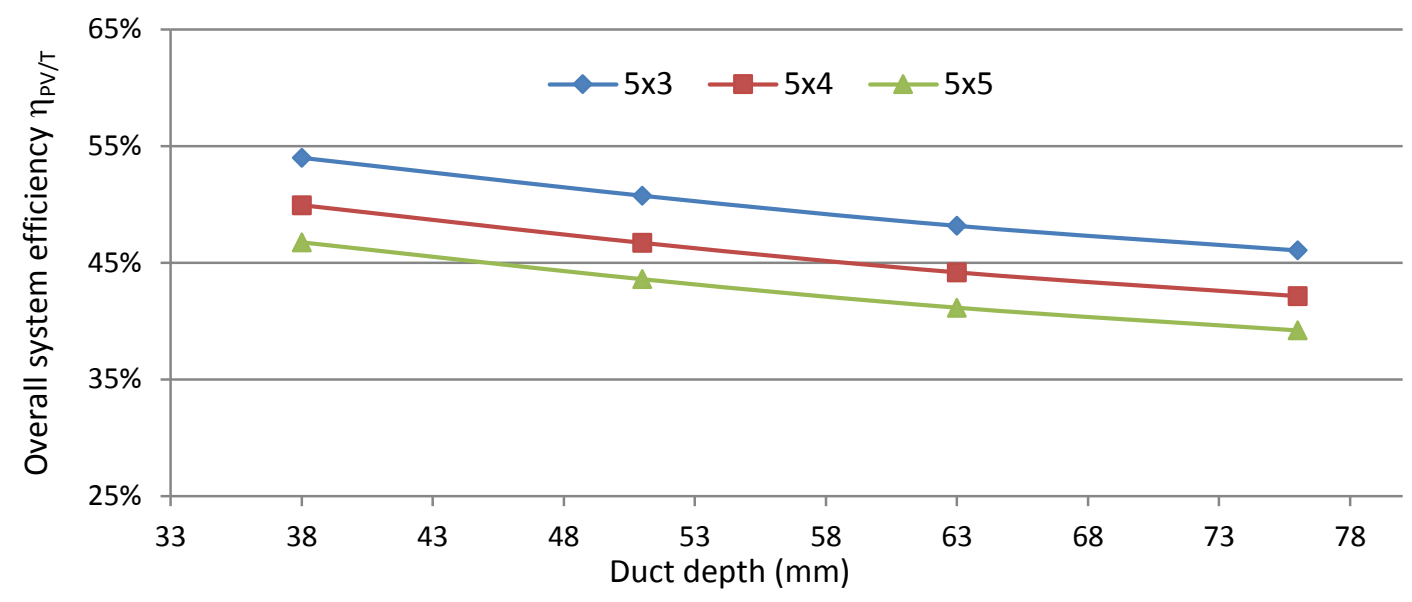

Figure 3-6: Overall PV/T system efficiency for different configurations with different duct depths, total air mass flow rate of $1.2 \mathrm{~kg} / \mathrm{s}$

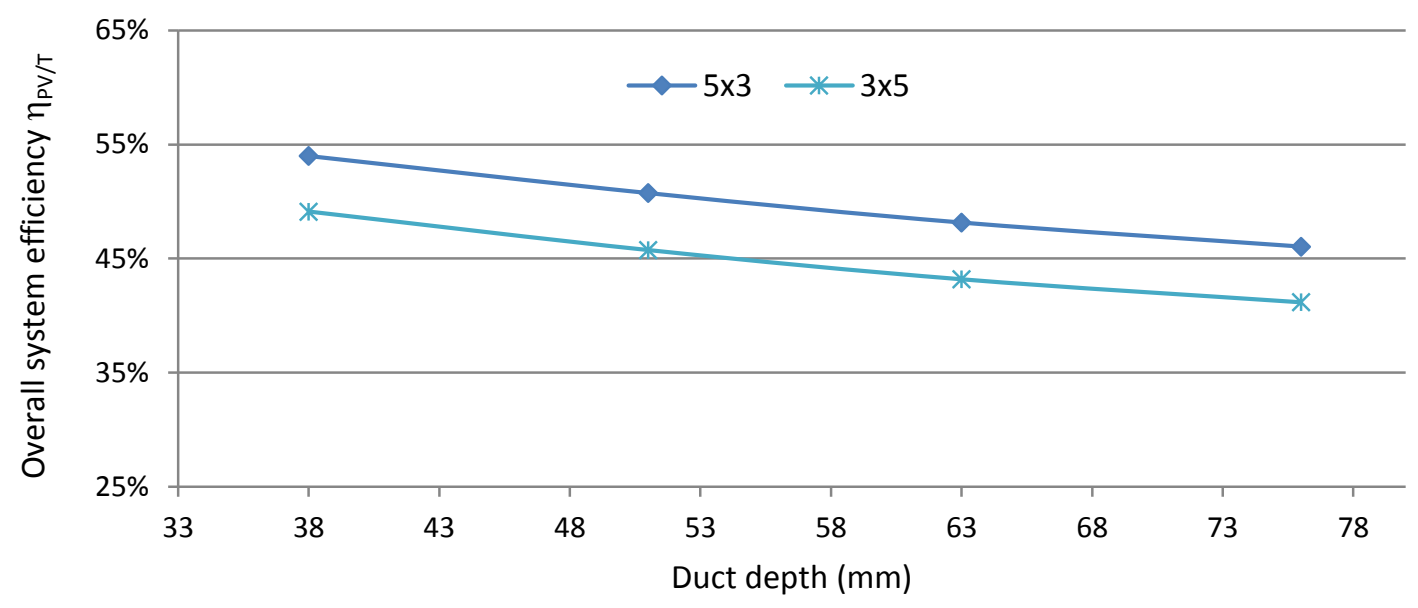

Figure 3-7: Overall PV/T system efficiency for $5 \times 3$ and $3 \times 5$ arrangements with different duct depths, total air mass flow rate of $1.2 \mathrm{~kg} / \mathrm{s}$ 


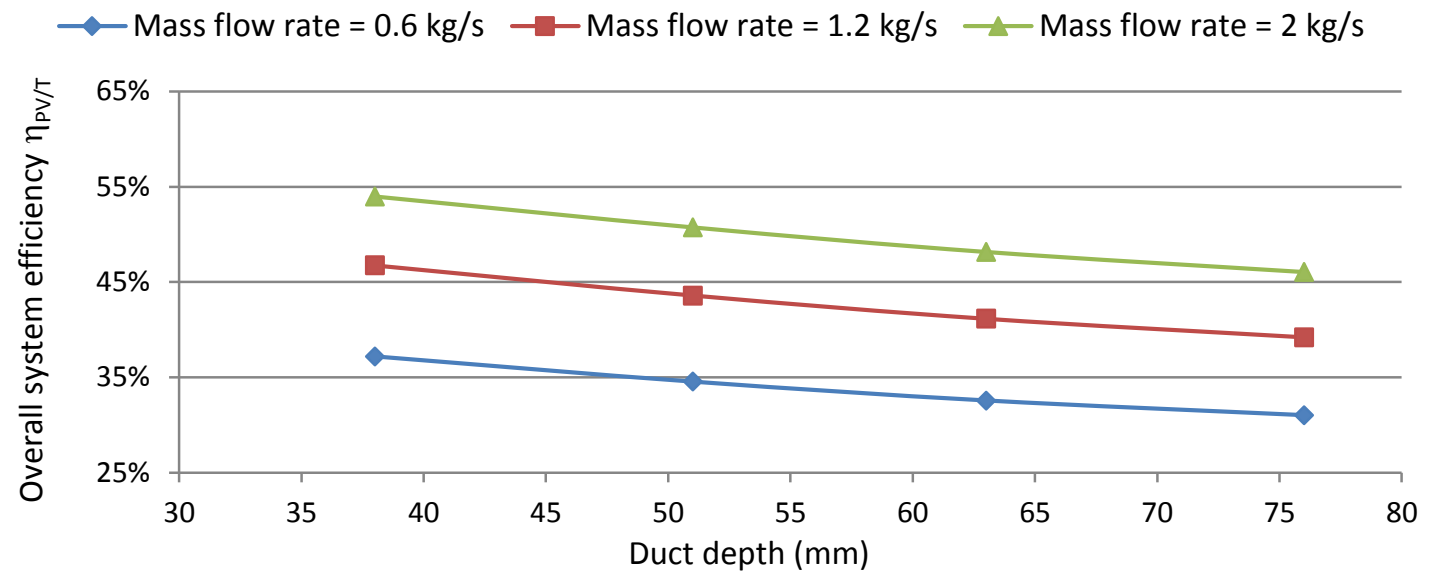

\section{Figure 3-8: Overall PV/T system efficiency with different total mass flow rates and different duct depths, $5 \times 5$ arrangement}

Based on this analysis, the arrangment of $5 \times 5$ was selected to be implemented on the full scale test facility of building integrated photovoltaic/thermal (BIPV/T) collector coupled with air source heat pump and thermal storage (a full description of the test hut facility will be provided in Chapter 6). Figure 3-9 shows the total thermal energy produced for $5 \times 5$ arrangement with different total mass flow rates and different duct depths for the heating season. The generated thermal energy grows dramatically until the total mass flow rate reaches $5 \mathrm{~kg} / \mathrm{s}$, amounting to around 14000 $\mathrm{kWh} / \mathrm{h}$ ating season. For greater mass flow rate values, the evolution of the thermal energy production is more gradually.

Figure 3-10 shows the total electricity produced for $5 \times 5$ arrangement with different total mass flow rates and different duct depths. Increasing mass flow rate leads to more heat removed from PV panels; consequently, the production of electricity goes up to the value of 4050 $\mathrm{kWh} /$ heating season. This is due to the improvement of the PV panels efficiencies. For a higher mass flow rate, the electricity production changes very slightly. In Figures 3-9 and 3-10, it is noticed that the duct depth has slight effect on the thermal energy and electricity production. The yield of the thermal energy is high with low duct depth. This is because of higher heat transfer coefficient for the flowing air inside the duct and consequently more electricity production from PV panels with cooler PV temperatures. However, there is a trade-off between maximizing the heat recovered from the PV panels (increase air mass flow rate and reduce duct depth) and pressure drop along the PV/T duct. The present analysis does not consider the energy required by an extra fan to drive the air inside the PV/T system. The pressure drop calculation will be presented in 
Chapter 6. It is important to consider the required fan power for forced ventilation air inside the duct.

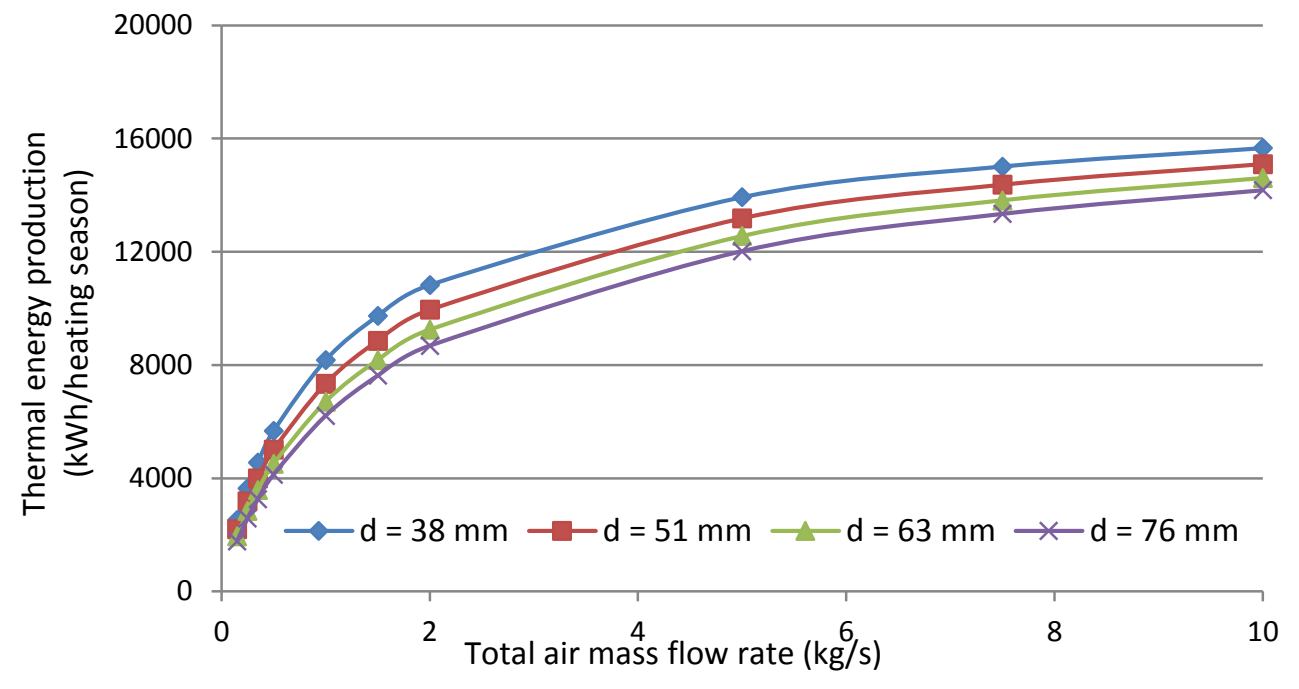

Figure 3-9: Total thermal energy production recovered from PV/T systems of the heating season for $5 \times 5$ arrangements with different total air mass flow rate and different duct depth

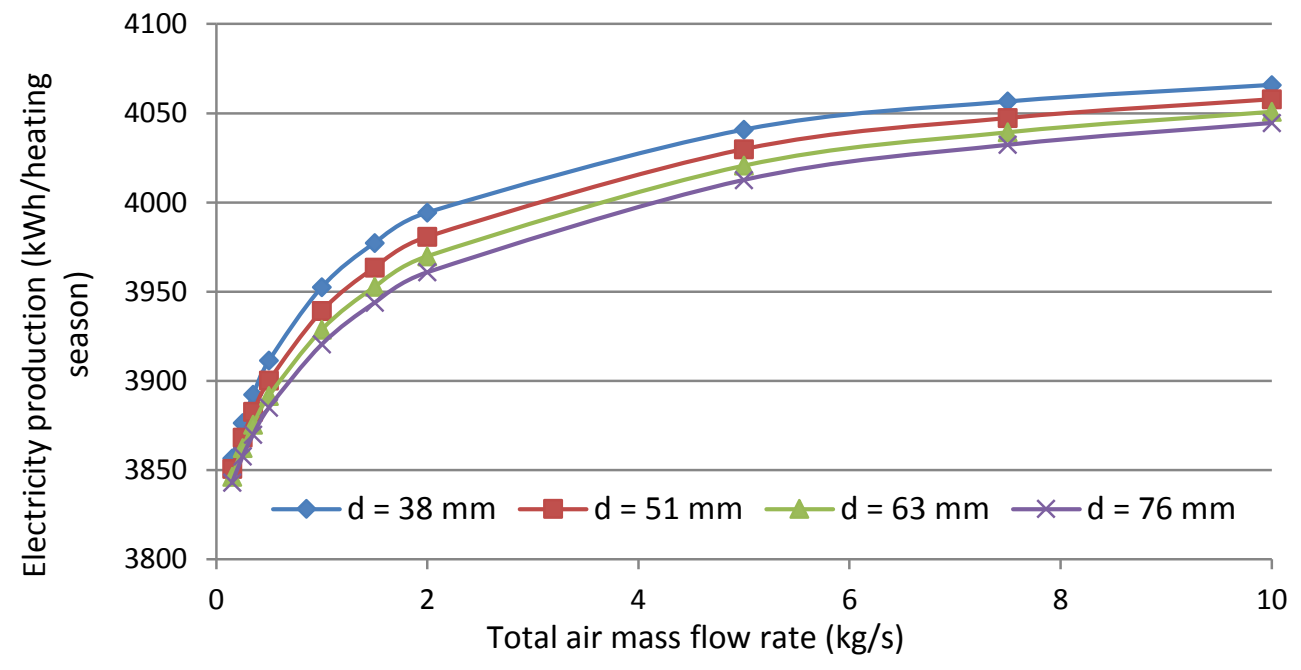

Figure 3-10: Total electricity production recovered from PV/T systems of the heating season for $5 \times 5$ arrangements with different total air mass flow rate and different duct depth 


\subsection{Building Integrated Photovoltaic-Thermal Collector system (BIPV/T)}

The presented PV/T model in Section 3.2 was a simple model for not integrated PV/T system as a building component. One of the objectives of this thesis is to model and simulate building integrated PV/T systems with air source heat pump. Therefore, the model needs to include a building envelope effect, which is usually available in an advanced simulation tool that has a detailed building envelope model. When the PV/T collector is modeled as a part of the building envelope, the thermal interaction between the PV/T system and the building is taken into account. In this case, there is exchange between parameters of both BIPV/T collector and building envelope during the simulation. In addition, the benefit of using a simulation tool is to allow a solar component (here the PV/T collector) to be part of the whole energy model which includes heating load, cooling load, temperature profiles for different zones, thermal energy storage, etc. of a building.

\subsection{Energy simulation program: TRNSYS}

TRNSYS is a visual based software used to model and simulate the behavior of transient energy systems for broad applications such as solar systems, HVAC systems with advance design features (e.g., natural ventilation, slab heating), fuel cells, and anything requires dynamic simulation (TRNSYS 17, 2012). The model consists of individual components, which represent one part of the overall modeled system. Each component (recognized as "TYPE") has its FORTRAN subroutine program, which is compiled into a Windows Dynamic Link Library (DLL) file. The DLL-based structure allows the user to modify an existing type and create a new custom component model in case that the current TRNSYS modules cannot simulate certain features. The types require time-independent PARAMETERS and time-dependent INPUTS, and generate OUTPUTS. During the simulation, the parameters remain constant. A given output from a type can be used as input for another type. The whole energy model consists of a number of types that are connected and interacted with each other. Figure 3-11 shows the types connection to formulate a TRNSYS model. 


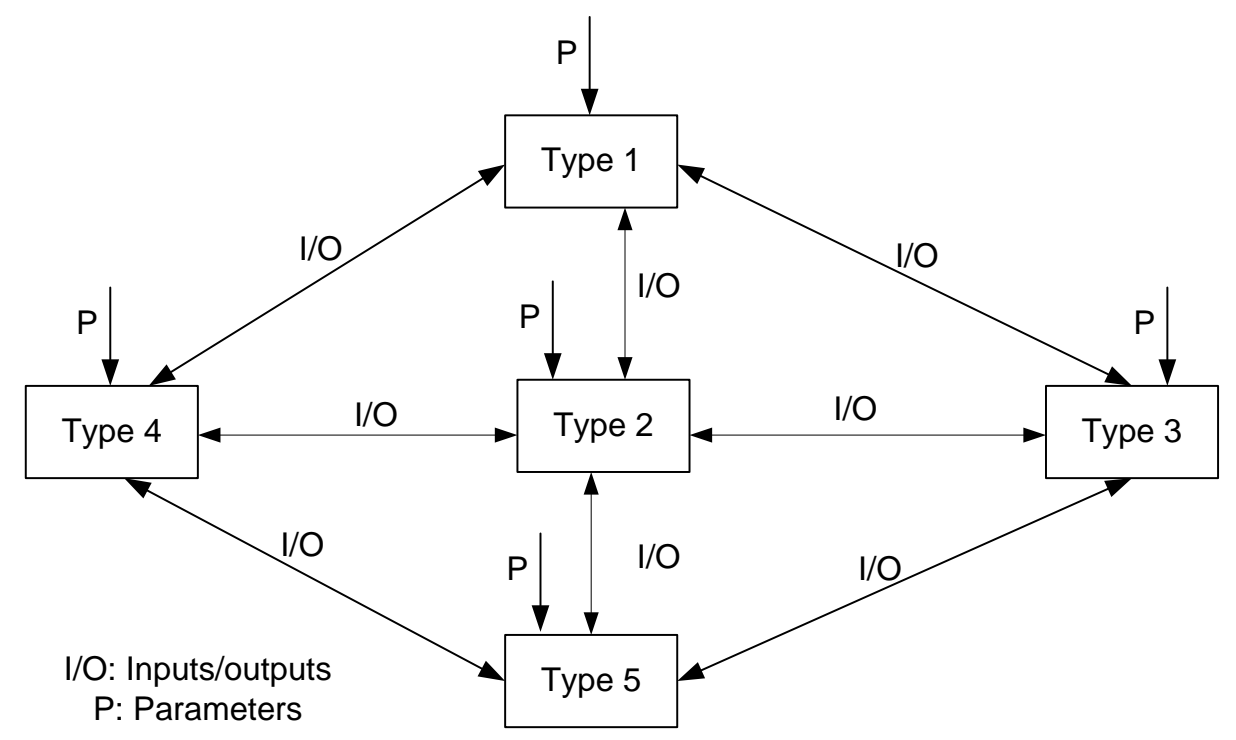

Figure 3-11: TRNSYS type's connections creating a model

\subsubsection{Existing BIPV/T component in TRNSYS}

This section presents the existing BIPV/T components in the standard and Thermal Energy System Specialists (TESS) libraries. The building integrated PV/T Types are available in Electrical library. Figure 3-12 shows the classification of the existing BIPV/T Types in TRNSYS 17.

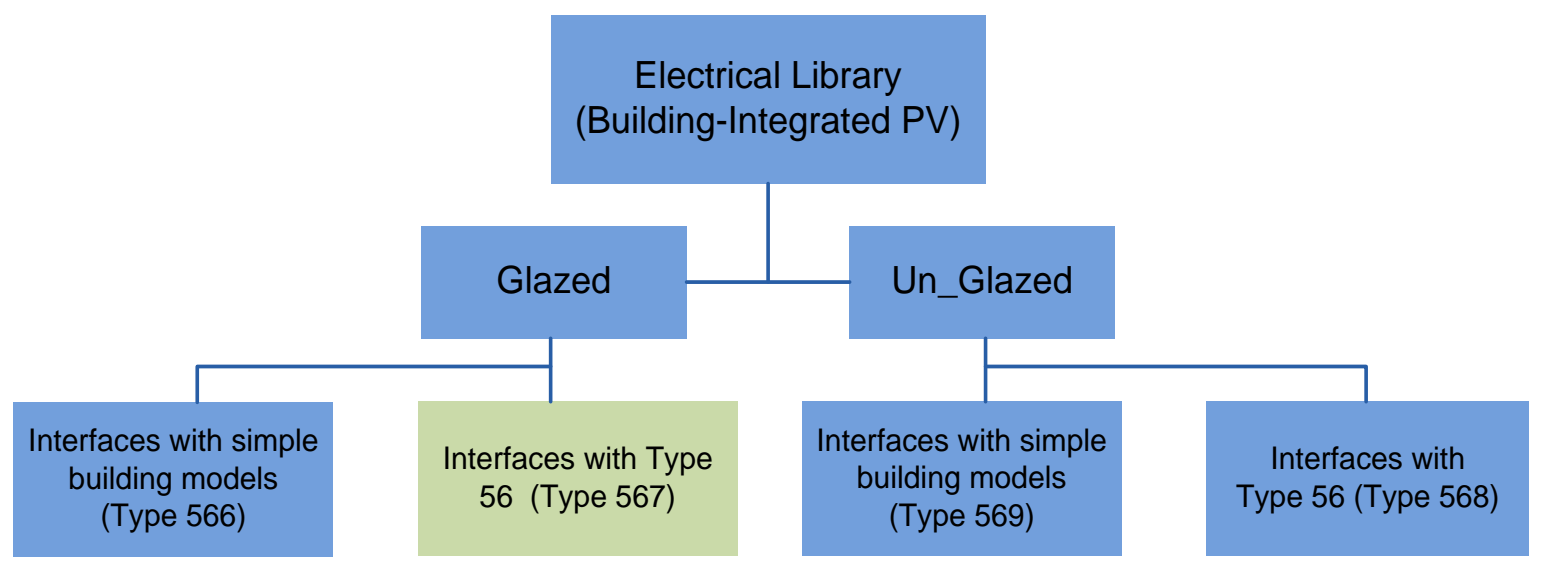

Figure 3-12: Building integrated PV/T Types in TRNSYS 17

Both Types 566 and 567 are described as glazed collectors. TRNSYS 17 is pointing out to a glass cover in contact (transparent cover) with the PV cells as glazing. The standard PV modules are covered with a sheet of glass. This cover layer serves several purposes as mechanical rigidity, 
impact resistance, optical transparency, electrical isolation of the solar cell circuit, and outdoor weather protection (King et al., 1998). In addition, the cover glass plays a significant role to minimize the top losses, which mainly occur due to wind velocity (Zondag, 2008).

Figure 3-13 shows a schematic of the PV/T system used in Type 566 and Type 567. The thermal models of both Types (566 and 567) were developed by energy balances at the cover surface, PV surface, upper air channel surface, and lower air channel surface. The mathematical details are available in TRNSYS TESS models documentation (TRNSYS17, 2012). Based on the mathematical description, the thermal resistance network for both Types is shown in Figure 3-14.

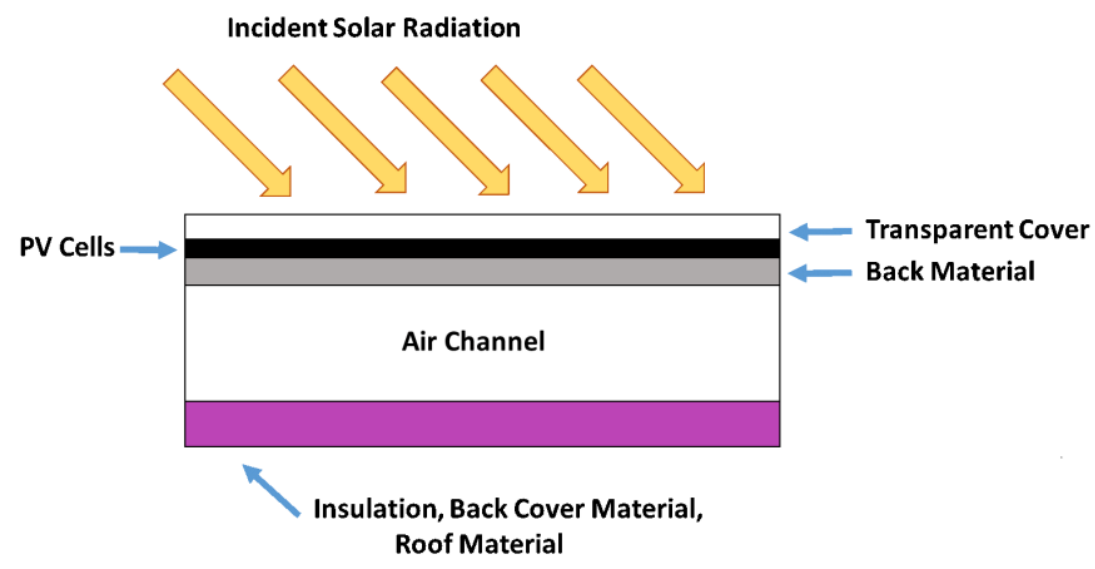

Figure 3-13: A schematic of PV/T system used in Type 566 and Type 567 (TRNSYS17, 2012) 


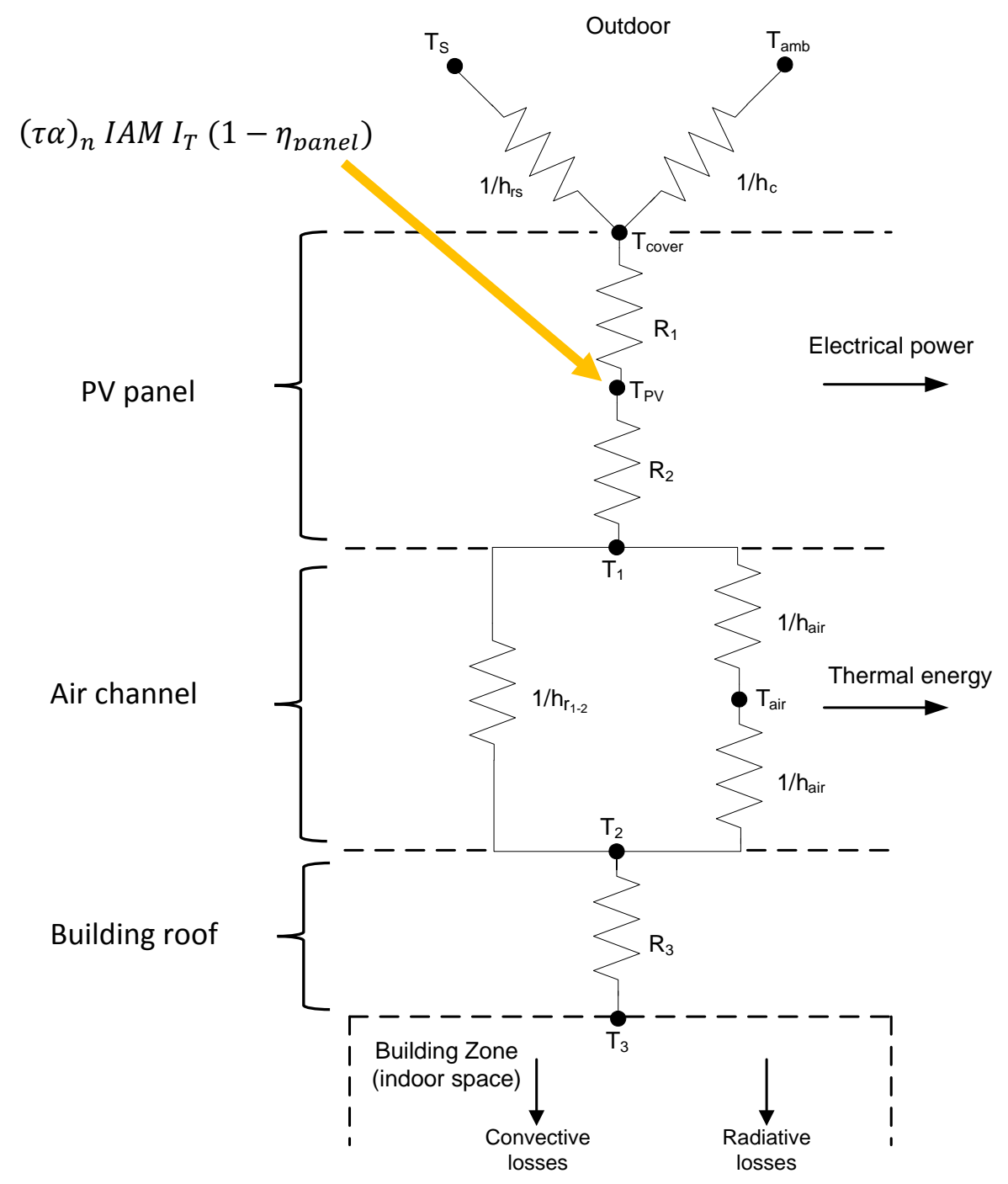

Figure 3-14: Thermal resistance for energy balance of BIPV/T in TRNSYS (Type 566 and Type 567)

However, the way to calculate the temperature of the back surface of the collector (zone air/collector interface temperature, $T_{3}$ ) is different. In Type 566, there is an extra equation at the back collector surface to calculate the back surface temperature; this model operates with simple building models that can provide the temperature of the zone air on the backside of the collector. In Type 567, the temperature of the back surface of the collector is provided by the detailed building model (Type 56). Again, since the objective is to simulate the whole system of building integrated PV/T system with an ASHP within a building (i.e., the model is connected to Type 56), Type 567 was selected. 


\subsubsection{Type 567 modifications}

One of the key factors in TRNSYS is that the source codes of the component models are available for users and could be modified to fit the user's specific needs. After checking the source code (FORTRAN code) of Type 567, several changes were made. Some changes were based on the developed PV/T model in Section 3.2.

\subsubsection{Absorbed solar radiation of PV panels}

The electricity yield from PV cells is affected by the amount of incident solar radiation and its angle. The total solar radiation reaching the PV panels comprises of beam, sky diffuse, and ground-reflected components. The absorption, transmission, and reflection through the protective cover of PV panel are affected by the beam incidence angle, effective sky diffuse angle, and effective ground-reflected angle (John and William, 2006; Soto et al., 2006). These effects are expressed in terms of the Incident Angle Modifier (IAM), which is defined for all solar radiation components (beam, sky, ground-reflected) as "the ratio of the transmittance-absorptance product at given angle to the transmittance-absorptance product at normal incident". The incident angle has considerable effect in early morning and late afternoon (Candanedo et al., 2011).

\subsubsection{Incident Angle Modifier (IAM) modification}

Equation (3-26) has been used to calculate IAM in Type 567. This equation is used for a solar collector. The calculation of the incident angle modifier for the PV module differs from that of solar collector due to direct contact of the glazing to the PV cell surface (John and William, 2006).

$$
\operatorname{IAM}(\theta)=\frac{(\tau \alpha)}{(\tau \alpha)_{n}}=1-b_{0}\left(\frac{1}{\cos \theta}-1\right)
$$

King et al. (1998a), Fanney et al. (2002), and Sandia Laboratories (2002) presented a correlation for incident angle modifier for a PV panel in the form of fifth order polynomial equation (Equation 3-27). The coefficients of Equation (3-27) for four different PV cell types are listed in Table 3-2.

$$
\operatorname{IAM}(\theta)=\sum_{i=0}^{5} b_{i} \theta^{i}
$$


Table 3-2: IAM coefficients for four different PV cell type (Soto et al., 2006)

\begin{tabular}{|c|c|c|c|c|}
\hline $\begin{array}{c}\text { Coefficients } \\
\text { of Eq. (3-25) }\end{array}$ & Silicon thin film & Single-crystalline & Poly-crystalline & $\begin{array}{c}\text { Three-junction } \\
\text { amorphous }\end{array}$ \\
\hline $\mathrm{b}_{0}$ & 0.998980 & 1.000341 & 0.998515 & 1.001845 \\
\hline $\mathrm{b}_{1}$ & -0.006098 & -0.005557 & -0.012122 & -0.005648 \\
\hline $\mathrm{b}_{2}$ & $8.117 \mathrm{E}-04$ & $6.553 \mathrm{E}-04$ & $1.440 \mathrm{E}-03$ & $7.25 \mathrm{E}-04$ \\
\hline $\mathrm{b}_{3}$ & $-3.376 \mathrm{E}-05$ & $-2.730 \mathrm{E}-05$ & $-5.576 \mathrm{E}-05$ & $-2.916 \mathrm{E}-05$ \\
\hline $\mathrm{b}_{4}$ & $5.647 \mathrm{E}-07$ & $4.641 \mathrm{E}-07$ & $8.779 \mathrm{E}-07$ & $4.696 \mathrm{E}-07$ \\
\hline $\mathrm{b}_{5}$ & $-3.371 \mathrm{E}-09$ & $-2.806 \mathrm{E}-09$ & $-4.919 \mathrm{E}-09$ & $-2.739 \mathrm{E}-09$ \\
\hline
\end{tabular}

Soto et al. (2006) showed that King's model was mathematically simple and was based on experimental data from field test. Therefore, for any other cell types, specific constants of the incident angle modifier from manufacturer are required. IAM could be calculated by using Equations (3-28) to (3-31) (John and William, 2006).

$$
\begin{aligned}
& \theta_{r}=\sin ^{-1}\left(\frac{\sin \theta}{n_{2}}\right) \\
& (\tau \alpha)(\theta)=e^{-\left(K l / \cos \theta_{r}\right)}\left[1-\frac{1}{2}\left(\frac{\sin ^{2}\left(\theta_{r}-\theta\right)}{\sin ^{2}\left(\theta_{r}+\theta\right)}+\frac{\tan ^{2}\left(\theta_{r}-\theta\right)}{\tan ^{2}\left(\theta_{r}+\theta\right)}\right)\right]
\end{aligned}
$$

$n_{2}$ in Equation (3-28) is the refractive index related to the cover material. Table 3-3 shows average refractive indices of some cover materials.

Table 3-3: Average refractive index of some cover materials (John and William, 2006)

\begin{tabular}{|c|c|}
\hline Cover Material & Average $n_{2}$ \\
\hline Glass & 1.526 \\
\hline Polymethyl methacrylate & 1.49 \\
\hline Plyvinylfluoride & 1.45 \\
\hline Polyfluorinated ethylene propylene & 1.34 \\
\hline Polytetrafluoroethylene & 1.37 \\
\hline Polycarbonate & 1.60 \\
\hline
\end{tabular}

$(\tau \alpha)_{n}$ is calculated at normal incidence by substituting $\theta=0^{\circ}$ in Equation (3-29), which leads to the following equation:

$$
(\tau \alpha)_{n}=e^{-K l}\left[1-\left(\frac{n_{2}-1}{n_{2}+1}\right)^{2}\right]
$$

So, IAM for general method is: 


$$
\operatorname{IAM}(\theta)=\frac{(\tau \alpha)(\theta)}{(\tau \alpha)_{n}}
$$

Incident Angle Modifier must be calculated for beam, sky diffuse, and ground-reflected radiation substituting the beam incident angle, effective sky diffuse angle, and effective groundreflected angle in Equation (3-27) for King's model or in Equation (3-31) for the general method. Figure 3-15 shows the incident angle modifier as a function of incident angle by using King's model (Equation 3-27) and by using the general model (Equations 3-28 to 3-31). There is a slight difference for small incident angles but the differences grow to be obvious for high values of incident angles.

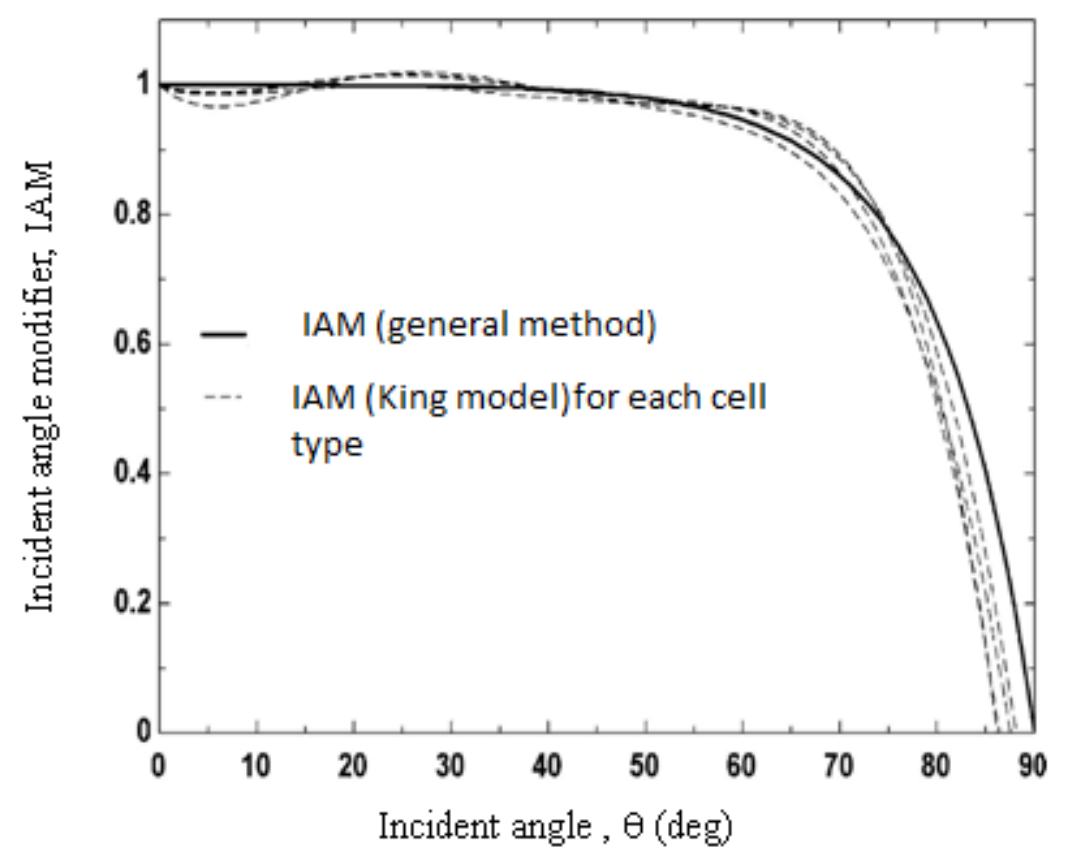

Figure 3-15: IAM as a function of incident angle for King Model and general method (John and William, 2006; Soto et al., 2006)

Type 567 has been modified to consider IAM calculation for PV panels (for both King's model and the general method) instead for solar collector. Also some other modifications related to Nusselt and Ryenolds number calculations have been done. Therefore, two types have been created to include these changes, Type 289 and Type 298. Type 289 uses King's model, which is based, as is mentioned earlier, on experimental results while Type 298 uses the general method that can be used for any type of PV cells. The extinction coefficient, $K$, was defined as a parameter in Type 
298, a value of $4 \mathrm{~m}^{-1}$ was used for glass as the cover material of the PV/T collector in the TRNSYS model in this thesis.

\subsubsection{Reynolds number and Nusselt number modification}

Equation (3-32) is used to calculate Reynolds number in Type 567. The flow rate of fluid through the channel of PV/T system is determined for a circular cross section.

$$
R e=\frac{4 \dot{m}}{\pi D_{h} \mu}
$$

The modified Reynolds number (Type 289 and Type 298) is the same Reynolds number defined in Equation (3-18).

Nusselt number used in Type 567 is:

$$
\begin{array}{ll}
(R e<2300): N u=3.66 & \text { For laminar flow in the channel } \\
(R e \geq 2300): N u=0.023 \operatorname{Re}^{0.8} \mathrm{Pr}^{n} & \text { For turbulent flow in the channel }
\end{array}
$$

Where $\mathrm{n}=0.4$ for heating and $\mathrm{n}=0.3$ for cooling

Equation (3-33), which is used for fully developed laminar flow in circular cross section tubes (Kays and Crawford, 1993), is replaced by Equation (3-15).

Equation (3-17), which was obtained for fully developed turbulent flow with one side heated and the other side insulated, was used in Type 298 and Type 289 instead of Equation (334). The TRNSYS component for BIPV/T system represents only one panel. Since each row of the BIPV/T array comprises of BIPV/T collectors connected in series the effect of entrance was considered just for the first panel. In this case, a new parameter was added to Type 298 and Type 289, defined as LOC (Location Of the Collector). Kays and Crawford (1993) shows that for $\mathrm{L} / \mathrm{D}_{\mathrm{h}}>6$, Nusselt number could be considered fully developed. The typical range of length and width of PV panels are $\sim 0.8-0.99 \mathrm{~m}$ and 1.3-1.95 m, respectively (Transition Chepstow Energy Group, 2014). If the channel depth of $76 \mathrm{~mm}$ is considered, then the range of $\mathrm{L} / \mathrm{D}_{\mathrm{h}}$ is 5.6-6.7, which then justifies this assumption. 


\subsubsection{Equation block: Top convective heat loss coefficient}

One of the inputs in PV/T type in TRNSYS is top surface heat loss coefficient, which is the convective heat transfer coefficient from the cover surface to the ambient air. TRNSYS does not have a type to calculate this coefficient. Several different equations were used to calculate the top surface convective heat transfer coefficient as a function of wind speed. The effect of wind speed on top surface heat losses due to convection is significant for BIPV/T collector without cover, while for BIPV/T collector with glass cover, the influence of external heat transfer coefficient is less essential. McAdams (John and William, 2006) reported the following dimensional equation for the convection coefficient:

$$
\mathrm{h}_{\mathrm{c}}=5.7+3.8 \mathrm{~V}_{\mathrm{w}}
$$

It is not clear if the natural convection effects are included in Equation (3-35) and the wind may not always be parallel to the surface. For this reason, Watmuff et al. (John and William, 2006) reported that Equation (3-36) should be used:

$$
\mathrm{h}_{\mathrm{c}}=2.8+3.0 \mathrm{~V}_{\mathrm{w}}
$$

So, an equation block was used in modelling in TRNSYS to calculate the top surface convective heat transfer coefficient for a BIPV/T system using Equation (3-36).

\subsection{Modeling of opaque BIPV/T system within a building envelope}

The modified TRNSYS BIPV/T Type 298 was used to model opaque BIPV/T system with a basic model house (Type 56). The TRNSYS model was applied to investigate the impact of different parameters on BIPV/T performance. The house is a single zone house with volume of $900 \mathrm{~m}^{3}$. The south oriented roof area is $53.55 \mathrm{~m}^{2}, 45^{\circ}$ tilted angle. The indoor set point was $21^{\circ} \mathrm{C}$ for heating and $23^{\circ} \mathrm{C}$ for cooling. The insulation material for roof and external walls were R-40 and R-30 respectively. Based on the results from Section 3.2, the more PV/T collectors connected in series for an array, the higher the outlet temperature of a row. However, the number of BIPV/T collectors is restricted by the roof area. The roof area of this single house was selected to integrate $5 \mathrm{PV} / \mathrm{T}$ panels in a row. In this case, each PV/T panel was considered as a single thermal air node integrated on the roof during the simulation. 
There are five different radiation-processing modes available in TRNSYS weather data type to calculate the radiation components (TRNSYS17, 2012):

- Mode 1: Isotropic sky model

- Mode 2: Hay and Davies model

- Mode 3: Reindl model

- $\quad$ Mode 4: Perez 1988 model

- Mode 5: Perez 1999 model

The total radiation on a tilted surface is the summation of the beam component on a titled surface and the diffuse components on a tilted surface; the diffuse radiation refers to sky diffuse component and ground reflected component:

$$
I_{T}=I_{T, b}+I_{T, s d}+I_{T, g}
$$

All five modes above use the same procedures to compute the beam and ground reflected components on an inclined surface. The only difference is in the calculation of the sky diffuse radiation on a tilted surface. All modes, except Mode 1, give approximately similar results for the total radiation on a sloped surface and are recommended for general use. The isotropic sky model (Mode 1) is not recommended for general use. However, it is still included in TRNSYS 17 to permit consistency with simulations performed with earlier versions of TRNSYS. Mode 5, Perez 1999 model, was added in TRNSYS version 17 (TRNSYS17, 2012). Since Mode 5 is the most updated mode for tilted surface radiation calculations, it was used in the simulation.

\subsubsection{Thermal interaction between BIPV/T type and building model (Type 56) during the simulation}

In order to integrate a PV/T collector on a roof, the user defines the lower air channel surface of the PV/T model as a boundary wall of a specific zone in the building (the zone which its roof is the PV/T collector itself). Figure 3-16 shows the interaction between a BIPV/T Type and Type 56. During the simulation, which is based on iterative approach, the BIPV/T model calculate $\mathrm{T}_{2}$, then Type 56 use $\mathrm{T}_{2}$ as boundary temperature and calculate the wall temperature, $\mathrm{T}_{3}$, at the inside surface (collector back interface). This calculated value is sent back to the BIPV/T model as input parameter. Again, the BIPV/T Type re-calculates $\mathrm{T}_{2}$. The procedure continues until 
temperatures calculated at a given iteration are approximately equal to the values calculated in the previous step.

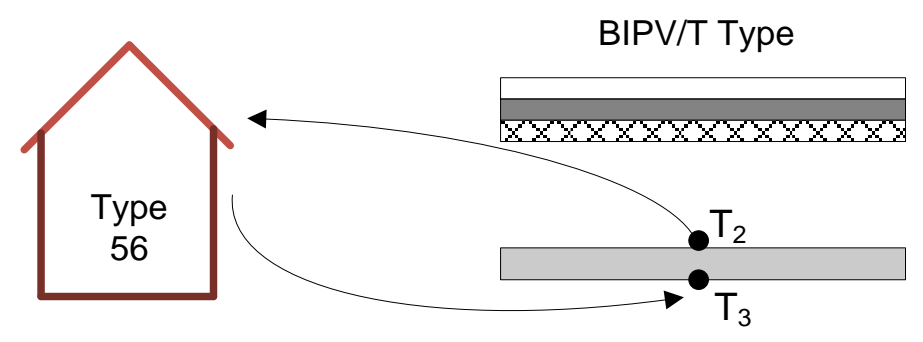

Figure 3-16: Thermal interaction between Type 56 and Type 567

\subsubsection{Impact of different parameters on BIPV/T performance}

It is known that a PV panel electricity output is affected by weather and the availability of solar radiation during the simulation. For PV/T systems, the generated electricity is also affected by the mass flowrate of air moving in the channel underneath the PV panels. Increasing mass flow rate leads to more heat recovered from PV panels; consequently, the production of electricity goes up. This is due to the improvement of the PV panel efficiencies. Figure 3-17 illustrates the hourly variation of a PV/T panel temperature and its electrical efficiency for a typical day in winter $\left(\right.$ January $21^{\text {st }}$ ). This day is selected for its high solar radiation and low ambient outdoor temperature. It is clear that PV temperature is reduced with increasing air mass flow rate since more air volume is available to remove more heat from the PV cells. Correspondingly, the electrical efficiency of the PV panel becomes higher.

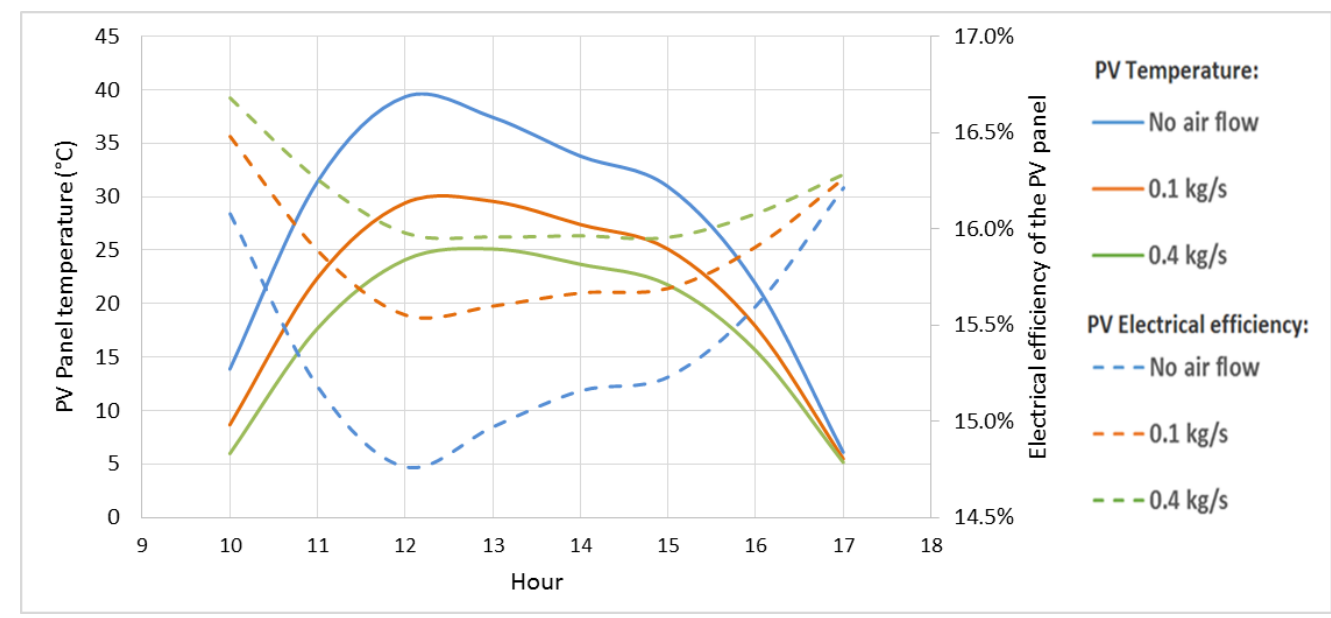

Figure 3-17: Hourly variation of a PV panel temperature and its electrial effiicency for a typical day in winter (January $21^{\text {st }}$ ) 
The results show that the amount of electrical energy generated from each PV panel and the electrical efficiency also depend on the panel position in a row (see Figures 3-18 and 3-19). For $0.1 \mathrm{~kg} / \mathrm{s}$, the first PV panel has the highest efficiency $(16.01 \%)$ and produces $1448 \mathrm{Wh}$ of electricity, while the fifth PV panel has the lowest value of efficiency (15.80\%) and generates 1433 Wh of electrical energy. Since the PV panels are cooled by the flowing air which becomes warmer as it moves along the channel under the PV panels, the temperature of the first PV panel is the lowest while the last PV panel temperature is warmer approximately by $5^{\circ} \mathrm{C}$ as shown in Figure 3-20. In other words, air extracts more heat from the first PV panel than that from the last PV panel.

When the row mass flow rate is increased from 0.1 to $0.4 \mathrm{~kg} / \mathrm{s}$, the electrical yield from the first panel is also increased from $1448 \mathrm{Wh}$ to $1476 \mathrm{Wh}$ corresponding to electrical efficiencies of $16.01 \%$ and $16.24 \%$, respectively; while for the non ventilated BIPV/T system (no air flow rate), each panel produces the same amount of electricity (1398 Wh) corresponding to $15.5 \%$ electrical efficiency.

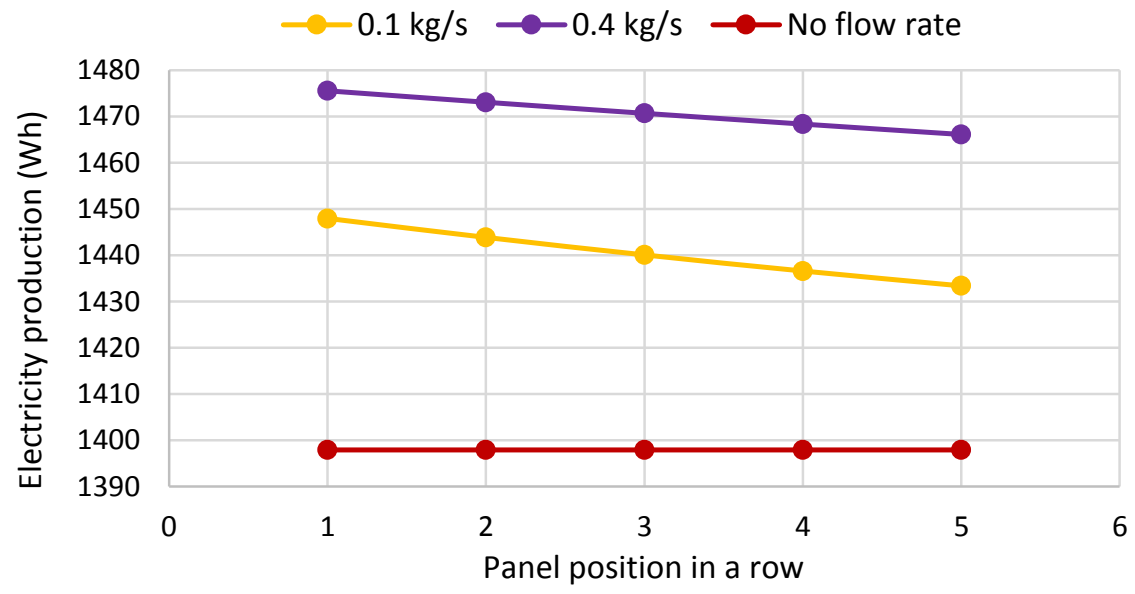

Figure 3-18: The effect of panel position in a row on total electricity production for a typical winter day $\left(\right.$ January $\left.21^{\text {st }}\right)$ with different flow rate, with $\mathrm{d}=76.2 \mathrm{~mm}(3 \mathrm{in})$ 


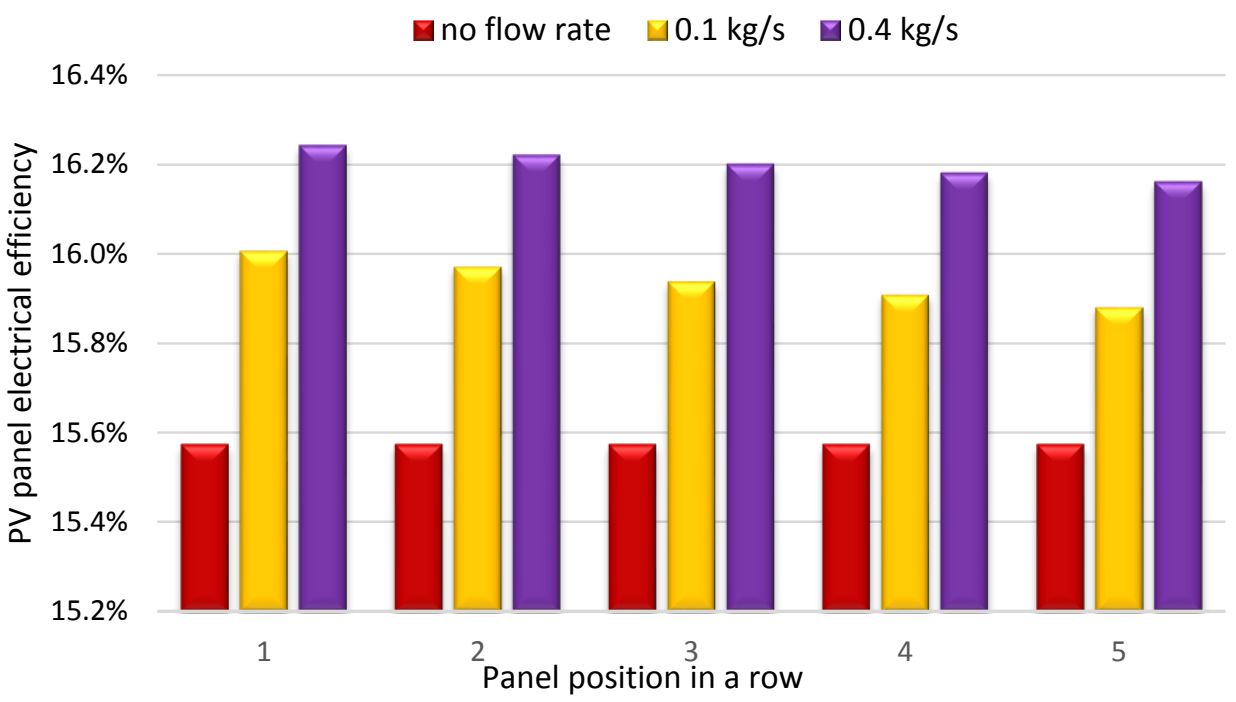

Figure 3-19: The effect of panel position in a row on PV panel electrcial efficiency for a typical winter day $\left(\right.$ January $\left.21^{\text {st }}\right)$ with different flow rate, with $\mathrm{d}=76.2 \mathrm{~mm}(3 \mathrm{in})$

$\square$ No flow rate $\square 0.1 \mathrm{~kg} / \mathrm{s} \square 0.4 \mathrm{~kg} / \mathrm{s}$

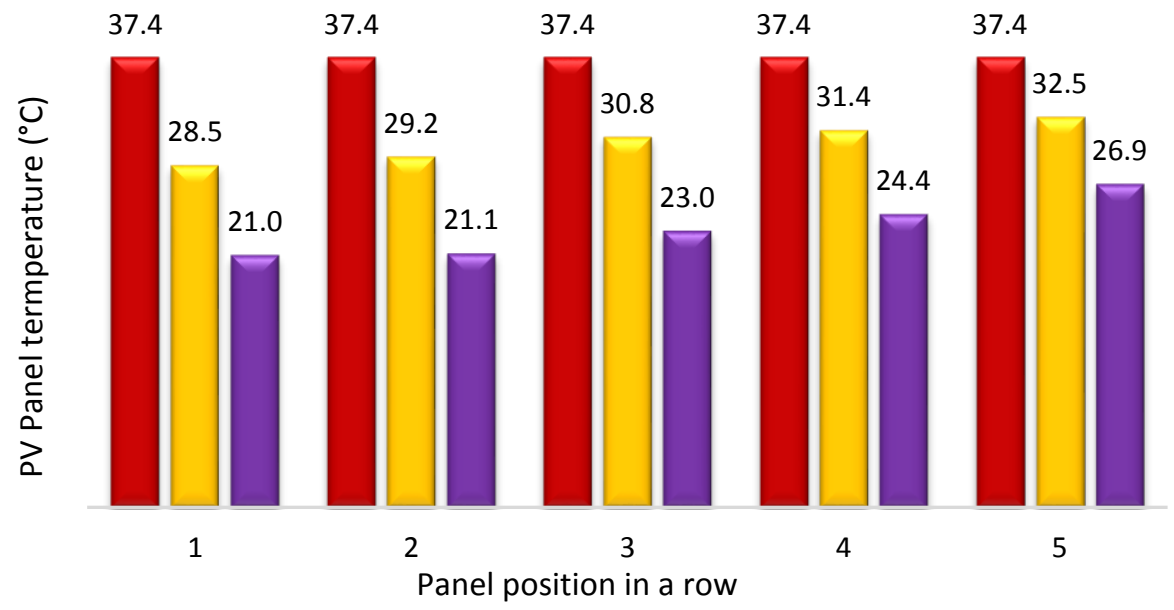

Figure 3-20: The effect of panel position in a row on PV panel temperature for a typical winter day $\left(\right.$ January $\left.21^{\text {st }}\right)$ with different flow rate, with $\mathrm{d}=\mathbf{7 6 . 2} \mathbf{~ m m ~}(3 \mathrm{in})$

As it was shown in Section 3.2 that increasing air mass flow rate results in significant increase in useful thermal energy obtaiend from the BIPV/T system. But, when the flow rate of the flowing air in the PV/T duct increases, the outlet air temperature declines rapidly as shown in Figure 3-21. The Figure shows that as the flow rate becomes very large, the temperature rise from 
inlet to outlet decreases toward zero. For combining a PV/T system with air source heat pump, the outlet air temperature from the PV/T array is important factor to improve the performance of the heat pump. It is desired to have air with high temperature. (More details will be discussed in Chapter 5).

The temperature of air from PV/T system is also influenced by wind velocity, ambient temperature, and solar radiation. Fig. 3-22 shows the outlet air temperature from the PV/T system based on TRNSYS simulation. It is shown from Fig. 3-22 that the ambient air temperature increases from $3.9^{\circ} \mathrm{C}$ to $9.09^{\circ} \mathrm{C}$ around noon for air mass flow rate of $0.4 \mathrm{~kg} / \mathrm{s}$, while at the same time of the day, it goes up to the value of $15.9^{\circ} \mathrm{C}$ for mass flow rate of $0.1 \mathrm{~kg} / \mathrm{s}$. For both cases, the average temperature of the PV panel is higher than the cover glass temperature and the back surface temperature of the PV panel. the reason is that the cells act as the absorber surface of the collector. since less heat removed from the PVT surfaces is linked to low flow rate, the temperatures of PV/T collector surfaces $\left(\mathrm{T}_{1}, \mathrm{~T}_{2}, \mathrm{~T}_{\mathrm{PV}}\right.$ and $\left.\mathrm{T}_{\text {cover }}\right)$ are higher for lower flow rate. The back surface temperature for both cases is a little bit higher than the zone temperture because the high insulation of the roof material (R-40).

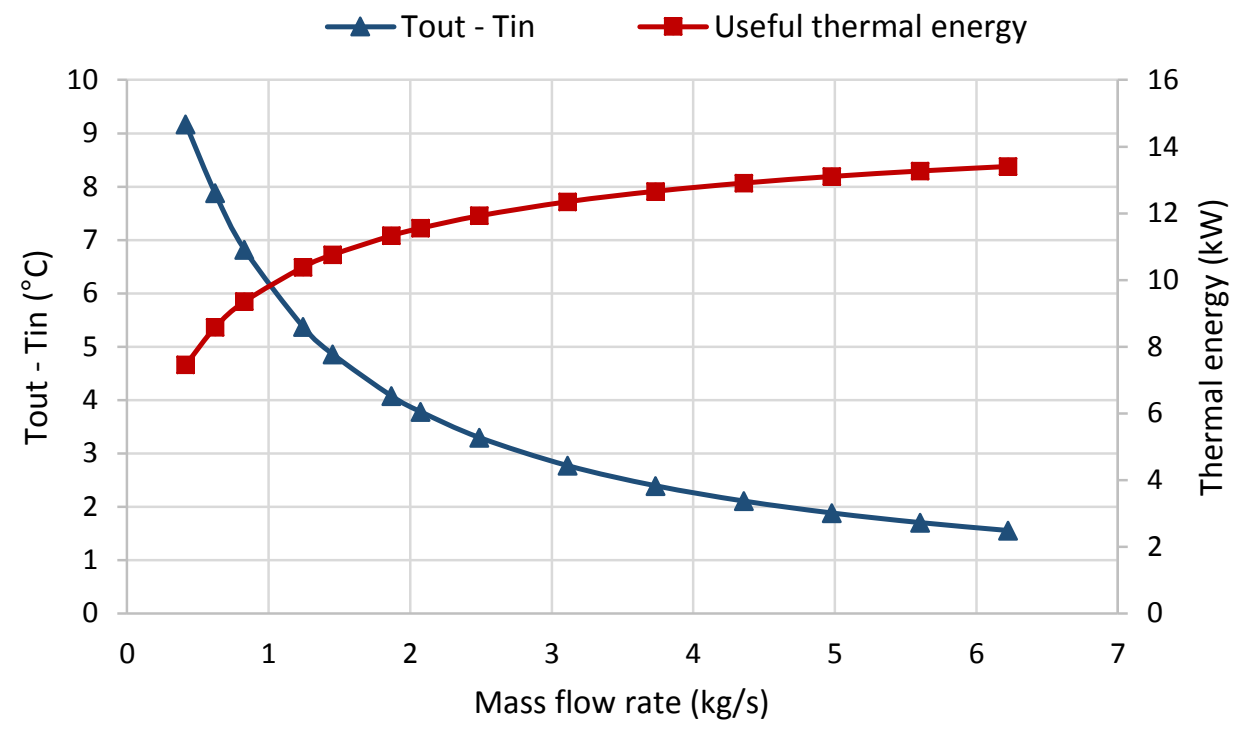

Figure 3-21: Effect of mass flow rate on the instantaneous useful thermal energy obtained from BIPV/T system and $\left(T_{\text {out }}-T_{\text {in }}\right)$ of air (winter 12 noon), January $21^{\text {st }}$ 


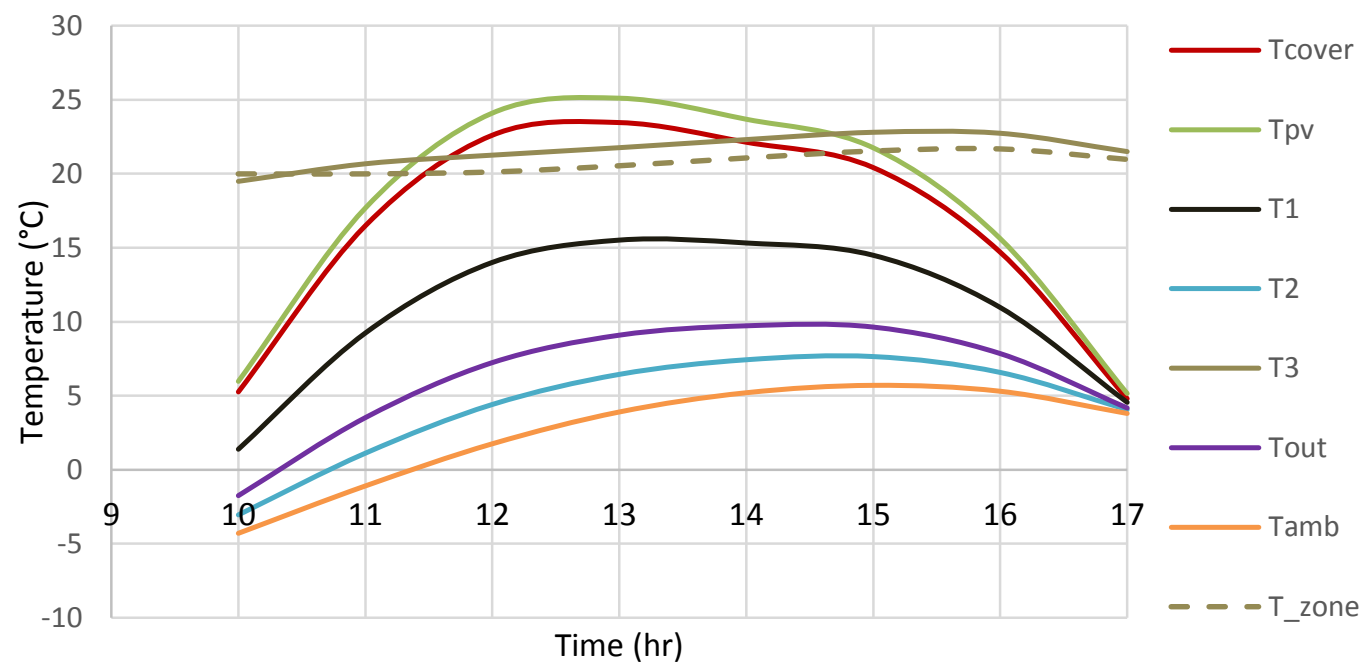

(a) $0.4 \mathrm{~kg} / \mathrm{s}$

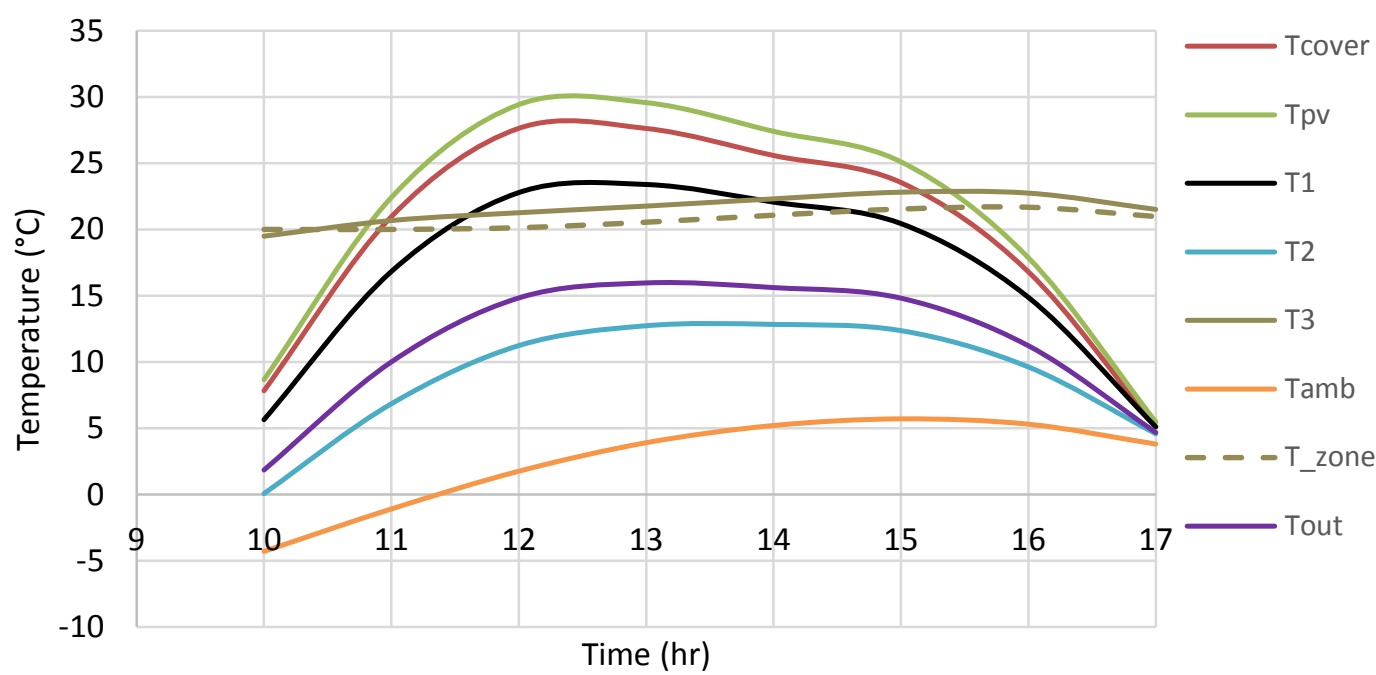

(b) $0.1 \mathrm{~kg} / \mathrm{s}$

Figure 3-22: Hourly variation of PV/T collectors surfaces temperatures (cover surface, PV surface, upper air channel surface, lower air channel surface, and back surface), outlet air temperature and zone temperature for (a) $0.4 \mathrm{~kg} / \mathrm{s}$ (b) $0.1 \mathrm{~kg} / \mathrm{s}$ 


\subsection{Summary and conclusion}

This chapter presented a performance analysis of different photovoltaic-thermal collector system arrangements. For the same total number of PV/T panels used in one array and same total mass flow rate, it is better to have $N_{S}$ greater than $N_{R}$ in order to produce more thermal energy. This consideration has a minor effect on the total electricity production. Consequently, the most efficient system is to have $\mathrm{N}_{\mathrm{S}}$ higher than $\mathrm{N}_{\mathrm{R}}$.

It was shown that the highest total thermal energy of $10827 \mathrm{kWh} /$ heating season can be reached with low duct depth $(\mathrm{d}=38 \mathrm{~mm}[\mathrm{~d}=1.5 \mathrm{in}]$.$) and total mass flow rate (2 \mathrm{~kg} / \mathrm{s})$ for the $5 \times$ 5 arrangement. Also, high mass flow rate is necessary to produce higher amount of thermal energy. Nevertheless, on the other hand, high mass flow rate decreases the outlet air temperature from the $\mathrm{PV} / \mathrm{T}$ system. Consequently, it affects negatively on the COP of the heat pump, as it will be shown in Chapter 5.

It is important to consider the trade-off between maximizing the heat removal from the PV panels (which would be achieved by increasing air flow rate and reducing PV/T duct height) and the decline in air temperature rise and the increase in pressure drop through the collector. Also, it is important to consider the required fan power for forced ventilation air inside the duct, which was not considered here.

It was found that the amount of electrical energy produced from each PV panel depends not only on weather conditions and physical properties of the PV/T panel, but also on the panel position in a row. This is because the PV panels are cooled by the flowing air, which becomes warmer as it moves along the channel under the PV panels. Modeling a PV/T collector as a part of the roof of a building is important since the collector is a part of a detailed energy model which includes other energy system components and considers different important parameters such as radiation mode, incidence angle effect, thermal interaction with a specific zone, roof R-value and many other factors. Also, using simulation tools enables the engineers and researchers to investigate the benefits of coupling PV/T collectors with other energy systems such as a heat pump and thermal energy storage. 


\section{Chapter 4: Modeling of Transparent Backing Building Integrated Photovoltaic-Thermal Collector}

This chapter presents:

i. A detailed thermal and electrical energy generation model of transparent backing building integrated photovoltaic/thermal (TBIPV/T) system was developed. The thermal model considers the thermal resistance of the layers on both sides of the PV cell and back surface of the collector. The electrical model takes into account the effect of cell temperature and solar radiation variation on the electrical power generation. It was supposed that the PV cells operate at the maximum power point.

ii. The model considers the variation of incident angle of radiation during the days and the seasons. Therefore. The model calculates the optical properties of the cover material as a function of incident angle and collector structure.

iii. The developed model was implemented as a new Type in TRNSYS simulation program named Type 211. This new Type, like the opaque Type (Type 567), is intended to operate with detailed building model (Type 56). A detailed reference manual for Type 211 (Appendix B) was written to present the mathematical description with the solution procedure.

iv. A sensitivity analysis was done to investigate the effect of different parameters on the TBIPV/T system performance, in terms of thermal and electrical generation, and PV/T system efficiencies.

\subsection{Overview of TBIPV/T}

Transparent backing building integrated photovoltaic/thermal system (TBIPV/T), unlike the opaque (BIPV/T) system, enables solar radiation to pass through the glazing area, in between PV cells, to produce more thermal energy. Most of the research studies have been conducted for transparent backing building integrated photovoltaics (TBIPV) windows (Miyazaki et al., 2005; Chow et al., 2010a; Li et al., 2009; Fung and Yang, 2008; Kamthania and Tiwari, 2014; Kamthania et al., 2011). TBIPV systems are mainly used for passive design purposes such as illumination, aesthetic outlook, reducing the heat gain and cooling load in hot climate due to blocking of solar radiation by the opaque solar cells (Fung and Yang, 2008), utilizing natural heating during winter 
(Wong et al., 2008), and generating electricity. The typical applications of roof-mounted TBIPV systems are on the top of atriums. However, limited research has been done on roof integrated TBIPV/T systems, which simultaneously produce thermal energy and generate electricity.

The outcomes and benefits of building integrating photovoltaic/thermal glazing systems have to be examined through optical properties, thermal performance, and electricity production. Joshi et al. (2009) evaluated the thermal performance of a transparent PV/T air system. They compared the results with opaque PV/T air collector. The outcomes of the energy model were verified with experimental setup. It was found that the overall thermal efficiency of the PV/T collector with transparent backing collector was higher than glass-tedlar collector. A design of hybrid PV/T air collector was developed and installed for experimental purpose at Parco Lamro of Politecnico di Milano (Aste et al., 2008). The design was based on a mathematical model to estimate the electrical power and thermal energy production. The PV/T module was intended to be integrated on roofs or facades. The upper cover was glass sandwich with PV cells embedded. The space between the cells permits a direct solar radiation absorption by the absorber plate. A building integrating photovoltaic (BIPV) system model was created and executed in a simulation software (Guiavarch and Peuportier, 2006), considering different types of building integrated PV collectors. It was found that the overall efficiency was considerably enhanced if a PV collector was ventilated by air flowing in a channel behind the collector. The results showed that the overall efficiency of the PV panel with transparent backing PV panels was 20\% comparing with $14 \%$ efficiency for unventilated PV panels.

\subsection{Modeling and energy analysis of transparent photovoltaic/thermal collector}

A detailed model for a transparent backing BIPV/T collector was developed. This model is intended to be integrated on the roof of houses. The PV module is cooled by circulating air beneath it. Therefore, the model can only be applied to air based BIPV/T collector. Figure 4-1 shows a schematic of the collector. 


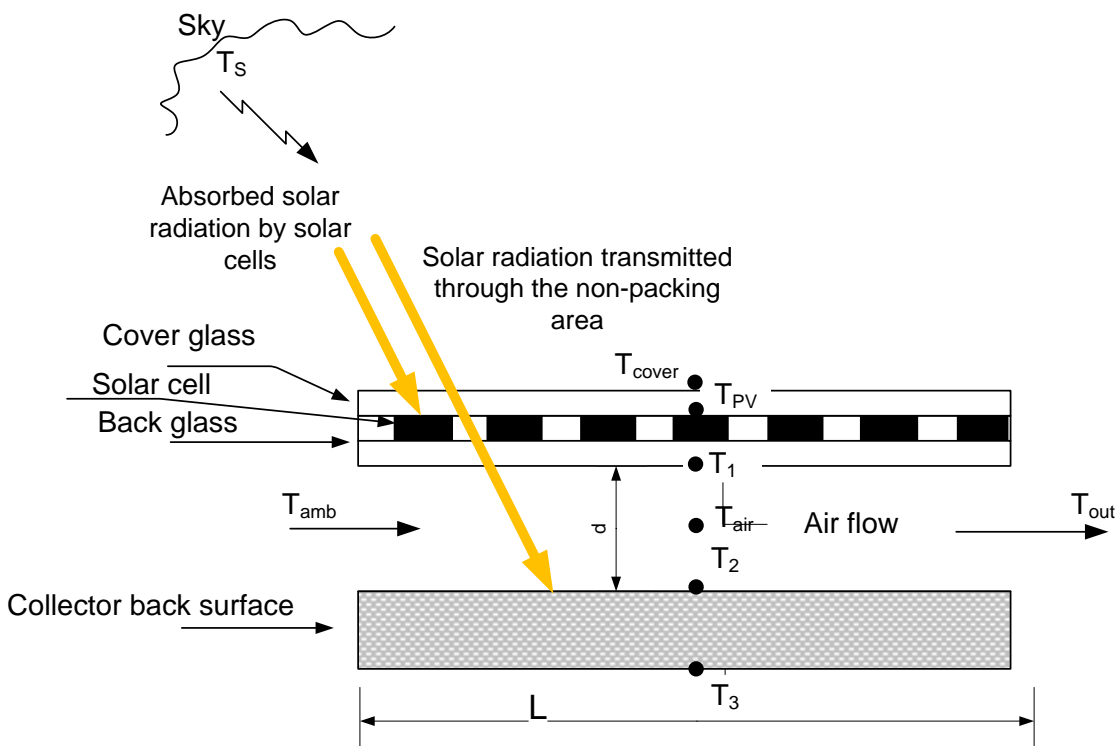

Figure 4-1: Cross section for energy balance of TBIPV/T collector

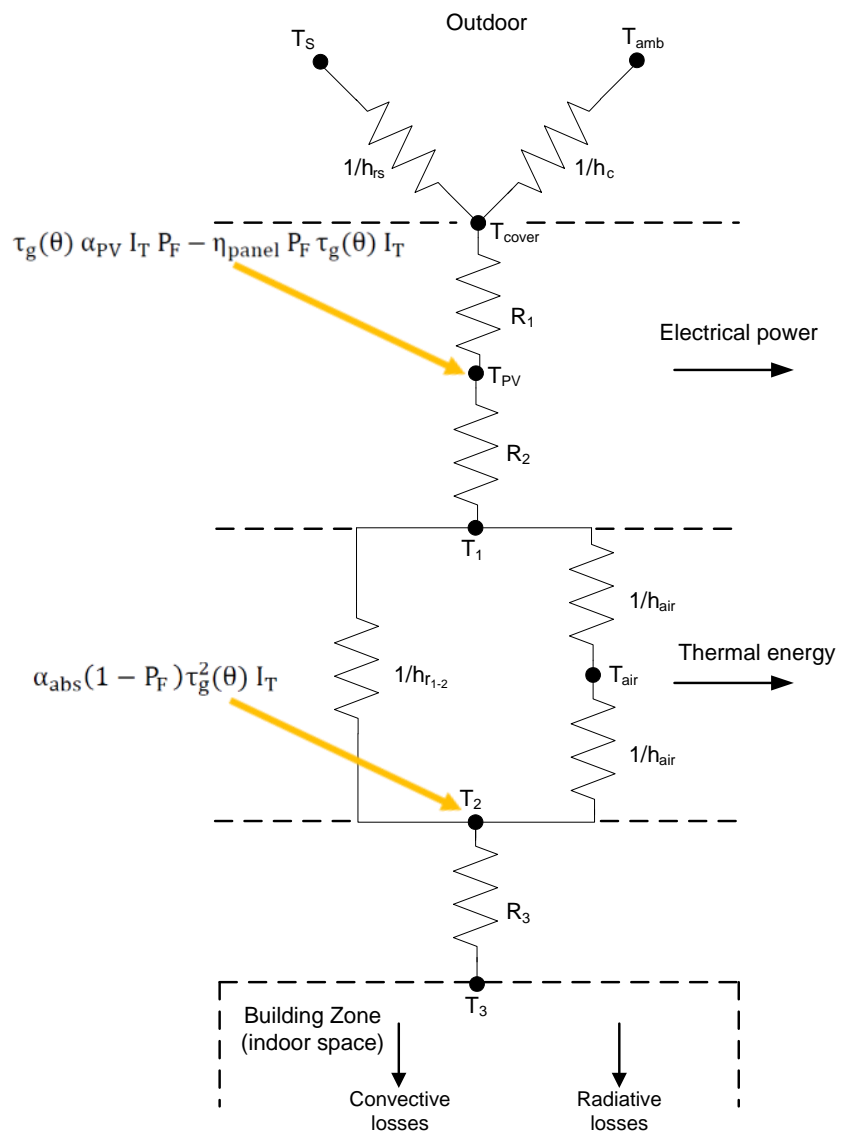

Figure 4-2: Thermal resistance for energy balance of TBIPV/T 


\subsubsection{Energy balance equations}

Based on Figures 4-1 and 4-2, the thermal energy equations of the collector parts are:

A. PV panel

- Cover glass surface: the thermal energy equation along the cover glass surface is:

$$
\frac{T_{P V}-T_{\text {cover }}}{R_{1}}=h_{c}\left(T_{\text {cover }}-T_{\text {amb }}\right)+h_{r s}\left(T_{\text {cover }}-T_{s}\right)
$$

- PV cells surface: the thermal energy equation along the PV surface (absorber surface) is:

$$
\tau_{\mathrm{g}}(\theta) \alpha_{\mathrm{PV}} \mathrm{I}_{\mathrm{T}} \mathrm{P}_{\mathrm{F}}-\eta_{\text {panel }} \mathrm{P}_{\mathrm{F}} \tau_{\mathrm{g}}(\theta) \mathrm{I}_{\mathrm{T}}=\frac{\mathrm{T}_{\mathrm{PV}}-\mathrm{T}_{\text {cover }}}{\mathrm{R}_{1}}+\frac{\mathrm{T}_{\mathrm{PV}}-\mathrm{T}_{1}}{\mathrm{R}_{2}}
$$

The left part in Equation (4-2) is the net absorbed solar radiation. The calculation of glass transmittance $\tau_{g}(\theta)$ as a function of incident angle is presented and discussed in Section 4.2.2.

- Back glass surface: the energy balance on the back glass surface (the upper air channel surface) is

$$
\frac{\mathrm{T}_{\mathrm{PV}}-\mathrm{T}_{1}}{\mathrm{R}_{2}}=\mathrm{h}_{\mathrm{air}}\left(\mathrm{T}_{1}-\mathrm{T}_{\mathrm{air}}\right)+\mathrm{h}_{\mathrm{r}_{1-2}}\left(\mathrm{~T}_{1}-\mathrm{T}_{2}\right)
$$

B. Air flowing through the channel

The thermal energy obtained from the collector is transferred by convection from upper air channel surface and lower air channel surface, represented by:

$$
\mathrm{q}=\mathrm{h}_{\text {air }}\left(\mathrm{T}_{1}-\mathrm{T}_{\text {air }}\right)+\mathrm{h}_{\text {air }}\left(\mathrm{T}_{2}-\mathrm{T}_{\text {air }}\right)
$$

C. The back insulation of the collector:

- Lower surface of air channel:

$$
\mathrm{h}_{\text {air }}\left(\mathrm{T}_{\mathrm{air}}-\mathrm{T}_{2}\right)+\mathrm{h}_{\mathrm{r}_{1-2}}\left(\mathrm{~T}_{1}-\mathrm{T}_{2}\right)+\mathrm{S}_{2}=\frac{\mathrm{T}_{2}-\mathrm{T}_{3}}{\mathrm{R}_{3}}
$$

$\mathrm{S}_{2}$ is the solar radiation received by the lower surface of air channel after transmission through the non-packing area of the PV panel, given by:

$$
\mathrm{S}_{2}=\alpha_{\mathrm{abs}}\left(1-\mathrm{P}_{\mathrm{F}}\right) \tau_{\mathrm{g}}^{2}(\theta) \mathrm{I}_{\mathrm{T}}
$$

Solving Equations (4-1) to (4-6) to find the expressions for the unknowns $T_{\text {cover }}, T_{P V}, T_{1}, T_{2}$ (detailed mathematical descriptions for solving method and the analytical expression of all 
temperature nodes are available in Appendix B). The expressions of $T_{1}$ and $T_{2}$ with Equation (44) were used to find the expression of the useful thermal energy as a function of $T_{\text {air }}$ in the form:

$$
q=a T_{\text {air }}+y
$$

The coefficients a and y in Equation (4-7) are functions of heat transfer relations and environmental conditions (the equations of the coefficients a and y are available in Appendix B). Convection and radiation heat transfer coefficients presented in Section 3.2.1 were used in the developed model of TBIPV/T collector.

As it is shown in Figure 4-3, for a section of the moving air inside the PV/T duct along the $\mathrm{x}$ direction, the energy balance is:

$$
\left(\dot{m} C T_{\text {air }}\right)_{x}-\left(\dot{m} C T_{a i r}\right)_{d x+x}+b d x q=0
$$

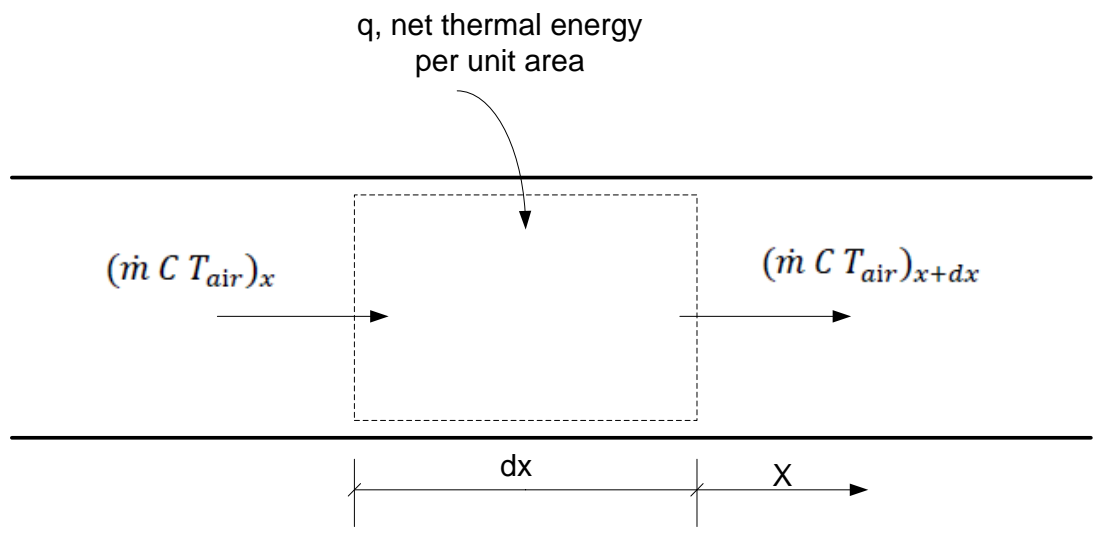

Figure 4-3: Energy balance on air element in PV/T collector (John and William, 2006)

Dividing Equation (4-8) by (dx), taking limit as (dx) approach zero, and getting:

$$
\dot{m} C \frac{d T_{a i r}}{d x}-b q=0
$$

Substituting Equation (4-7) in Equation (4-9), and integrating Equation (4-9) along flow direction (x-direction), to find local air temperature:

$$
T_{a i r}(\mathrm{x})=\left(T_{a m b}+\frac{y}{a}\right) e^{\left(\frac{b}{\dot{m} C_{p}} a \mathrm{x}\right)}-\frac{y}{a}
$$


The average air temperature can be found by integrating Eq. (4-10) for the entire PV/T collector length (L) and dividing by PV/T length. After finding the average air temperature inside the duct, the mean PV/T surface temperatures $T_{\text {cover }}, T_{P V}, T_{1}, T_{2}$ are obtained. The solution requires an iterative approach starting with initial guess values for these surface temperatures. Equation (324) was used to calculate the useful thermal energy obtained from the TBIPV/T air system. The instantaneous properties of the air stream (viscosity, density, thermal conductivity, specific heat etc.) inside the air duct are calculated from built in TRNSYS library for air properties subroutine, named "AIRPROP" using average air temperature and atmospheric pressure.

\subsubsection{Optical properties of PV/T cover}

The incident angle of solar radiation is not constant during day light hours. It changes with sun position and season. Therefore, the optical properties of the transparent cover of the PV/T collector (transmission, absorption, and reflection) are not constant at different time of the day. The optical properties are, also, functions of thickness, refractive index, and extinction coefficient of the cover material. Consequently, these optical properties affect solar heat gain and transmission of solar radiation through the non-packing area of the transparent PV/T collector. When solar radiation reaches the glass cover of a collector, part of the radiation is reflected, while part of it is absorbed, and the rest is transmitted through glass layer. The term $\left(\alpha_{\mathrm{abs}} \tau_{g}^{2}\right)$ represents the amount of the incident energy absorbed by the lower air channel surface and $\left(1-\alpha_{\mathrm{abs}} \tau_{g}^{2}\right)$ of the incident radiation is reflected back to the upper air channel surface. The multiple reflection of radiation inside the air channel continues so that the fraction of the incident energy is absorbed. The developed model considers the solar angular dependence of the optical properties along with thermal, electrical and physical properties of the TBIPV/T collector.

The transmittance of a solar collector cover as a function of the incident angle is (John and William, 2006):

$$
\tau_{\theta}=\frac{\tau_{a}(1-\rho)^{2}}{1-\left(\rho \tau_{a}\right)^{2}}
$$

The fraction of reflected solar radiation $(\rho)$ is expressed by Fresnel relation:

$$
\rho=\frac{1}{2}\left(\frac{\sin ^{2}\left(\theta_{r}-\theta\right)}{\sin ^{2}\left(\theta_{r}+\theta\right)}+\frac{\tan ^{2}\left(\theta_{r}-\theta\right)}{\tan ^{2}\left(\theta_{r}+\theta\right)}\right)
$$


Bouguer's law considers the absorption losses of incident radiation, gives the available fraction of solar radiation after absorption $\left(\tau_{a}\right)$ :

$$
\begin{aligned}
& \tau_{a}=\exp \left(\frac{-K l}{\cos \theta_{r}}\right) \\
& \theta_{r}=\sin ^{-1}\left(\frac{\sin \theta}{n_{2}}\right)
\end{aligned}
$$

The value of extinction coefficient, $K$, for glass ranges from $4 \mathrm{~m}^{-1}$ for low iron glass, white glass, to $32 \mathrm{~m}^{-1}$ for high iron glass, greenish glass (John and William, 2006). For the extinction coefficient, a value of $4 \mathrm{~m}^{-1}$ was selected to be used in Type 211 since low iron solar glass is used in solar panel (the same value was used in opaque BIPV/T collector analysis in Chapter 3). This kind of glass has the characteristics of high solar transmittance, low absorbance, and low reflectance.

In Equations (4-11) through (4-14), $\theta$ is the incident angle for the beam component of solar radiation (it is referred as $\theta_{b}$ only in Equation 4-17). The equations are also applied for sky diffused and ground reflected components, using the corresponding equivalent effective incidence angle. Brandemuehl and Beckman (1980) presented relations for effective incident angles of sky diffuse and ground reflected radiation as a function of the slope of the solar collector, $\beta$. The relations are (John and William, 2006):

$$
\begin{aligned}
& \theta_{s d}=59.68-0.1388 \beta+0.001497 \beta^{2} \\
& \theta_{g}=90-0.5788 \beta+0.002693 \beta^{2}
\end{aligned}
$$

Then, the value of the term, $\tau_{g}(\theta)$ in Equation (4-2) is obtained by:

$$
\tau_{g}(\theta)=\frac{\tau_{g}\left(\theta_{b}\right) \cdot I_{T, b}+\tau_{g}\left(\theta_{s d}\right) \cdot I_{T, S d}+\tau_{g}\left(\theta_{g}\right) \cdot I_{T, g}}{I_{T}}
$$

\subsubsection{Electrical model of the PV panel}

The electrical model used in Section 3.2 does not include the effect of changing incident solar radiation during days and seasons. However, the mathematical description for the opaque BIPV/T Type (Type 298) shows that the electrical model in TRNSYS considers both the PV panel 
temperature and solar radiation effects on the PV panel efficiency. Therefore, the same model was used in modeling the TBIPV/T collector. The instantaneous PV panel efficiency was calculated as:

$$
\eta_{\text {panel }}=\eta_{\text {ref }}\left[1-\mathrm{Eff}_{\mathrm{T}}\left(\mathrm{T}_{\mathrm{PV}}-\mathrm{T}_{\text {ref }}\right)\right]\left[1-\mathrm{Eff}_{\mathrm{I}}\left(\mathrm{I}_{\mathrm{T}}-\mathrm{I}_{\mathrm{ref}}\right)\right]
$$

$\mathrm{T}_{\text {ref }}$ and $\mathrm{I}_{\mathrm{ref}}$ are the reference temperature and reference incident solar radiation at standard test conditions. The typical values of $\mathrm{T}_{\text {ref }}$ and $\mathrm{I}_{\mathrm{ref}}$ are $25{ }^{\circ} \mathrm{C}$ and $1000 \mathrm{~W} / \mathrm{m}^{2}$, respectively (Canadian Solar, 2014).

\subsection{Type 211: Transparent building integrated PV/T system}

A computer program of the TBIPV/T model was written in FORTRAN, which includes the iteration solving method for the detailed TBIPV/T collector model. This code was used as TRNSYS's source code to create a new TRNSYS component named Type 211. In order to create a TRNSYS Type for TBIPV/T collector, all the variables in the model should be classified inside the TRNSYS Type as either "Parameters", "Inputs" or "Outputs". Time dependent inputs are the "Inputs" such as temperature, flow rate, radiation etc., while time independent inputs are the "Parameters" such as length, cover thickness, duct depth, emissivity, packing factor, etc. The outcomes of the model (thermal energy production, electricity generation, thermal efficiency, electrical efficiency etc.) are referred to "Outputs". Type 211 is intended to function with multizone building model in TRNSYS (Type 56). Tables 4-1, 4-2, and 4-3 present Input list, Parameter list, and Output list, respectively, for the new TRNSYS Type, Type 211. The source code is given in Appendix C. 
Table 4-1: Parameter list of Type 211

\begin{tabular}{|c|c|c|c|}
\hline & Name & Unit & Variable Description \\
\hline 1 & Collector length & $\mathrm{m}$ & $\begin{array}{l}\text { The length of the PV/T collector along the moving } \\
\text { air direction. }\end{array}$ \\
\hline 2 & Collector width & $\mathrm{m}$ & $\begin{array}{l}\text { The width of the collector across the direction of the } \\
\text { air flow through the channel. }\end{array}$ \\
\hline 3 & Emissivity-cover glass & - & $\begin{array}{l}\text { The emissivity of the cover surface for long-wave } \\
\text { radiation exchange with the sky. }\end{array}$ \\
\hline 4 & $\begin{array}{l}\text { Thermal conductivity of the } \\
\text { cover material }\end{array}$ & $\mathrm{W} / \mathrm{m} \cdot \mathrm{K}$ & $\begin{array}{l}\text { Thermal conductivity of the transparent glazing } \\
\text { acting as a glazing cover for the PV system. }\end{array}$ \\
\hline 5 & Cover thickness & $\mathrm{m}$ & The thickness of the transparent cover material. \\
\hline 6 & $\begin{array}{l}\text { Substrate resistance }\left(\mathrm{R}_{2} \text { in }\right. \\
\text { Figure 4-2) }\end{array}$ & $\mathrm{m}^{2} \cdot \mathrm{K} / \mathrm{W}$ & $\begin{array}{l}\text { The conductive heat transfer resistance of the material } \\
\text { located between the PV cells surface and the upper } \\
\text { flow channel surface. The resistance includes any } \\
\text { conductive resistance of the PV cells and any material } \\
\text { between the PV cells and the flow channel. }\end{array}$ \\
\hline 7 & $\begin{array}{l}\text { Emissivity- top surface of flow } \\
\text { channel }\end{array}$ & - & The emissivity of the top surface of the flow channel. \\
\hline 8 & $\begin{array}{l}\text { Emissivity- bottom surface of } \\
\text { flow channel }\end{array}$ & - & $\begin{array}{l}\text { The emissivity of the bottom surface of the flow } \\
\text { channel. }\end{array}$ \\
\hline 9 & $\begin{array}{l}\text { Resistance of the collector back } \\
\text { material }\left(\mathrm{R}_{3} \text { in Figure } 4-2\right)\end{array}$ & $\mathrm{m}^{2} \cdot \mathrm{K} / \mathrm{W}$ & $\begin{array}{l}\text { The conductive heat transfer resistance for materials } \\
\text { located between the bottom surface of the PV/T duct } \\
\text { and the backside surface of the collector. i.e. building } \\
\text { roof material }\end{array}$ \\
\hline 10 & Channel height & $\mathrm{m}$ & $\begin{array}{l}\text { The distance between the upper and lower surfaces of } \\
\text { the of the flow channel. }\end{array}$ \\
\hline 11 & Absorptance of solar cells & - & The absorptance of the PV surface for solar radiation. \\
\hline 12 & Refractive index & - & $\begin{array}{l}\text { The index of refraction of the transparent cover } \\
\text { material. }\end{array}$ \\
\hline 13 & Extinction coefficient & $1 / \mathrm{m}$ & $\begin{array}{l}\text { The extinction coefficient for the transparent glazing } \\
\text { material. }\end{array}$ \\
\hline 14 & Reference PV efficiency & - & $\begin{array}{l}\text { The efficiency of the PV panel to convert incident } \\
\text { radiation into electricity at the provided reference } \\
\text { condition. }\end{array}$ \\
\hline 15 & PV cell reference temperature & ${ }^{\circ} \mathrm{C}$ & $\begin{array}{l}\text { The reference temperature at which the reference PV } \\
\text { efficiency is provided. }\end{array}$ \\
\hline 16 & PV cell reference radiation & $\mathrm{W} / \mathrm{m}^{2}$ & $\begin{array}{l}\text { The reference total incident solar radiation at which } \\
\text { the reference PV efficiency is provided. }\end{array}$ \\
\hline 17 & $\begin{array}{l}\text { Efficiency modifier - } \\
\text { Temperature }\end{array}$ & $1 /{ }^{\circ} \mathrm{C}$ & $\begin{array}{l}\text { The multiplier to correct the rated PV efficiency as a } \\
\text { function of PV temperature. }\end{array}$ \\
\hline 18 & $\begin{array}{l}\text { Efficiency modifier - Incident } \\
\text { solar radiation }\end{array}$ & $\mathrm{m}^{2} / \mathrm{W}$ & $\begin{array}{l}\text { The multiplier to correct the rated PV efficiency as a } \\
\text { function of incident solar radiation. }\end{array}$ \\
\hline 19 & Packing factor & - & The ratio of solar cells area to the PV module area. \\
\hline 20 & $\begin{array}{l}\text { Absorbance of lower air-channel } \\
\text { surface }\end{array}$ & - & $\begin{array}{l}\text { The Absorbance of lower air-channel surface for solar } \\
\text { radiation received through the non-packing area. }\end{array}$ \\
\hline 21 & LOC & - & $\begin{array}{l}\text { The location of the panel in series (in a row), } \mathrm{LOC}=1 \\
\text { the first panel, } \mathrm{LOC}=2 \text { for the second panel....etc. }\end{array}$ \\
\hline
\end{tabular}


Table 4-2: Input list of Type 211

\begin{tabular}{|c|l|l|l|}
\hline & Name & Unit & Variable Description \\
\hline 1 & Inlet temperature & $\mathrm{kg} / \mathrm{s}$ & $\begin{array}{l}\text { The temperature of air entering the flow channel of the } \\
\text { collector. }\end{array}$ \\
\hline 2 & Inlet flow rate & $\begin{array}{l}\text { Mass flow rate of air entering the flow channel of the } \\
\text { collector. }\end{array}$ \\
\hline 3 & Ambient temperature & $\begin{array}{l}\text { The temperature of the environment in which the } \\
\text { collector is located. }\end{array}$ \\
\hline 4 & Sky temperature & ${ }^{\circ} \mathrm{C}$ & $\begin{array}{l}\text { The temperature of the sky for calculating long-wave } \\
\text { radiation losses from the collector surface. }\end{array}$ \\
\hline 5 & Back surface temperature & $\begin{array}{l}\text { The temperature of the back surface of the collector. } \\
\text { This value is calculated by the detailed zone model } \\
\text { (Type 56). }\end{array}$ \\
\hline 6 & $\begin{array}{l}\text { Total Incident solar radiation } \\
\text { on tilted surface }\end{array}$ & $\mathrm{W} / \mathrm{m}^{2}$ & $\begin{array}{l}\text { The total (beam + diffuse) radiation incident upon the } \\
\text { specified surface. }\end{array}$ \\
\hline 7 & $\begin{array}{l}\text { Beam radiation on tilted } \\
\text { surface }\end{array}$ & $\mathrm{W} / \mathrm{m}^{2}$ & $\begin{array}{l}\text { The beam radiation incident upon the specified } \\
\text { surface. }\end{array}$ \\
\hline 8 & $\begin{array}{l}\text { Sky diffuse radiation on tilted } \\
\text { surface }\end{array}$ & $\mathrm{W} / \mathrm{m}^{2}$ & $\begin{array}{l}\text { The incident sky diffuse radiation on the specified } \\
\text { surface. }\end{array}$ \\
\hline 9 & $\begin{array}{l}\text { Ground reflected diffuse } \\
\text { radiation on tilted surface }\end{array}$ & $\mathrm{W} / \mathrm{m}^{2}$ & $\begin{array}{l}\text { The incident ground reflected diffuse radiation on the } \\
\text { specified surface. }\end{array}$ \\
\hline 10 & Incidence angle & $\mathrm{deg}$ & $\begin{array}{l}\text { The angle of incident between incident beam radiation } \\
\text { and the sloped collector surface. }\end{array}$ \\
\hline 11 & Collector slope & $\mathrm{deg}$ & The slope of the collector surface \\
\hline 12 & Top heat loss coefficient & $\mathrm{W} / \mathrm{m}^{2} \cdot \mathrm{K}$ & $\begin{array}{l}\text { The convection heat transfer coefficient from the } \\
\text { cover to the ambient (radiative losses are not included) }\end{array}$ \\
\hline 13 & $\begin{array}{l}\text { Atmospheric pressure } \\
\text { atm }\end{array}$ & $\begin{array}{l}\text { The absolute pressure of the air flowing through the } \\
\text { collector }\end{array}$ \\
\hline
\end{tabular}

Table 4-3: Output list of Type 211

\begin{tabular}{|c|l|l|l|}
\hline & Name & Unit & Variable Description \\
\hline 1 & Outlet air temperature & ${ }^{\circ} \mathrm{C}$ & The temperature of the air exiting the collector \\
\hline 2 & Outlet air flow rate & $\mathrm{kg} / \mathrm{hr}$ & The flow rate of the air exiting the collector \\
\hline 3 & Useful thermal energy gain & $\mathrm{kJ} / \mathrm{hr}$ & $\begin{array}{l}\text { The net rate at which thermal energy is transferred to } \\
\text { the air flowing through the collector }\end{array}$ \\
\hline 4 & Thermal efficiency & - & $\begin{array}{l}\text { The efficiency of the collector in converting incident } \\
\text { solar radiation to thermal energy }\end{array}$ \\
\hline 5 & Electrical power & $\mathrm{kJ} / \mathrm{hr}$ & $\begin{array}{l}\text { The rate at which the PV cells are producing electrical } \\
\text { power }\end{array}$ \\
\hline 6 & Electrical efficiency & - & $\begin{array}{l}\text { The efficiency of the PV cells in converting incident } \\
\text { solar radiation to electrical energy }\end{array}$ \\
\hline 7 & Cover temperature & ${ }^{\circ} \mathrm{C}$ & The mean surface temperature of the cover \\
\hline 8 & PV cell temperature & ${ }^{\circ} \mathrm{C}$ & The temperate of the absorbing PV surface \\
\hline 9 & $\begin{array}{l}\text { Upper air channel surface } \\
\text { temperature }\end{array}$ & ${ }^{\circ} \mathrm{C}$ & The mean temperature of the upper air channel surface \\
\hline 10 & Mean fluid temperature & ${ }^{\circ} \mathrm{C}$ & The mean temperature of the air in the collector \\
\hline
\end{tabular}




\begin{tabular}{|c|c|c|c|}
\hline 11 & $\begin{array}{l}\text { Lower air channel surface } \\
\text { temperature }\end{array}$ & ${ }^{\circ} \mathrm{C}$ & The mean temperature of the lower air channel surface \\
\hline 12 & Back surface temperature & ${ }^{\circ} \mathrm{C}$ & $\begin{array}{l}\text { The mean temperature of the back surface of the } \\
\text { collector (zone air/collector back interface) }\end{array}$ \\
\hline 13 & Convective top losses & $\mathrm{kJ} / \mathrm{hr}$ & $\begin{array}{l}\text { The rate at which energy is lost to the environment } \\
\text { through convection from the cover surface to the } \\
\text { ambient air }\end{array}$ \\
\hline 14 & Radiative top losses & $\mathrm{kJ} / \mathrm{hr}$ & $\begin{array}{l}\text { The rate at which energy is lost to the environment } \\
\text { through radiation exchange from the cover surface to } \\
\text { the sky }\end{array}$ \\
\hline 15 & Back losses & $\mathrm{kJ} / \mathrm{hr}$ & $\begin{array}{l}\text { The rate at which the energy is lost from the back } \\
\text { surface of the collector to the zone }\end{array}$ \\
\hline 16 & $\begin{array}{l}\text { Absorbed solar radiation be } \\
\text { solar cells }\end{array}$ & $\mathrm{kJ} / \mathrm{hr}$ & $\begin{array}{l}\text { The absorbed solar radiation by the PV cells after } \\
\text { passing the cover (not including the radiation that is } \\
\text { converted to electrical energy }\end{array}$ \\
\hline 17 & Transmittance of cover glass & - & The transmittance of cover glass \\
\hline 18 & $\begin{array}{l}\text { Received solar radiation by } \\
\text { lower air channel surface }\end{array}$ & $\mathrm{kJ} / \mathrm{hr}$ & $\begin{array}{l}\text { Solar radiation received by the lower air channel } \\
\text { surface after passing the non-packing are of the PV } \\
\text { panel }\end{array}$ \\
\hline
\end{tabular}

\subsection{Sensitivity analysis of different parameters}

The effects of different parameters of the TBIPV/T system such as packing factor (the ratio of PV cells area in the panel to the actual area of the panel), collector tilt angle and optical properties on the productivity of the collector in term of thermal and electrical generation were analyzed. In addition, the effect of these parameters on PV panel efficiency, thermal efficiency and the combined efficiency was examined.

The TRNSYS house model presented in Section 3.5 was used to conduct the sensitivity analysis for TBIPV/T collector; Type 298 was replaced by Type 211 with efficiency of $16 \%$ under standard test condition. The analysis was done for air mass flow rate of $0.2 \mathrm{~kg} / \mathrm{s}$. Fig. 4-4(a) shows the effect of packing factor on hourly production of the thermal energy from one PV/T panel in a typical day in winter (Jan. 21). It was found that decreasing the packing factor, which means more glass area, resulted in more useful collected thermal energy. Part of the incident solar radiation passed through the transparent part of the collector and hit the lower surface of the air channel. The TBIPV/T collector was defined to have an absorber plate on the lower surface of the air channel in order to allow the transmitted radiation through the non-packing area to be absorbed. In this case, a certain amount of thermal energy was available on this surface depending on its absorptivity $\left(\alpha_{a b s}\right)$, which was defined as a Parameter in Type 211 (Parameter 20 in Table 4-1); its value was assumed to be 0.8 for this analysis. Then, the absorbed heat was transferred to the 
flowing air by convection. However, a larger packing factor produces more electricity as shown in Fig. 4-4(b). As the packing factor reduced from 0.9 to 0.5 , the thermal energy production/day increases by $25 \%$ while electricity generation/day declined by $42 \%$ due to less solar PV cells area.

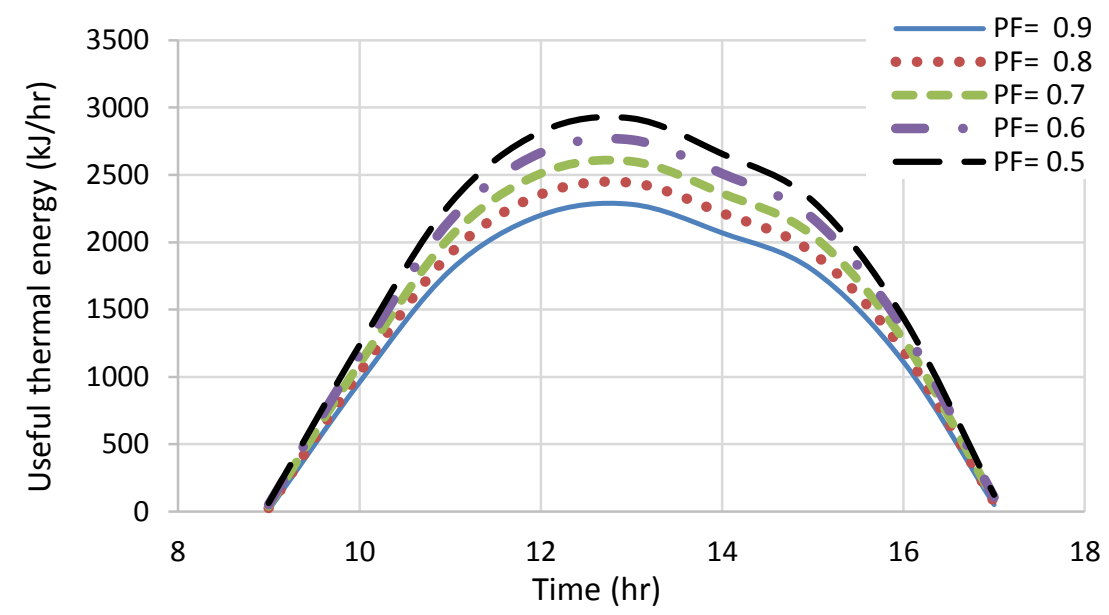

(a)

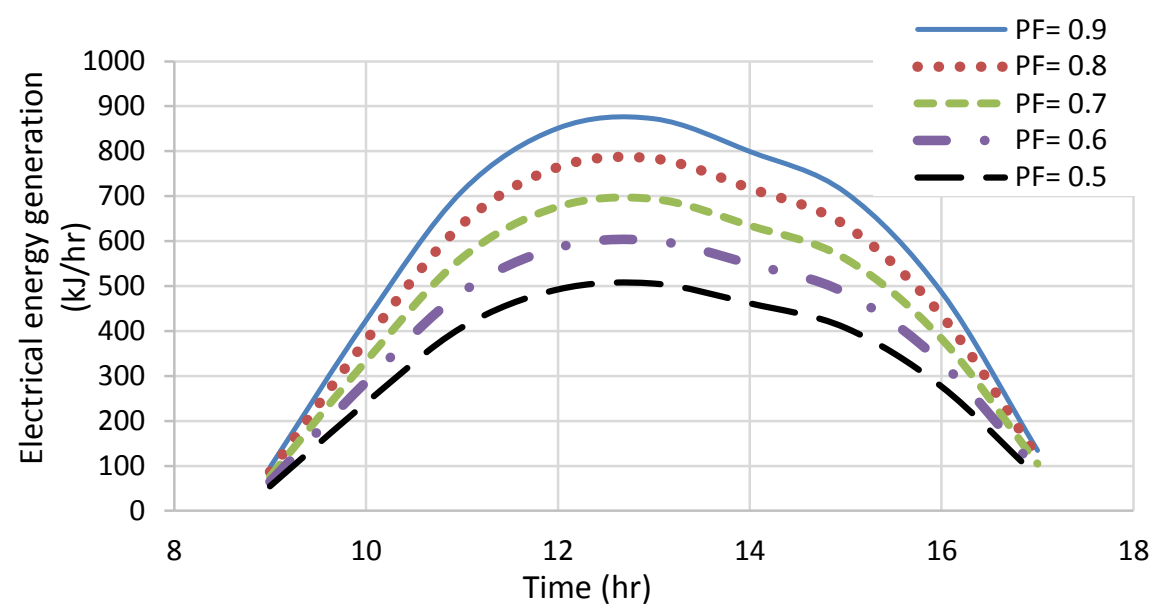

(b)

Figure 4-4: The effect of packing factor on (a) useful thermal energy (b) electricity generation from TBIPV/T collector in a typical winter day (Jan. 21)

Figure 4-5 shows that the daily average of thermal efficiencies were $32.8 \%$ and $41.5 \%$ (ignoring the early morning and late afternoon low thermal efficiencies values due to low intensity of solar radiation as shown in Figure 4-7) for packing factor of 0.9 and 0.5, respectively. This is because the outlet air temperature for $\mathrm{PV} / \mathrm{T}$ system with $\mathrm{PF}=0.5$ is higher due to more solar radiation falls on non-packing area and transmits through the glass. Consequently, PV cells 
temperatures are reduced as shown in Fig. 4-6. It is observed that decreasing the packing factor from 0.9 to 0.5 decreased the maximum PV panel temperature from $23.1{ }^{\circ} \mathrm{C}$ to $14.5{ }^{\circ} \mathrm{C}$ around noon which, in turn, raised the PV panel electrical efficiency from $16 \%$ to $17 \%$. Since both thermal and electrical efficiency of the collector are improved with lower packing factor, the overall efficiency is also enhanced.

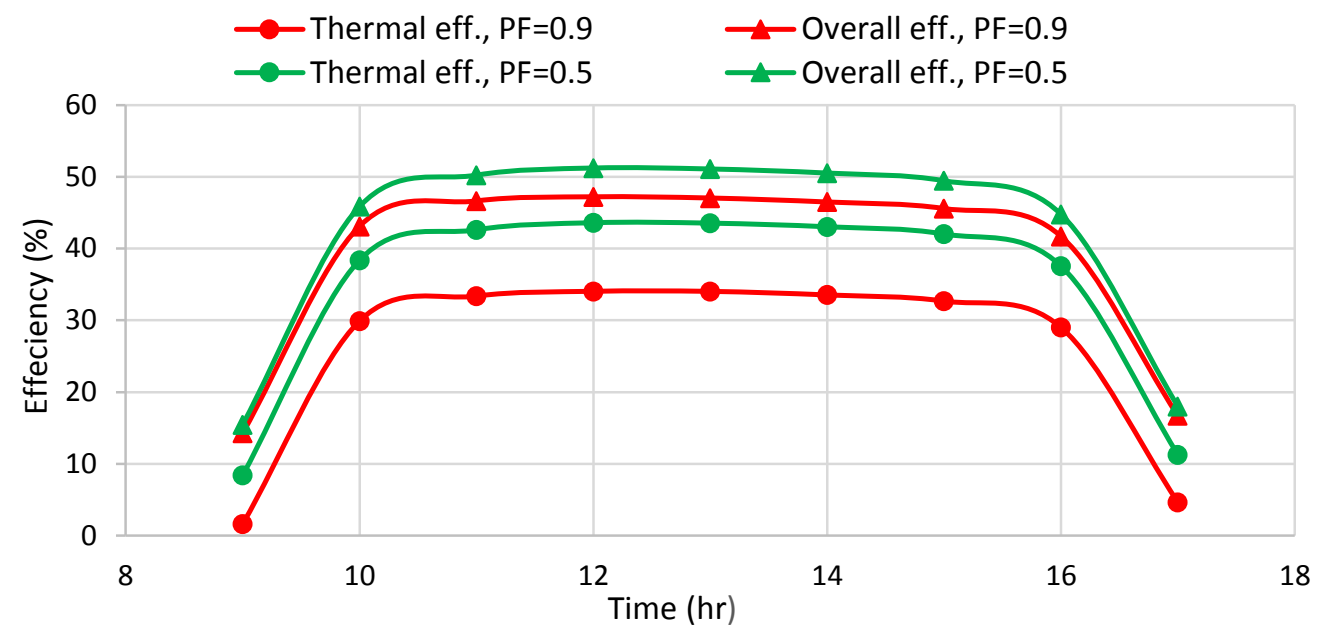

Figure 4-5: Hourly variation of the TBIPV/T collector thermal efficiency and overall efficiency with different packing factor in a typical winter day (Jan. 21)

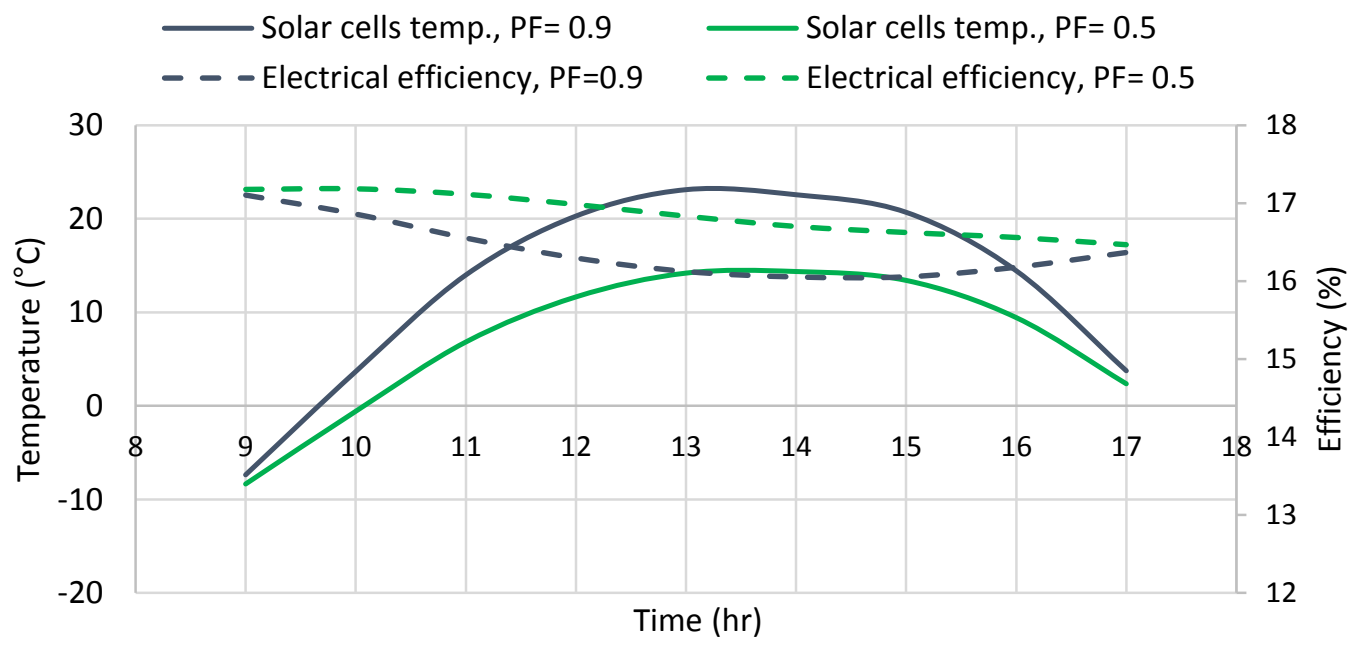

Figure 4-6: Hourly variation of the PV cell temperature and efficiency

Figures 4-8 and 4-9 show hourly productions of the electrical power and thermal energy from one transparent PV/T panel on a typical day in both summer and winter. The hourly amounts 
of the produced electrical and thermal energy are directly proportional to the availability of solar radiation. Since the solar radiation intensity in a summer day is greater than in a winter day (see Figure 4-7), the instantaneous values of the useful thermal energy in summer are higher than that of a winter day as shown in Figure 4-8. Consequently, the total yield of the thermal energy for the whole day were $15,942 \mathrm{~kJ}$ and $20,228 \mathrm{~kJ}$ in summer for packing factors of 0.9 and 0.5 respectively, while the values of the useful thermal energy for winter were $12,270 \mathrm{~kJ}$ and $15,844 \mathrm{~kJ}$ for packing factor of 0.9 and 0.5 respectively.

However, it is shown from Figure 4-9 the instantaneous values of electrical power production around noon in a summer day were less compared to the corresponding values of the electrical power in a winter day for the same packing factor. For example, at 1:00 pm and for a packing factor of 0.9 , the instant values of electrical power production were $872 \mathrm{~kJ}$ in winter day and $809 \mathrm{~kJ}$ in summer day. This is because the cell temperature during summer is higher than during winter. It was found that the average values of the PV panel temperatures around noon, on a summer day, were $35^{\circ} \mathrm{C}$ and $44^{\circ} \mathrm{C}$ for 0.5 and 0.9 packing factor, respectively; while the average cell temperatures during a winter day were $14^{\circ} \mathrm{C}$ and $22^{\circ} \mathrm{C}$ for 0.5 and 0.9 packing factor, respectively. Nevertheless, the total daily amount of the electrical power in summer $(5,855 \mathrm{~kJ}$ for $\mathrm{PF}=0.9$ and $3,374 \mathrm{~kJ}$ for $\mathrm{PF}=0.5)$ was more than the electrical production in winter $(5,083 \mathrm{~kJ}$ for $\mathrm{PF}=0.9$ and 2,922 $\mathrm{kJ}$ for $\mathrm{PF}=0.5$ ) due to longer day light hours during the summer season.

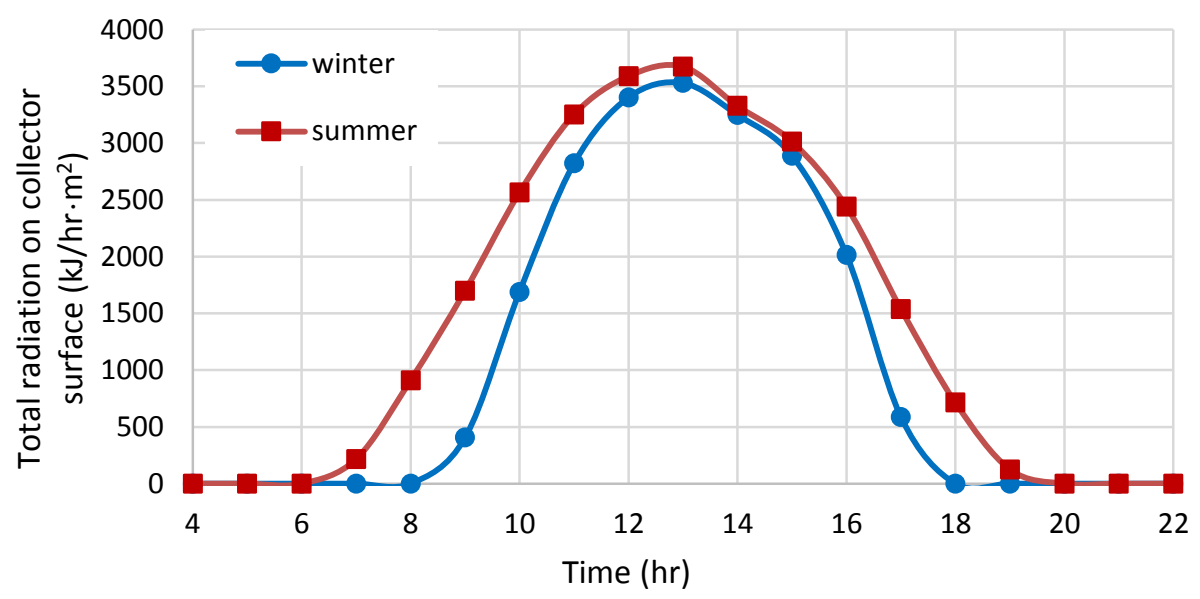

Figure 4-7: Hourly variation of total incident solar radiation on a tilted surface in Toronto during a typical day in winter and summer 


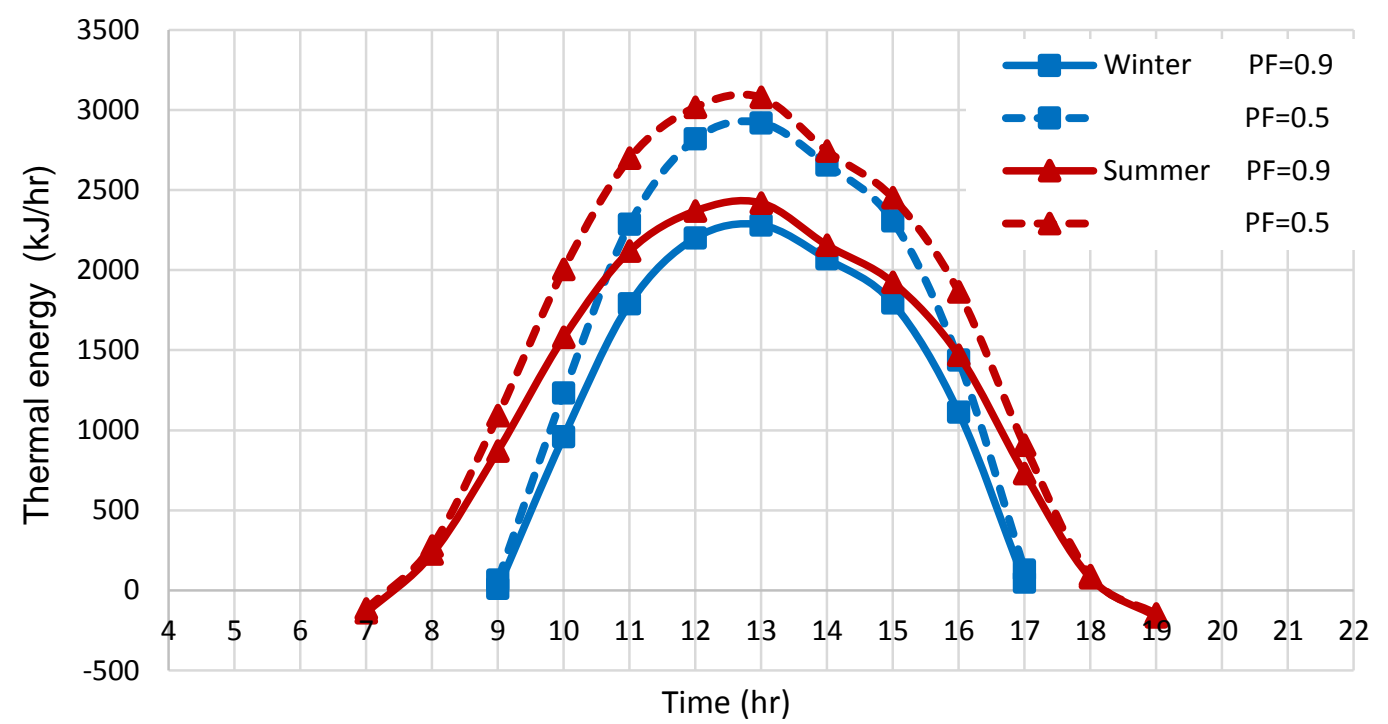

Figure 4-8: Hourly variation of useful thermal energy obtained from TBIPV/T collector with different packing factors in a typical day in winter (Jan. 21) and a typical day in summer (Aug. 16)

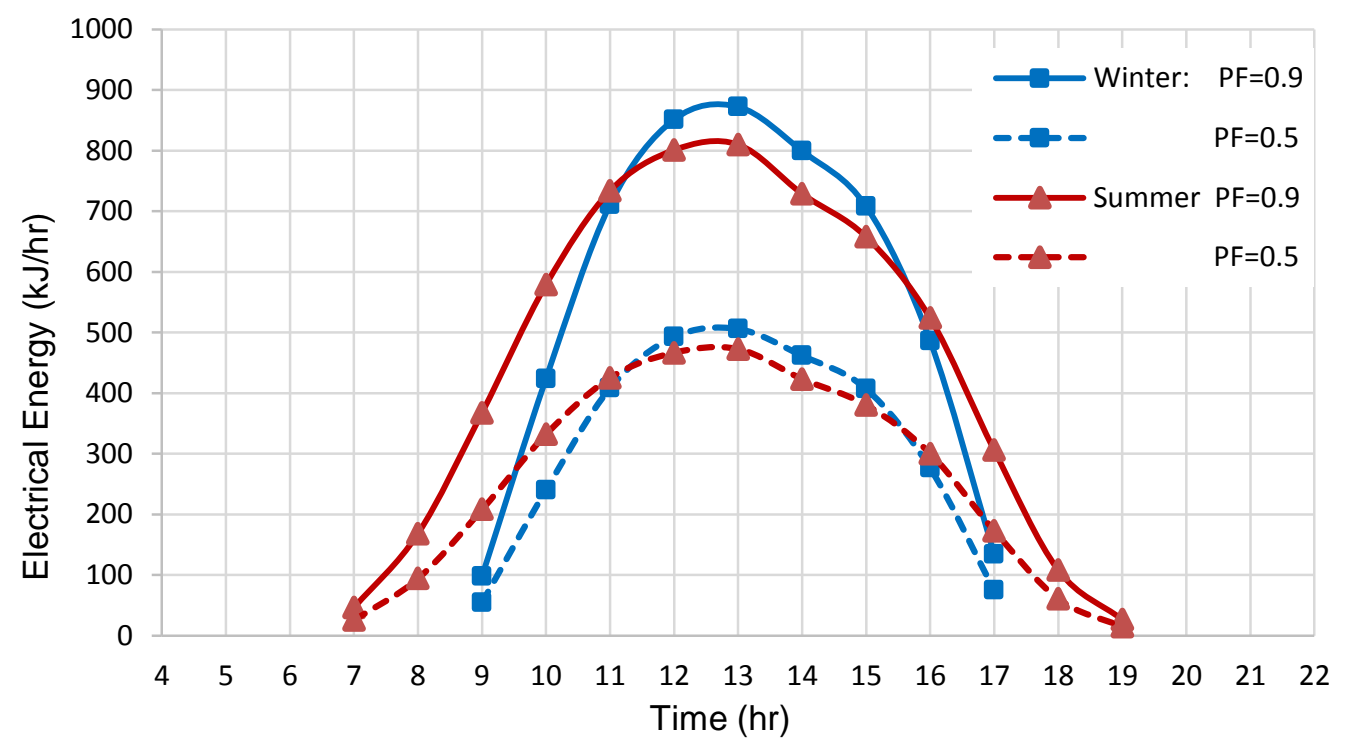

Figure 4-9: Hourly variation of electrical energy obtained from TBIPV/T collector with different packing factors in a typical day in winter (Jan. 21) and a typical day in summer (Aug. 16)

Unlike many previously developed models for TBIPV/T collectors that use a constant transmittance value (Kamthania et al., 2011; Joshi et al., 2009 and Tiwari et al., 2011), the effect of radiation incident angle on the transmittance of the transparent part of the PV/T was considered in the developed model. Figure 4-10 shows the effect of the hourly varying of radiation incident angle (the angle between the radiation on a surface and normal to that surface) on the transmissivity 
of the glass with different collector slope angles. The analysis was done for a typical day in summer and in winter. The incident angle value depends on the collector slope, location, and time (Soto et al., 2006). In this analysis, the collector is facing the equator (the south for northern hemisphere). It is clear from Figures 4-10(a) and 4-10(b) that as incident angle increases, which usually happens early in the morning and late in the afternoon, the transmittance decreases because a higher amount of radiation is reflected from the cover. Regarding the effect of collector slope and season, for a large collector slope $\left(60^{\circ}\right)$, the transmittance during the winter day is higher than the transmittance if the collector slope is $30^{\circ}$. This is due to low values of solar altitude in winter resulting in a low incident angle for incident solar radiation on a tilted surface. In contrast with a summer day, Figure 4-10(b) shows that a collector slope of $30^{\circ}$ gives a high value of transmittance. Therefore, the higher collector tilt angle in winter, or the lower collector tilt angle in summer, the more thermal energy is produced from the collector, as shown in Figure 4-11.

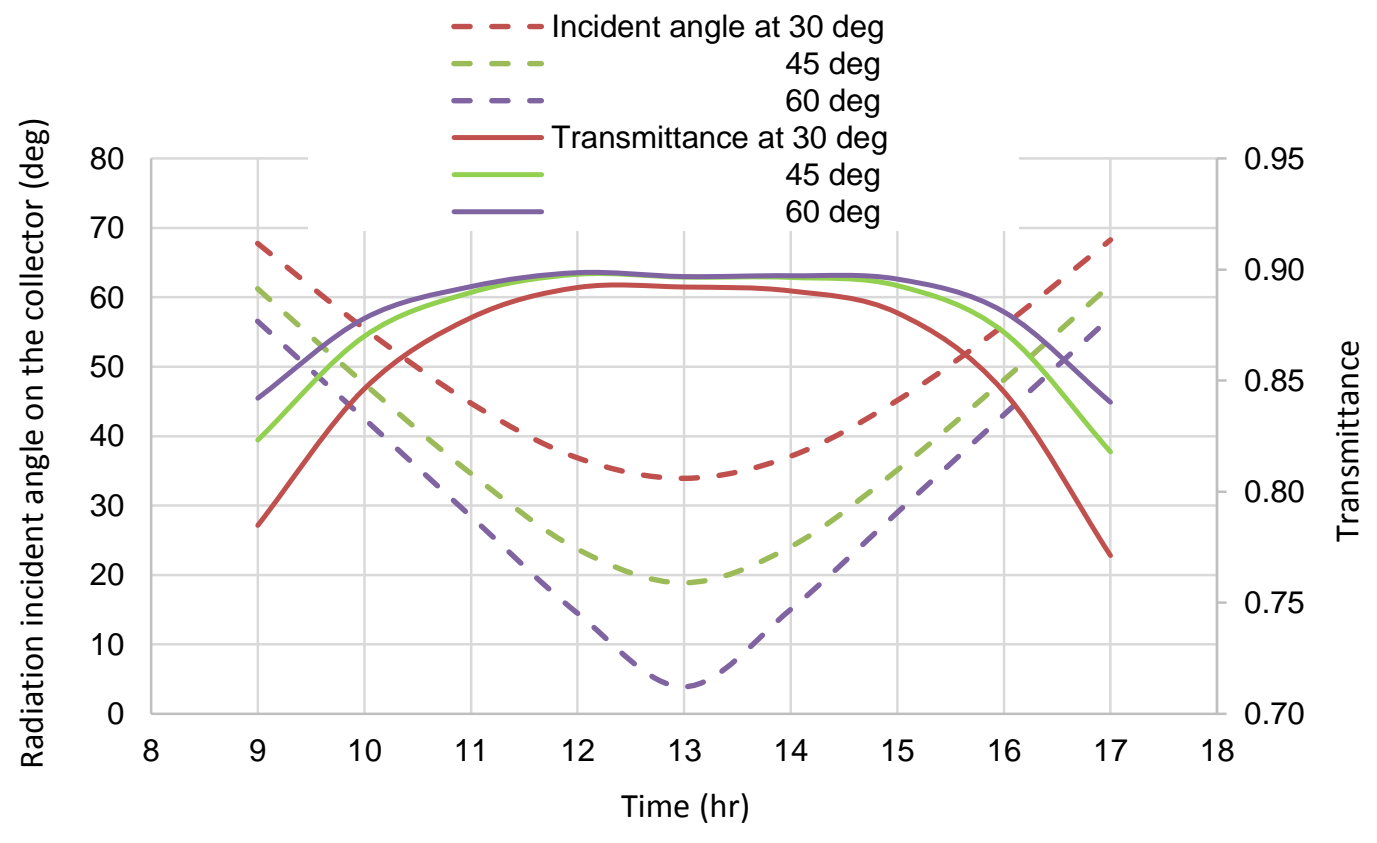

(a) Winter 


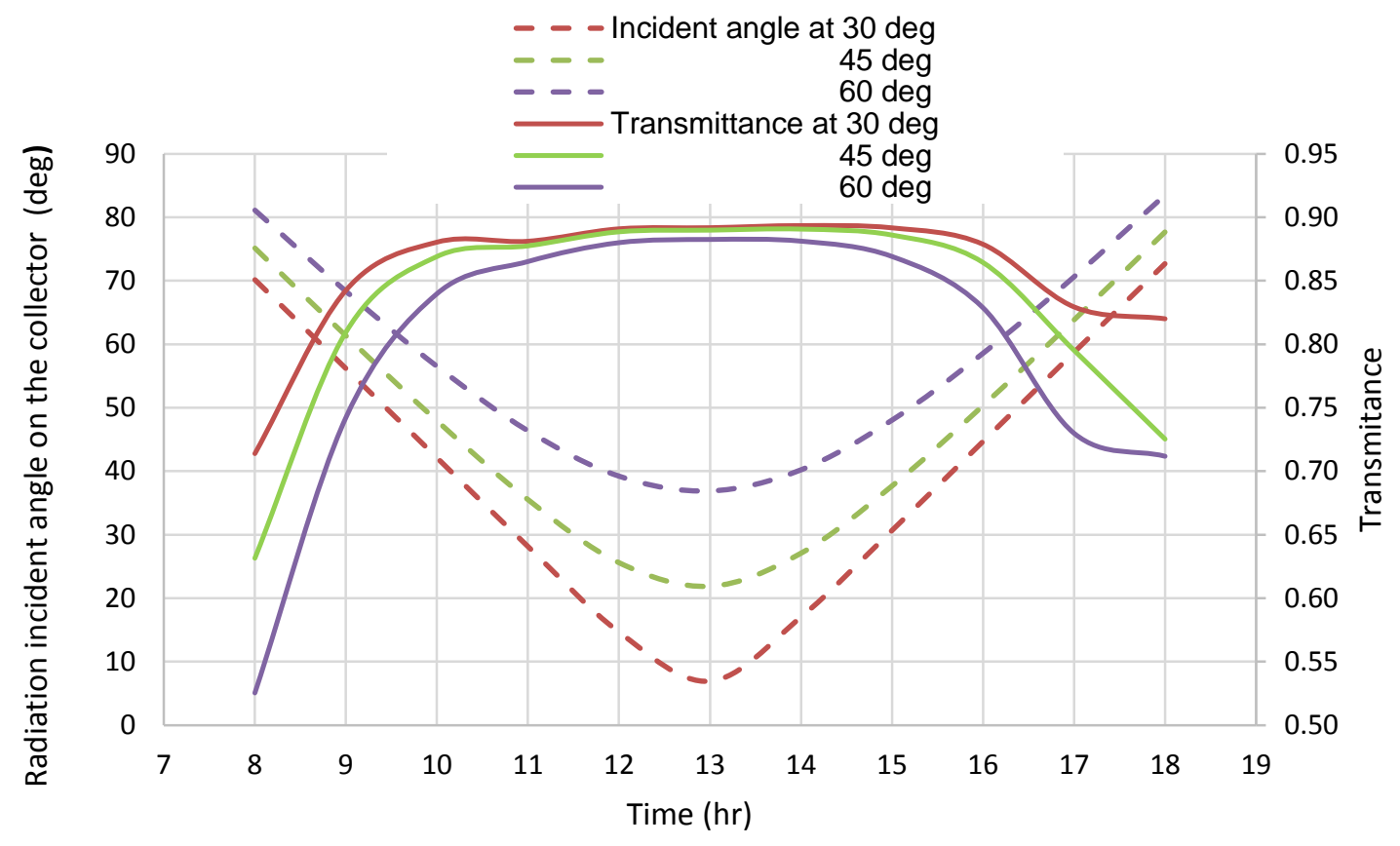

(b) summer

Figure 4-10: Hourly variation of glass transmittance and radiation incident angle for different TBIPV/T collector slopes in (a) winter and (b) summer

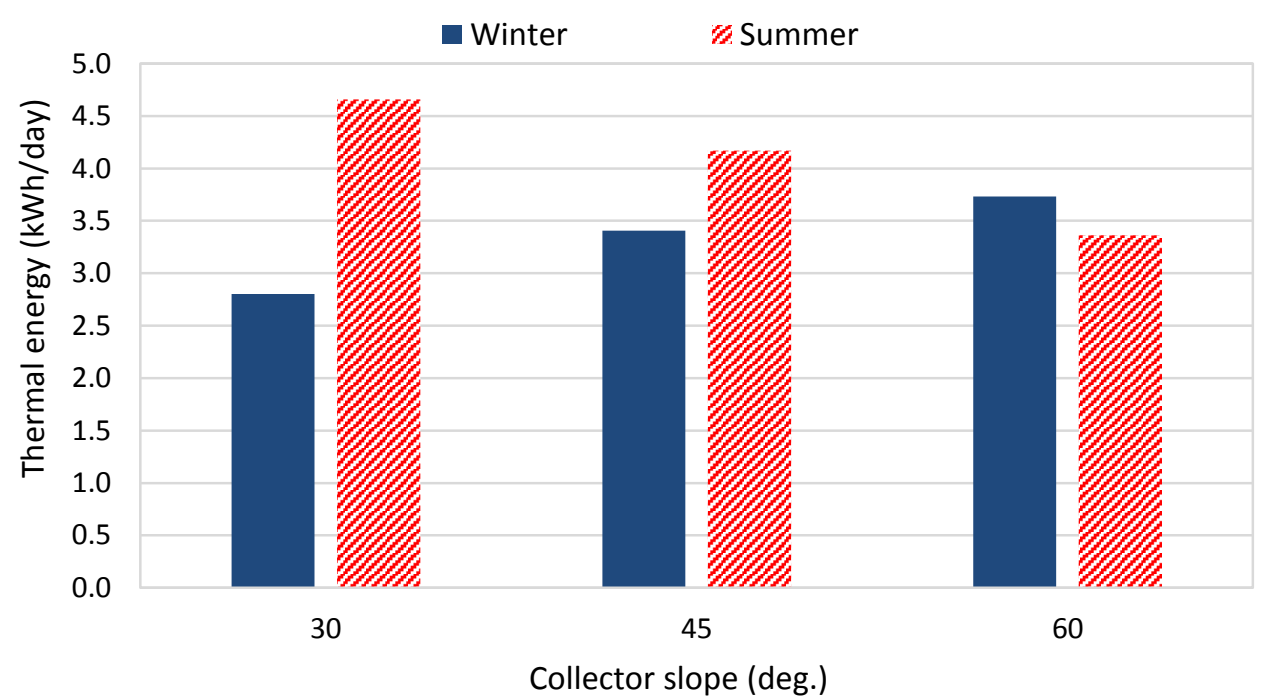

Figure 4-11: Effect of collector slope on useful thermal energy obtained from TBIPV/T system for winter and summer typical days 


\subsection{Summary and conclusion}

A transparent backing BIPV/T model was developed and used to create a new Type, called Type 211, in TRSNSY. Currently, a transparent BIPV/T model does not exist in TRNSYS software. This new Type will help users in large-scale applications of roof integrated transparent building integrated photovoltaic-thermal collector for different locations. A full description manual was presented to help users to understand the analytical expressions used in developing the model and the iterative solving procedure. All types of variables (Parameters, Input, and Output) used in the model were also presented.

In a transparent BIPV/T collector, the heat is transferred to air flowing inside the duct by not only convection and radiation from upper and lower surfaces of flow channel, but also the transmitted solar radiation through the non-packing area. The bottom surface of the air channel acts as an absorber plate. In this case, the transmitted solar radiation is absorbed by this surface and then the energy is released by convection to the flowing air. Therefore, low packing factor increases the useful thermal gain from a transparent collector, but decreases the amount of electrical power production. However, the overall TBIPV/T efficiency is higher for lower packing factor. The amount of solar radiation transmitted through the glazing part is affected by the angle of the collector and day light time during the day. For summer season, it is better to have a low collector tilt angle, while in winter it is preferred to have the panel to a steeper angle. The current analysis delivers beneficial understanding of thermal and electrical performance of a transparent BIPV/T collector. 


\section{Chapter 5: Modeling, Simulation and Feasibility Analysis of Residential BIPV/T+ASHP System in Cold Climate - Canada}

This chapter presents:

i. TRNSYS simulation software was used to model a combined building integrated photovoltaic-thermal (BIPV/T) Collector and an air source heat pump (ASHP) in residential house.

ii. The feasibility analysis for coupling BIPV/T with air source heat pump was done based on the verified model of the Archetype Sustainable House (ASH) at Kortright Centre. A brief description for ASH is mentioned in (Section 5.1) to give an idea about the house and its mechanical system.

iii. Estimate the potential benefit and improvement in the heat pump performance and potential reduction in electricity demand of the ASHP by the direct coupling of BIPV/T+ASHP without the use of diurnal thermal storage

iv. The saving in the electricity cost and energy, GHG emission reduction by combining a PV/T array and an air source heat pump, and the credit of selling the electricity produced by the PV panels to a local grid in Toronto.

\subsection{The Archetype Sustainable House description}

The Toronto and Region Conservation Authority (TRCA, 2009) together with the Building Industry and Land Development (BILD) Association have implemented the "Sustainable Archetype House" project at The Living City Campus at the Kortright Centre in Vaughan, Ontario, Canada. This Archetype Sustainable House was designed to demonstrate viable, sustainable housing technologies in the near and medium terms through research, demonstration, education, training, market transformation and partnership programs. The Archetype Sustainable House (ASH) is a semi-detached twin-house, House-A and House-B. The analyses in this chapter are related to House A (the house on the left in Figure 5-1), a 3-storey south facing house, which has a total (excluding basement) floor area of $261 \mathrm{~m}^{2}$. All windows are double glazed with a U-value of $2.19 \mathrm{~W} / \mathrm{m}^{2} \mathrm{~K}$ with a total window area of $37.68 \mathrm{~m}^{2}$. Roxul fibre batt and 3" Styrofoam were used in the above grade walls with an overall resistance of RSI-5.31 (R-30), and Durisol blocks of RSI3.54 (R-20) was used for the basement wall/foundation. The roof was constructed with Structurally 
Insulated Panel (SIP) with RSI-7 (R-40) (Safa et al., 2011a; Barua et al., 2010). Therefore, the back material of the BIPV/T system in the model in Section 5.2 is the roof material of House A.

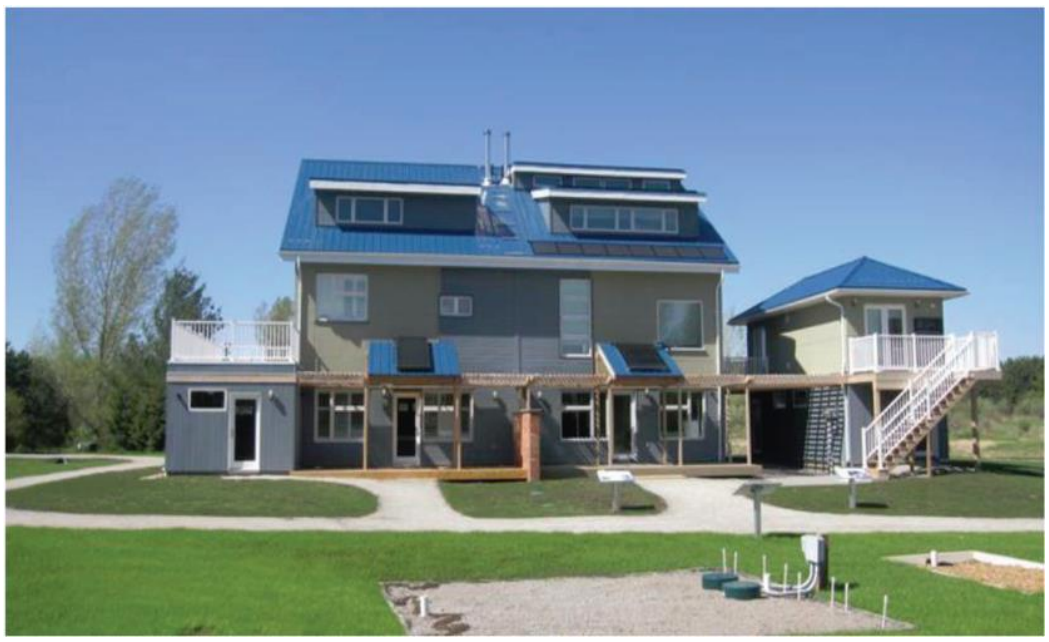

Figure 5-1: South side of twin houses (Safa et al., 2015a)

\subsubsection{House-A: The mechanical system and the TRNSYS model}

In the mechanical system in House A, a variable capacity two-stage air-to-air heat pump was used for heating and cooling the house. The heating and cooling was delivered through a direct expansion air-handling unit (AHU), which supplied conditioned air to all floors of the house. The mechanical system included a small boiler, which uses a natural gas. The boiler is used to provide hot water to the heating coil of the air-handling unit when the heat pump is unable to meet the heating demand in very cold days. The backup heating system is part of the overall commercial ASHP package proposed to be used in cold climate like Canada. However, the natural gas boiler was not running during the research time (Zhang et al., 2010).

In the mechanical ventilation system, a heat recovery ventilator (HRV) was used to recover waste heat from the exhaust air from the kitchen and washrooms/bathrooms. The fresh air was preheated by the waste heat in HRV in the winter season. More than 300 sensors of different types were installed and calibrated to record data for all mechanical system parts. More details related to the monitoring system and the mechanical system are presented elsewhere (Barua, 2010; Safa et al., 2015a).

A TRNSYS model of House-A was developed and validated with the data collected from monitoring the ASHP (Safa et al., 2011b). An air source heat pump TRNSYS type (Type 665) was 
integrated with the house model. The collected data were used to develop the performance curve showing the daily cooling and heating production from the ASHP as a function of the average ambient temperature. The heating and cooling demands of House A were obtained from the simulation of TRNSYS house model. The results were verified based on the collected data.

The validated model of House A was run for a year, using Toronto weather file, to estimate the yearly heating, cooling and peak demand. The heating season was supposed to begin October $1^{\text {st }}(6576 \mathrm{~h})$ to May $22^{\text {nd }}(3408 \mathrm{~h})$, the value of the heating set-point temperature was $21^{\circ} \mathrm{C}$. The cooling season was supposed to start on May $23^{\text {rd }}(3409 \mathrm{~h})$ and end on September $30^{\text {th }}(6575 \mathrm{~h})$ with an indoor set point temperature of $23^{\circ} \mathrm{C}$. It was found that the highest cooling and heating loads were $5.08 \mathrm{~kW}$ and $6.76 \mathrm{~kW}$, respectively, corresponding to maximum and minimum hourly outdoor temperatures of $33.9^{\circ} \mathrm{C}$ and $-22.11^{\circ} \mathrm{C}$, respectively. The total heating demand for House A at the end of the heating season was $17,870 \mathrm{kWh}$. The seasonal electricity consumption by the heat pump was $6522 \mathrm{kWh}$ resulting in seasonal heating COP of 2.74 for the heating season of Toronto.

\subsection{Model development and methodology}

The TRNSYS model of the house was modified by integrating a PV/T system on the southoriented roof. Then, the PV/T array was linked to the heat pump. Type 298 was used in this analysis. The photovoltaic panel was considered poly-crystalline cell type of $305 \mathrm{Wp}$. Under standard test condition (radiation of $1000 \mathrm{~W} / \mathrm{m}^{2}$ and cell temperature of $25^{\circ} \mathrm{C}$ ), the maximum efficiency of this PV system is $16 \%$ (Canadian Solar, 2014). The modified model of the archetype house was run for the whole year to predict the hourly thermal energy generation and electricity produced from the BIPV/T system, and the temperature of the air coming out from the PV/T channel. This air is the source of the heat pump instead of the ambient air. The south roof area is $46.44 \mathrm{~m}^{2}$, which means it could be covered by 25 of $1.66 \mathrm{~m} \times 1.00 \mathrm{~m} \mathrm{PV} / \mathrm{T}$ panels ( 5 rows, each has $5 \mathrm{PV} / \mathrm{T}$ panels). The collector width is set equal to the PV/T panel length. The length of the collector is along the direction of the air flow through the channel and the width of the collector is across the direction of the air flow through the channel.

The results from the simulation were used to calculate the saving in energy and its cost, to predict the potential improvement in heat pump performance, and to estimate the potential GHG 
emission reduction from electricity produced by the PV panels. The simulation was run for the whole year using the weather data file for Toronto (TMY2). The weather file used to simulate the model is the metropolitan Toronto weather available in the TRNSYS 17 library (TRNSYS17, 2012). The developed TRNSYS model was also simulated for different regions in Canada to estimate the performance of the heat pump of the heating season for the combined system. Figure 5-2 shows the methodology used in this chapter.

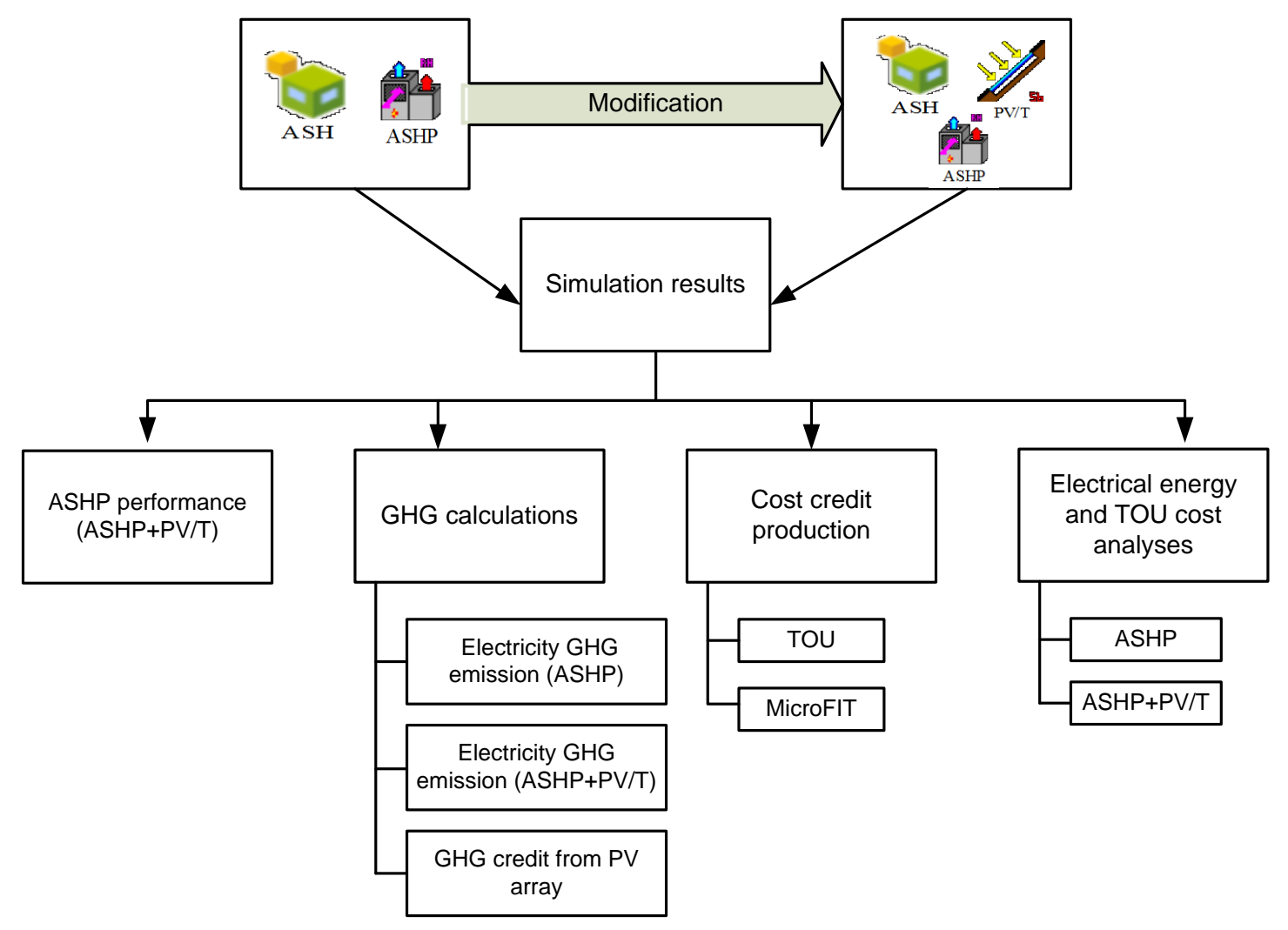

Figure 5-2: The overall methodology used in this study 


\subsection{Enhancement of the heat pump performance}

In this section, analysis for possible improvement in the heat pump performance for combining PV/T system with a two-stage variable capacity air-source heat pump at the Archetype Sustainable Archetype House (House A) was conducted.

The air source heat pump (ASHP) is one of the key technologies, which can enable buildings to eliminate the use of natural gas. However, their usage is constrained in Canada due to their reduced performance in very cold conditions since heat pump coefficient of performance (COP) depends strongly on the source temperature. In winter time, ambient air temperature falls much below freezing. Therefore, heat pump capacity and coefficient of performance (COP) decrease as the source temperature drops below zero (Routh et al., 2009).

The relationship between source temperature, for instance, the ambient temperature, and the COP of the heat pump used in ASH was established experimentally and is shown in Figure 5-3; the heating test period was between December 1, 2010 to February 9, 2011 and the indoor temperature was set at $21^{\circ} \mathrm{C}$ (Safa et al., 2015a). The correlated equation of the heating COP (Equation 5-1) was used to estimate the improved COP of the heat pump when it is connected with the PV/T array for heating purpose, which means that the source temperature for the heat pump is the temperature of the outlet air from the PV/T array.

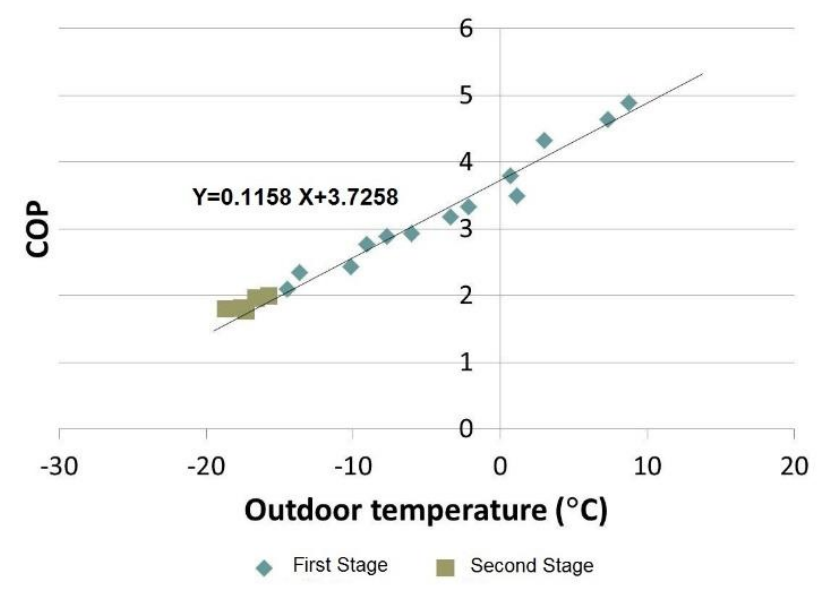

Figure 5-3: ASHP heating COP vs outdoor temperature at Archetype Sustainable House in Toronto during winter test (Dec. 1, 2010-Feb. 9, 2011) (Safa et al., 2015a)

Each PV/T panel was considered as a single thermal air node integrated on the roof during the simulation. That means the output of each PV/T panel was obtained individually, and then this 
output was considered the input for the next PV/T panel. The last one was connected to the heat pump. Since the air leaving the PV/T system with temperature, $\mathrm{T}_{\text {out }}$, was considered as the source of the heat pump, $\mathrm{T}_{\mathrm{amb}}$ in Equation (5-1) becomes $\mathrm{T}_{\text {out }}$. Consequently, the COP of ASHP would be improved. As a result, the electricity consumed by the heat pump decreased for the same hourly heating demand of House A. The seasonal heating COP of ASHP in House A was obtained as 2.74 (Safa et al., 2015a). Figure 5-4 shows the seasonal heating COP by using the preheated air from the BIPV/T system as the source of the ASHP for heat production.

$$
\mathrm{COP}=0.1158 \mathrm{~T}_{\mathrm{amb}}+3.7258
$$

As stated in Section 3.5.2, a rise in air mass flow rate leads to a significant increase in useful thermal energy from the PV/T system. However, as the air mass flow rate through the PV/T collector increases, the air temperature rise through the collector decreases rapidly, which negatively affects the COP of the heat pump (see Figure 5-4). In Figure 5-4(a), in which $\mathrm{N}_{\mathrm{S}}=5$, the values of COP are higher than those in Figure 5-4(b) and Figure 5-4(c). This is because the more PV/T systems connected in series, the warmer air is generated. In addition, when the duct depth of the PV/T system is reduced from 76 to $38 \mathrm{~mm}$ (3 to $1.5 \mathrm{in}$.), the COP increases due to higher heat transfer coefficient corresponding to higher velocity. The maximum COP was achieved with low duct depth $(\mathrm{d}=38 \mathrm{~mm})$ and low row air mass flow rate $(\dot{\mathrm{m}}=0.03 \mathrm{~kg} / \mathrm{s})$; the values are 3.41, 3.43, and 3.45 for $\mathrm{N}_{S}=3, \mathrm{~N}_{\mathrm{S}}=4$ and $\mathrm{N}_{\mathrm{S}}=5$, respectively. So, five PV/T panels connected in series with low air flow rate is preferred to boost the heat pump COP; but, on the other hand, the combined system needs enough air flow rate in the source side of the heat pump, which means adequate thermal energy to be absorbed by the evaporator in heating season. This point should be considered to maximize the performance of the whole system. Therefore, air mass flow rate through the PV/T collectors should match the required air flow over the heat pump outdoor coil according to the manufacturer manual. 


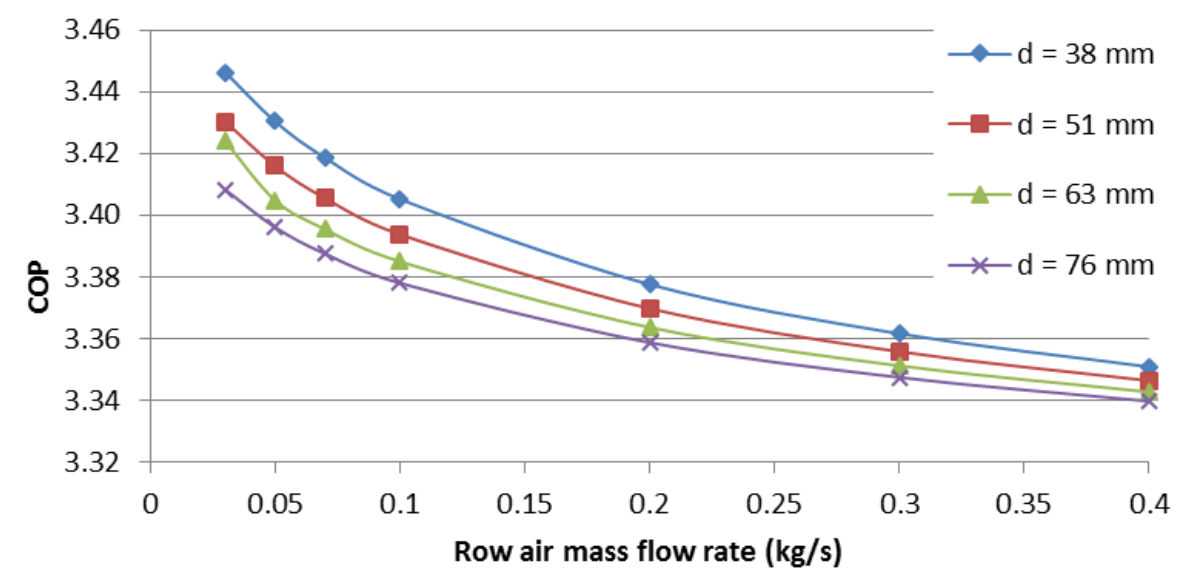

(a)

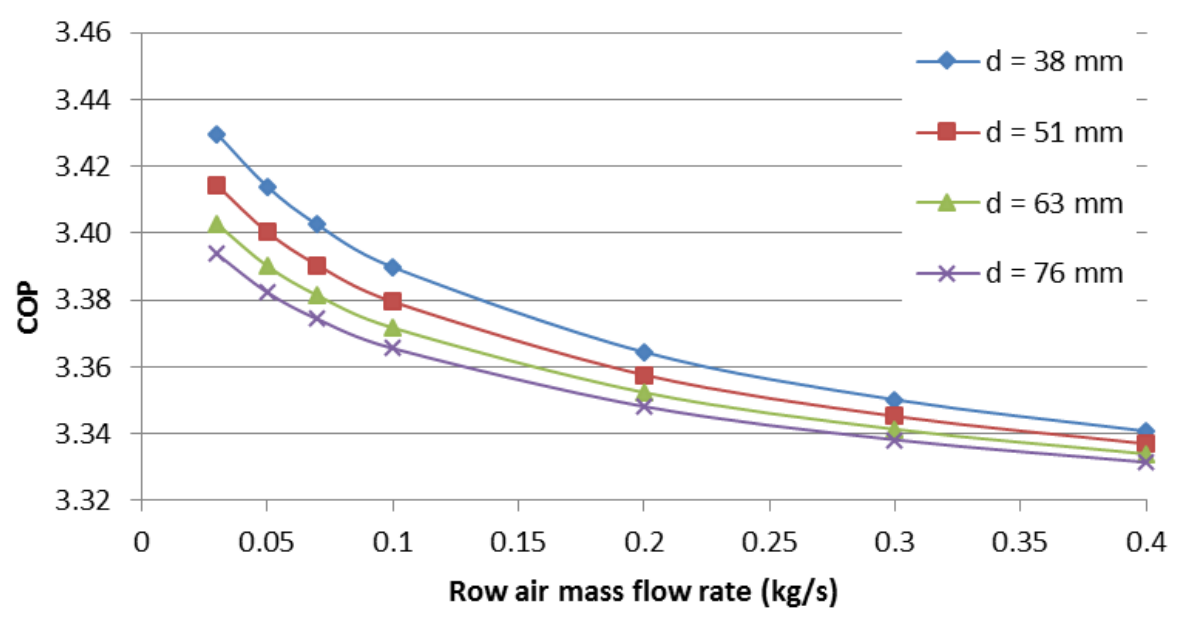

(b)

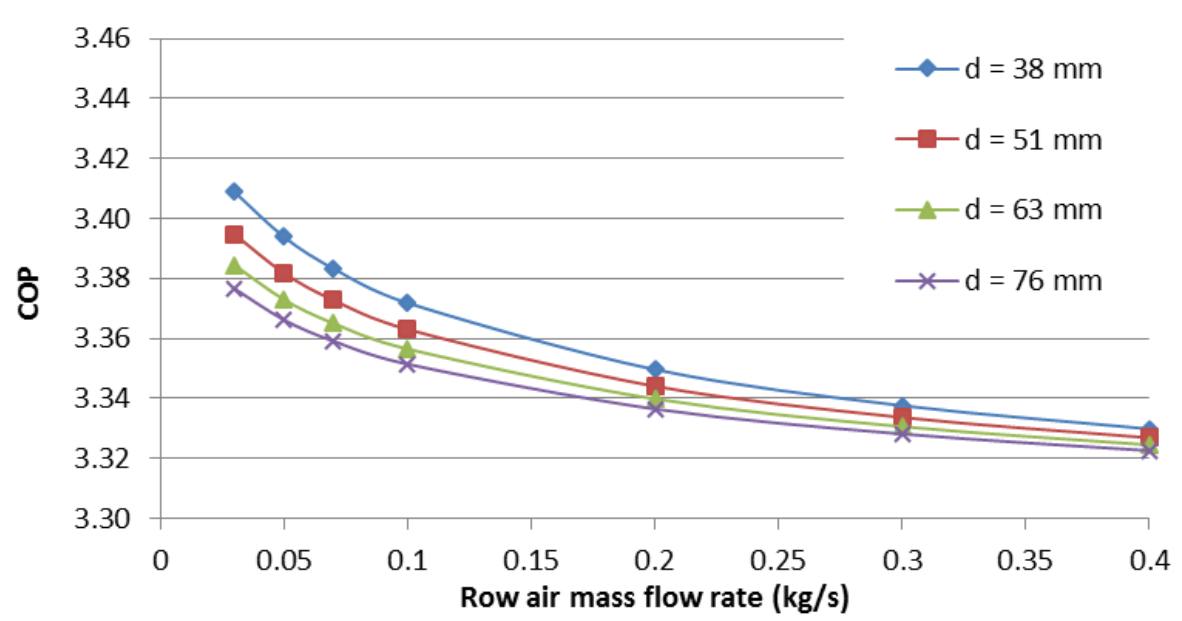

(c)

Figure 5-4: Seasonal heating COP for different depths and different row air mass flow rates:

(a) $\mathrm{N}_{\mathrm{S}}=5$, (b) $\mathrm{N}_{\mathrm{S}}=4$, and (c) $\mathrm{N}_{\mathrm{S}}=3$ 
Mitsubishi Electric Company manufactured the heat pump in ASH, model (PUZHA36NHA), the required maximum air flow over the outdoor unit is 3530 CFM (which is the maximum CFM when the heat pump is running at full load), equivalent to 706 CFM per row for the considered $5 \times 5 \mathrm{PV} / \mathrm{T}$ panels. So, the mass flow rate of $0.4 \mathrm{~kg} / \mathrm{s}$ per row was considered to match maximum outdoor coil air flow rate of the heat pump.

Figure 5-5 shows the total incident solar radiation received by the PV/T array and hourly thermal energy obtained from the PV/T array for the entire winter season during the sunshine hours. This thermal energy represents the heat extracted by the flowing air under the PV panels. It is found that there are negative values of thermal energy when the solar radiation amount is less than $150 \mathrm{~kJ} / \mathrm{h} \cdot \mathrm{m}^{2}$. This happens when there is radiative cooling (the heat is transferred toward the sky). The low intensity of radiation usually happens in early morning, late afternoon and on cloudy days. When there is not enough solar radiation, the outlet air temperature from the PV/T channel is less than the ambient air temperature. Therefore, these low values of radiation were not considered in the analysis.

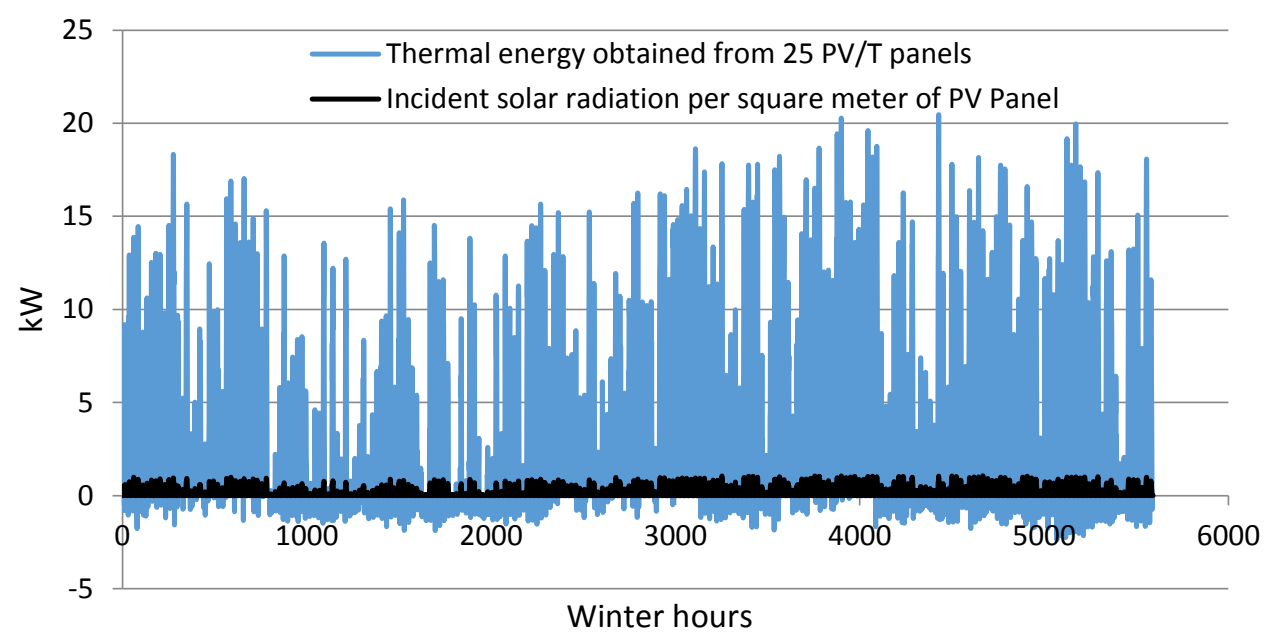

Figure 5-5: Hourly total available radiation on tilted surface and total thermal energy obtained from roof integrated $5 \times 5 \mathrm{PV} / \mathrm{T}$ array for the archetype sustainable house in Toronto area

\subsection{Greenhouse gas emission (GHG) analysis}

Greenhouse gas (GHG) emissions are the result of the consumption of fossil fuels related to the energy demand. The GHG emissions in 2010 was $391.6 \mathrm{MtCO}_{2} \mathrm{e}$, out of which $40.7 \mathrm{MtCO}_{2} \mathrm{e}$ 
were generated from residential sector. The main part of GHG emission in residential sector was from space heating $\left(30.8 \mathrm{MtCO}_{2} \mathrm{e}\right)$ and water heating $\left(9.6 \mathrm{MtCO}_{2} \mathrm{e}\right)($ Energy Use Data Handbook, 2013). Thus, replacing natural gas boilers and furnaces with high efficiency technologies supported by renewable resources has the potential to significantly lower GHG emissions. The Ontario Government target is to have a 19\% reduction in GHG emissions by 2014 and a $27 \%$ reduction by 2020 (Environmental Commissioner of Ontario, 2012). The government codes and polices have promoted energy efficiency and positively influenced the design and construction of new buildings. However, population growth, economic development and rising living standards have outpaced these gains. Replacing large-scale, fossil fuel-based energy generation with distributed energy generation from renewable resources has been identified as a potential way to significantly lower GHG emissions.

It was found that the annual electricity production from the $25 \mathrm{PV}$ panels were $7339 \mathrm{kWh}$, $7995 \mathrm{kWh}$ and $8276 \mathrm{kWh}$ for $0 \mathrm{~kg} / \mathrm{s}, 0.1 \mathrm{~kg} / \mathrm{s}$ and $0.4 \mathrm{~kg} / \mathrm{s}$ air flow rate per row, correspondingly. The annual electricity generation from the PV/T array was increased by $937 \mathrm{kWh}$ with air mass flow rate of $0.4 \mathrm{~kg} / \mathrm{s}$ comparing with electricity generation from the PV array with zero air flow rate. The electrical performance of the PV/T panels is boosted by high air flow rates. The high air flow rates enhance the rates of heat transfer from the back of the photovoltaic panels to the flowing air inside the channel, reducing the operating temperature of the PV cells and increasing the electrical power output. Figure 5-6 shows the monthly electricity generated from 25 PV panels integrated on the south facing roof of ASH in Toronto.

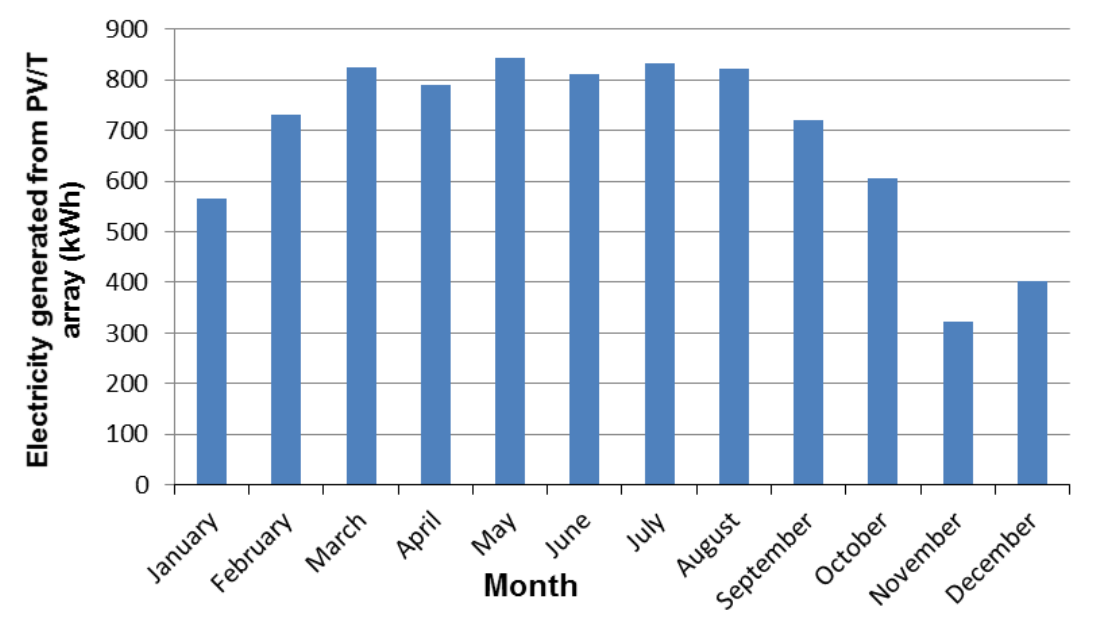

Figure 5-6: Monthly electricity generated by the BIPV/T system in Archetype Sustainable House in Toronto 
The energy cost saving and GHG emission reduction are directly related to onsite electricity generation from a PV/T system. Using renewable energy is a key factor to reduce the consumption of fossil fuel and its associated GHG emission. Usually, an average GHG emission intensity factor is used to calculate the amount of GHG emission from electricity generation (Guler et al., 2008). The average GHG intensity factor is the amount of GHG emissions produced as a result of generating one $\mathrm{kWh}$ of electricity. Using the average value of GHG emission factor neglects to show the changes in emission factors throughout the day. Gordon and Fung (2009) developed a method to estimate hourly, monthly and seasonal GHG emission factors ( $\mathrm{g}$ of $\mathrm{CO}_{2} / \mathrm{kWh}$ ) due to total electricity generation mix for the Province of Ontario. The hourly greenhouse gas emission factor (GHGIFh) was proved to be the most accurate. GHGIFh is based on the hour-by-hour demand of electricity in Ontario from nuclear, coal, hydro, natural gas and wind. The hourly values of GHGIFh for 2004, 2005 and 2006 were presented (Gordon and Fung, 2011). In order to assess accurately the GHG reduction potential from renewable energy technologies, it is better to use hourly time dependent coal GHG emission factor. Data for 2006 were used to obtain the hourly GHG emission as a result of electricity demand by the heat pump (this electricity demand does not include outdoor fan demand). Equations (5-2) and (5-3) were used to calculated annual GHG emission due to electricity consumed by the heat pump with and without PV/T system, respectively:

$$
\begin{aligned}
& G H G_{y r(A S H P)}=\sum_{i=1}^{8760} e A S H P(i) \times G H G I F_{h}(i) \\
& G H G_{y r(A S H P / P V T)}=\sum_{i=1}^{8760} e A S H P / P V T(i) \times G H G I F_{h}(i)
\end{aligned}
$$

Where,

$G H G_{y r(A S H P)}=$ annual GHG emission due to electricity demand by ASHP $\left(\mathrm{g} \mathrm{CO}_{2}\right)$

$G H G_{y r(A S H P / P V T)}=$ annual GHG emission due to electricity demand by ASHP + PV/T $\left(\mathrm{g} \mathrm{CO}_{2}\right)$

$e A S H P=$ electricity consumed by ASHP $(\mathrm{kWh})$

$e A S H P / P V T=$ electricity consumed by ASHP $+\mathrm{PV} / \mathrm{T}(\mathrm{kWh})$

$G H G I F_{h}=$ hourly greenhouse emission intensity factor $\left(\mathrm{g}\right.$ of $\left.\mathrm{CO}_{2} / \mathrm{kWh}\right)$

$i=$ hourly simulation time step 
Figure 5-7 shows the potential monthly GHG emission reduction by $5 \times 5 \mathrm{PV} / \mathrm{T}$ array. The GHG emission credit from the electricity generated from the PV/T panels was obtained from multiplying the hourly electricity generated from the PV/T array by hourly electricity GHG emission intensity factor. It is found that using the electricity generation by 25 PV panels could eliminate $1734.7 \mathrm{~kg}$ of $\mathrm{CO}_{2} /$ year. Due to direct reduction in the electricity imported from the grid by using the PV output, the net GHG emission from net electricity demand was calculated from the following equation:

$$
G H G_{n e t}=\sum_{i=1}^{8760}[e A S H P / P V T(i)-e P V T(i)] \times G H G I F_{h}(i)
$$

Where

$G H G_{\text {net }}=$ net $\mathrm{GHG}$ emission due to net electricity demand $\left(\mathrm{g} \mathrm{CO}_{2}\right)$

$e P V T=$ electricity produced by the $\mathrm{PV} / \mathrm{T}$ array $(\mathrm{kWh})$

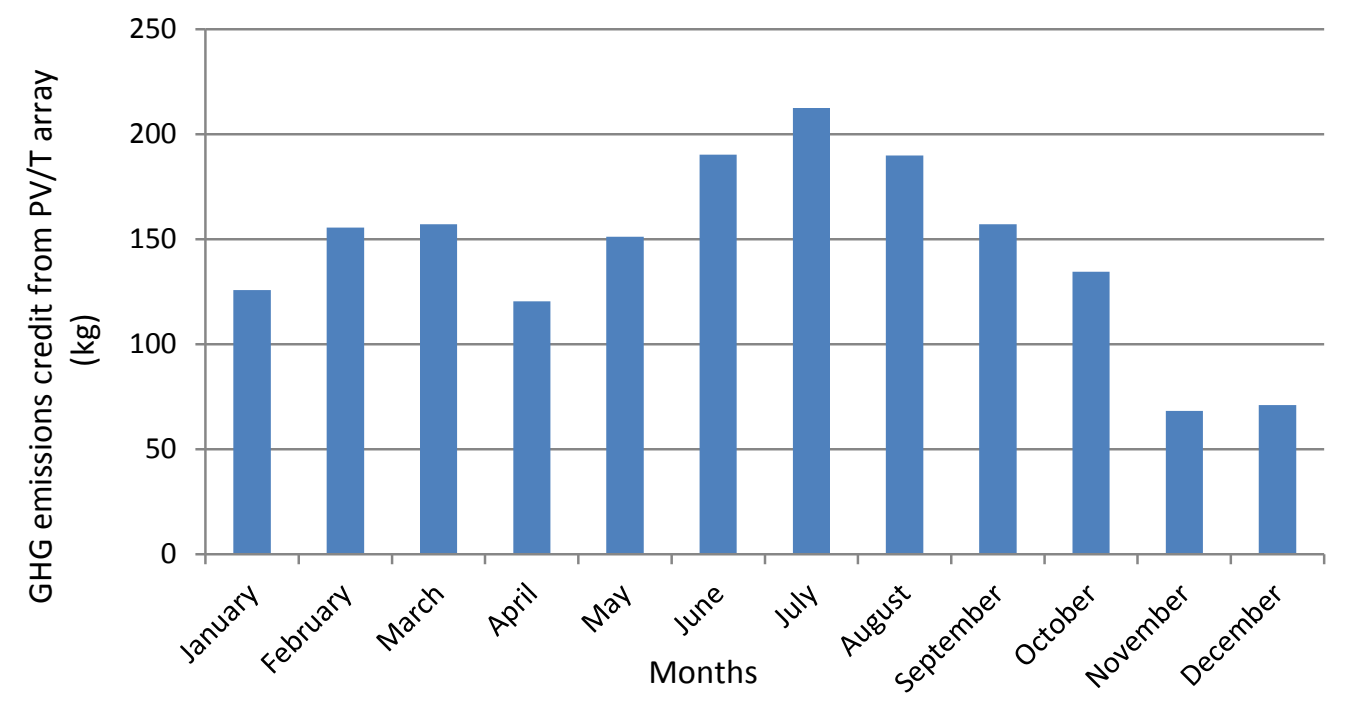

Figure 5-7: Monthly GHG emission credit from the PV/T array used in ASH

The electricity drawn by the heat pump increases with lower ambient temperature. In winter, when the preheated air from the PV/T system is used as the source for the heat pump, the electricity consumed by the heat pump decreases. Consequently, GHG emission due to the electricity demand by the ASHP is reduced. 
Figure 5-8 illustrates the comparison of the daily cumulative heat pump electricity consumption from October 1 to May 22 for House A with and without BIPV/T system. It was found that for a considered PV/T system $\left(\mathrm{N}_{\mathrm{S}}=5, \mathrm{~d}=51 \mathrm{~mm}(2 \mathrm{in})\right.$ and row mass flow rate of 0.1 $\mathrm{kg} / \mathrm{s}$ ) combined with air-source heat pump in House A, the heat pump cumulative electricity consumption (day and night) for a typical heating season could be reduced by $20.2 \%$, from 6521 $\mathrm{kWh}$ to $5114 \mathrm{kWh}$. When the analysis is based only on sunny hours, the electricity consumption of the integrated heat pump with PV/T panels would be reduced by $52 \%$ and the predicted seasonal COP of the heat pump was 5.98 .

Figure 5-9 shows the monthly GHG emission due to saving in electricity demand by the heat pump when it was linked with the PV/T array. The results showed that annual GHG emission due to electricity demand by ASHP in the house was reduced by $225 \mathrm{~kg} \mathrm{CO}_{2}$.

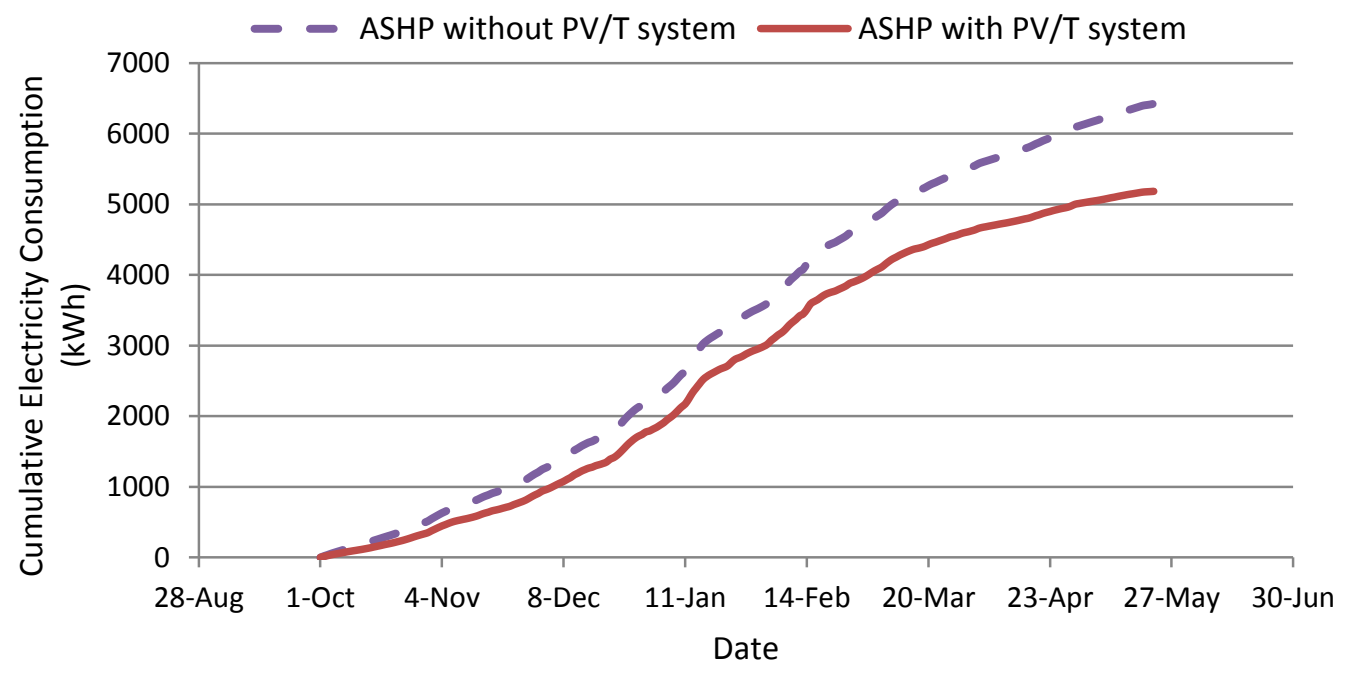

Figure 5-8: ASHP daily cumulative electricity consumption for heating season with and without PV/T system 


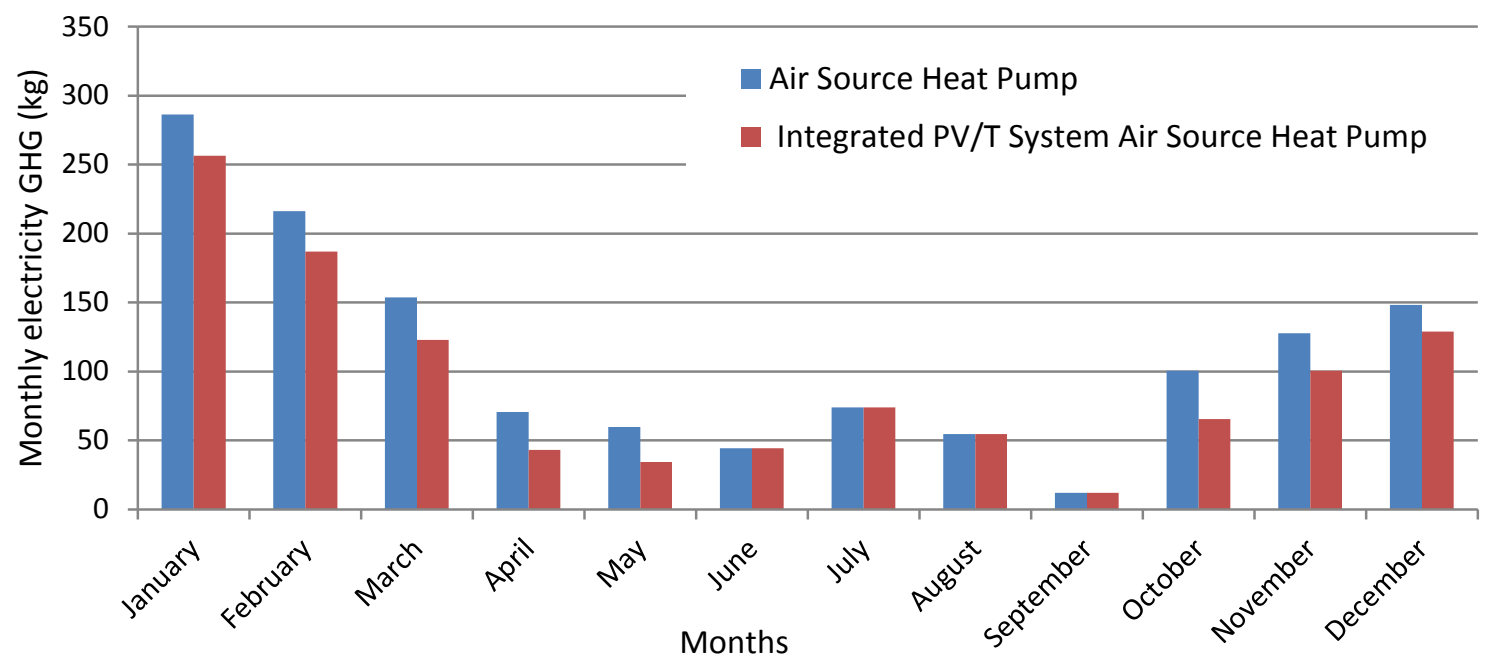

Figure 5-9: Monthly GHG emission due to electricity consumed by ASHP

The results of applying Equation (5-4) is shown in Figure 5-10, which represents the credit of using the electricity generated from the PV/T array instead of the electricity from the local grid, which means that the fossil fuel consumption and its related GHG emission are reduced. By comparing Figures 5-9 and 5-10, the GHG emissions due to electricity used by the heat pump for November, December, January and February were 100.68, 129.06, 256.38 and $187.08 \mathrm{~kg} \mathrm{CO}_{2}$, respectively, when the heat pump used the electricity from the grid. These values were significantly reduced to $32.36,57.88,130.59$ and $31.49 \mathrm{~kg} \mathrm{CO}_{2}$ due to electricity contribution of the PV/T systems to the heat pump electrical demand as shown in Figure 5-10.

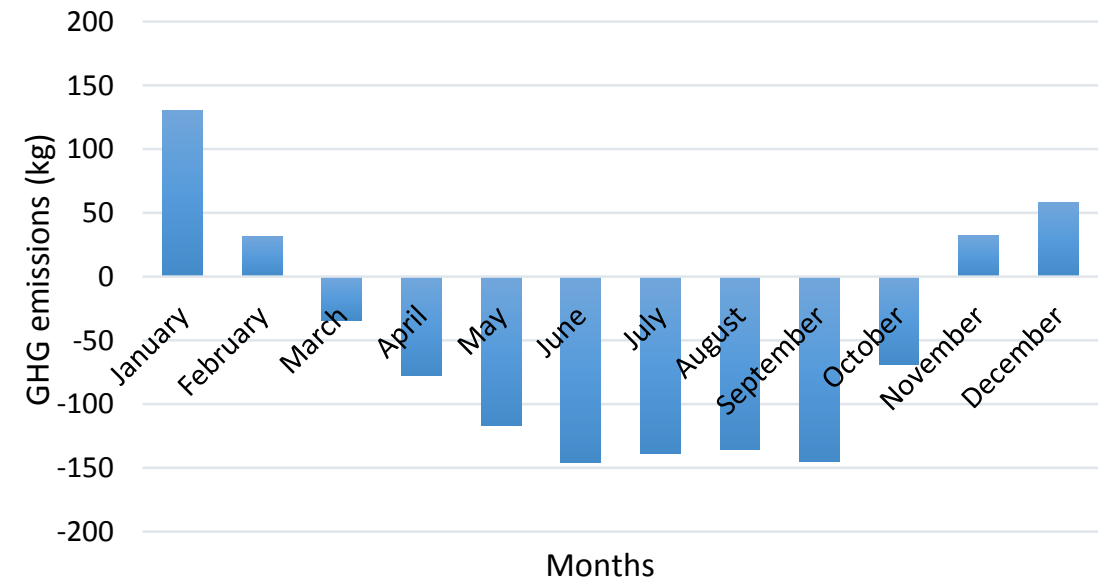

Figure 5-10: Monthly net GHG emission due to the net of electricity demand by ASHP + PV/T and produced by PV/T array 


\subsection{Electricity cost analysis}

The electricity cost was also reduced when the electricity consumed by the heat pump was decreased. Hourly electricity consumed by the ASHP and ASHP + PV/T systems was multiplied by the corresponding Time-Of-Use (TOU) price for Toronto. Equations (5-5) and (5-6) show the calculation of the annual cost of electricity at TOU price:

$$
\begin{aligned}
& \operatorname{Cost}(\text { TOU })_{y r(A S H P)}=\sum_{i=1}^{8760} \operatorname{eASHP}(i) \times \operatorname{TOU}_{P}(i) \\
& \operatorname{Cost}(T O U)_{y r(A S H P / P V T)}=\sum_{i=1}^{8760} e A S H P / P V T(i) \times \operatorname{TOU}_{P}(i)
\end{aligned}
$$

Where;

$\operatorname{Cost}(T O U)_{y r(A S H P)}=$ annual cost of electricity consumed by ASHP based on hourly TOU (\$)

$\operatorname{Cost}(T O U)_{y r(A S H P / P V T)}=$ annual cost of electricity consumed by ASHP + PV/T based on hourly TOU (\$)

TOU $_{P}=$ hourly Time-Of-Use price of Toronto $(\$ / \mathrm{kWh})$

The marginal cost of the electricity is the sum of the regulated electricity TOU price and other residential rates such as delivery rates, regulatory rates and debt retirement rates. The TOU prices for Toronto are $7.2 \phi / \mathrm{kWh}$ for off-peak time, $10.9 \phi / \mathrm{kWh}$ for mid-peak time and $12.9 \not / \mathrm{kWh}$ for on-peak time. The rates of the residential electricity charges from Toronto Hydro (2014) are:

- Delivery rates (transmission, distribution, recovery revenue rate, recovery of incremental capital module (ICM) rate): $0.03(\$ / \mathrm{kWh})$

- Regulatory rate: $0.0056(\$ / \mathrm{kWh})$

- Debit retirement rate: $0.007(\$ / \mathrm{kWh})$

The marginal cost of electricity determined with respect to TOU for Toronto region is shown in Figure 5-11. The marginal cost for off-peak, mid-peak and on-peak hours are 11.5 $\phi / \mathrm{kWh}, 15.2 \phi / \mathrm{kWh}$ and $17.2 \phi / \mathrm{kWh}$, respectively. 


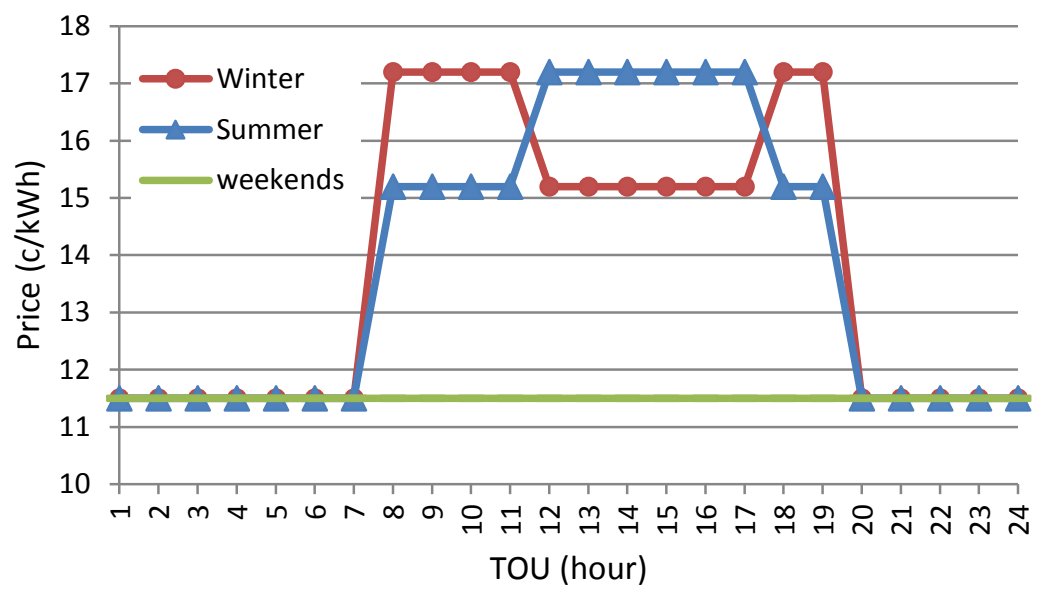

Figure 5-11: Price of electricity in Ontario since September $1^{\text {st }}, 2013$ for winter and summer

The annual cost of electricity needed to operate the heat pump in the house was $\$ 1024.5$. The use of PV/T system and air source heat pump for heating purposes resulted in direct reduction in the annual electricity cost to $\$ 837.8$. This resulted in $\$ 24$ of average monthly saving in electricity bill. Figure 5-12 shows the monthly reduction in electricity cost when the heat pump is linked with the PV/T system

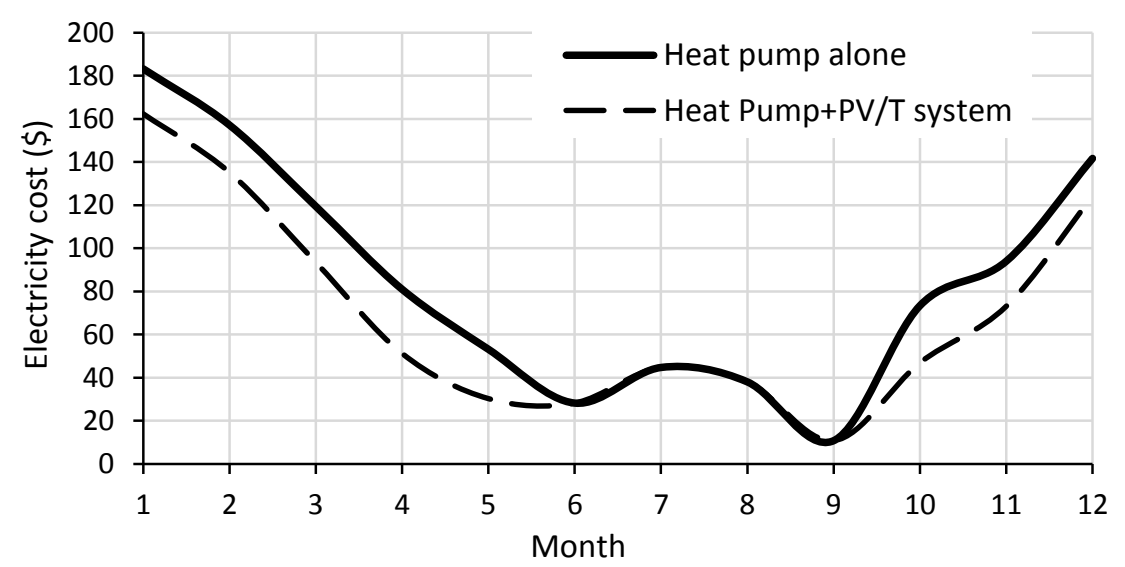

Figure 5-12: Monthly electricity cost for the ASHP working alone and combined with PV/T system

\subsubsection{Cost credit from PV/T panels}

Canada, as many countries, adopts energy policies that encourage people to expand PV panel installation and use of renewable energy. The Ontario government launched the "microFIT" Program in 2009 (ieso, 2014) to consider the advantages of producing clean energy from renewable 
sources and encourage home owners to contribute to a cleaner environment. In the microFIT program, Ontario Power Generation (OPA) pays a guaranteed price per kiloWatt hour to homeowners who develop their own renewable energy project on their property (such as a PV array on a house roof). The electricity consumers may take advantage from Bill Net Metering program (Ontario Reg. 541/05: Net Metering, 2005). The homeowner can sell the excess electricity generated by the PV array to the local grid and get credit in the electricity bill. For the combining $\mathrm{ASHP}+\mathrm{PV} / \mathrm{T}$ system, the electricity produced by a PV/T system can be used to operate the heat pump. The surplus electricity can be sold to the local grid for which the home owner can make credit. The credit of selling extra electricity to the local grid was calculated for both the net metering program, which is based on the hourly TOU price, and for the microFIT program, which is based on flat rate price; two prices were considered for the fixed rate, $80.2 \phi / \mathrm{kWh}$ and $55 \phi / \mathrm{kWh}$. Equations (5-7) and (5-8) show the calculation procedure:

$$
\begin{aligned}
& \operatorname{Cost}_{\text {NET }(\text { TOU })}=\sum_{i=1}^{8760}[e P V T(i)-e A S H P / P V T(i)] \times \operatorname{TOU}_{P}(i) \\
& \operatorname{Cost}_{\text {NET }(\text { FIT })}=\sum_{i=1}^{8760}[e P V T(i) \times \text { microFIT rate }]-\left[e A S H P / P V T(i) \times \operatorname{TOU}_{P}(i)\right]
\end{aligned}
$$

Where;

$\operatorname{Cost}_{\text {NET (TOU) }}=$ annual net electricity cost credit from PV/T electricity production based on hourly TOU price (\$)

$\operatorname{Cost}_{N E T(F I T)}=$ annual net electricity cost credit from PV/T production based on microFIT fixed price $(\$)$

microFIT rate $=$ microFIT fixed price $(\$)$

By applying Equations (5-7) and (5-8), Figure 5-13 shows monthly net electricity cost credit from PV/T electricity production based on hourly TOU price. It is shown that the cost credit of selling surplus electricity generated form the PV/T array to the local grid was $\$ 675.5$ from March to October, while there was a deficit of \$175.5 for winter months (November to February). However, the annual electricity cost credit due to selling the surplus renewable electricity generation was $\$ 500$ for the net metering program (the saving in annual electricity bills). The annual net electricity cost credit [Equation (5-8)] from microFIT guaranteed price was \$5799 and $\$ 3714$ if the home owners were paid $\$ 0.802 / \mathrm{kWh}$ and $\$ 0.55 / \mathrm{kWh}$, respectively. Table 5-1 shows 
the annual electricity cost credit from PV/T production based on TOU price and microFIT fixed price.

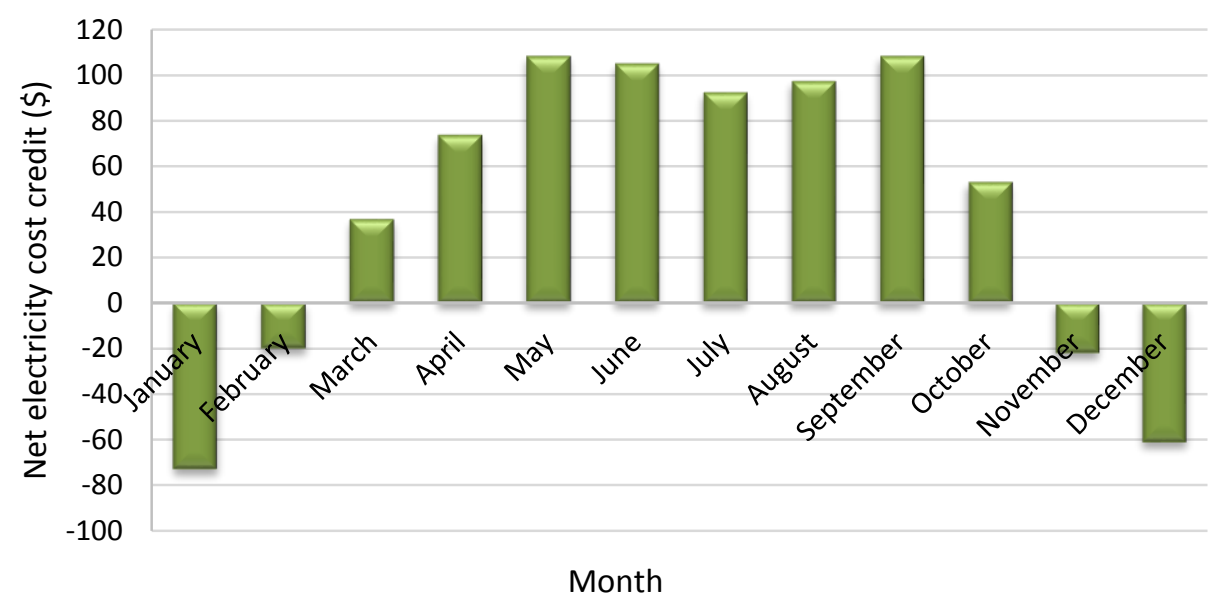

Figure 5-13: Monthly net electricity cost credit from PV/T electricity production based on hourly TOU price

Table 5-1: Annual electricity cost credit from PV/T production

\begin{tabular}{|c|c|c|c|}
\hline & \multirow{2}{*}{$\begin{array}{l}\text { Hourly Time-Of-Use price } \\
\text { (net metering program) }\end{array}$} & \multicolumn{2}{|c|}{$\begin{array}{c}\text { Fixed rate } \\
\text { (MicroFIT program) }\end{array}$} \\
\hline & & $\$ 0.802 / \mathrm{kWh}$ & $\$ 0.55 / \mathrm{kWh}$ \\
\hline $\mathrm{PV} / \mathrm{T}$ & $\$ 1338$ & $\$ 6,637.0$ & $\$ 4,552$ \\
\hline $\mathrm{PV} / \mathrm{T}+\mathrm{ASHP}$ & $\$ 500$ & $\$ 5799$ & $\$ 3714$ \\
\hline
\end{tabular}

\subsection{Solar assisted heat pump performance in selected Canadian regions}

The TRNSYS model of House-A, together with heat pump and PV/T panels, was run in different locations in Canada to estimate the heating season COP of the heat pump in these cities when it is integrated with the PV/T system. The model was simulated for Halifax, Vancouver, Edmonton and Montreal. Toronto weather file, which was used in the simulation in Section 5.2, was replaced by the weather file of each city. The estimated total energy consumed by the heat pump included the electricity consumed by the compressor and the outdoor fan. A good reference of the house heating demand in a selected area is the heating degree-days. The TRNSYS weather 
files of the selected cities were used to obtain the building heating degree-days. The base temperature was $18^{\circ} \mathrm{C}$ for heating. The results are given in Table 5-2. It can be seen that the best improvement in COP was for Vancouver since the weather is warmer than the other cities. The lowest COP improvement was for Edmonton due to very cold ambient temperature and low solar intensity. Therefore, a supplementary heat source would be required.

Table 5-2: Analysis results for selected Canadian regions

\begin{tabular}{|c|c|c|c|c|c|c|c|c|}
\hline \multirow{2}{*}{ City } & \multirow{2}{*}{$\begin{array}{l}\text { Max. } \\
\text { heating } \\
\text { load } \\
(\mathrm{kW})\end{array}$} & \multirow{2}{*}{$\begin{array}{l}\text { Minimum } \\
\text { outdoor } \\
\text { temperature } \\
\left({ }^{\circ} \mathrm{C}\right)\end{array}$} & \multirow{2}{*}{$\begin{array}{c}\text { Annual } \\
\text { heating } \\
\text { degree days } \\
\left({ }^{\circ} \mathrm{C} \text {-days }\right)\end{array}$} & \multicolumn{2}{|c|}{ ASHP working alone } & \multicolumn{2}{|c|}{$\begin{array}{l}\text { ASHP integrated with PVT } \\
\text { system }\end{array}$} & \multirow[b]{2}{*}{$\begin{array}{c}\text { COP } \\
\text { increase } \\
(\%)\end{array}$} \\
\hline & & & & $\begin{array}{c}\text { Total energy } \\
\text { consumption } \\
(\mathrm{kWh})\end{array}$ & $\begin{array}{l}\text { Heating } \\
\text { season } \\
\text { COP }\end{array}$ & $\begin{array}{l}\text { Total energy } \\
\text { consumption } \\
(\mathrm{kWh})\end{array}$ & $\begin{array}{l}\text { Heating } \\
\text { season } \\
\text { COP }\end{array}$ & \\
\hline Toronto & 6.76 & -22.2 & 4122 & 6521 & 2.74 & 5334 & 3.35 & 22 \\
\hline Halifax & 6.48 & -19.8 & 4297 & 6091 & 3.61 & 5273 & 4.17 & 15 \\
\hline Vancouver & 4.19 & -5.7 & 3034 & 4305 & 4.46 & 3549 & 5.41 & 21 \\
\hline Edmonton & 7.48 & -30.6 & 5514 & 10249 & 2.63 & 9138 & 2.94 & 12 \\
\hline Montreal & 7.33 & -24.7 & 4460 & 8148 & 2.98 & 7099 & 3.42 & 15 \\
\hline
\end{tabular}

\subsection{Summary and conclusion}

The potential improvement in the heat pump performance, saving in electricity cost and the reduction in GHG emission of combining a Building Integrated Photovoltaic-Thermal (BIPV/T) Collector and an Air Source Heat Pump (ASHP) were conducted. The credit of selling the excess electricity produced by the PV panels to a local grid was also calculated. The calculations were done based on the simulation results for the Toronto area. The results show that the air mass flow rate and the duct depth have a similar effect on the COP. In other words, low air mass flow rate and low duct depth enhance the COP. It was found that the preheated air generated from BIPV/T systems fed into the ASHP reduces the electricity consumed to operate the heat pump by $20.2 \%$. It was found that the COP was increased from 2.74 to a maximum value of 3.45 with low duct depth $(\mathrm{d}=38 \mathrm{~mm})$ and low row air mass flow rate $(\dot{\mathrm{m}}=0.03 \mathrm{~kg} / \mathrm{s})$.

Based on hourly GHG emission analysis, the GHG emission due to electricity demand was reduced by $225 \mathrm{~kg} \mathrm{CO}_{2}$. The electricity cost analysis was done according to residential electricity charges from Toronto Hydro. The use of PV/T system and air source heat pump for heating purpose resulted in average monthly savings of $\$ 24$. Home owners can sell the surplus electricity 
produced from renewable sources to the local grid. It was found that during summer months, the $\mathrm{PV} / \mathrm{T}$ array produces excess electricity while in winter months there is a deficit. However, it is important to consider both the electrical energy generated by the PV/T array and the energy required by the fan to make sure that the fan uses less energy than the electrical energy generated by ventilating the PV array. The analysis to determine the pressure drop through the PV/T channel and estimate the required power by the fan will be presented in Chapter 6 . 


\section{Chapter 6: Experimental Test Facility for BIPV/T+ASHP System}

This chapter presents:

i. The design description of the of the test hut facility at TRCA.

ii. The developed TRNSYS model for the test hut facility, the model was used to predict the heating and cooling load. The heating load for the test hut is needed to be controlled to match heating load of House A. The correlation between the test hut facility and House A was found based on the simulation results.

iii. The design of connecting an air-based solar system with an air source heat pump, including air-based thermal energy storage (TES) and different operation modes of the integrated systems (BIPV/T+ASHP+TES), which work under different weather conditions, with a particular focus on combined space heating and cooling, and domestic hot water production.

iv. The analysis of the pressure drop inside the PV/T collector for a wide range of air flow rates and different duct depths. Based on the pressure drop calculations, the electricity consumption by a fan was calculated.

v. The design of air duct system, which delivers the air from the BIPV/T array to ASHP/TES with calculation of the total pressure drop.

\subsection{Test hut facility description}

The goal of the facility is to investigate the performance of combining passive system and dynamic building envelope technologies such as hybrid solar systems, short-term thermal storage and air source heat pump to achieve near net-zero annual energy consumption. The test facility dimensions are $30 \mathrm{ft} \times 25 \mathrm{ft} \times 10.5 \mathrm{ft}(9 \mathrm{~m} \times 7.6 \mathrm{~m} \times 3.2 \mathrm{~m})$, is split into two thermally isolated identical conditioned zones (Zone 1 and Zone 2) and a mechanical room. The volumes of each of the two identical zones and the mechanical room are $135.31 \mathrm{~m}^{3}$ and $75.56 \mathrm{~m}^{3}$, respectively. The roof is constructed with Structurally Insulated Panel (SIP) with RSI-7 (R-40). The total area of the southoriented roof is $63.78 \mathrm{~m}^{2}$ with $35^{\circ}$ tilted angle. Therefore, the south facing roof could be covered by $25 \mathrm{PV} / \mathrm{T}$ panel of $7.6 \mathrm{kWp}$. The test facility is currently under construction at Toronto and 
Region Conservation Authority (TRCA)'s Kortright Centre. Figure 6-1 shows different views of the test facility. Detailed engineering drawing for the test facility is presented in Appendix D.

The walls of the test facility are Insulated Concrete Forms (ICF), which are modules used to build walls, and are more efficient than conventional walls. So, the envelope of the test facility can also be used as a thermal storage. ICF walls are constructed by assembling concrete between Polystyrene forms. The commonly used forms is either expanded Polystyrene with R-value of 3.8 per inch or extruded Polystyrene with the R-value of 5 per inch (Amvic, 2014). The foundation of the test hut is considered as an air thermal energy storage with different options. The analysis of coupling TES with BIPV/T + ASHP is done by another team member of the project, and it is out of scope of this thesis. A brief description of the thermal energy storage systems used in the test facility is presented in Section 6.4.

The mechanical systems of the test facility can be categorized into three main parts:

- Building Integrated Photovoltaic/Thermal collector (BIPV/T) system

- Heat Pump system

- Thermal Energy Storage (TES) system 


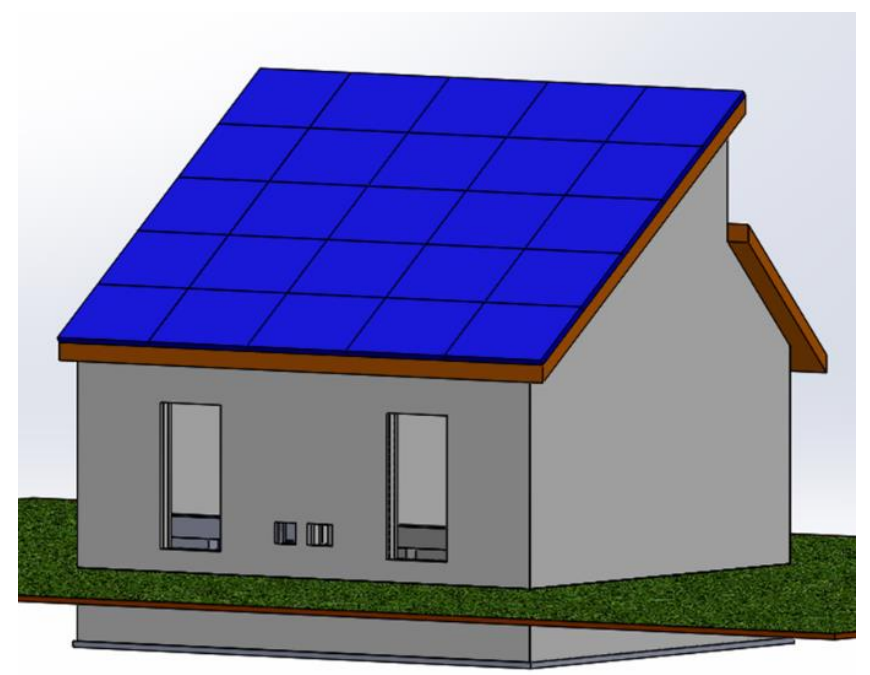

(a)

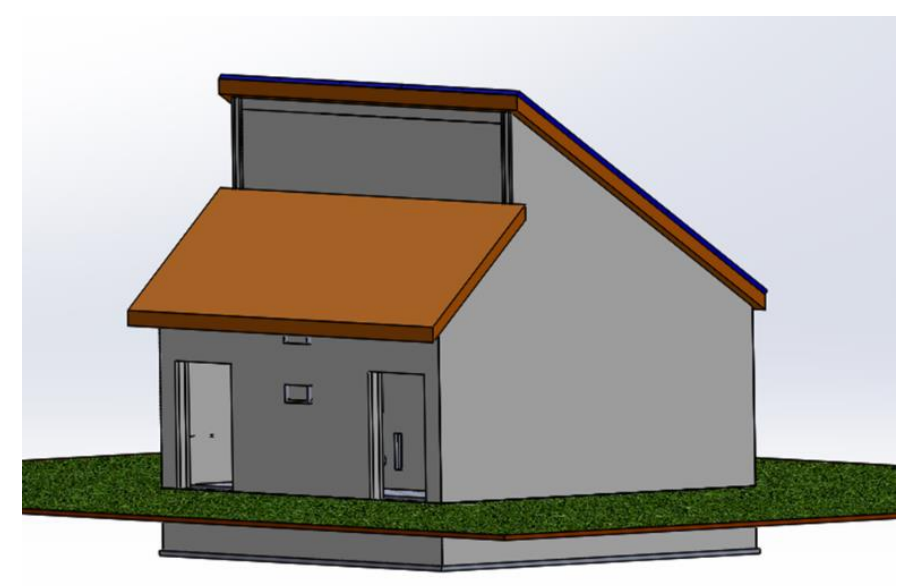

(b)

Figure 6-1: Test hut facility at TRCA (a) south view (b) north view

\subsection{Modeling and load simulation of the test hut facility}

The test hut facility was modeled using TRNSYS17. A detailed building model was developed using TRNSYS3d Plug-in for Google SketchUp, a new feature in TRNSYS17 to create the building envelope graphically. This feature enables the user to create a building model with 3D geometric surface information such as surface type (wall, ceiling, floor, etc.) and to define the category for each surface (adjacent wall, external roof, ground floor, etc.). The TRNSYS3d Plug- 
in feature is not used to model non-geometry data such as material of a wall (TRNSYS17, 2012). It is important to have the energy model not the architectural model as the user creates the SketchUp model. In other words, define thermal zones of a building. For the test facility, there are three zones (two conditioned zones and the unconditioned mechanical room). Figure 6-2 shows the 3D test hut model in TRNSYS3d SketchUp. The building model of the test hut was saved as IDF file in order to separate it from SketchUp files and be recognized by the Simulation Studio of TRNSYS software. The simulation was set up automatically by importing the IDF file using the 3D-Building Wizard in TRNSYS17 Simulation Studio. The walls material was defined as ICF materials (6 inches of concrete sandwiched between 3.25 inches expanded Polystyrene foams). The roof material was defined as standard roof material of R-40 (roof material of House A was used).

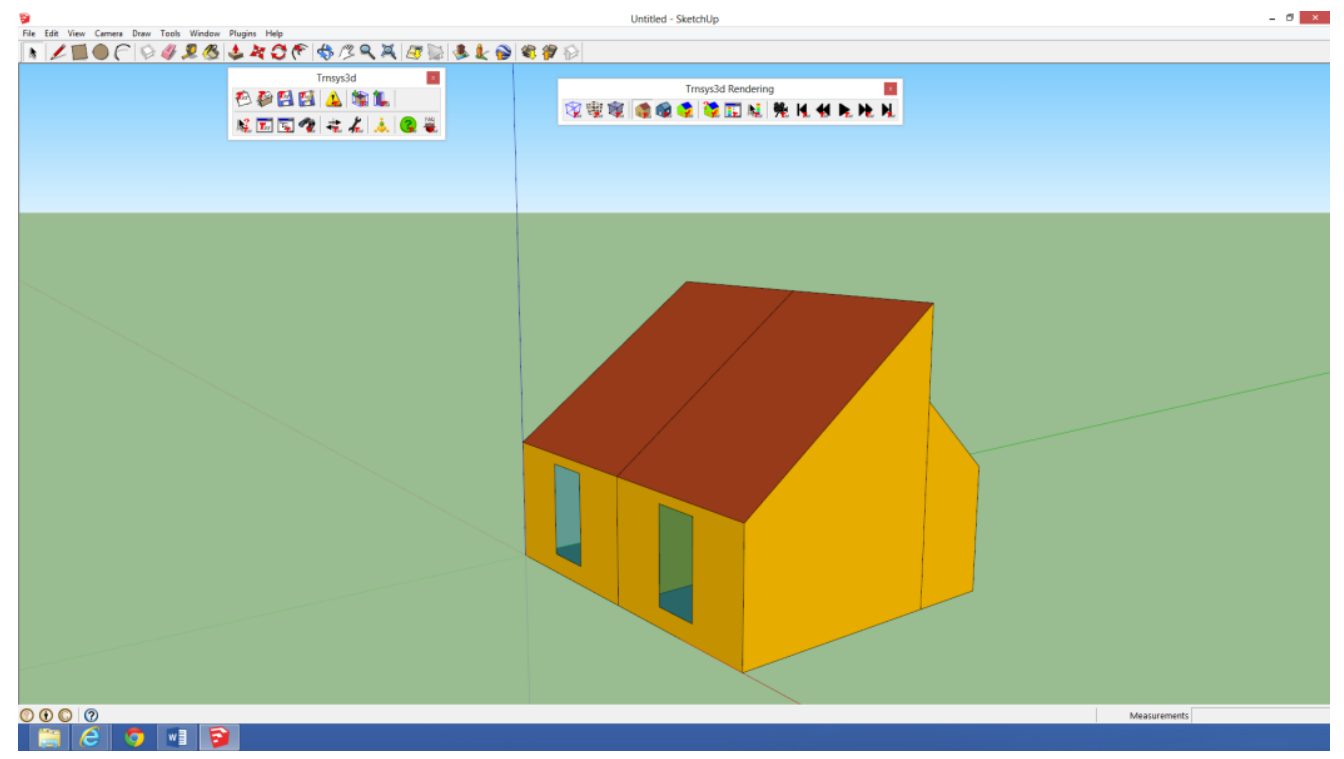

Figure 6-2: 3D test hut facility model in TRNSYS3d SketchUp

The model was simulated over a year to obtain the hourly heating and cooling demand with indoor set-point temperature of $21^{\circ} \mathrm{C}$ and $24^{\circ} \mathrm{C}$ for heating and cooling periods, respectively. Maximum calculated thermal demand of the test facility based on the simulated model was 1.7 kW. Figure 6-3 illustrates the hourly heating/cooling demand of the test facility using Meteonorm Toronto weather data. Since the size of the test facility is smaller than a single-family house, the maximum thermal demand of the building is also relatively lower than a typical residential house. The objective of the design and the application of the test hut facility is to investigate the 
performance and the feasibility of different mechanical systems such as integrated heat pump with $\mathrm{PV} / \mathrm{T}$ collectors and thermal energy storages under real life conditions. Therefore, all mechanical systems were designed/sized to match the required thermal energy for "House A" presented in Chapter 5, which is appropriate for a regular dwelling in Canada. Hence, the results of the developed House A model by Safa et al. (Safa et al., 2015a) were used for the design of the test facility's mechanical systems. The hourly demand of the House A in Toronto weather is illustrated in Figure 6-4.

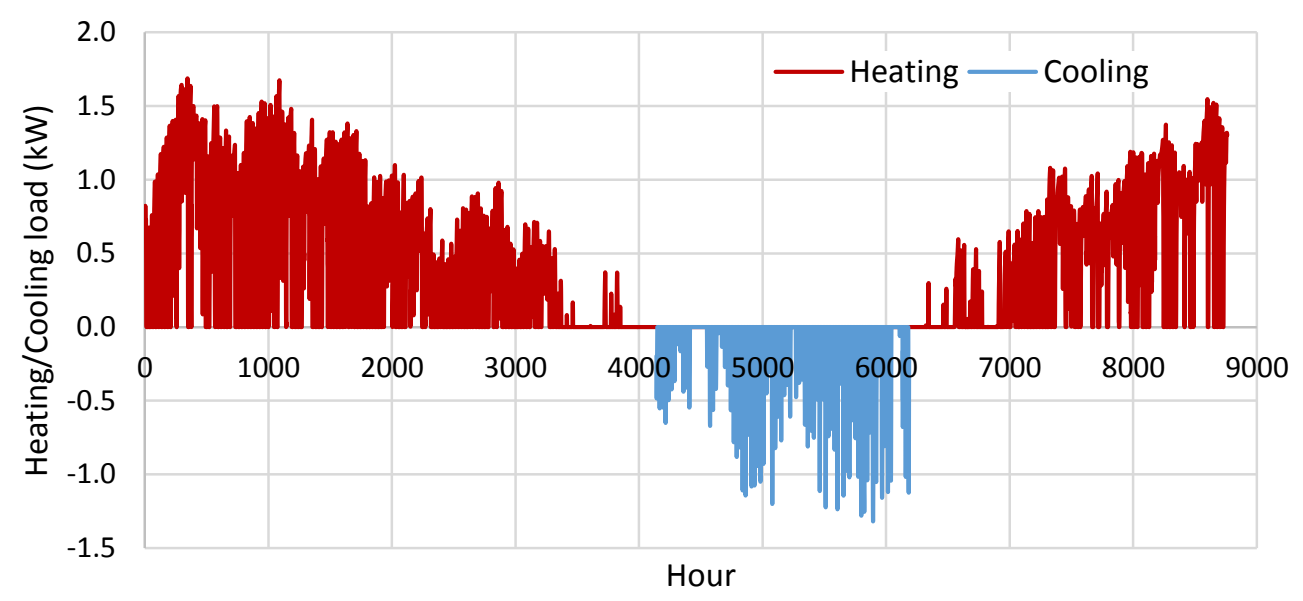

Figure 6-3: Heating/Cooling load of test hut facility

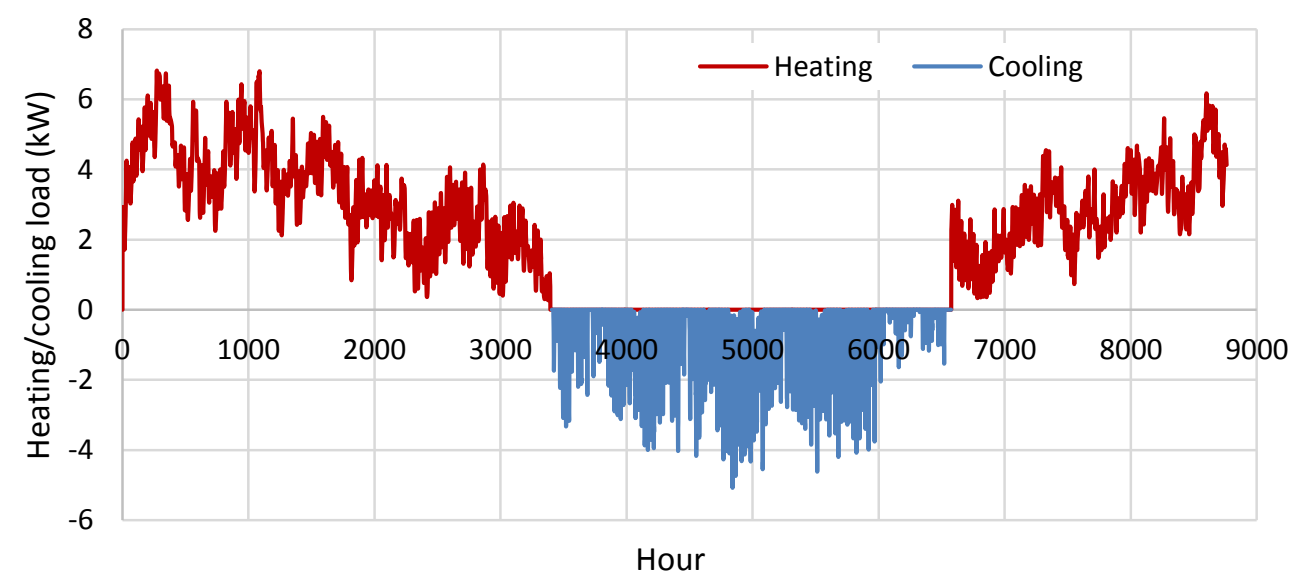

Figure 6-4: Heating/Cooling load of House A (Safa et al., 2015a) 
It is shown from Figures 6-3 and 6-4 that the heating/cooling load of the test hut facility is less than House A since the size of the test hut is smaller than House A. The thermal demand of the test hut during sunny hours in winter is small because of the two large windows in the south side of the building resulting in solar gain.

As it is mentioned earlier that the mechanical systems are designed based on House A. The heating load for the test hut is manipulated to match that of House A. Therefore, it is important to correlate the thermal demands of both building. Figure 6-5 illustrates the trend of thermal demands for both test facility and House A as a function of the outdoor temperature. It is clear from Figure 6-5 that thermal demands are higher when the outdoor temperature is lower. The thermal demands from the simulation of both buildings are in linear relation with the outdoor temperature, are presented as:

$$
\begin{aligned}
& T D_{\text {House } A}=-0.1582 \times T_{a m b}+3.3586 \\
& T D_{\text {Test facility }}=-0.0406 \times T_{a m b}+0.6034
\end{aligned}
$$

Solving Equations (6-1) and (6-2) to find the correlation between the test hut facility and House A

$$
T D_{\text {House A }}=3.8971 \times T D_{\text {Test facility }}+1.0074
$$

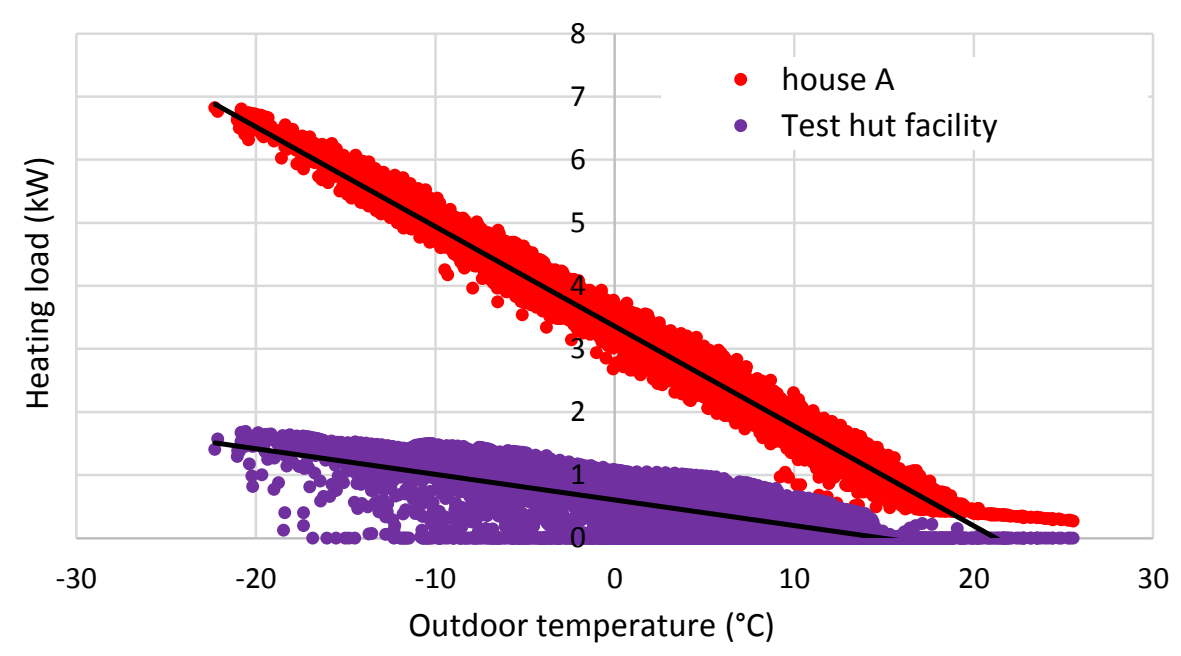

Figure 6-5: Heating load of House A and test hut facility versus outdoor temperature for Toronto 


\subsection{Coupling air based BIPV/T system with ASHP system}

Based on the literature review done in Chapter 2, most of the research covered in this review shows that the dominant source of solar assisted heat pump is liquid-based system with water thermal storage. SAHPs of this type are used only for heating purposes (space heating or hot water production). The reviewed work shows that there is a lack of investigations of connecting an air-based solar system (especially PV/T system) with an air source heat pump, including airbased thermal energy storage. It is a challenge to design an integrated system of (BIPV/T+ASHP+TES) which works efficiently under different weather conditions, with a particular focus on combined space heating and cooling, and domestic hot water production. In addition, the ducting design of the combined system itself, i.e., connecting PV/T system with heat pump and thermal energy storage system, all together, requires a complicated duct design and installation.

Figure 6-6 shows a schematic of such an integration. In order to make the integrated system works for heating, cooling, and domestic hot water production, the design should include a bypass path for driving air to/from the heat pump and to/from thermal energy storage. It is suggested to use a louver box with dampers to direct air flow, either to the heat pump or to the air thermal storage. Different coupling options should be considered depending on the season and the time during the day. Therefore, a custom-designed heat pump is needed to satisfy the required functions (cooling in summer, heating in winter, and production of domestic hot water during the entire year). In cooperation with a local industrial partner (Ecologix Heating Technologies Inc.), an air source heat pump is currently being designed to be coupled with a PV/T system while operating in different modes. The outdoor unit should be in a closed box with opening to outside for circulating the air over the outdoor coil. Figure 6-7 shows a picture for the outdoor unit of Ecologix Inc. custom-designed air source heat pump. 


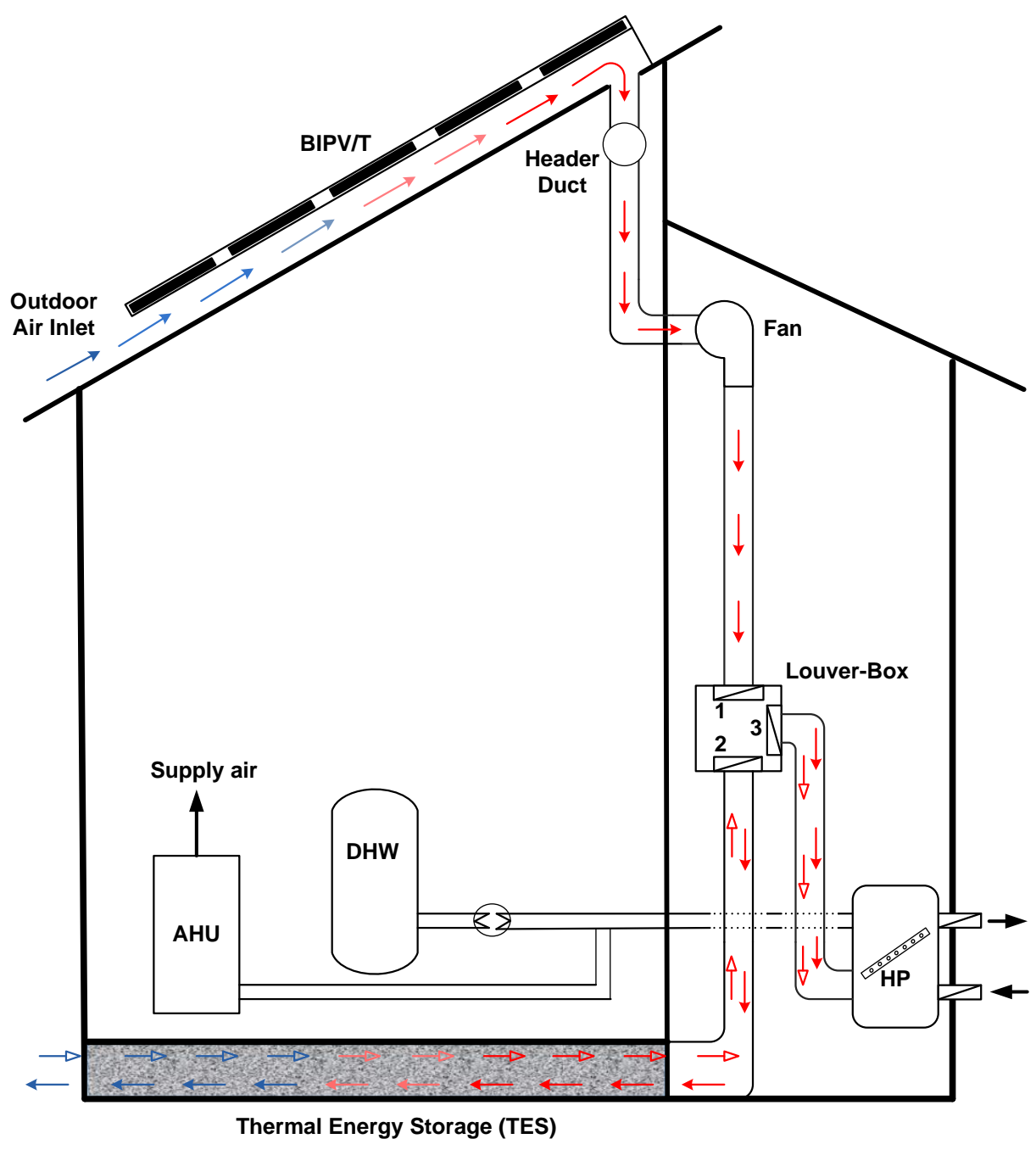

Figure 6-6: Schematic of BIPV/T system integrated with ASHP and thermal energy storage system

In winter, the source of the heat pump is the preheated air from PV/T during sunny hours (dampers 1 and 3 opened, damper 2 closed) when the space heating is required. The energy collected by the solar collector can be stored in the TES when space heating is not required (dampers 1 and 2 opened, damper 3 closed). The cold outdoor air during the night can be warmed up by the TES to enhance the ASHP performance (dampers 2 and 3 opened, damper 1 closed). In summer, the heat pump works to cool the space. In this case, the collected thermal energy from the PV/T system can be used to produce DHW directly with the ASHP or indirectly through the desuperheater of the ASHP under cooling mode. For such integration, Table 6-1 shows the different operation modes of the ASHP for the test hut facility project. 


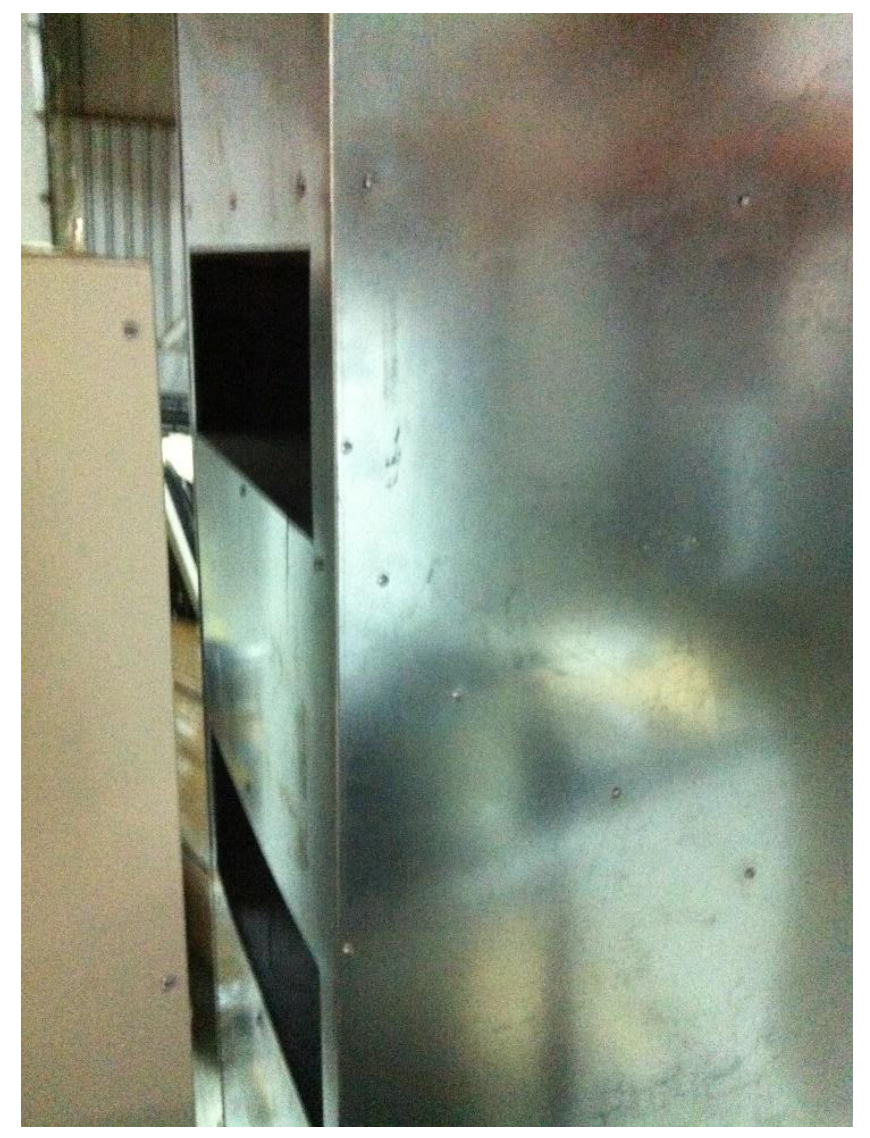

Figure 6-7: A photo for the outdoor box unit of the air source heat pump for (BIPV/T + ASHP) project at TRCA

Table 6-1: Different operation options of the ASHP for the Test hut facility

\begin{tabular}{|c|c|c|c|c|c|}
\hline \multirow{4}{*}{ శ్శ } & & Winter & \multicolumn{2}{|c|}{ Summer } & All year \\
\hline & Outdoor coil (source) & X & $X$ & X & Desuperheater \\
\hline & AHU (cooling mode) & $\downarrow$ & & $X$ & \\
\hline & AHU (heating mode) & $\mathrm{X}$ & $\downarrow$ & 1 & \\
\hline & DHW (HX) & $\mathrm{X}$ & $\mathrm{X}$ & $X$ & $X$ \\
\hline & In floor heating $(\mathrm{HX})$ & $\dot{X}$ & & & \\
\hline & & $\begin{array}{l}\text { Work individually } \\
\text { according to priory, } \\
\text { use thermal energy } \\
\text { from PV/T system }\end{array}$ & $\begin{array}{l}\text { Use thermal energy } \\
\text { collected from } \\
\text { PV/T array }\end{array}$ & & $\begin{array}{c}10 \% \text { of total } \\
\text { capacity }\end{array}$ \\
\hline
\end{tabular}




\subsection{Thermal energy storage system}

The challenge of using solar energy is that supply and demand periods may not match. The highest demand of thermal energy normally happens at nights or early mornings in winter when the sun is not available and on the other hand, the peak of the solar irradiation occurs during the day in summer when the heating is not required. Therefore, generating solar thermal/electrical energy may not be always required. Thus, storing the energy during the day and releasing it upon demand would be a wiser choice considering that a well designed sustainable building must also satisfy the thermal comfort of occupants (Ekrami et al., 2015).

The difference between supply and demand of solar generated thermal energy can be compensated by a short term thermal energy storage (TES) system such as building's façade/thermal mass (Khalifa and Abbas, 2009). Coupling the TES to the space heating operator can potentially enhance the overall performance of the building's integrated system. It means TES improves the thermal performance of the system and consequently electrical consumption of the heat pump will decrease. Additionally, TES could reduce the temperature fluctuation in the building.

There are three types of thermal energy storages included in the test facility, below is brief description of each type. More details could be found in Ekrami et al. (2015) and Ekrami et al. (2015a).

\subsubsection{Insulated Concrete Forms (ICF) walls}

In addition of using ICF as construction of the walls, it can be used as thermal mass to store thermal energy. The wall is embedded with hydronic pipes inside the concrete for the purpose of thermally charging and discharging it with preheated water. ICF wall as TES could be used as a source for the heat pump or re-use it through forced air space heating or hydronic infloor heating. The ICF walls are designed to be charged with heated water provided by an air-to-water heat pump when the sun is available and the solar assisted heat pump works in more efficient manner (Ekrami et al,. 2015b). 


\subsubsection{Ventilated sand / gravel bed}

The thermal mass of Zone 1 is four feet deep fine sand bed, which is ventilated by air pipes. The sand bed is located beneath a rigid insulation layer that separates the sand bed from concrete slab. Heated air is supplied by the BIPV/T system and is fed to the sand bed. Thermal energy will be transferred and stored into the sand during the sunny hours and can be extracted at later time when there is a demand. The stored thermal energy can be used to preheat the inlet air to the air source heat pump system during cold nights.

The foundation of Zone 2 is designed with a gravel bed or recycled concrete aggregate bed is used instead of fine sand. Since the air can passes through the voids of gravel/aggregate, there is no need for piping system. However, in order to distribute air evenly inside the bed a header/manifold is used for each of the inlet and outlet.

\subsubsection{Ventilated Concrete Slab (VCS)}

The ventilated concrete slab is used in each zone as thermal storage. Above the rigid insulation panel that separates the foundation from the slab, there is a layer of concrete with 4 inches thickness. A corrugated steel deck will be placed on top of this concrete layer during the construction. Then another concrete layer will be poured on top of the steel deck. The voids between bottom layer concrete and the corrugated steel can work as an air channel.

\subsection{Pressure drop and fan power}

As it is known, there is a trade-off between maximizing the heat removel from the PV panels and pressure drop along the PV/T duct. Increasing air mass flow rate and reducing duct depth boost heat transfer from the PV panels to the air and increase the pressure drop which is directly related to the power requirement of the fan to maintain air flow in the BIPV/T system. Therefore, it is important to consider the required fan power for forced ventilation air inside the duct. Also, it is crucial to find out the net available electrical energy produced from the PV panels, i.e. part of the electrical energy produced by the PV/T array is used to run the fan. 


\subsubsection{Pressure drop calculation for BIPV/T system}

The total head pressure is the summation of major losses and minor losses. The major head losses are due to friction losses in the duct is given by Equation (6-1), which is valid for both laminar and turbulent flows, smooth or roughness surfaces (Cengel et al., 2008):

$$
(H P)_{\text {major }}=f \frac{L}{D_{h}} \frac{V^{2}}{2 g}
$$

The parameter $f$ is the friction factor calculated from the approximate explicit relation given by Haaland in 1983 (Cengel et al., 2008) for turbulent flow:

$$
\frac{1}{\sqrt{f}} \cong 1.8 \log \left[\frac{6.9}{R e}+\left(\frac{\varepsilon / D_{h}}{3.7}\right)^{1.11}\right]
$$

For laminar flow, the friction factor is inversely proportional to Reynolds number and is independent of the roughness of the pipe surface (Cengel et al., 2008), given as:

$$
f=\frac{64}{R e}
$$

The minor losses are due to the effects of system different elements such as channel entrance, exit, elbows, bends, joints, etc., are calculated by Equation (6-2):

$$
(H P)_{\text {minor }}=\sum k_{i} \frac{V^{2}}{2 g}
$$

Since the pressure drop $(\Delta P)$ cross a duct is defined as:

$$
\Delta P=\rho_{\text {air }} g(H P)
$$

Therefore, the total pressure drop along the PV/T system is:

$$
\Delta P_{\text {Total }}=f \frac{L}{D_{h}} \frac{\rho_{\text {air }} V^{2}}{2}+\sum k_{i} \frac{\rho_{\text {air }} V^{2}}{2}
$$

The average air flow velocity $(V)$ is calculated from the relation:

$$
V=\frac{\dot{m}}{\rho_{\text {air }} A}
$$


The parameter $k$ was given the values of $0.5,1.0,0.4$ and 0.9 for the losses of entrance, exit, joints and bending (Cengel et al., 2008). The electrical power consumed by a fan is the required power to overcome the pressure loss divided by the fan efficiency and motor efficiency (Cengel et al., 2008):

$$
P_{\text {fan }}=\frac{\dot{V} \Delta P_{\text {Total }}}{\eta_{\text {Fan }} \eta_{\text {motor }}}
$$

The calculation was done for a wide range of air flow rates with different BIPV/T duct depths. The BIPV/T system is a $5 \times 5$, which will be installed on the south facing roof of the test facility. Both the fan and motor efficiencies were assumed to be $80 \%$. It was assumed that the fan operates at a constant speed whenever there is enough available solar radiation to produce electrical and thermal energy from the BIPV/T array that is ignoring the early morning and late afternoon hours. From the TRNSYS results for the $5 \times 5 \mathrm{BIPV} / \mathrm{T}$ array, it was found that the average number of daily sunny hours (the hours during which the PV/T array produces thermal and electrical energy) are 8.5 hours from October $1^{\text {st }}$ to May $31^{\text {st }}$ and 11 hours from June $1^{\text {st }}$ to September $30^{\text {th }}$. The hourly fan power consumption was calculated assuming a fan was running for 8.5 hours from October to May and for 11 hours from June to September.

Bambrook and Sproul (2012) investigated the effect of an increase in air temperature on air density for pressure drop calculations inside a PV/T system. The air density was calculated along the length of the PV/T collector as the air temperature was increased. They compared the required fan power based on temperature-dependent densities along the collector with the required fan power based on single average air density value. The study found that the difference between the two cases was $\pm 1 \%$. Therefore, they recommended using standard calculations, which are based on the average air temperature inside the PV/T duct and its corresponding air density.

Equation (6-7) was used to calculate the hourly air density inside the PV/T duct during the operation hours for a whole year. The $T_{\text {average }}$ in Equation (6-7) is the hourly mean air temperature inside the PV/T duct, which was obtained from TRNSYS simulation.

$$
\rho_{\text {air }}=\frac{P_{\text {atm }}}{R_{\text {air }} T_{\text {average }}}
$$


Figure 6-8 shows the annual fan power required to ventilate a $5 \times 5 \mathrm{PV} / \mathrm{T}$ array for a wide range of air flow rates and different duct depths. As expected, for high values of air flow rate and low values of duct depth, the pressure losses are high; correspondingly the required power by a fan also increases. Since the outlet air from the BIPV/T array is the source of the ASHP, it is very important to match the maximum total air flow for the whole PV/T array to the maximum required CFM for the outdoor coil of the heat pump. The maximum heating capacity of the custom-designed ASHP for the test hut facility is 2 tons corresonding to $2000 \mathrm{CFM}\left(0.944 \mathrm{~m}^{3} / \mathrm{s}\right)$ for the outdoor unit. Regarding Figure 6-8, for an air flow rate around 2000 CFM, the predicted fan energy was in the range of $195 \mathrm{kWh} /$ year to $21 \mathrm{kWh} /$ year corresponding to duct depth of 1.5 in and 4 in, respectively. The required energy by the fan was less than the additional electrical energy generared from the ventilated PV/T system (for duct depth of 1.5 in the extra electrical energy generated from the PV/T array was around $500 \mathrm{kWh} /$ year). Increasing the air flow rate to 3200 CFM resulted in raising the fan power to $637 \mathrm{kWh} /$ year for a 1.5 in duct depth and $73 \mathrm{kWh} /$ year for a 4 in duct depth. It was observed that the required power was very low compared to thousands of $\mathrm{kWh}$ production of electrical power from $25 \mathrm{PV}$ panels, even for small duct depth (1.5 in).

Figure 6-9 illustrates the annual net electrical power generated from $25 \mathrm{PV}$ panels if a portion of the electricity production from the BIPV/T array is used to operate a fan. The annual net electrical power was calculated using the followng Equation:

$$
\text { Annual net electrical power }=\sum_{o h=1}^{8760}\left[E(o h)-P_{f a n}(o h)\right]
$$

Where oh $=$ operation hours

It is obvious from Figure 6-9 that up to $2500 \mathrm{CFM}$, the values of a fan input power are low compared to the electricity obtained from the PV/T panels. For higher air flow rates (more than 4000 CFM), a significant amount of power is consumed by the fan especially for low duct depths (less than 2.5 in). However, for air flow rates up to $2500 \mathrm{CFM}$, the net electrical power increased with decreasing duct depth. The reason is due to higher heat transfer coefficient for lower duct depth, which removes more heat from the solar cells and consequently greater electricity production from the PV panels. 


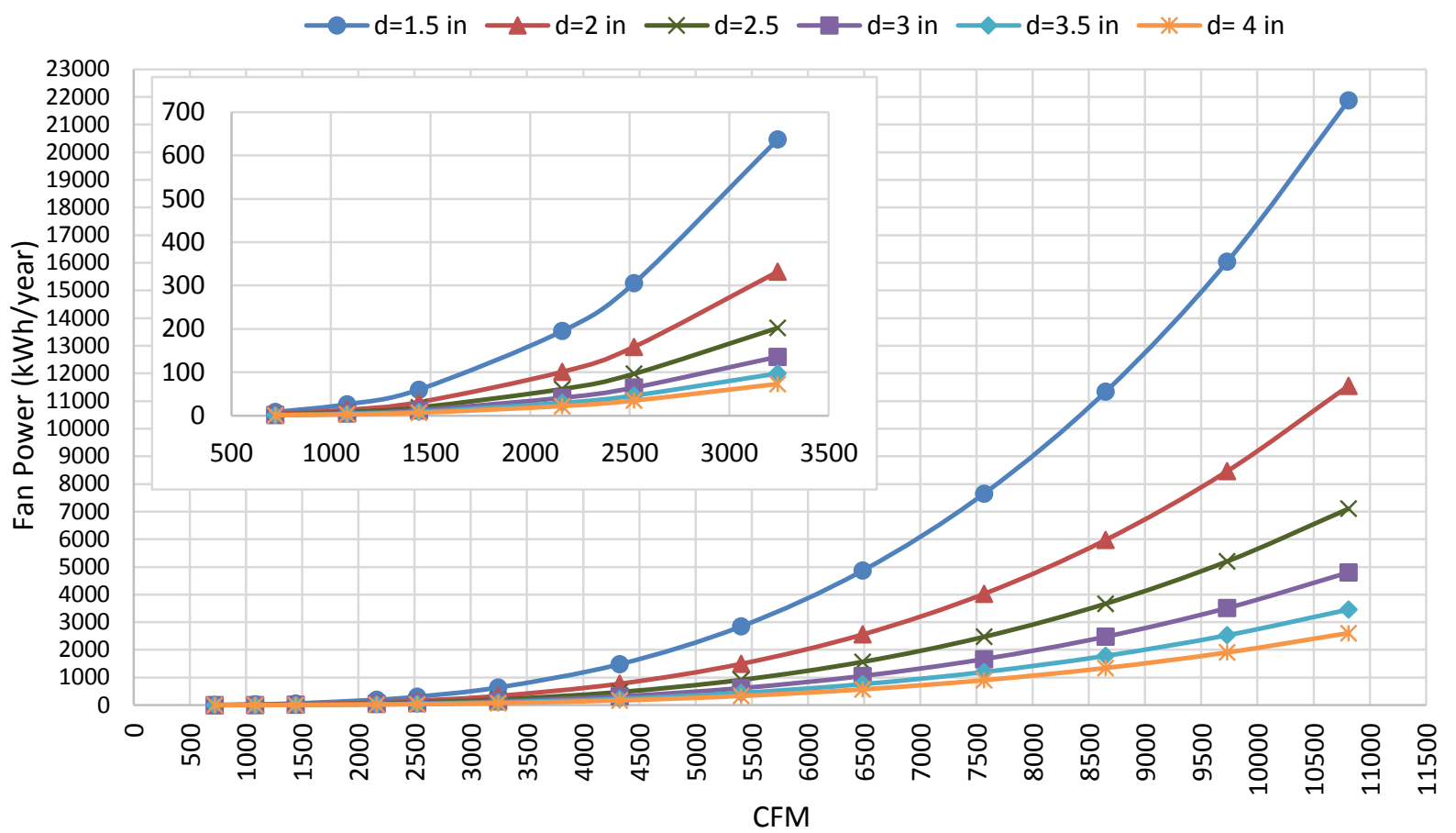

Figure 6-8: Annual fan power consumption for $5 \times 5$ BIPV/T system with different total air flow rate and different duct depth

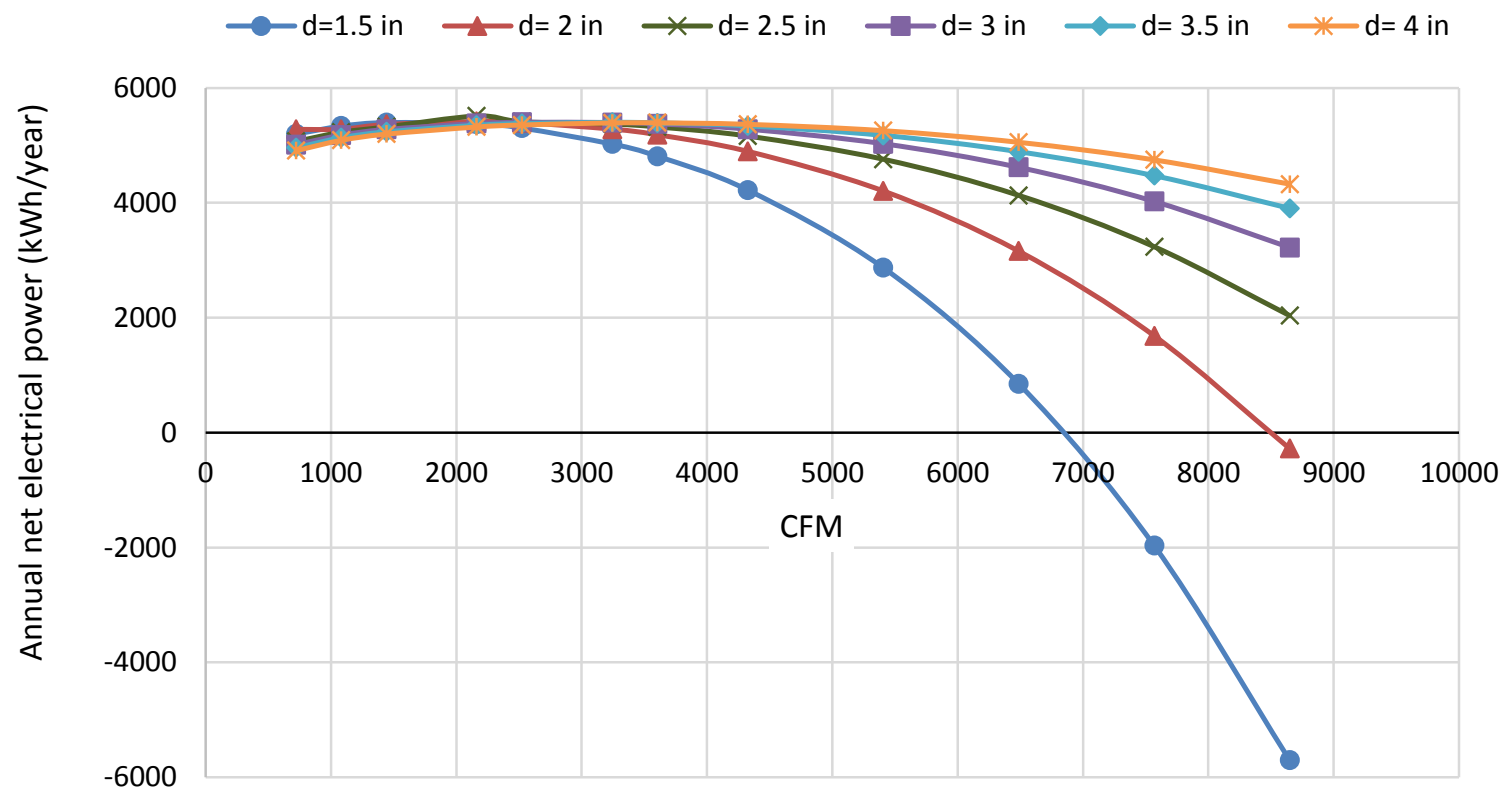

Figure 6-9: Annual net electrical energy produced from the PV/T array when part of electricity is used by a fan 


\subsubsection{Duct design and pressure drop for coupling BIPV/T system with ASHP}

In Section 6.5.1, the calculations for pressure drop was only along the BIPV/T array. However, for combining BIPV/T system with ASHP system, it is essential to consider the layout and the size of the duct system, which deliver the air from the BIPV/T array to ASHP/TES.

In order to find the total pressure for delivering air to ASHP, a duct system-sizing program called "DUCT" was used to compute sizes of air duct systems and to calculate the pressure drop (McQuiston et al., 2005). The duct system arrangement for coupling BIPV/T array with ASHP and TES systems in the test hut facility is shown in Figure 6-10. For each row of the BIPV/T array, there is a circular delivery duct underneath the upper end of the PV/T duct. The circular delivery ducts for all rows are connected by a header duct, which collect the outlet air. Since the two zones of the test facility are separated by a wall, two header duct should be used (see Figure 6-11b). For actual residential houses, the layout of an air duct system for combining BIPV/T and ASHP would be different based on the available space; for example, the space in the attic could be used.

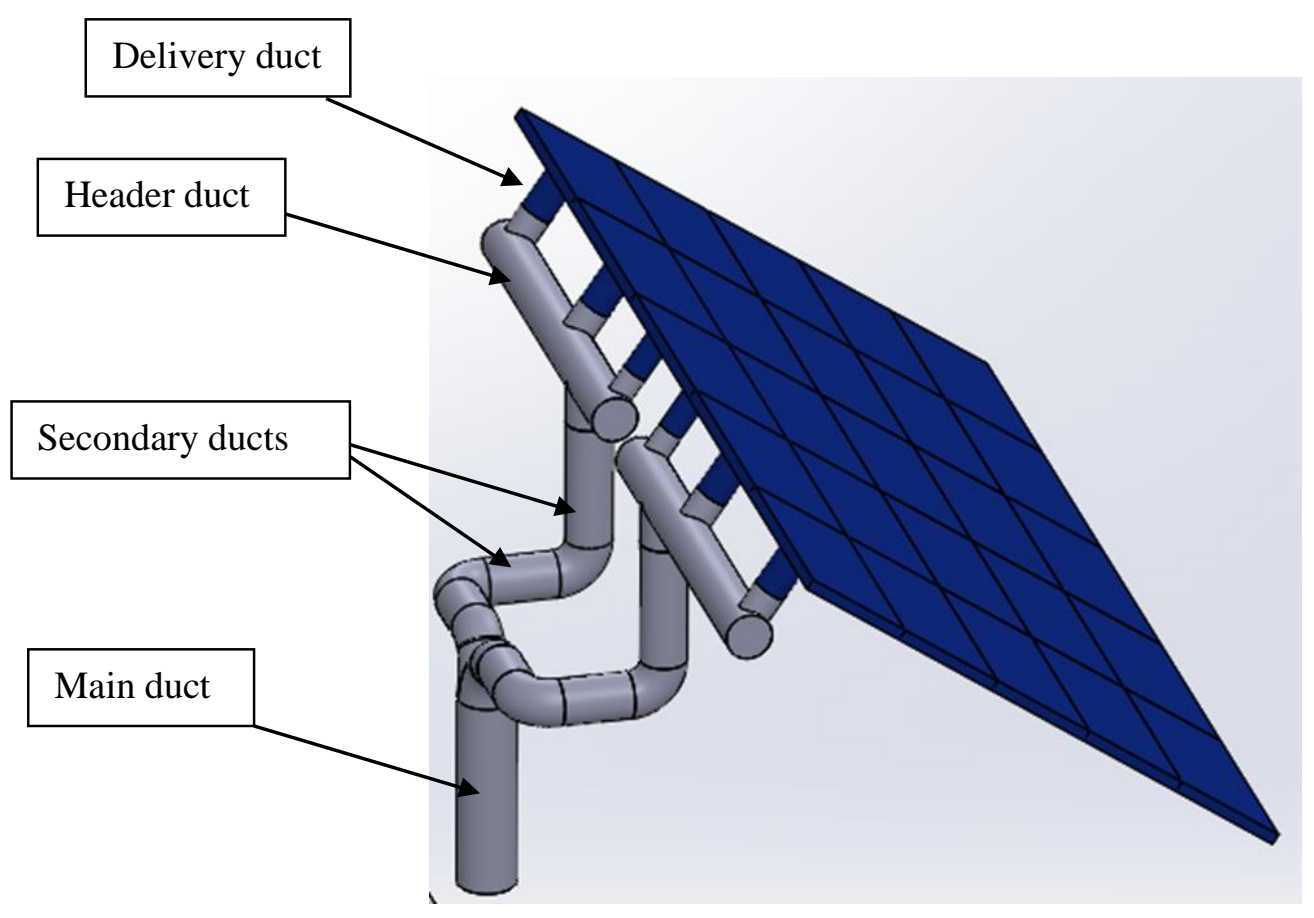

Figure 6-10: Duct system layout of the test hut facility 


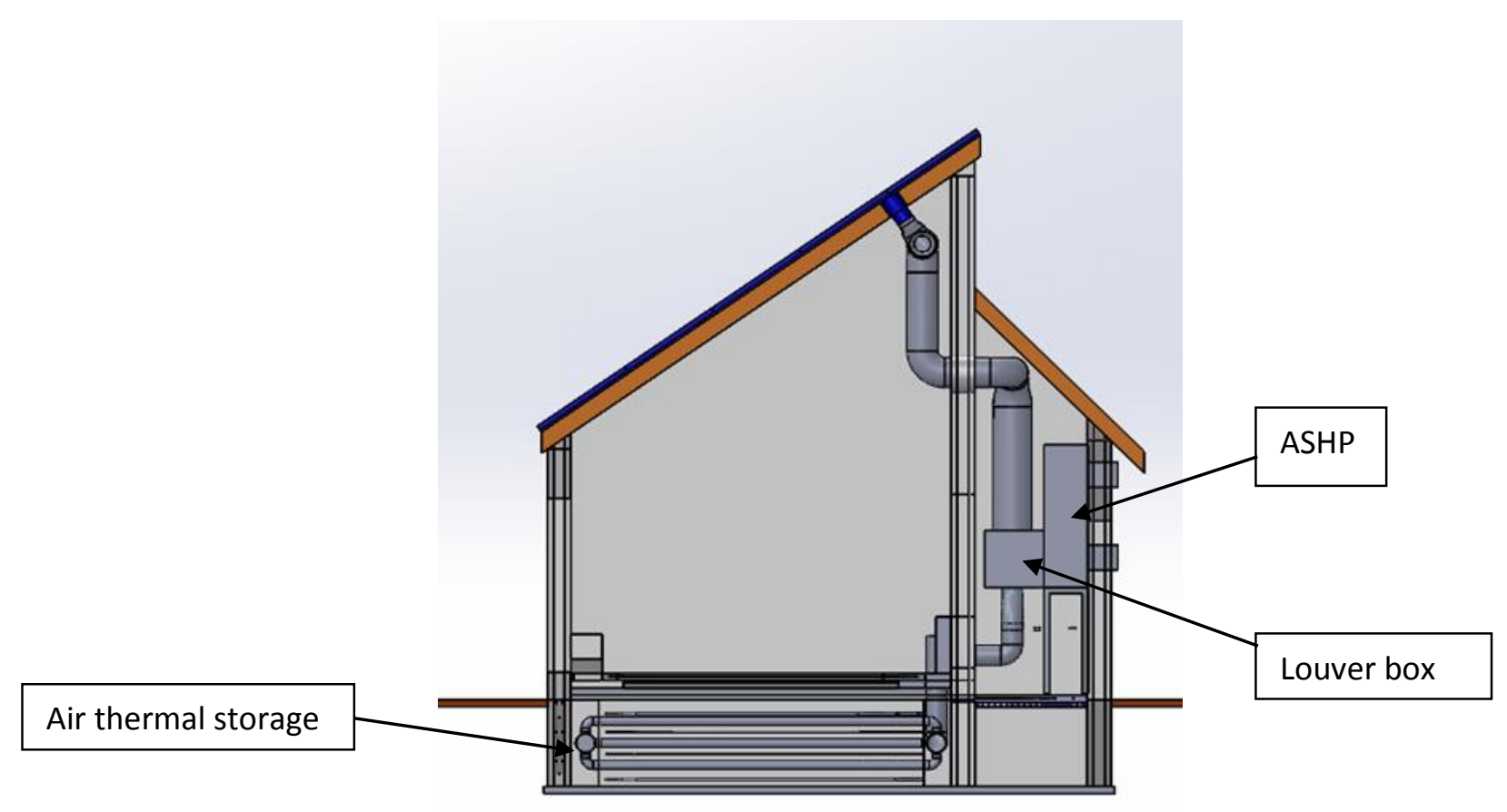

(a) side view

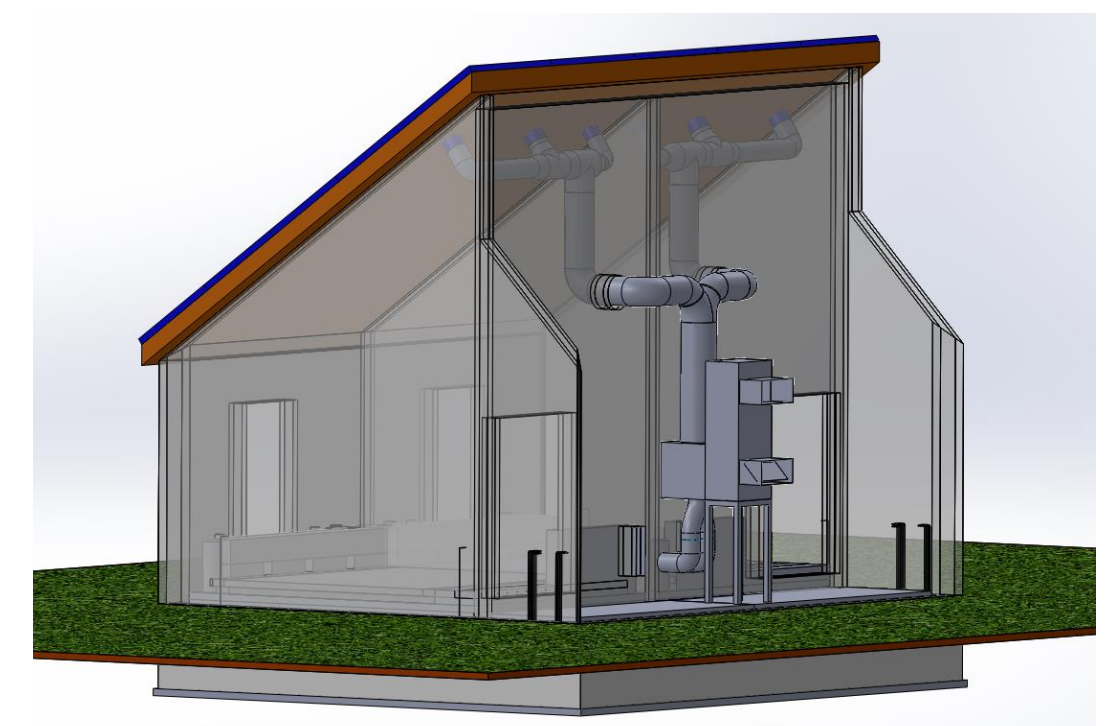

(b) 3D view

Figure 6-11: Illustration of test hut facility with BIPV/T system combined with ASHP and TES 
The recommended velocities range for residential houses in the main duct are 800-1200 FPM according to ASHRAE Standards (ASHARE Handbook, 1967) in order to avoid noise generation which is a main problem in duct system. A velocity value of 900 FPM $(4.6 \mathrm{~m} / \mathrm{s})$ was selected in the main duct for a total air flow rate of $2000 \mathrm{CFM}\left(0.944 \mathrm{~m}^{3} / \mathrm{s}\right)$. Table $6-2$ show the results from DUCT software for the layout of duct system in the test facility.

Table 6-2: Duct system size for coupling BIPV/T and ASHP for test hut facility

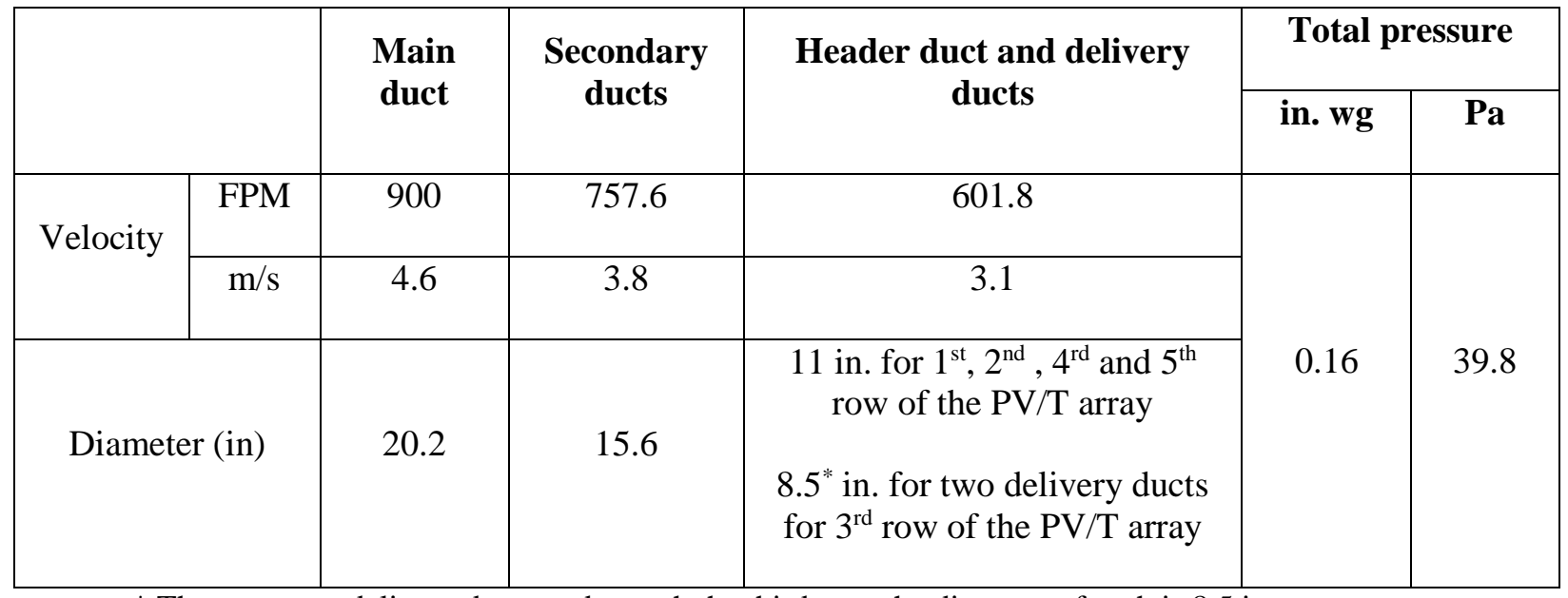

* There are two delivery ducts underneath the third row, the diameter of each is 8.5 in

\section{6-6 Summary and conclusion}

In this chapter, a detailed description of the full scale test hut facility was presented. It was designed and planned to be implemented at Toronto and Region Conservation Authority (TRCA)'s Kortright Centre to investigate the performance of combining solar systems and ASHP with different air thermal storage systems for net zero energy house applications. The building is designed to maximize the benefit of solar energy by storing the energy during the day and reuse it at night.

Such a complete integrated system requires building up a unique custom-designed heat pump system to work efficiently at night and day, providing heating and cooling. In this case, the operation conditions will not be affected by solar irradiance intensity. Therefore, the required duct system was developed with different operation modes. A complete TRNSYS model was developed for the test facility to estimate the hourly heating/cooling load. The results from TRNSYS model of the test facility were used to handle the test hut facility loads based on House A heating load. 
The fan power requirement to circulate air under the BIPV/T system duct and to deliver air to ASHP was conducted. It was found that for the maximum air flow rate for the heat pump (2000 CFM), the fan power consumption is low compared to electrical power generation from the $25 \mathrm{PV}$ panels, even for small duct depth. 


\section{Chapter 7: Conclusions and Future Works}

\subsection{Conclusions}

The objective of this research is modeling, simulation, and feasibility analysis of combining a building integrated photovoltaic thermal collector with an air source heat pump. Having preheated air from the BIPV/T system fed into the ASHP enhances the heat-pump COP. The literature review identified the necessity of investigation of connecting an air-based PV/T system with ASHP including air-based thermal energy storage. Having such an integrated system gives the flexibility to provide together heating and cooling. For better understanding, a numerical model was developed for air-based PV/T collector; the model was used to predict the thermal and electrical performance of the collector and to conduct a comprehensive analysis for different configurations (number of $\mathrm{PV} / \mathrm{T}$ systems in rows $\mathrm{N}_{R}$ and in series $\mathrm{N}_{S}$ ) and different design parameters. It was found that for the same total number of PV/T panels used in one array and same total mass flow rate, it is better to have $\mathrm{N}_{S}$ greater than $\mathrm{N}_{\mathrm{R}}$ in order to produce more thermal energy. This consideration has a minor effect on the total electricity production. A detailed model for transparent backing BIPV/T collector was also presented. The transferred heat through the nonpacking area as well as the heat transferred by convection and radiation enhance the thermal performance of the TBIPV/T system.

A TRNSYS model was developed to integrate photovoltaic/thermal collector (PV/T) in a roof and coupled with Air Source Heat Pump (ASHP) in an Archetype Sustainable House (ASH). The results showed that the air mass flow rate and the duct depth have a similar effect on the COP. In other words, low air mass flow rate and low duct depth enhance the COP. The arrangement with a large number of PV/T panels connected in series $\left(\mathrm{N}_{\mathrm{S}}\right)$ resulted in higher heat pump COP. It was found that COP could be increased from 2.74 to a maximum value of 3.45 without the use of diurnal thermal storage; corresponding to duct depth of $38 \mathrm{~mm}, \mathrm{~N}_{\mathrm{S}}=5$ and low row mass flow rate of $0.03 \mathrm{~kg} / \mathrm{s}$. The heat pump cumulative electricity consumption (day and night) for a typical heating season could be reduced by $20.2 \%$. When the analysis was based on sunny hours (ideal diurnal thermal energy storage system), the electricity consumption of the integrated heat pump with PV/T panels would be reduced by $52 \%$ and the predicted seasonal COP of the heat pump was 
5.98. The maximum achieved PV/T system efficiencies for the $\mathrm{N}_{S} \times \mathrm{N}_{\mathrm{R}}$ arrangements of $5 \times 3,5 \times 4$, and $5 \times 5$, with total mass flow rate of $1.2 \mathrm{~kg} / \mathrm{s}$ were $54 \%, 50 \%$, and $47 \%$, respectively.

The results from the simulation were used to estimate the saving in energy and cost as well as to predict the electricity related greenhouse gas (GHG) emission reduction potential from the PV panels. The results showed that annual GHG emission due to electricity demand by the ASHP was reduced by $225 \mathrm{~kg} \mathrm{CO}_{2} /$ year for combining ASHP with PV/T systems. The annual electricity cost credit from PV production based on Time-of-Use (TOU) and the reduction in electricity cost of the heat pump when connected with PV/T systems was calculated and compared with the cost of working the heat pump alone. The use of PV/T system and air source heat pump for heating purpose resulted in average monthly savings of \$24 and GHG emission credit of 1734.7 $\mathrm{kgCO}_{2} /$ year from renewable electricity generation.

The results shows that it cannot achieve high thermal energy production from a PV/T system and high outlet air temperature. However, for BIPV/T +ASHP, it is preferred to have high outlet air temperature and enough thermal energy to be absorbed from the outdoor coil of the heat pump. Therefore, the maximum air flow rate for the BIPV/T system should match the maximum air flow for the outdoor coil of the heat pump. The pressure drop inside the PV/T collector for a wide range of air flow rates and different duct depths was calculated. Based on the pressure drop calculations, the electricity consumption by a fan was calculated. The pressure drop for the connecting air duct from the BIPV/T to ASHP was also conducted. It was found that for an air flow rate around 2000 CFM, which is the maximum CFM for the custom-made ASHP for the test hut facility, the predicted fan energy was $195 \mathrm{kWh} /$ year corresponding to a duct depth of $1.5 \mathrm{in}$.

\subsection{Dissertation contribution}

The main contributions of the work presented in this dissertation are summarized below:

- The developed model of transparent backing air-based BIPV/T system was implemented as a new Type in TRNSYS, Type 211, a unique contribution for TRNSYS software. The non-packing area allows direct penetration for solar radiation; consequently, more heat is transferred to the flowing air along with the heat transferred by convection and radiation from air channel top and bottom surfaces. This enhances the thermal performance of the 
TBIPV/T system. Type 211 could be used by other users in large-scale applications of roof integrated transparent backing building integrated photovoltaic-thermal collector to investigate the benefits of coupling a PV/T collectors with other energy systems such as a heat pump and thermal energy storage. The proposed model can be used in another simulation software such as EnergyPlus (Vuong et al., 2015)

- A new integrated heat pump design for a test hut facility was presented with different operation modes in order to enable the whole system to work efficiently for all seasons.

- A TRNSYS BIPV/T type (Type 567) was modified based on a developed engineering model for PV/T collector. The modifications were made for Nusselt number and the incident angle modifier calculations. The modified Type was used to conduct sensitivity analysis of different parameters on thermal and electrical performance of BIPV/T system.

- The potential benefit and improvement in the heat pump performance, saving in electricity cost and reducing in GHG emission of direct coupling of BIPV/T+ASHP without the use of diurnal thermal storage, was investigated.

- As a team member, participated in the design of the test hut facility. A detailed model of the test hut facility in TRNSYS was developed to predict heating and cooling load of the building. A correlation between the test hut facility and House A was found since the design the mechanical system of the test hut is based on House A heating demand. This TRNSYS model can be used as a base to model different energy systems, which will be installed in the test hut facility.

\subsection{Future work/recommendations}

The following research areas are recommended as future work:

- The developed models (for both opaque and transparent backing PV/T collector) assumed identical heat transfer coefficients for the upper and lower surfaces of the BIPV/T duct. It is recommended to consider the asymmetric heating inside the PV/T duct. 
- Develop optimal operational control strategies for coupling BIPV/T +ASHP +TES. The challenges for coupling an air based PV/T system with an air source heat pump are related to the design of the control system, which should work optimally under all conditions. It is essential to develop proper control strategies, which enable the integrated system to work in an efficient way under different weather conditions, with a particular focus for combined space heating and cooling, and domestic hot water production.

- Conducting design optimization of the BIPV/T system suitable for different applications and climatic conditions.

- Performing air flow optimization which considers variable speed fan and variable capacity heat pump.

- Design optimization of overall thermal and electrical performance should be carried out to consider a PV/T system installation in a building.

- Due to the limited time and the construction of the test hut facility has not done yet (currently is under construction), it is recommended to investigate the performance of BIPV/T + ASHP under real weather conditions.

- A detailed performance analysis for coupling different thermal energy storages with (BIPV/T +ASHP) should be done to investigate the performance of the whole system. Thermal Energy Storage (TES) systems in residential buildings helps to manage the collected heat to avoid indoor space overheating and store thermal energy for later used when it is needed. This will improve the overall energy efficiency of the system. 


\section{Appendices}

\section{Appendix A: Definition of the Relations used in Energy Balance} Equations in Section 3.2

$$
\begin{aligned}
& \mathrm{U}_{\text {back }}=\frac{\mathrm{k}_{\text {back }}}{\mathrm{L}_{\text {back }}} \\
& \mathrm{U}_{\text {top }}=\left(\frac{\mathrm{L}_{\mathrm{g}}}{\mathrm{k}_{\mathrm{g}}}+\frac{1}{\mathrm{~h}_{\mathrm{c}}}\right)^{-1} \\
& \mathrm{~h}_{\mathrm{c}}=2.8+3 \mathrm{~V}_{\mathrm{w}} \\
& \mathrm{U}_{\text {ins }}=\frac{\mathrm{k}_{\text {ins }}}{\mathrm{L}_{\text {ins }}} \\
& \mathrm{A}=\mathrm{h}_{\mathrm{rs}}+\mathrm{U}_{\text {top }}+\mathrm{U}_{\text {back }} \\
& \mathrm{B}=\mathrm{h}_{\mathrm{rs}} \mathrm{T}_{\mathrm{s}}+\mathrm{U}_{\text {top }} \mathrm{T}_{\mathrm{amb}} \\
& \mathrm{F}=\mathrm{MH}+h_{r_{1-2}}^{2} \\
& \mathrm{H}=\mathrm{h}_{r_{1-2}}+\mathrm{h}_{\text {air }}+\mathrm{U}_{\text {ins }} \\
& \mathrm{K}_{1}=\frac{\mathrm{U}_{\text {back }}}{\mathrm{A}}\left(\tau_{\mathrm{g}} \alpha_{\mathrm{PV}} \mathrm{P}_{F}+\tau_{\mathrm{g}}\left(1-\mathrm{P}_{F}\right) \alpha_{\mathrm{T}}-\eta_{\text {panel }}\right) \mathrm{I}_{\mathrm{T}}+\frac{\mathrm{U}_{\text {back }} \mathrm{B}}{\mathrm{A}} \\
& \mathrm{M}=\frac{\mathrm{U}_{\text {back }}}{\mathrm{A}}-\mathrm{U}_{\text {back }}-\mathrm{h}_{r_{1-2}}-\mathrm{h}_{\text {air }} \\
& \mathrm{N}=\mathrm{MU}_{\text {ins }} \mathrm{T}_{3}-\mathrm{h}_{r_{1-2}} \mathrm{~K}_{1} \\
& \mathrm{~W}=\mathrm{Mh}_{\text {air }}-\mathrm{h}_{r_{1-2}} \mathrm{~h}_{\text {air }}
\end{aligned}
$$




\section{Appendix B: $\quad$ Type 211: Transparent Backing Building-Integrated Photovoltaic Thermal (TBIPV/T) System}

This TRNSYS type, Type 211, represents the model of transparent BIPV/T collector, which produces both electrical and thermal energy. The solar cells are sandwich between two transparent layers (glass-to-glass). The transparent area between the solar cells allowed solar radiation to pass directly to air flowing air inside the PV/T duct. The type is intended to operate with multi-zone detailed building model/Type (Type 56), which provides the temperature of the back surface of the collector $\left(\mathrm{T}_{3}\right)$.

Type 211 considers the changes of transmission, absorption, and reflection during the day as solar incident angle changes. Therefore, the user enters parameters of the cover material in addition to the absorptance of the solar cells.

Several assumptions were used in the model:

(1) Capacitance effects of system components are negligible except for flowing air

(2) the upper- and lower-channel heat transfer coefficients are identical

(3) Side losses are negligible

(4) The temperature variations are considered only in the flow direction, i.e., one dimension

(5) The cells are assumed to be operating at their maximum power point condition; implying that the voltage and current are not calculated by the model (this assumption is used in the opaque BIPV/T Type in TRNSYS). 


\section{Solving energy balance equations:}

Energy balance equation for the cover glass surface:

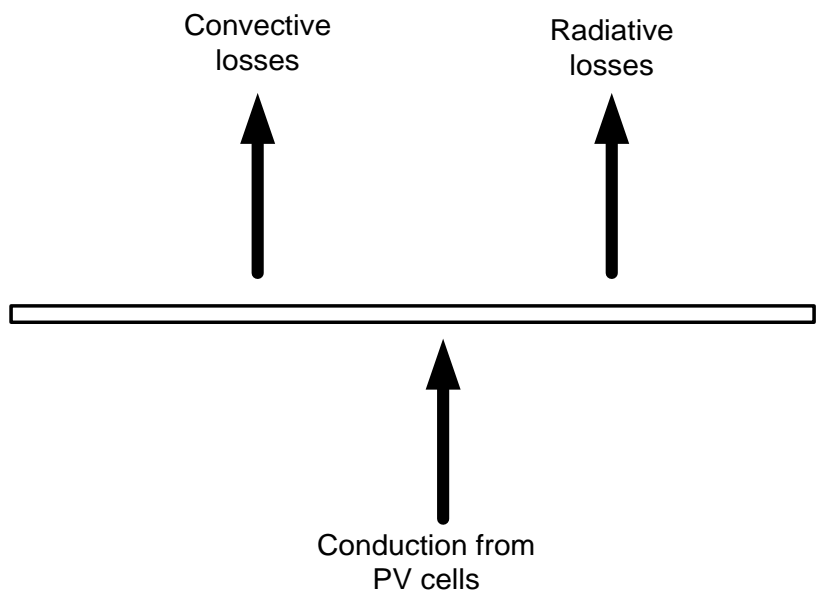

Figure B-1: Energy balance for the cover surface

$$
\frac{\mathrm{T}_{\mathrm{pv}}-\mathrm{T}_{\text {cover }}}{\mathrm{R}_{1}}=\mathrm{h}_{\mathrm{c}}\left(\mathrm{T}_{\text {cover }}-\mathrm{T}_{\mathrm{amb}}\right)+\mathrm{h}_{\mathrm{rs}}\left(\mathrm{T}_{\text {cover }}-\mathrm{T}_{\mathrm{s}}\right)
$$

Solving Equation (B-1) for $\mathrm{T}_{\text {cover: }}$ :

$$
\begin{aligned}
& \mathrm{T}_{\text {cover }}=\frac{\mathrm{T}_{\mathrm{pv}}}{\mathrm{F}}+\frac{\mathrm{R}_{1} \mathrm{~h}_{\mathrm{c}} \mathrm{T}_{\mathrm{amb}}}{\mathrm{F}}+\frac{\mathrm{R}_{1} \mathrm{~h}_{r s} \mathrm{~T}_{\mathrm{s}}}{\mathrm{F}} \\
& \text { Where } \quad F=\left(1+R_{1} h_{c}+R_{1} h_{r s}\right)
\end{aligned}
$$

Energy balance equation for the PV surface:

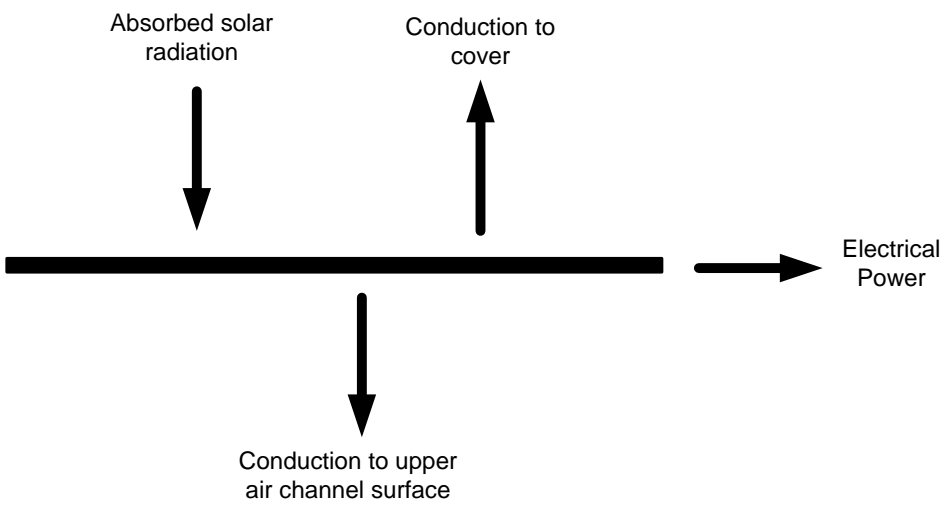

Figure B-2: Energy balance for the PV surface 


$$
\mathrm{S}=\frac{\mathrm{T}_{\mathrm{pv}}-\mathrm{T}_{\text {cover }}}{\mathrm{R}_{1}}+\frac{\mathrm{T}_{\mathrm{pv}}-\mathrm{T}_{1}}{\mathrm{R}_{2}}
$$

$\mathrm{S}$ is the absorbed solar radiation minus PV power production

$$
S=\tau_{g}(\theta) \alpha_{P V} I_{T} P_{F}-\eta_{\text {panel }} P_{F} \tau_{g}(\theta) I_{T}
$$

Solving Equation (B-4) for $T_{P V}$ :

$$
\begin{aligned}
& \mathrm{T}_{\mathrm{pv}}=\frac{\mathrm{S}}{\mathrm{G}}+\frac{\mathrm{h}_{\mathrm{c}} \mathrm{T}_{\mathrm{amb}}}{\mathrm{G} \mathrm{F}}+\frac{\mathrm{h}_{r s} \mathrm{~T}_{\mathrm{s}}}{\mathrm{G} \mathrm{F}}+\frac{\mathrm{T}_{1}}{\mathrm{G} \mathrm{R}_{2}} \\
& \text { Where } \quad G=\frac{1}{R_{1}}-\frac{1}{R_{1} F}+\frac{1}{R_{2}}
\end{aligned}
$$

Energy balance equation for the lower surface of air channel:

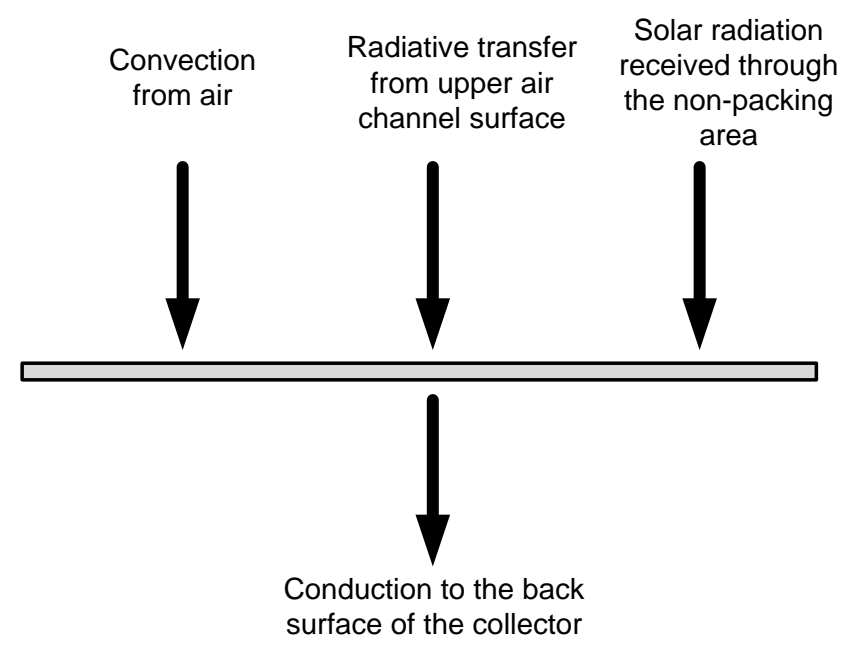

Figure B-3: Energy balance for the lower surface of air channel

$$
h_{\text {air }}\left(T_{\text {air }}-T_{2}\right)+h_{r_{1-2}}\left(T_{1}-T_{2}\right)+S_{2}=\frac{T_{2}-T_{3}}{R_{3}}
$$

Where $S_{2}$ is the solar radiation received by the lower surface of the air channel from the nonpacking area

$$
S_{2}=\alpha_{2}\left(1-P_{F}\right) \tau_{g}^{2}(\theta) I_{T}
$$

Solving for $T_{2}$ :

$$
T_{2}=\frac{h_{a i r} T_{a i r}}{j}+\frac{h_{r_{1-2}} T_{1}}{j}+\frac{S_{2}}{j}+\frac{T_{3}}{j R_{3}}
$$




$$
\text { Where } \quad j=\left(h_{\text {air }}+h_{r_{1-2}}+\frac{1}{R_{3}}\right)
$$

Energy balance equation for the upper surface of the air channel:

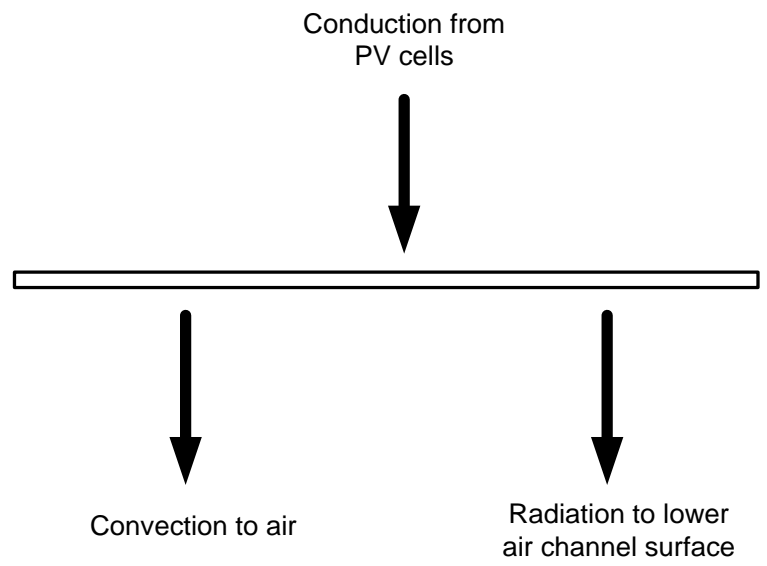

Figure B-4: Energy balance for the upper surface of air channel

$$
\frac{\mathrm{T}_{\mathrm{pv}}-\mathrm{T}_{1}}{\mathrm{R}_{2}}=\mathrm{h}_{\text {air }}\left(\mathrm{T}_{1}-\mathrm{T}_{\mathrm{air}}\right)+\mathrm{h}_{\mathrm{r}_{1-2}}\left(\mathrm{~T}_{1}-\mathrm{T}_{2}\right)
$$

Substitute $T_{P V}$ from Equation (B-6) and $T_{2}$ from Equation (B-10) in Equation (B-12), solving for $T_{1}$ :

$T_{1}=\frac{S}{m G}+\frac{h_{c} T_{a m b}}{m G F}+\frac{h_{r s} T_{S}}{m G F}+\frac{R_{2} h_{a i r} T_{a i r}}{m}+\frac{R_{2} h_{r_{1-2}} h_{a i r} T_{a i r}}{m j}+\frac{R_{2} h_{r_{1-2}} S_{2}}{m j}+\frac{R_{2} h_{r_{1-2}} T_{3}}{m j R_{3}}$

Where $m=1-\frac{1}{R_{2} G}+R_{2} h_{\text {air }}+R_{2} h_{r_{1-2}}-\frac{R_{2} h_{r_{1-2}}^{2}}{j}$ 
Energy balance equation for air flow inside the channel:

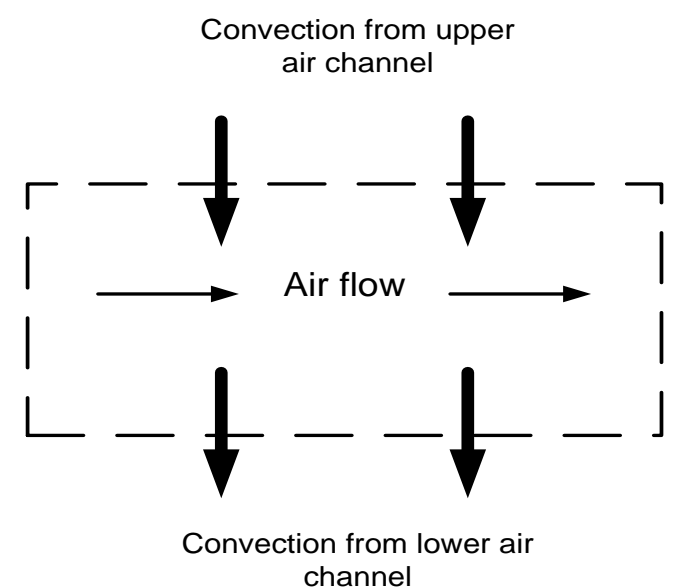

Figure B-5: Energy balance for air flowing inside the channel

$$
q=h_{\text {air }}\left(T_{1}-T_{\text {air }}\right)+h_{\text {air }}\left(T_{2}-T_{\text {air }}\right)
$$

Substitute $T_{1}$ from Equation (B-13) and $T_{2}$ from Equation (B-10) in Equation (B-15), solving for q :

$$
\begin{gathered}
q=T_{\text {air }}\left[-2 h_{\text {air }} T_{\text {air }}+\frac{h_{\text {air }}{ }^{2} R_{2}}{m}+\frac{2 h_{\text {air }}{ }^{2} R_{2} h_{r_{1-2}}}{m j}+\frac{h_{\text {air }}{ }^{2}}{j}+\frac{h_{\text {air }}{ }^{2}{h_{r_{1-2}}}^{2} R_{2}}{j^{2} m}+\frac{h_{\text {air }} S}{m G}+\frac{h_{\text {air }} h_{c} T_{\text {amb }}}{m G F}+\right. \\
\frac{h_{\text {air }} h_{r s} T_{S}}{m G F}+\frac{h_{\text {air }} R_{2} h_{r_{1-2}} T_{3}}{m j R_{3}}+\frac{h_{\text {air }} h_{r_{1-2}} S}{j m G}+\frac{h_{\text {air }} h_{r_{1-2}-2} h_{c} T_{\text {amb }}}{j m G F}+\frac{h_{\text {air }} h_{r_{1-2}} h_{r s} T_{S}}{j m G F}+\frac{h_{\text {air }} h_{r_{1-2}}{ }^{2} R_{2} T_{3}}{j^{2} m R_{3}}+ \\
\frac{h_{\text {air }} T_{3}}{j R_{3}}+\frac{h_{\text {air }} h_{r_{1-2}}{ }^{2} R_{2} S_{2}}{j^{2} m}+\frac{h_{\text {air }} S_{2}}{j}+\frac{h_{\text {air }} R_{2} h_{r_{1-2}} S_{2}}{m j}
\end{gathered}
$$

Comparing Equation (B-16) with Equation (4-7), the expression for the coefficients in Equation (4-7) are:

$$
\begin{gathered}
a=-2 h_{\text {air }} T_{\text {air }}+\frac{h_{\text {air }}{ }^{2} R_{2}}{m}+\frac{2 h_{\text {air }}{ }^{2} R_{2} h_{r_{1-2}}}{m j}+\frac{h_{\text {air }}{ }^{2}}{j}+\frac{h_{\text {air }}{ }^{2} h_{r_{1-2}}{ }^{2} R_{2}}{j^{2} m} \\
y=\frac{h_{\text {air }} S}{m G}+\frac{h_{\text {air }} h_{c} T_{\text {amb }}}{m G F}+\frac{h_{\text {air }} h_{r s} T_{s}}{m G F}+\frac{h_{\text {air }} R_{2} h_{r_{1-2}} T_{3}}{m j R_{3}}+\frac{h_{\text {air }} h_{r_{1-2}} S}{j m G}+\frac{h_{\text {air }} h_{r_{1-2}} h_{c} T_{\text {amb }}}{j m G F}+ \\
\frac{h_{\text {air }} h_{r_{1-2}} h_{r S} T_{S}}{j m G F}+\frac{h_{\text {air }} h_{r_{1-2}}{ }^{2} R_{2} T_{3}}{j^{2} m R_{3}}+\frac{h_{\text {air }} T_{3}}{j R_{3}}+\frac{h_{\text {air }} h_{r_{1-2}}{ }^{2} R_{2} S_{2}}{j^{2} m}+\frac{h_{\text {air }} S_{2}}{j}+\frac{h_{\text {air }} R_{2} h_{r_{1-2}} S_{2}}{m j}
\end{gathered}
$$




\section{Appendix C: $\quad$ FORTRAN Code of TRNSYS Type 211: Transparent backing BIPV/T}

SUBROUTINE TYPE211 (TIME,XIN,OUT,T,DTDT,PAR,INFO,ICNTRL,*)

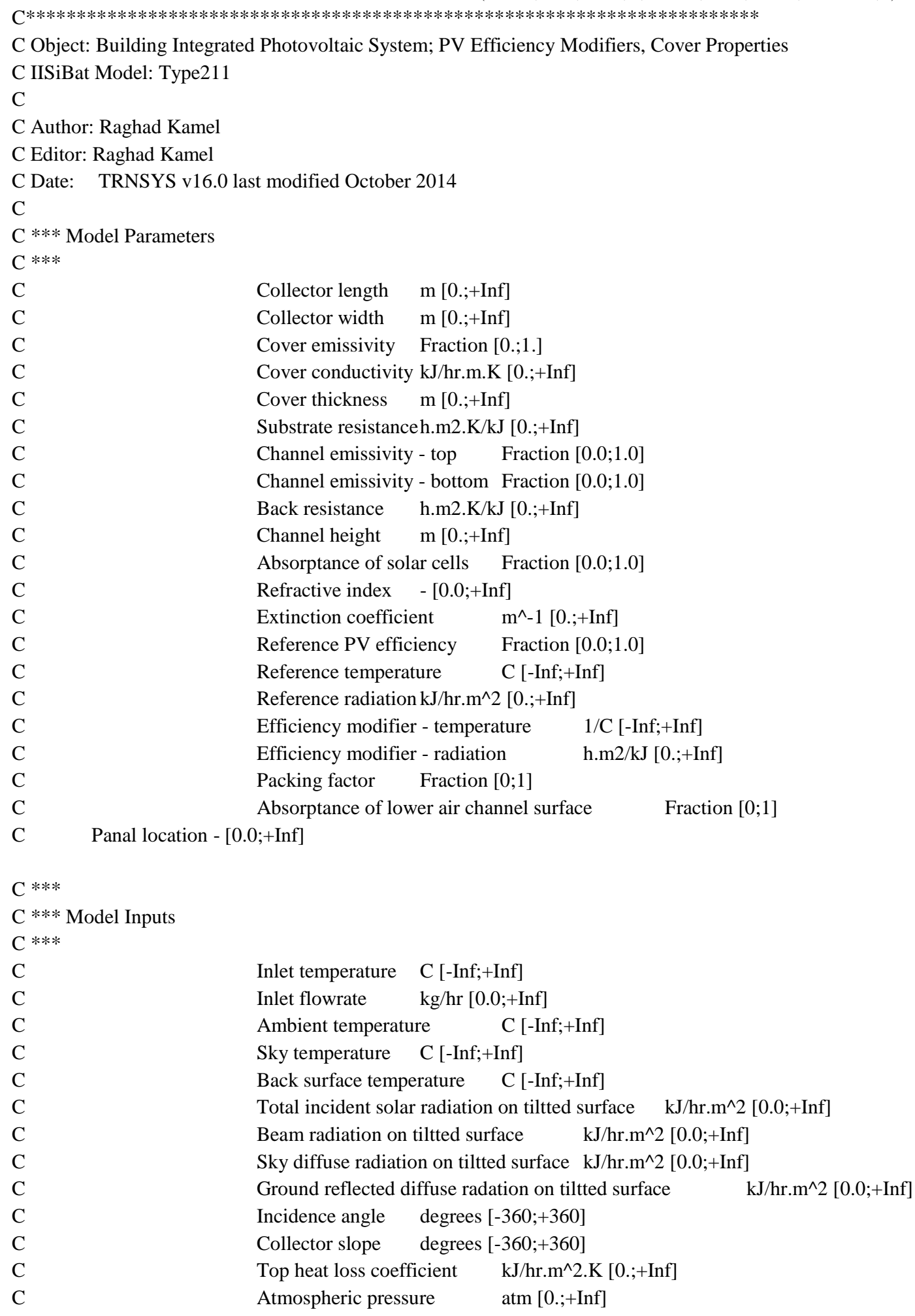




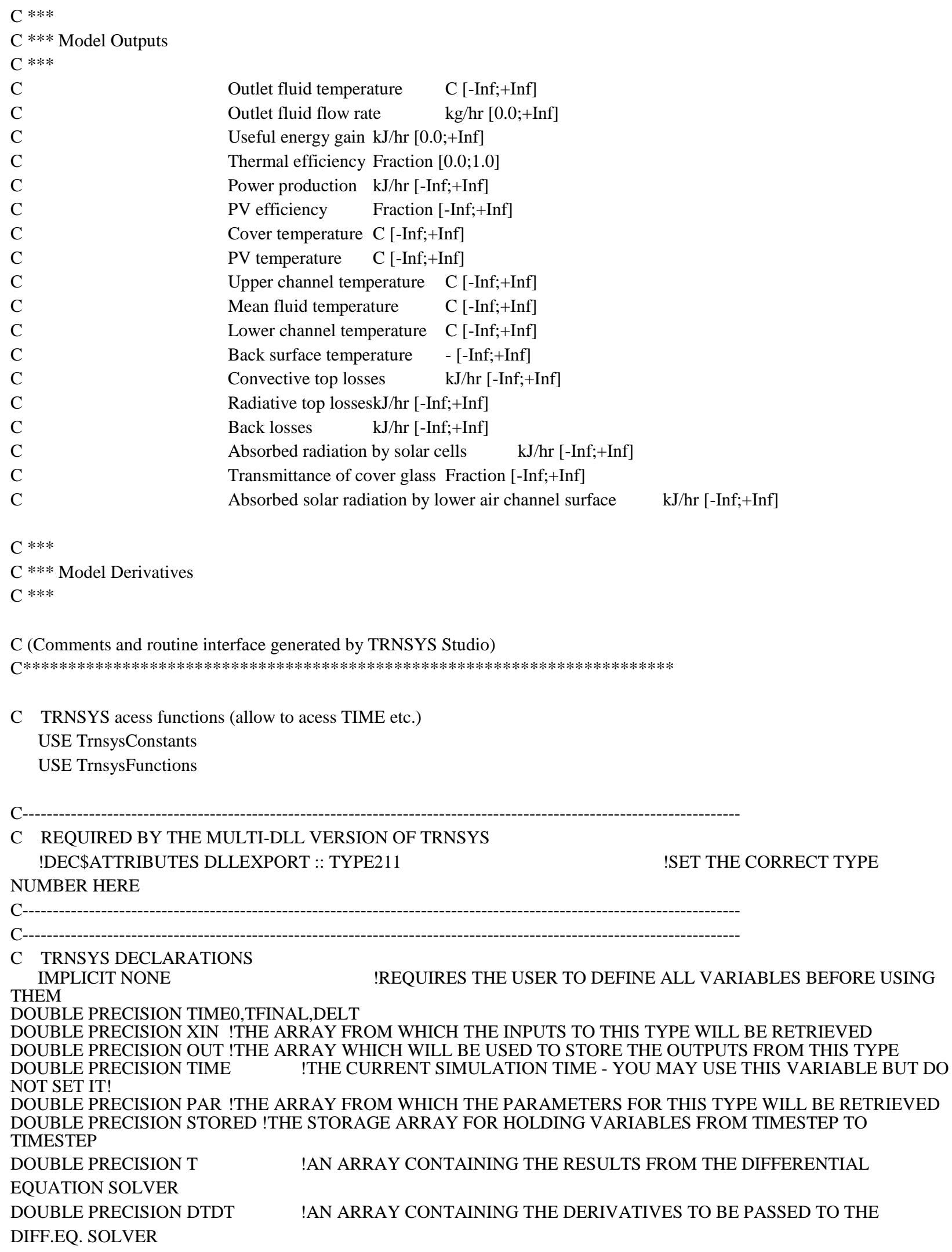


INTEGER *4 INFO(15)

TO AND FROM THIS TYPE

INTEGER $* 4$ NP,NI,NOUT,ND

PARAMETERS,INPUTS, OUTPUTS AND D

INTEGER $* 4$ NPAR,NIN,NDER
!THE INFO ARRAY STORES AND PASSES VALUABLE INFORMATION !VARIABLES FOR THE MAXIMUM NUMBER OF DERIVATIVES

!VARIABLES FOR THE CORRECT NUMBER OF

PARAMETERS,INPUTS,OUTPUTS AND DERIVATIVES INTEGER *4 IUNIT,ITYPE !THE UNIT NUMBER AND TYPE NUMBER FOR THIS COMPONENT INTEGER *4 ICNTRL

THE NEW SOLVER INTEGER *4 NSTORED ITHE NUMBER OF VARIABLES THAT WILL BE PASSED INTO AND

OUT OF STORAGE CHARACTER *3 OCHECK IAN ARRAY TO BE FILLED WITH THE CORRECT VARIABLE TYPES

FOR THE OUTPUTS CHARACTER *3 YCHECK IAN ARRAY TO BE FILLED WITH THE CORRECT VARIABLE TYPES FOR THE INPUTS
!AN ARRAY FOR HOLDING VALUES OF CONTROL FUNCTIONS WITH

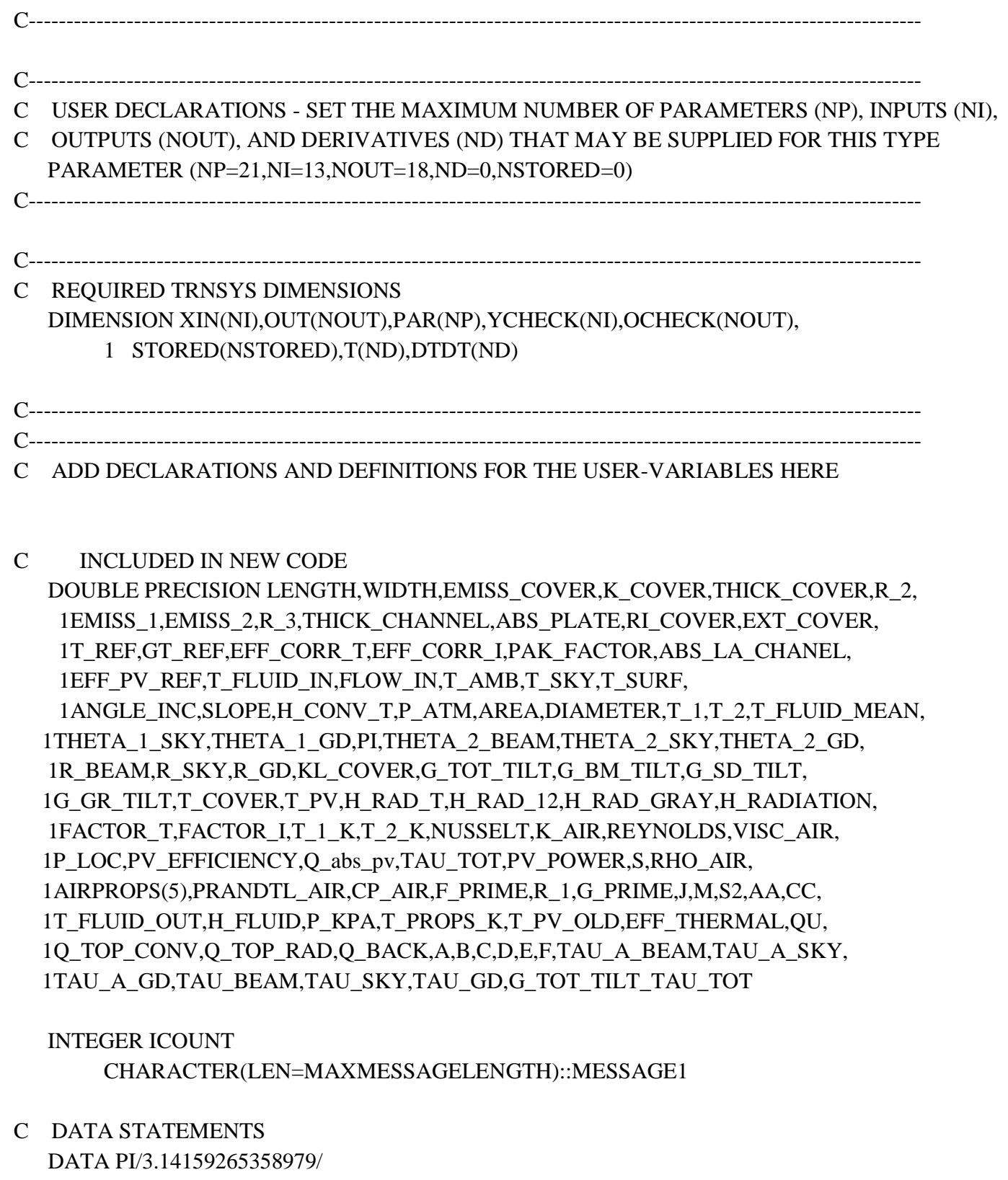


C GET GLOBAL TRNSYS SIMULATION VARIABLES

TIME0=getSimulationStartTime()

TFINAL=getSimulationStopTime()

DELT=getSimulationTimeStep()

C PARAMETERS symbols in program code

$\mathrm{C}$ Collector_length $=$ LENGTH

C Collector_width $=$ WIDTH

C Cover_emissivity $=$ EMISS_COVER

C Cover_conductivity $=$ K_COVER

$\mathrm{C}$ Cover_thickness $=$ THICK_COVER

C Substrate_resistance $=$ R_2

C Channel_emissivity__top $=$ EMISS_1

C Channel_emissivity__bottom $=$ EMISS_2

C Back_resistance $=\mathrm{R} \_3$

C Channel_height $=$ THICK_CHANNEL

C Absorptance_of_solar_cells $=$ ABS_PLATE

C Refractive_index $=$ RI_COVER

C Extinction_coefficient $=$ EXT_COVER

C Reference_PV_efficiency $=E F F \_P V \_R E F$

C Reference_temperature $=T$ _REF

C Reference_radiation $=$ GT_REF

$\mathrm{C}$ Efficiency_modifier_temperature $==E F F \_C O R R \_T$

$\mathrm{C}$ Efficiency_modifier__radiation $=$ EFF_CORR_I

C Packing_factor $=$ PAK_FACTOR

C Absorptance_of_lower_air_channel_surface = ABS_LA_CHANEL

C Panal location $=$ P_LOC

C INPUTS symbols in program code

C Inlet_temperature $=$ T_FLUID_IN

C Inlet_flowrate $=$ FLOW_IN

C Ambient_temperature $=$ T_AMB

C Sky_temperature $=$ T_SKY

C Back_surface_temperature $=T$ __SURF

C Total incident solar radiation on tiltted surface $=G_{-}$TOT_TILT

C Beam radiation on tiltted surface $=G_{-}$BM_TILT

C Sky diffuse radiation on tiltted surface $=G_{-}$SD_TILT

C Ground reflected diffuse radation on tiltted surface $=$ G_GR_TILT

C Incidence_angle $=$ ANGLE_INC

C Collector_slope $=$ SLOPE

C Top_heat_loss_coefficient $=\mathrm{H}_{-} \mathrm{CONV} \_\mathrm{T}$

C Atmospheric_pressure $=$ P_ATM

C-

C SET THE VERSION INFORMATION FOR TRNSYS

IF(INFO(7).EQ.-2) THEN

$\operatorname{INFO}(12)=16$

RETURN 1

ENDIF

C-

C DO ALL THE VERY LAST CALL OF THE SIMULATION MANIPULATIONS HERE 


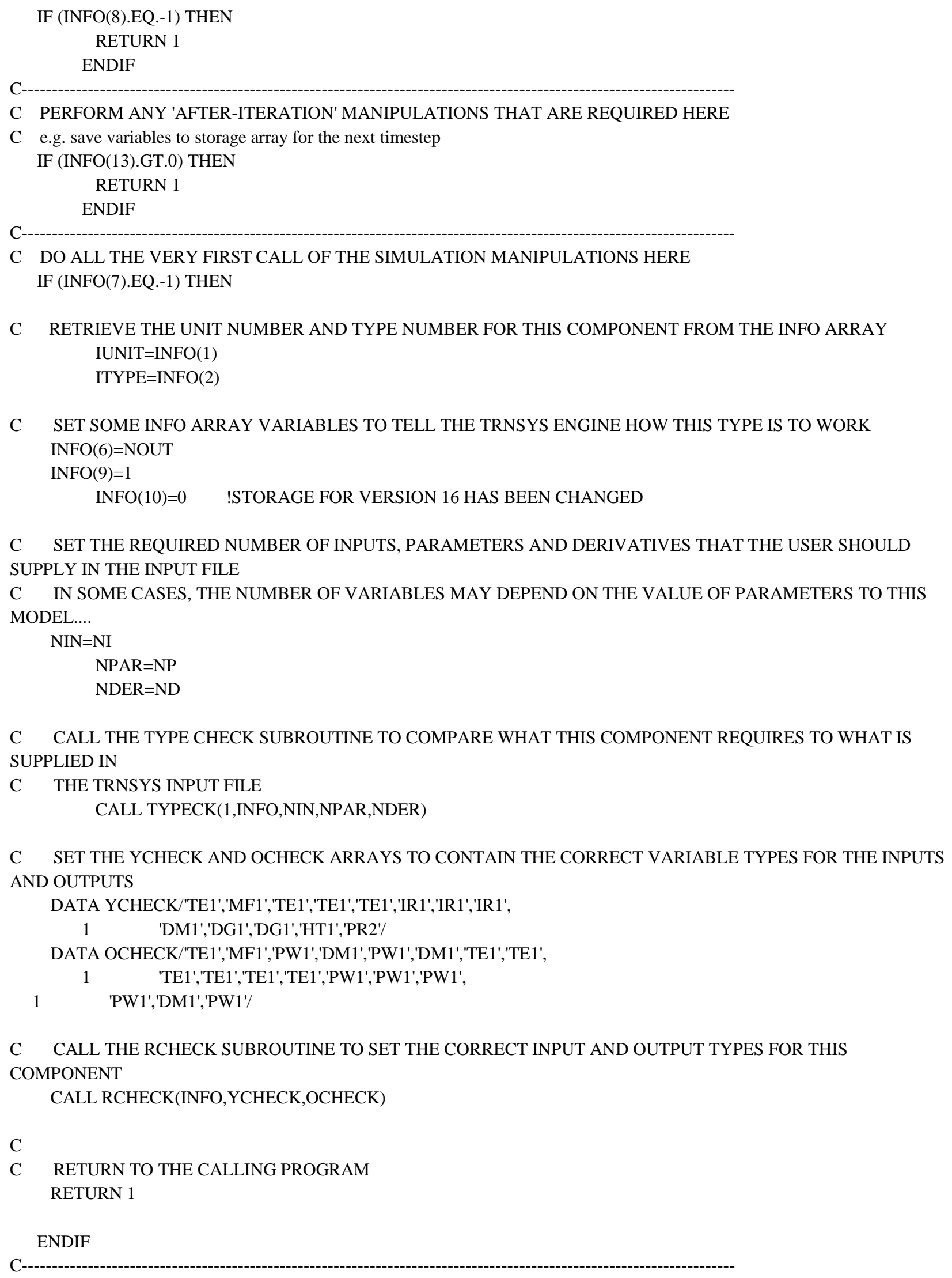


C DO ALL OF THE INITIAL TIMESTEP MANIPULATIONS HERE - THERE ARE NO ITERATIONS AT THE INTIAL TIME

IF (TIME .LT. (TIME0+DELT/2.D0)) THEN

C SET THE UNIT NUMBER FOR FUTURE CALLS

$\mathrm{IUNIT}=\mathrm{INFO}(1)$

$\operatorname{ITYPE}=\operatorname{INFO}(2)$

C READ IN THE VALUES OF THE PARAMETERS IN SEQUENTIAL ORDER

LENGTH=PAR(1)

WIDTH=PAR(2)

EMISS_COVER=PAR(3)

$\mathrm{K} \_\mathrm{COVER}=\mathrm{PAR}(4)$

THICK_COVER=PAR(5)

R_2=PAR(6)

EMISS_1=PAR(7)

EMISS_2=PAR(8)

R_3=PAR(9)

THICK_CHANNEL $=$ PAR $(10)$

ABS_PLATE $=$ PAR $(11)$

RI_COVER=PAR $(12)$

EXT_COVER=PAR(13)

EFF_PV_REF=PAR(14)

T_REF=PAR(15)

GT_REF=PAR(16)

EFF_CORR_T=PAR(17)

EFF_CORR_I=PAR(18)

PAK_FACTOR=PAR(19)

ABS_LA_CHANEL=PAR(20)

P_LOC $=$ PAR $(21)$

C CHECK THE PARAMETERS FOR PROBLEMS AND RETURN FROM THE SUBROUTINE IF AN ERROR IS FOUND

C IF(...) CALL TYPECK(-4,INFO,0,"BAD PARAMETER \#",0)

IF(LENGTH.LE.0.) CALL TYPECK(-4,INFO,0,1,0)

IF(WIDTH.LE.0.) CALL TYPECK(-4,INFO,0,2,0)

IF(EMISS_COVER.LT.0.) CALL TYPECK(-4,INFO,0,3,0)

IF(EMISS_COVER.GT.1.) CALL TYPECK(-4,INFO,0,3,0)

IF(K_COVER.LE.0.) CALL TYPECK(-4,INFO,0,4,0)

IF(THICK_COVER.LE.0.) CALL TYPECK(-4,INFO,0,5,0)

IF(R_2.LE.0.) CALL TYPECK(-4,INFO,0,6,0)

IF(EMISS_1.LT.0.) CALL TYPECK(-4,INFO,0,7,0)

IF(EMISS_1.GT.1.) CALL TYPECK(-4,INFO,0,7,0)

IF(EMISS_2.LT.0.) CALL TYPECK(-4,INFO,0,8,0)

IF(EMISS_2.GT.1.) CALL TYPECK(-4,INFO,0,8,0)

IF(R_3.LE.0.) CALL TYPECK(-4,INFO,0,9,0)

IF(THICK_CHANNEL.LT.0.) CALL TYPECK(-4,INFO,0,10,0)

IF(ABS_PLATE.LE.0.) CALL TYPECK(-4,INFO,0,11,0)

IF(ABS_PLATE.GT.1.) CALL TYPECK(-4,INFO,0,11,0)

IF(RI_COVER.LE.0.) CALL TYPECK(-4,INFO,0,12,0)

IF(EXT_COVER.LE.0.) CALL TYPECK(-4,INFO,0,13,0)

IF(EFF_PV_REF.LT.0.) CALL TYPECK(-4,INFO,0,14,0)

IF(EFF_PV_REF.GT.1.) CALL TYPECK(-4,INFO,0,14,0)

IF(GT_REF.LE.0.) CALL TYPECK(-4,INFO,0,16,0) 
IF(PAK_FACTOR.LE.0.) CALL TYPECK(-4,INFO,0,19,0)

IF(PAK_FACTOR.GT.1.) CALL TYPECK(-4,INFO,0,19,0)

IF(ABS_LA_CHANEL.LT.0.) CALL TYPECK(-4,INFO,0,20,0)

IF(ABS_LA_CHANEL.GT.1.) CALL TYPECK(-4,INFO,0,20,0)

IF(P_LOC.LT.0.) CALL TYPECK(-4,INFO,0,21,0)

IF(ERRORFOUND()) RETURN 1

$\mathrm{C}$

C

C

C

C

C

C

C

C

$\mathrm{C}$

C

C

C

C

C

C

C

$\mathrm{C}$

C

C

C RETURN TO THE CALLING PROGRAM

RETURN 1

ENDIF

Outlet fluid temperature

OUT $(1)=\mathrm{XIN}(1)$

Outlet fluid flow rate

$\operatorname{OUT}(2)=0$

Useful energy gain OUT $(3)=0$

Thermal efficiency

$$
\text { OUT(4) }=0.0
$$

Power production

$\operatorname{OUT}(5)=0$

PV efficiency

$\operatorname{OUT}(6)=0$

Cover temperature $=\mathrm{T} \_$COVER

$\operatorname{OUT}(7)=T \_A M B$

$\mathrm{PV}$ temperature $=\mathrm{T} \_\mathrm{PV}$

OUT $(8)=T \_A M B$

Upper channel temperature $=\mathrm{T}_{-} 1$ $\operatorname{OUT}(9)=X I N(1)$ $\operatorname{OUT}(10)=\mathrm{XIN}(1)$

Lower channel temperature $=T \_2$ $\operatorname{OUT}(11)=\mathrm{XIN}(1)$

Back surface temperature $=T \_3$ $\operatorname{OUT}(12)=\mathrm{XIN}(5)$

Convective top losses $\operatorname{OUT}(13)=0$

Radiative top losses $\operatorname{OUT}(14)=0$

Back losses

$\operatorname{OUT}(15)=0$

Absorbed radiation by solar cells OUT $(16)=0$

Transmittance of cover glass $\operatorname{OUT}(17)=0$

$\operatorname{OUT}(18)=0$

Mean fluid temperature $=$ T_FLUID_MEAN

Absorbed solar radiation by lower air channel surface

$\mathrm{C}-$

C *** ITS AN ITERATIVE CALL TO THIS COMPONENT ***

C- 
C RE-READ THE PARAMETERS IF ANOTHER UNIT OF THIS TYPE HAS BEEN CALLED IF(INFO(1).NE.IUNIT) THEN

C RESET THE UNIT NUMBER

$\mathrm{IUNIT}=\operatorname{INFO}(1)$

$\operatorname{ITYPE}=\operatorname{INFO}(2)$

C READ IN THE VALUES OF THE PARAMETERS IN SEQUENTIAL ORDER

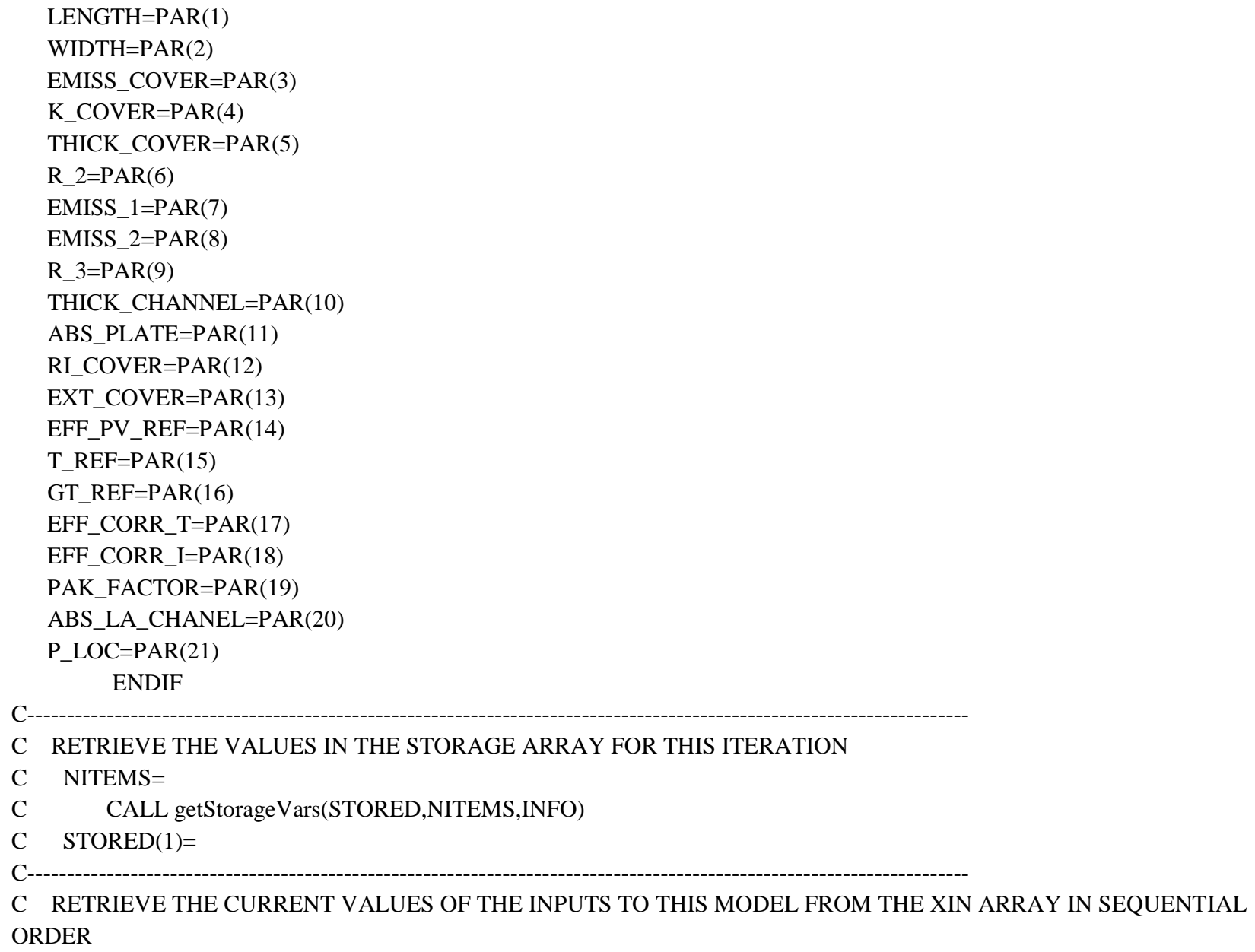


C CHECK THE INPUTS FOR PROBLEMS

C IF(...) CALL TYPECK(-3,INFO,'BAD INPUT \#',0,0)

IF(FLOW_IN.LT.0.) CALL TYPECK(-3,INFO, 2,0,0)

IF(G_TOT_TILT.LT.0.) CALL TYPECK(-3,INFO,6,0,0)

IF(G_BM_TILT.LT.0.) CALL TYPECK(-3,INFO,7,0,0)

IF(G_SD_TILT.LT.0.) CALL TYPECK(-3,INFO,8,0,0)

IF(G_GR_TILT.LT.0.) CALL TYPECK(-3,INFO,9,0,0)

IF(H_CONV_T.LT.0.) CALL TYPECK(-3,INFO,12,0,0)

IF(P_ATM.LE.0.) CALL TYPECK(-3,INFO,13,0,0)

IF(ERRORFOUND()) RETURN 1

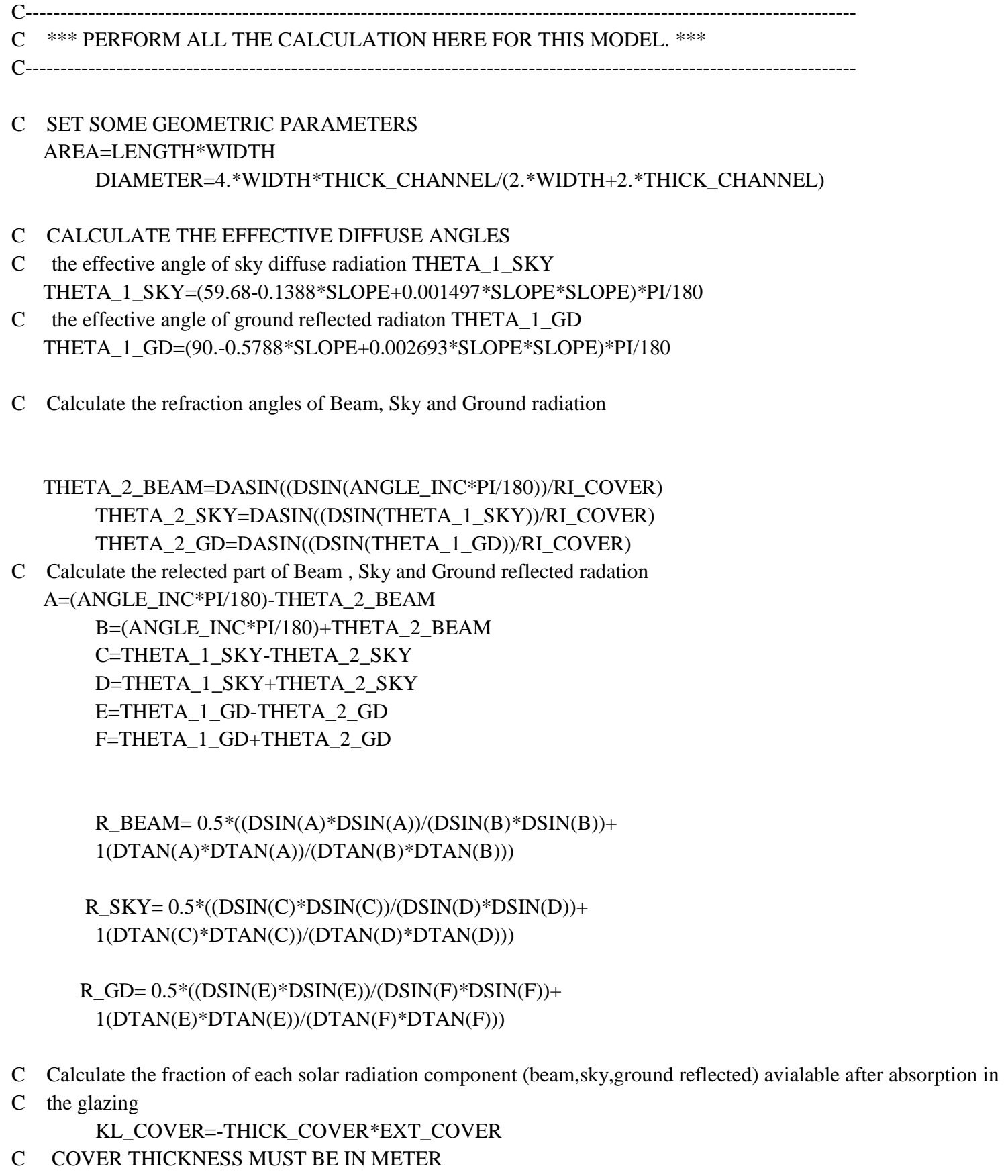

C Calculate the refraction angles of Beam, Sky and Ground radiation

THETA_2_BEAM=DASIN((DSIN(ANGLE_INC*PI/180))/RI_COVER) THETA_2_SKY=DASIN((DSIN(THETA_1_SKY))/RI_COVER)

C Calculate the relected part of Beam, Sky and Ground reflected radation $\mathrm{A}=(\mathrm{ANGLE} I \mathrm{INC} * \mathrm{PI} / 180)$-THETA_2_BEAM

C Calculate the fraction of each solar radiation component (beam,sky,ground reflected) avialable after absorption in

C COVER THICKNESS MUST BE IN METER 
TAU_A_BEAM=DEXP(KL_COVER/DCOS(THETA_2_BEAM))

TAU_A_SKY=DEXP(KL_COVER/DCOS(THETA_2_SKY))

TAU_A_GD=DEXP(KL_COVER/DCOS(THETA_2_GD))

$\mathrm{C}$ Calculate the transmitance of the glazing as a function of angle of incidence(Beam,Sky, ground reflected)

$\mathrm{C}$

TAU_BEAM=(TAU_A_BEAM*(1-R_BEAM $) * * 2.) /$

1 (1.-(TAU_A_BEAM*TAU_A_BEAM*R_BEAM*R_BEAM))

TAU_SKY=(TAU_A_SKY*(1-R_SKY)**2.)/(1.-(TAU_A_SKY*TAU_A_SKY*R_SKY* 1R_SKY))

TAU_GD=(TAU_A_GD*(1-R_GD)**2.)/(1.-(TAU_A_GD*TAU_A_GD*R_GD*R_GD))

$\mathrm{C}$ calculate the the total TAU of the cover glass

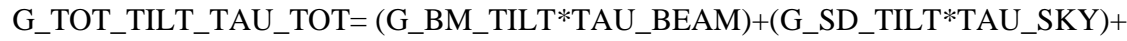

$1\left(\mathrm{G} \_\right.$GR_TILT*TAU_GD)

IF(G_TOT_TILT.GT.0.) THEN

TAU_TOT=G_TOT_TILT_TAU_TOT/G_TOT_TILT

ELSE

TAU_TOT $=0$.

ENDIF

C GUESS A COVER TEMPERATURE

T_COVER=(T_SKY+T_AMB $) / 2$.

C GUESS UPPER AND LOWER FLOW CHANNEL SURFACE TEMPERATURES

T_1=T_FLUID_IN

T_2=T_FLUID_IN

C GUESS A PV CELL TEMPERATURE

T_PV=(T_COVER+T_2)/2.

T_PV_OLD=T_PV

C GUESS A MEAN FLUID TEMPERATURE

T_FLUID_MEAN=T_FLUID_IN

C INITIALIZE THE COUNTER

$\mathrm{ICOUNT}=1$

C GET THE TOP SURFACE RADIATION COEFFICIENT

10 H_RAD_T=H_RADIATION(T_COVER,T_SKY,EMISS_COVER)

C GET THE INNER-CHANNEL RADIATION COEFFICIENT

H_RAD_12=H_RAD_GRAY(T_1,T_2,EMISS_1,EMISS_2)

C GET THE PV CELL EFFICIENCY

FACTOR_T $=1+E F F \_C O R R \_T *\left(T \_P V-T \_R E F\right)$

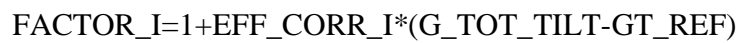

PV_EFFICIENCY=DMAX1(0.,(FACTOR_T*FACTOR_I*EFF_PV_REF))

$\mathrm{C}-$

C SET THE PROPERTIES OF THE AIR STREAM

T_PROPS_K=T_FLUID_MEAN+273.15

P_KPA=P_ATM*101.325

CALL AIRPROP(T_PROPS_K,P_KPA,AIRPROPS)

RHO_AIR=1./AIRPROPS $(1) \quad$ !KG/M3

VISC_AIR=AIRPROPS(2)*3600. !KG/M/HR 


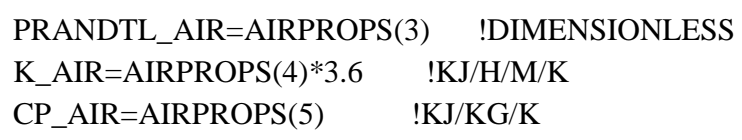

C CALCULATE THE REYNOLDS NUMBER

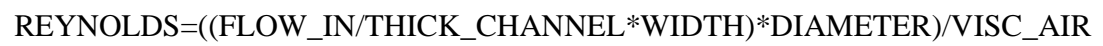

C CALCULATE THE FLUID CONVECTION COEFFICIENT IF(REYNOLDS.LE.0.) THEN

C CALL THE SUBROUTINE TO CALCULATE THE NUSSELT NUMBER FOR Natural CONVECTION INCLINED FLAT PLATES

T_1_K=T_1+273.15

T_2_K=T_2+273.15

CALL NUFLATPLATE(SLOPE,T_1_K,T_2_K,THICK_CHANNEL,P_KPA,NUSSELT)

C SET THE NATURAL CONVECTION HEAT TRANSFER COEFFICIENT

H_FLUID=NUSSELT*K_AIR/DIAMETER

ELSE IF(REYNOLDS.LE.2300.) THEN

C SET THE NUSSELT NUMBER (Laminar) NUSSELT $=4.9+(0.0606 *(($ REYNOLDS*PRANDTL_AIR*DIAMETER $) / L E N G T H) * * 1.2)$

$1 /(1+(0.0909 *(($ REYNOLDS $*$ PRANDTL_AIR *DIAMETER $) / L E N G T H) * * 0.7) *$

1PRANDTL_AIR**0.17)

C SET THE LAMINAR CONVECTION COEFFICIENT

H_FLUID=NUSSELT*K_AIR/DIAMETER

ELSE

C SET THE NUSSELT NUMBER (Turbulant) If(P_LOC.EQ.1)then

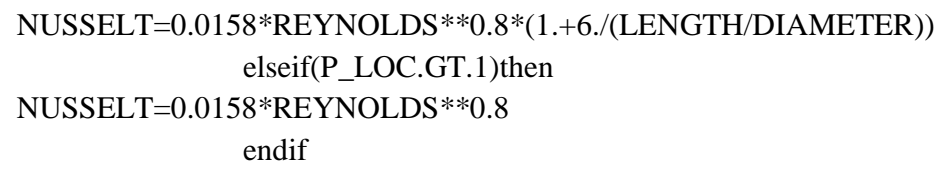

C SET THE TURBULENT CONVECTION COEFFICIENT

H_FLUID=NUSSELT*K_AIR/DIAMETER

ENDIF

C CALCULATE THE ABSORBED SOLAR RADIATION PER UNIT AREA

C Absorbed solar radiation by PV cells after pass the cover(per unit area) Q_abs_pv=TAU_TOT*ABS_PLATE*G_TOT_TILT*PAK_FACTOR

$\mathrm{C}$ electricity produced by solar cells (per unit area) PV_POWER=TAU_TOT*G_TOT_TILT*PAK_FACTOR*PV_EFFICIENCY

C Net absorbed solar radiation (per unit area) $\mathrm{S}=\mathrm{Q} \_$abs_pv-PV_POWER

C solar radiation recieved by lower surface of air channel from non packing area(per unit area) S2=ABS_LA_CHANEL*(1-PAK_FACTOR)*TAU_TOT*TAU_TOT*G_TOT_TILT 
C CALCULATE THE RESISTANCE DUE TO THE COVER MATERIAL

R_1=THICK_COVER/K_COVER

C SET SOME CONSTANTS WE'LL NEED

F_PRIME $=1 .+\mathrm{R} \_1 * \mathrm{H}_{-} \mathrm{CONV} \_\mathrm{T}+\mathrm{R} \_1 * \mathrm{H} \_\mathrm{RAD} \_\mathrm{T}$

G_PRIME $=1 . / R \_1+1 . / R \_2-1 . / R \_1 / F \_P R I M E$

$\mathrm{J}=\mathrm{H} \_\mathrm{RAD} \_12+\mathrm{H} \_$FLUID+1./R_3

$\mathrm{M}=1 .-1 . / \mathrm{R} \_2 / \mathrm{G} \_P R I M E+R \_2 * H \_F L U I D+R \_2 * H \_R A D \_12-R \_2 * H \_R A D \_12 *$

1 H_RAD_12/J

C REFORMULATE THE 5 ENERGY BALANCES TO FIND qu"=AA*T_fluid+CC

$\mathrm{AA}=-2$.*H_FLUID+H_FLUID*H_FLUID/J+H_FLUID*R_2*H_FLUID/M+H_FLUID*R_2

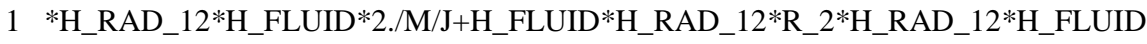
$1 / \mathrm{J} / \mathrm{M} / \mathrm{J}$

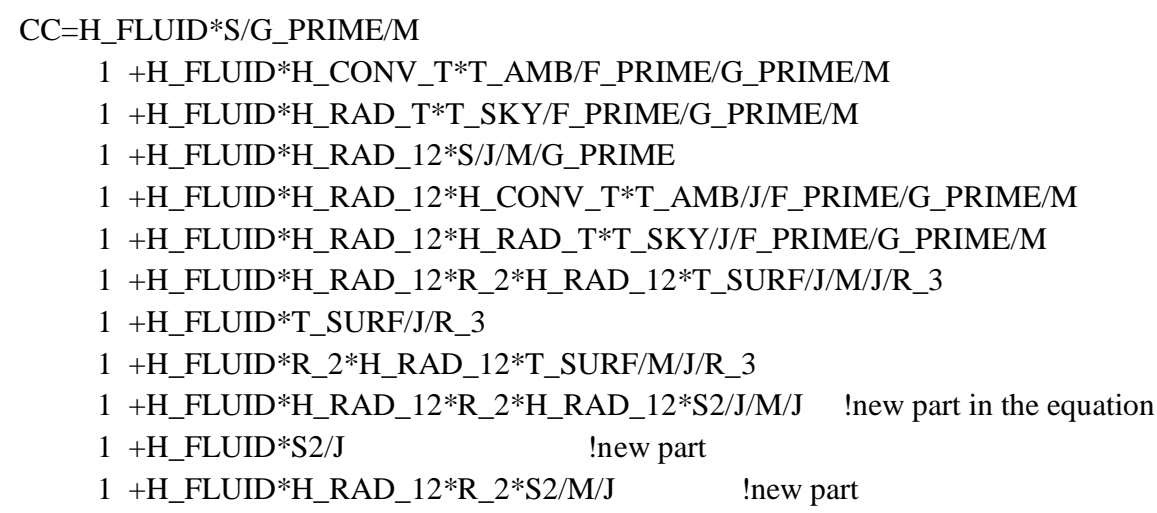

C SET THE CASE WITH NO FLOW

IF(FLOW_IN.LE.0.) THEN

C SET THE USEFUL ENERGY GAIN

$\mathrm{QU}=0$.

C SET THE MEAN FLUID TEMPERATURE FROM QU=AA(T)+CC

T_FLUID_MEAN=-CC/AA

C SET THE UPPER CHANNEL SURFACE TEMPERATURE

T_1=S/G_PRIME/M+H_CONV_T*T_AMB/F_PRIME/G_PRIME/M+H_RAD_T*T_SKY

1 /F_PRIME/G_PRIME/M+R_2*H_FLUID*T_FLUID_MEAN/M+R_2*H_RAD_12*

1 H_FLUID*T_FLUID_MEAN/M/J+R_2*H_RAD_12*T_SURF/M/J/R_3

$1+\mathrm{H} \_\mathrm{RAD} \_12 * \mathrm{R} \_2 * \mathrm{~S} 2 / \mathrm{M} / \mathrm{J} \quad$ !new part

C SET THE PV TEMPERATURE

T_PV=S/G_PRIME+H_CONV_T*T_AMB/F_PRIME/G_PRIME+H_RAD_T*T_SKY/

1 F_PRIME/G_PRIME+T_1/R_2/G_PRIME

C SET THE LOWER CHANNEL SURFACE TEMPERATURE

T_2=H_RAD_12*T_1/J+H_FLUID*T_FLUID_MEAN/J+T_SURF/J/R_3

$1+\mathrm{S} 2 / \mathrm{J} \quad$ !new part

C SET THE COVER TEMPERATURE

T_COVER=T_PV/F_PRIME+R_1 ${ }^{*} \mathrm{H}_{-} \mathrm{CONV}$ _T ${ }^{*} \mathrm{~T}$-AMB/F_PRIME+ 
1 R_1*H_RAD_T*T_SKY/F_PRIME

C SET THE FLUID OUTLET TEMPERATURE

T_FLUID_OUT=T_FLUID_MEAN

ELSE

C FIND THE FLUID OUTLET TEMPERATURE BY INTEGRATING THE FLUID DIFFERENTIAL EQUATION T_FLUID_OUT=(T_FLUID_IN+CC/AA)*DEXP(AA*AREA/FLOW_IN/CP_AIR)-

1 CC/AA

C FIND THE MEAN FLUID TEMPERATURE BY INTEGRATING THE LOCAL FLUID TEMPERATURE EQUATION T_FLUID_MEAN=(T_FLUID_IN+CC/AA)*DEXP(AA*AREA/FLOW_IN/CP_AIR $) /$

1 (AA*AREA/FLOW_IN/CP_AIR)-(T_FLUID_IN+CC/AA)/(AA*AREA/

1 FLOW_IN/CP_AIR)-CC/AA

C KNOWING THE INLET AND OUTLET TEMPERATURES CALCULATE THE COLLECTOR USEFUL ENERGY GAIN

$$
\text { QU=FLOW_IN*CP_AIR*(T_FLUID_OUT-T_FLUID_IN) }
$$

C SET THE UPPER CHANNEL SURFACE TEMPERATURE

T_1=S/G_PRIME/M+H_CONV_T*T_AMB/F_PRIME/G_PRIME/M+H_RAD_T*T_SKY

1 /F_PRIME/G_PRIME/M+R_2*H_FLUID*T_FLUID_MEAN/M+R_2*H_RAD_12*

1 H_FLUID*T_FLUID_MEAN/M/J+R_2*H_RAD_12*T_SURF/M/J/R_3

$1+\mathrm{H} \_\mathrm{RAD} \_12 * \mathrm{R} \_2 * \mathrm{~S} 2 / \mathrm{M} / \mathrm{J} \quad$ !new part

C SET THE PV TEMPERATURE

T_PV=S/G_PRIME+H_CONV_T*T_AMB/F_PRIME/G_PRIME+H_RAD_T*T_SKY/

1 F_PRIME/G_PRIME+T_1/R_2/G_PRIME

C SET THE LOWER CHANNEL SURFACE TEMPERATURE

T_2=H_RAD_12*T_1/J+H_FLUID*T_FLUID_MEAN/J+T_SURF/J/R_3

$1+\mathrm{S} 2 / \mathrm{J} \quad$ !new part

C SET THE COVER TEMPERATURE

T_COVER=T_PV/F_PRIME+R_1*H_CONV_T*T_AMB/F_PRIME+

1 R_1*H_RAD_T*T_SKY/F_PRIME

ENDIF

C CHECK TO SEE IF MORE ITERATIONS ARE REQUIRED

IF((DABS(T_PV_OLD-T_PV).GT.0.001).AND.

1 (ICOUNT.LT.1000)) THEN

T_PV_OLD=T_PV

ICOUNT=ICOUNT+1

GOTO 10

ENDIF

C CALCULATE THE THERMAL EFFICIENCY

IF(G_TOT_TILT.GT.0.) THEN

EFF_THERMAL=QU/AREA/G_TOT_TILT

ELSE

ENDIF

EFF_THERMAL=0.

C CALCULATE THE HEAT TRANSFERS

Q_TOP_CONV=H_CONV_T*AREA*(T_COVER-T_AMB) 


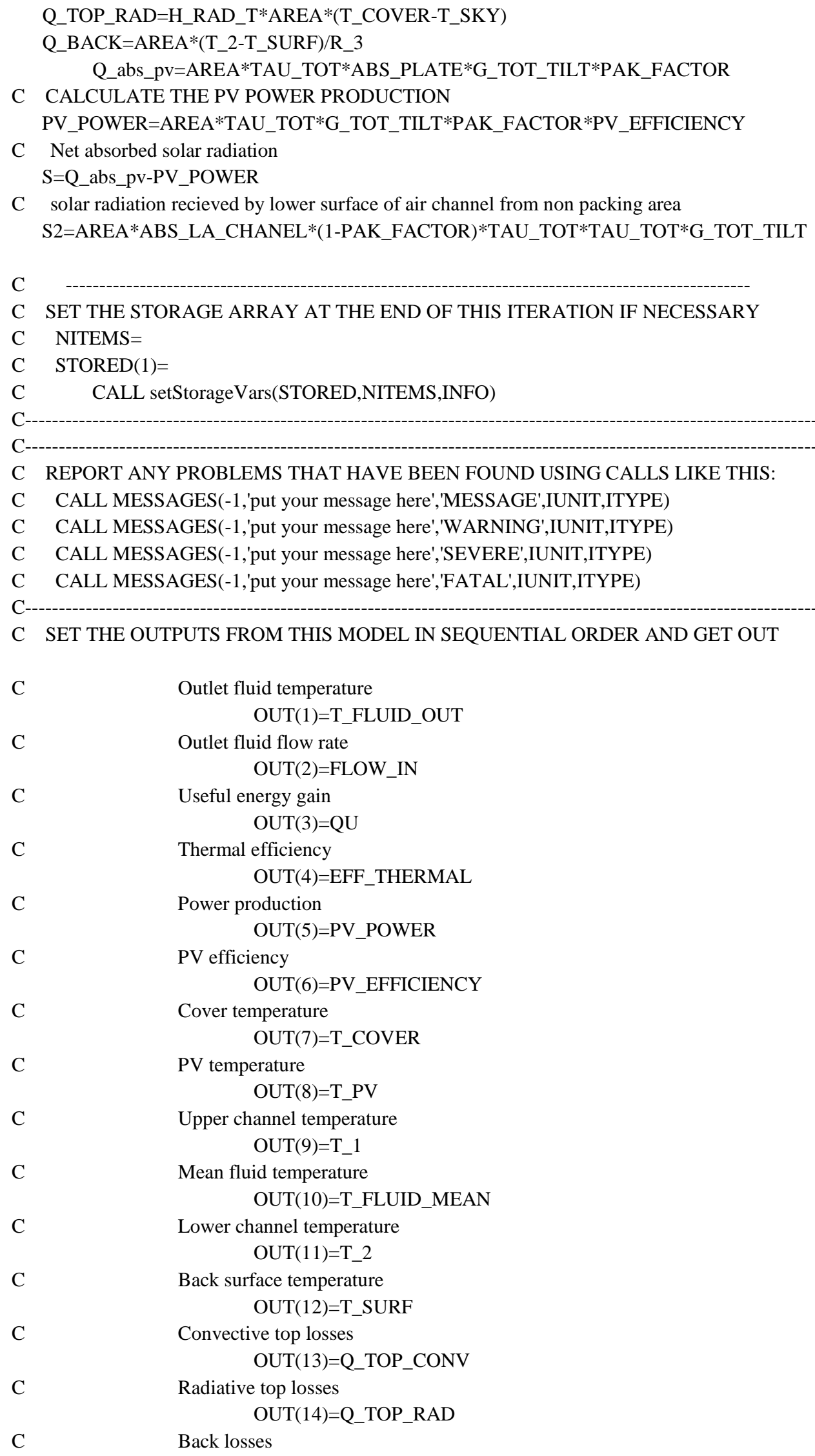


$\mathrm{C}$

$\mathrm{C}$

C

C KILL THE SIMULATION IF THE SYSTEM WAS UNABLE TO SOLVE IF(ICOUNT.GE.1000) THEN

CALL MESSAGES(-1,MESSAGE1,'FATAL',IUNIT,ITYPE) ENDIF

$\mathrm{C}-$

C EVERYTHING IS DONE - RETURN FROM THIS SUBROUTINE AND MOVE ON RETURN 1

END

OUT(15)=Q_BACK

Absorbed radiation by solar cells

OUT(16)=Q_abs_pv

Transmittance of cover glass

OUT(17)=TAU_TOT

Absorbed solar radiation by lower air channel surface

$\operatorname{OUT}(18)=\mathrm{S} 2$

$\mathrm{C}-$ 


\section{Appendix D: $\quad$ Engineering Drawing of the Test Hut Facility at TRCA*}

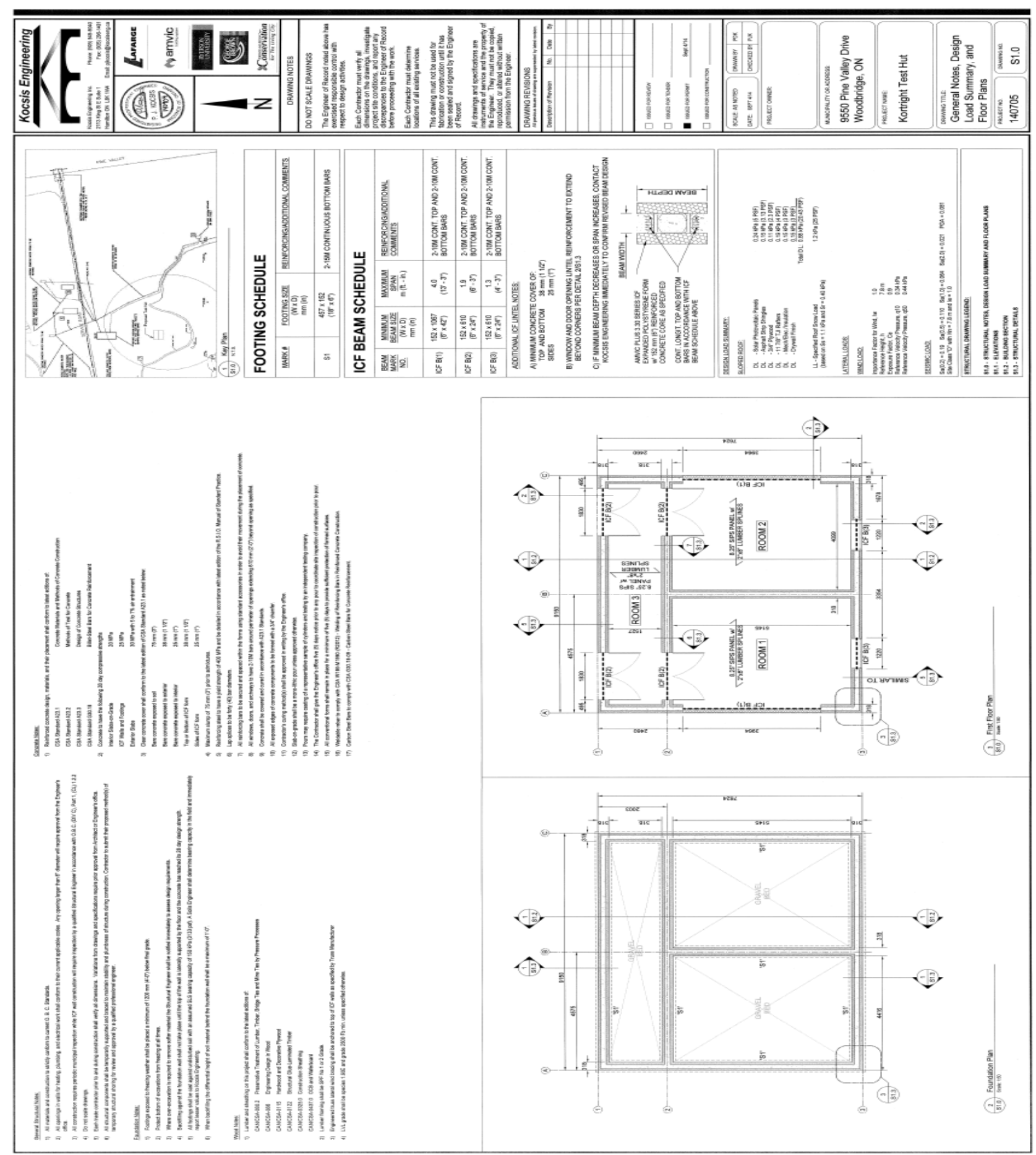

*The engineering drawing was performed by George Brown College 

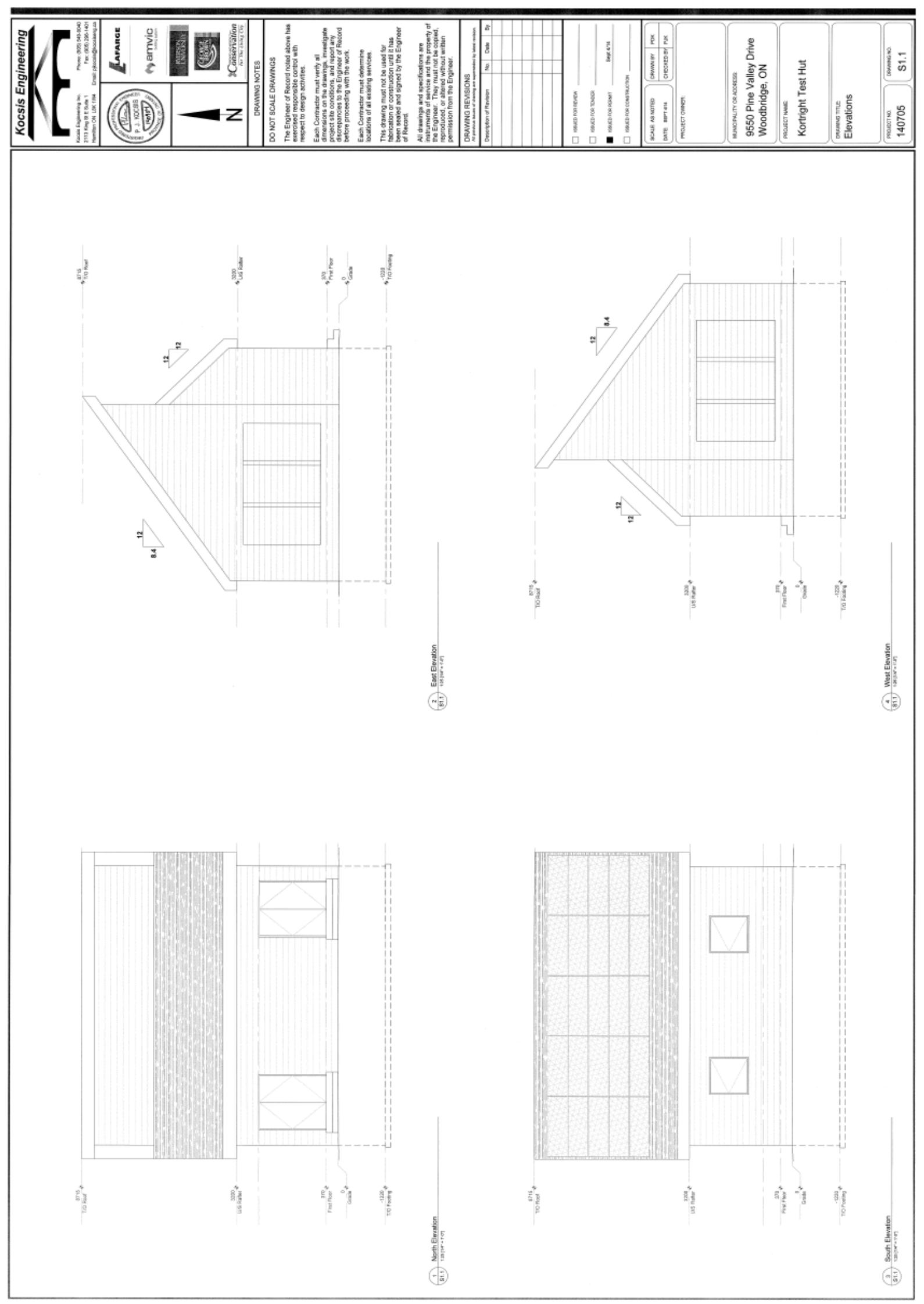

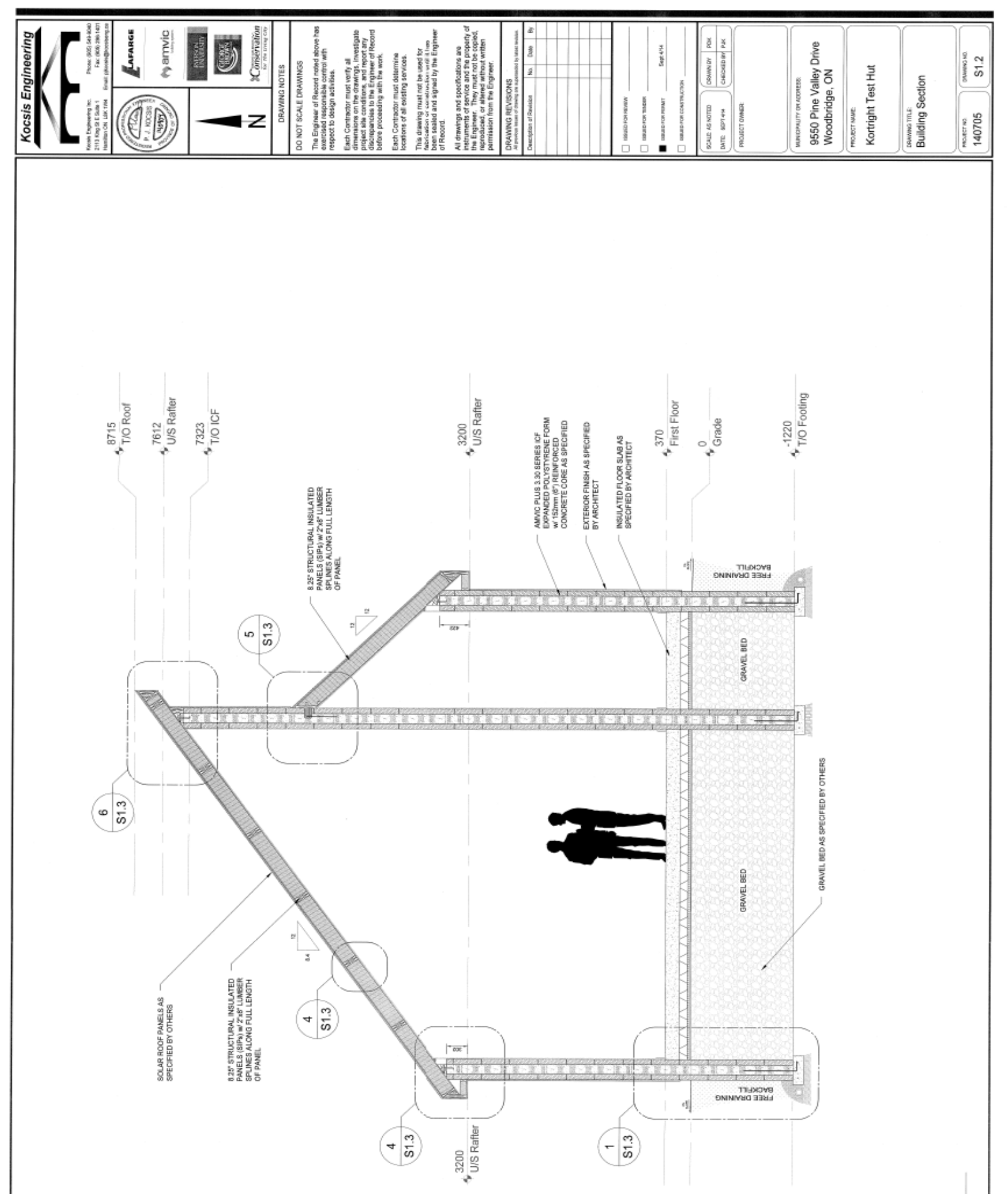

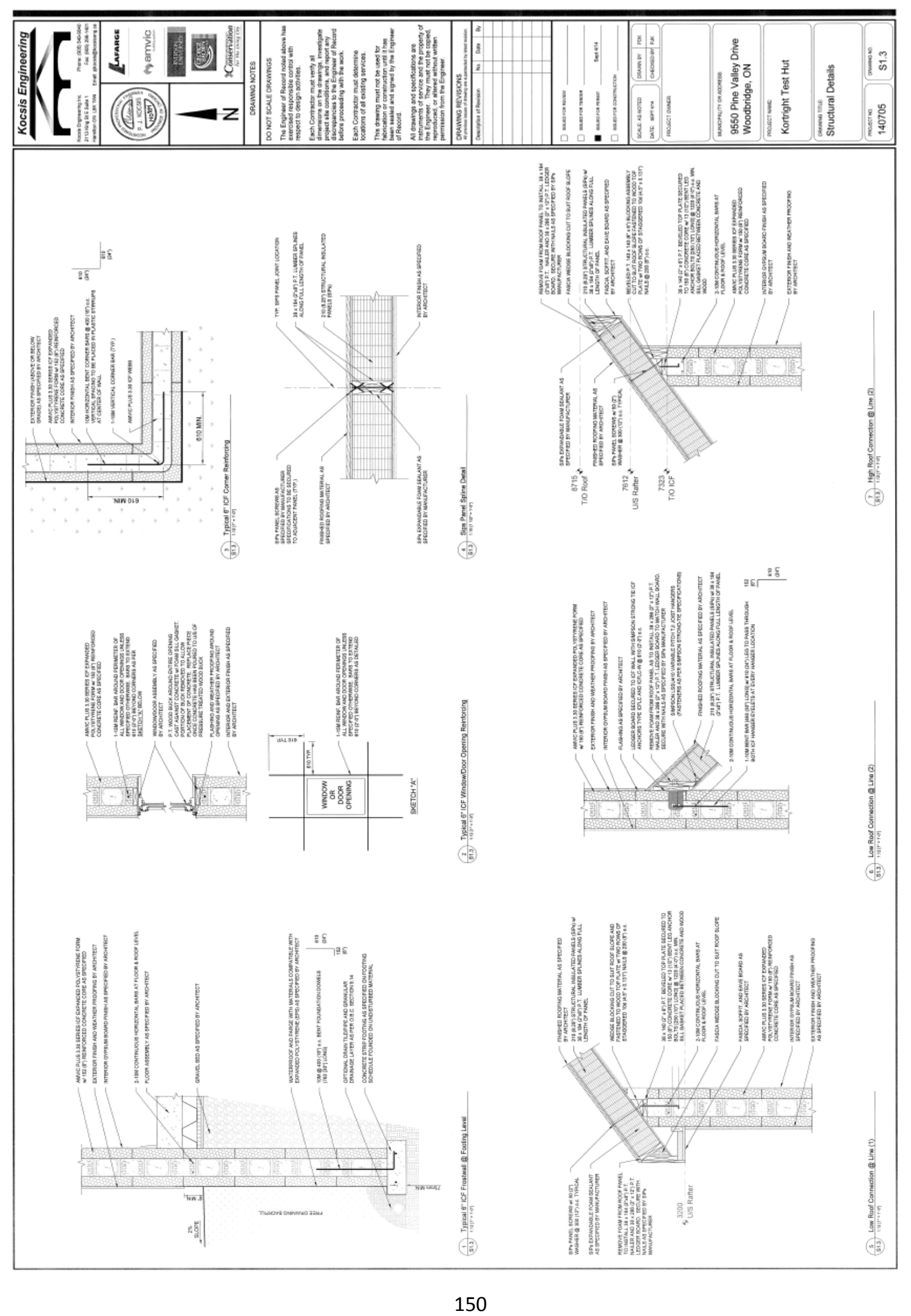
Appendix E: Additional Pictures for the Test Hut Facility
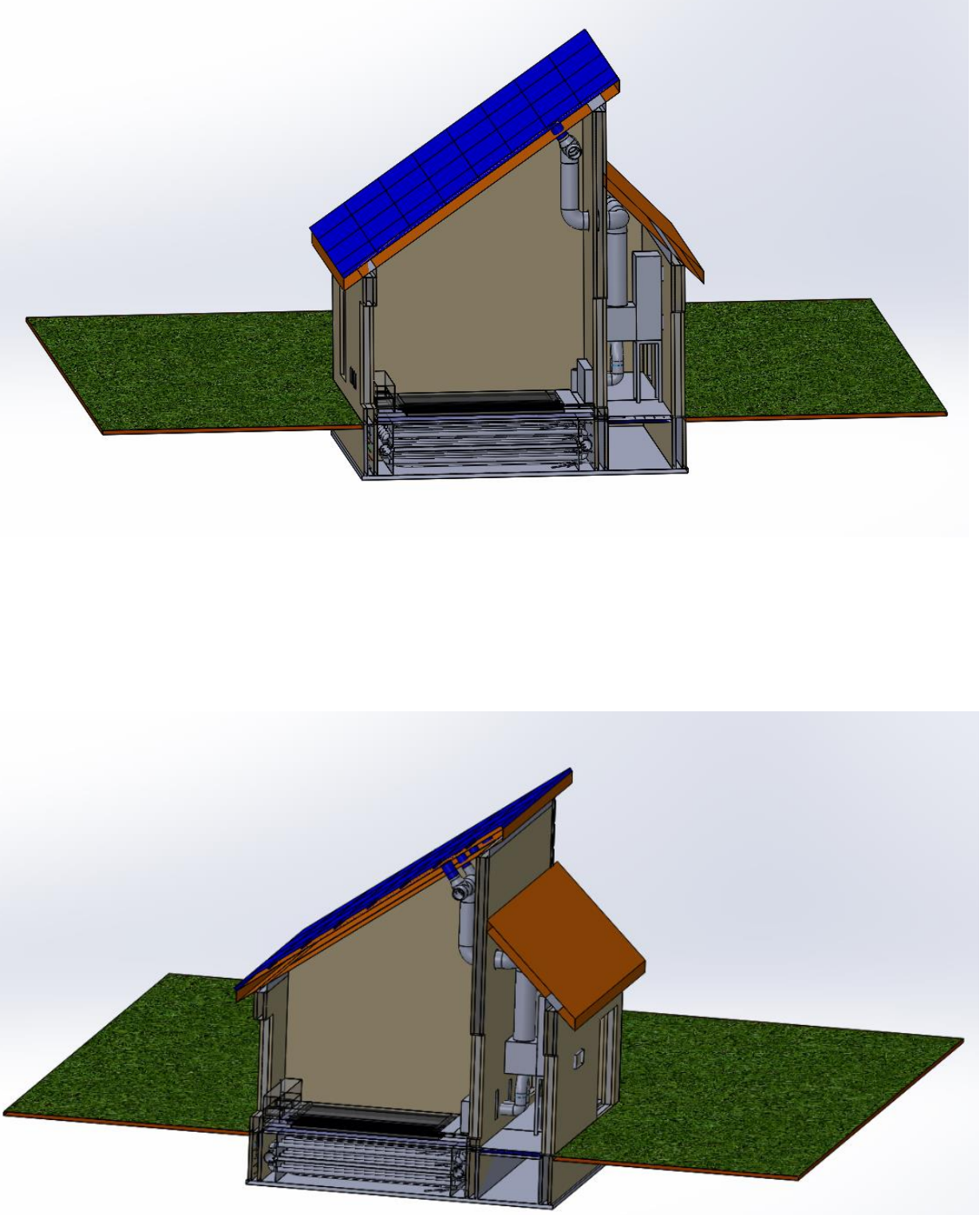

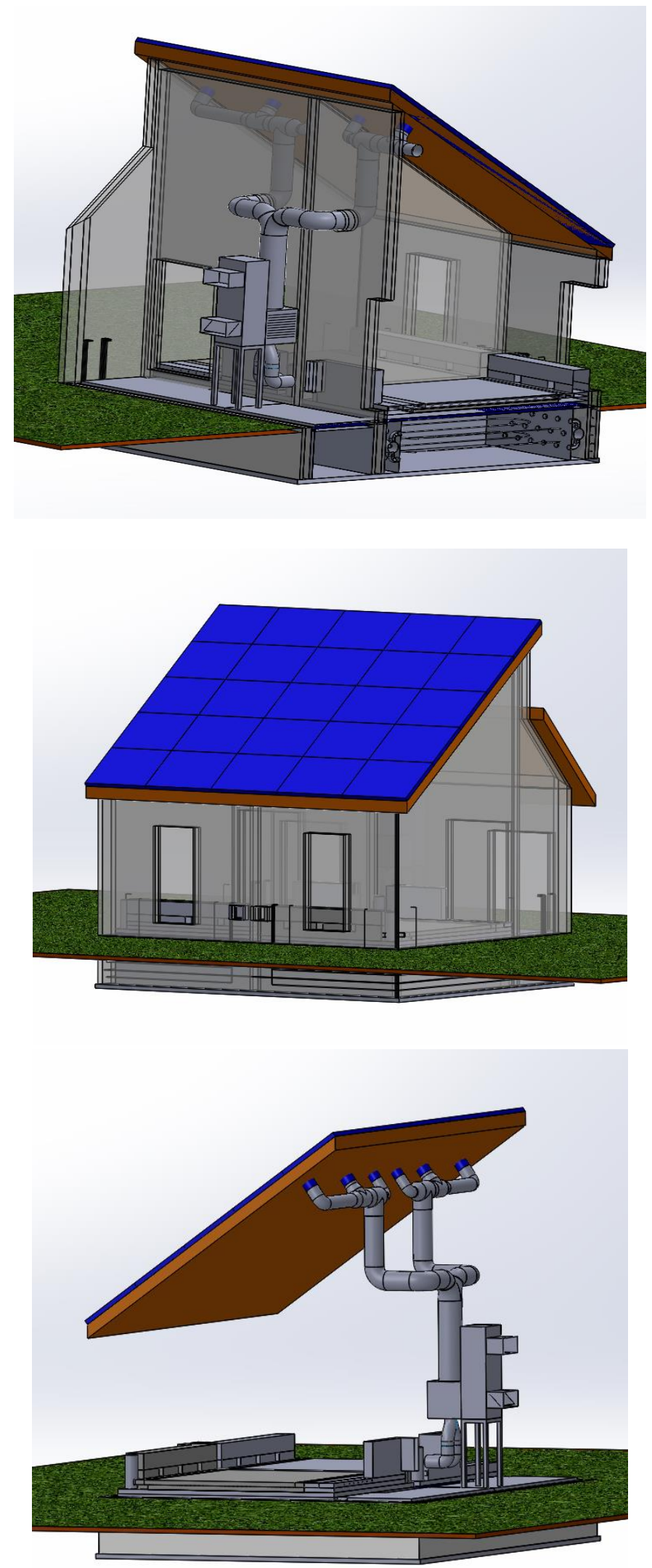


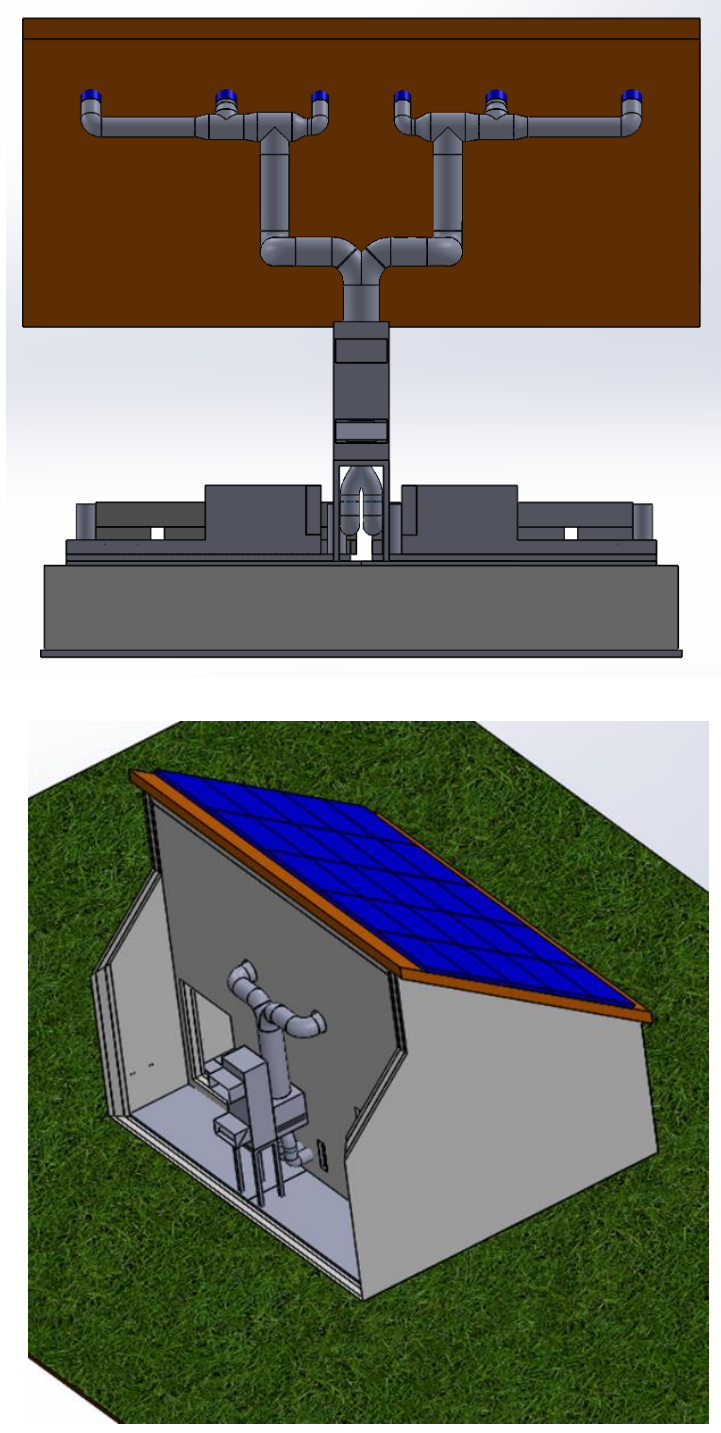




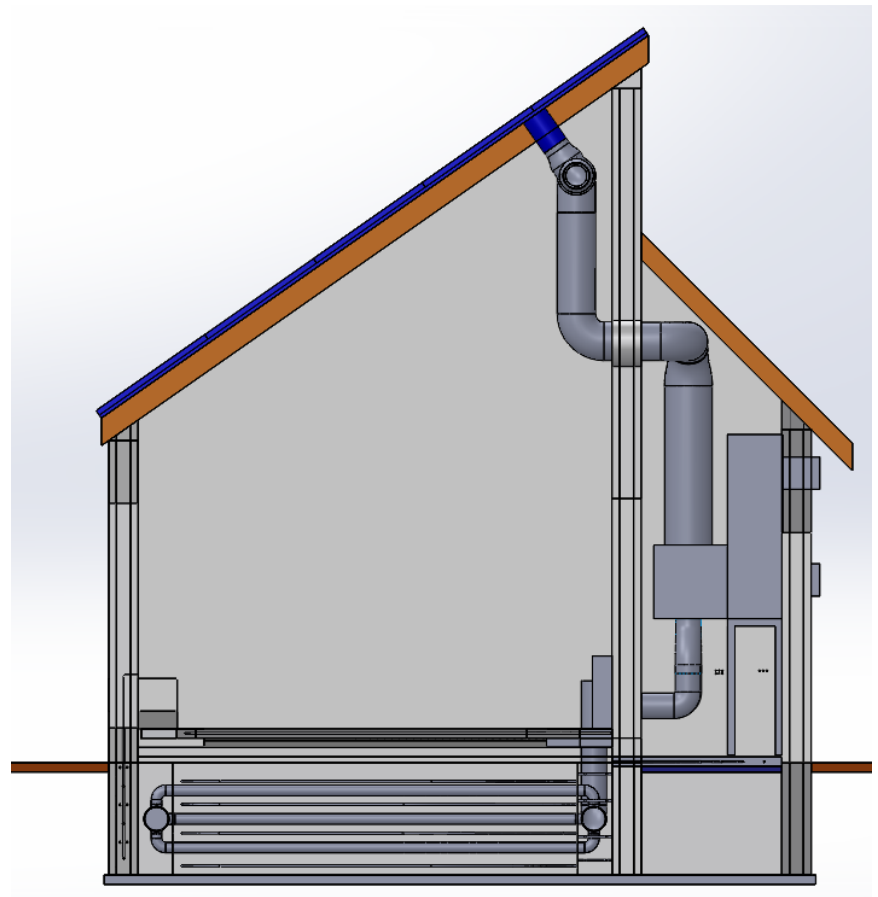

West view - Sand bed for thermal energy storage

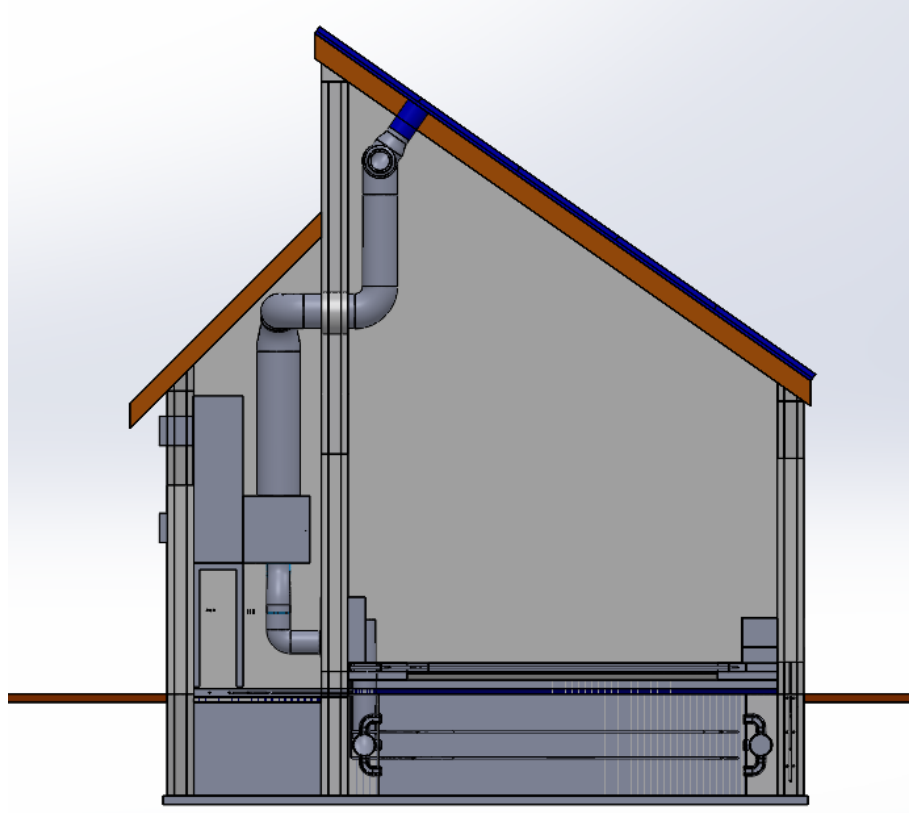

East view - Gravel bed for thermal energy storage 


\section{Appendix F: $\quad$ List of Journal and Conference Publications from this Research}

\section{Peer-reviewed Journal publications}

Ekrami N., Kamel R. S. and Fung A. S., "Design criteria and thermal performance of a building integrated ventilated concrete slab" ASHRAE Transaction, 2015 (Accepted).

Kamel R. S., and Fung, A. S. and Dash, P. R., "Solar systems and their integration with heat pumps: A review". Energy and Buildings, 87, 395-412, 2015.

Kamel R. S., and Fung, A. S., 2014, "Modeling, simulation and feasibility analysis of solar assisted heat pump for cold climate", Energy and Buildings, 82, 758-770, 2014.

Kamel R. S. and Fung A. S. , "Theoretical Estimation of the Performance of a PhotovoltaicThermal Collector (PV/T) System Coupled with a Heat Pump in a Sustainable Archetype House in Toronto", ASHRAE Transactions, 120(1), 179-191, 2014.

\section{Conference papers}

Kamel R. S. and Fung A. S., "Energy Saving and GHG Emission Reduction from Coupling Air Source Heat pump With Photovoltaic/Thermal Collector", ASME 2014 8th International Conference on Energy Sustainability, Jun 30-July 2, 2014, Boston, USA.

Ekrami, N, Kamel R. S., and Fung, A. S., "Effectiveness of a Ventilated Concrete Slab on an Air Source Heat Pump Performance in Cold Climate. eSim Building Simulation Conference, May 710, 2014, Carleton University, Canada.

Kamel R. S., Fung A. S. and Noire Q., (2013), "Feasibility of Building Integrated PhotovoltaicThermal Collector (BIPV/T) with Two-stage Variable Capacity Air Source Heat Pump in Toronto Area", 3rd Climate Change Technology Conference (CCTC), May 27-29, Concordia University, Montreal, Canada.

Kamel R. S., and Fung, A. S., "Modelling and characterization of transparent building integrated PV/T collector", 6th International Conference for Building Physics (IBPC), June 14-17, 2015, Torino, Italy.

Kamel R. S., Ekrami N., Dash P., Fung, A. S. and Hailu G., "BIPV/T+ASHP: Technologies for NZEBs", 6th International Conference for Building Physics (IBPC), June 14-17, 2015, Torino, Italy.

Vuong E., Kamel R. S. and Fung S. A., "A Comparative Study of BIPV/T System Simulation Tools: TRNSYS and EnergyPlus", 6th International Conference for Building Physics (IBPC), June 14-17, 2015, Torino, Italy. 
Ekrami, N, Kamel R. S., Amirirad A., and Fung, A. S, “Applications of Active Hollow Core Slabs and Insulated Concrete Foam Walls as Thermal Storage in Cold Climate Residential

Buildings" ", 6th International Conference for Building Physics (IBPC), June 14-17, 2015, Torino, Italy. 


\section{References}

Agrawal B. and Tiwari G. N., "Optimizing The Energy And Exergy of Building Integrated Photovoltaic Thermal (BIPVT) Systems Under Cold Climatic Conditions", Applied Energy, 87(2), 417-426, 2010.

Al-Amri A. M. S., "Solar Energy Utilization in Greenhouse Tomato Production", Agric. Sci., 9(1), 21-38, 1997.

Amvic Building System, AMVIC ICF, retrieved 2014 from http://www.amvicsystem.com/

ASHRAE Handbook, System and Equipment, America Society of Heating, Refrigerating and Air-Conditioning Engineers, 1967

Aste N., Chiesa G. and Verri F., "Design, development and performance monitoring of a photovoltaic-thermal (PVT) air collector”, Renewable Energy, 33(5), 914-927, 2008.

Athienitis A., "Design of Advance solar Homes Aimed at Net-Zero Annual Energy Consumption in Canada", NSERC Solar Buildings Research Network, 2007. Retrieved from http://www.worldenergy.org/documents/congresspapers/426.pdf

Badescu V., "Model of a Space Heating System Integrating a Heat Pump, Photothermal Collectors and Solar Cells", Renewable Energy, 27(4), 489-505, 2002a.

Badescu V., "Model of A Solar-Assisted Heat-Pump System for Space Heating Integrating a Thermal Energy Storage Unit", Energy and Buildings, 34(7), 715-726, $2002 \mathrm{~b}$.

Badescu V., "Model of a Thermal Energy Storage Device Integrated into a Solar-Assisted HeatPump System for Space Heating", Energy Conversion and Management, 44(10), 1589-1604, 2003.

Bai Y., Chow T. T., Menezo and Dupeyrat P., "Analysis of a Hybrid PV/Thermal Solar-Assisted Heat Pump System for Sports Center Water Heating Application", International Journal of Photoenergy, doi:10.1155/2012/265838, 2012.

Bakirci K. and Yuksel B., "Experimental Thermal Performance of A Solar Source Heat-Pump System for Residential Heating in Cold Climate Region", Applied Thermal Engineering, 31(8), 1508-1518, 2011.

Bambrook S. M and Sproul A. B., "Maximizing The Energy Output of A PVT Air System", Solar Energy, 86(6), 1857-1871, 2012.

Barnwal P. and Tiwari G. N., "Grape Drying by Using Hybrid Photovoltaic-Thermal (PV/T) Greenhouse Dryer: An Experimental Study”, Solar Energy, 82(12), 1131-1144, 2008. 
Barua R., Zhang D., Fung A. S., "Analysis of energy performance of the Sustainable Archetype House at Kortright Centre", First International High Performance Buildings Conference, July 12-15, West Lafayette, USA, 2010.

Barua R., Assessment and energy benchmarking for two archetype sustainable houses through comprehensive long term monitoring, in: MASc. Thesis, Department of Mechanical and Industrial Engineering, Ryerson University, Toronto, ON, 2010.

Bergene T. and Lovvik O. M., "Model Calculation on A Flat-Plate Solar Heat Collector with Integrated Solar Cells", Solar Energy, 55(6), 453-462, 1995.

Bertsch S. and Groll E., "Two-Stage Air-Source Heat Pump for Residential Heating and Cooling Applications in Northern U.S Climates", International Journal of Refrigeration, 31(7), 1282$1292,2008$.

Brandemuehl M. J. and Beckman W. A., "Transmission of diffuse radiation through CPC and flat plate collector glazings", Solar Energy, Vol. 24, 511-513, 1980.

Bridgeman A. and Harrison SJ., "Preliminary experimental evaluations of indirect solar assisted heat pump systems". In: 3rd Canadian solar building conference, August 20-22, Fredericton, New Brunswick, Canada; 2008.

Canadian Solar Inc., Canadian solar modules, 2014, http://www.canadiansolar.com/modulefinder.html

Candanedo, J.A. and A.K. Athienitis. "Predictive control of radiant floor heating and solar-source heat pump operation in a solar house”. HVAC\&R Research, 17(3):235-56. 2011.

Candanedo L.M., Athienitis A. and Park K., "Convective heat transfer coefficients in a buildingIntegrated photovoltaic/thermal system”, Solar Energy Engineering, 133, 2011.

Candanedo L. M., Athienitis A. K. and Candanedo J. A., O'Brien W. and Chen Y., " Transient and steady state models for open-loop air-based BIPV/T systems", ASHRAE Transactions. 116(1), 600-612, 2010.

Candanedo J. A. and Athienitis A. K., "Simulation of the Performance of A BIPV/T System Coupled to A Heat Pump in A Residential Heating Application", $9^{\text {th }}$ International IEA Heat Pump Conference, Zurich, Switzerland, 2008.

Cengel Y. A., Turner R. H. and Cimbala J. M., Thermal-Fluid Sciences, Third edition, McGrawHill 2008.

Chao Z., Xiaodan Z., Guanghui Z. and Yin L., "The Domestic Research Status of the Solar-Air Dual-Source Heat Pump", Intelligent System Design and Engineering Application (ISDEA), International Conference, 2, 643-646, 13-14 Oct. 2010, doi: 10.1109/ISDEA.2010.213 
Charalambous P. G., Maidment G. G., Kalogirou S. A. and Yiakoumetti K.," Photovoltaic Thermal (PV/T) Collectors: A review", Applied Thermal Engineering, 27(2-3), 275-286, 2007.

Chaturvedi S. K., Gagrani V.D. and Abdel-Salam T.M., "Solar-assisted heat pump - A sustainable system for low-temperature water heating applications", Energy Conversion and Management, 77, 550-557, 2014.

Chen Y., Athienitis A. K. and Galal K., "Modeling, design and thermal performance of a BIPV/T system thermally coupled with a ventilated concrete slab in a low energy solar house: Part 1, BIPV/T system and house energy concept", Solar Energy, 84(11), 1892-1907, 2010.

Chow T. T., Hand J. W. and Strachan P. A., "Building-Integrated Photovoltaic and Thermal Applications in a Subtropical Hotel Building", Applied Thermal Engineering, 23(16), 2035 2049, 2003.

Chow T. T., "A Review on Photovoltaic/Thermal Hybrid Solar Technology”, Applied Energy, 87(2), 365-379, 2010.

Chow TT, Li C and Lin Z., "Innovative solar windows for cooling-demand climate", Solar Energy Materials \& Solar Cells, 94, 212-220, 2010a.

Chow T. T., Fong K. F., Pei G., Ji J. and He M., "Potential Use of Photovoltaic-Integrated Solar Heat Pump System in Hong Kong”, Applied Thermal Engineering, 30(8), 1066-1072, 2010 b.

Chow T. T., Bai K. F. and Fong L. Z., "Analysis of a Solar Assisted Heat Pump System for Indoor Swimming Pool Water and Space Heating", Applied Energy, 100, 309-317, 2012.

Clara S., Solar PV module shipment to grow 30\% in 2014, According to NDP Solarbuzz. Retrieved from http://www.solarbuzz.com/news/recent-findings/solar-pv-module-shipmentsgrow-30-2014-according-npd-solarbuzz

Daghigh R., Ibrahim A., Jin G. L., Ruslan M. H. and Sopian K., "Predicting the Performance of Amorphous and Crystalline Silicon Based Photovoltaic Solar Thermal Collectors", Energy conversion and Management, 52(3), 1741-1747, 2011.

Day A. R. and Karayiannis T. G., "Solar-Assisted Heat Pump Research and Development", Building Serv. Eng. Res. Technol., 15(2), 71-80, 1994.

Dikici A. and Akbulut A., "Performance Characteristics and Energy-Exergy Analysis of Solar Assisted Heat Pump System”, Building and Environment, 43(11), 1961-1972, 2008.

Ecologix Heating Technologies Inc., Retrieved 2014 from:

http://www.ecologix.ca/products/ground-source-heat-pumps/

Eicker U. and Dalibard A., "Photovoltaic-Thermal Collectors for Night Radiative Cooling of Buildings", Solar Energy, 85(7), 1322-1335, 2011.

Eicker, U., Solar Technologies for Buildings. England: John Wiley \& Sons. Inc., 2003. 
Eiffert P. and Kiss G. J., Building-Integrated Photovoltaic Designs for Commercial and Institutional Structures, 2000, DIANE, http://books.google.com/

Ekrami N., Kamel R. S. and Fung A. S., "Design criteria and thermal performance of a buildingintegrated ventilated concrete slab", ASHRAE Transaction, volume 121, Part 2, 2015.

Ekrami N., Kamel R. S., Amirirad A. and Fung A. S., “Applications of Active Hollow Core Slabs and Insulated Concrete Foam Walls as Thermal Storage in Cold Climate Residential Buildings', $6^{\text {th }}$ International Building Physics Conference, IBPC2015, June 14-17, Turin, Italy, 2015a.

Ekrami N., Garat A., Fung A. S., "Thermal Analysis of Insulated Concrete Form (ICF) Walls". The 7th International Conference on Applied Energy (ICAE2015), March 28-31st, Abu Dhabi, UAE, 2015b.

Energy Use Data Handbook, Canada, http://data.gc.ca/data/en/dataset/23b85a02-a358-42b686c3-753b0355b616, 2013.

Environmental Commissioner of Ontario, energy conservation reports, 2012, http://www.eco.on.ca/index.php/en_US/pubs/energy-conservation-reports/cdm12v2-building$\underline{\text { momentum-results }}$

Evan D. L., "Simplified method for predicting photovoltaic array output", Solar Energy, 27(6), $555-560,1981$.

Facao J. and Carvalho M. J., "New test methodologies to analyze direct expansion solar assisted heat pumps for domestic hot water", Solar Energy, 100, 66-75, 2014.

Fanney A.H., Davis M.W. and Dougherty B.P., "Short-term characterization of buildingintegrated photovoltaic panels", in: Proceedings of the Solar Forum, Sunrise on the Reliable Energy Economy, June 15-19, ASES, Reno, NV, 2002.

Freeman T. L., Mitchell J. W. and Audit T. E., "Performance of Combined Solar-Heat Pump Systems," Solar Energy, 22(2), 125-135, 1979.

Fung T.Y and Yang H., "Study on thermal performance of semi-transparent building-integrated photovoltaic glazing”, Energy and Buildings, 40,341-351, 2008.

Gang P., Jie J., Wei H., Keliang L. and Hanfeng H., "Performance of Photovoltaic Solar Assisted Heat Pump System in Typical Climate Zone", Energy and Environment. vol. 6, 2007.

Garg, H.P. and Adhikari, R.S., "Conventional hybrid photovoltaic/thermal (PV/T) air heating collector: steady-state simulation”, Renewable Energy, 11, 363-385, 1997. 
Garg H. P. and Adhikari R. S., "Transient simulation of conventional hybrid photovoltaic/thermal (PV/T) air heating collectors", International Journal of Energy Research, 22(6), 547-562, 1998.

Gordon C. and Fung A., Analysis of time dependent valuation of emission factors from the electricity sector, in: Nayeripour Majid (Ed.), Sustainable Growth and Applications in Renewable Energy Sources, In Tech, ISBN 978-953-307-408-5, http://dx.doi.org/10.5772/27043, Available from:_http://www.intechopen.com/books/sustainable-growth-and-applications-in-renewableenergy-sources/analysis-of-time-dependent-valuation-of-emission-factors-from-the-electricitysector, 2011.

Gordon C. and Fung A., "Hourly emission factors from the electricity generation sector: a tool for analyzing the impact of renewable technologies in Ontario, Transactions of the Canadian Society for Mechanical Engineering, 33(1), 105-118, 2009.

Guiavarch A. and Peuportier B., "Photovoltaic Collectors Efficiency According to Their Integration in Buildings", Solar Energy, 80(1), 65-77, 2006.

Guler B., Ugursal V., Fung A., and Aydinalp M., “Technoeconomic evaluation of energy efficiency upgrade retrofits on the energy consumption and greenhouse gas emissions in the Canadian housing stock", International Journal of Environmental Technology and Management (IJETM), 9(4), 434-444, 2008.

Hachem C., Athienitis A. and Fazio P., "Design of Roofs for Increased Solar Potential BIPV/T Systems and Their Applications to Housing Units" ASHRAE annual conference, San Antonio, Texas, June, 2012.

Hailu, G. and Fung A., "Optimum tilt angle and orientation of solar panel for building integrated photovoltaic thermal (BIPV/T) application in Greater Toronto Area (GTA)”, 2013

Harrison S. J., Lin Q. and Mesquita L.C. S., "Integral Stagnation Temperature Control for Solar Collectors", SESCI Conference, University of Waterloo, Canada, 2004.

Hawlader M. N. A., Chou S. K., Jahangeer K. A., Rahman S. M. A. and Eugene Lau K.W., "Solar-assisted heat-pump dryer and water heater" Applied Energy, 74(1), 185-193, 2003.

Hawlader M. N. A. and Jahangeer K. A., "Solar Heat Pump Drying and Water Heating in the Tropics” Solar Energy, 80(5), 492-499, 2006.

Hawlader M. N. A., Rahman S. M. A. and Jahangeer K. A., "Performance of evaporatorcollector and air collector in solar assisted heat pump dryer" Energy Conversion and Management, 49(6), 1612-1619, 2008.

Husan M. A. and Sumathy K., "photovoltaic Thermal Module Concepts and Their Performance Analysis: review", Renewable and Sustainable Energy review, 14(7), 1845-1859, 2010. 
Hwang T., Kang S. and Kim J. T., "Optimization of the Building Integrated Photovoltaic System in Office Building-Focus on the Orientation, Inclined Angle and Installed Area”, Energy and Buildings, 46, 92-104, 2012.

Ibrahim A., Othman M. Y., Ruslan M. H., Mat S. and Sopian K., "Recent Advances in Flat Plate Photovoltaic/thermal (PV/T) Solar Collectors", Renewable and Sustainable Energy review, 15(1), 352-365, 2011.

IEA: International Energy Agency, solar energy prospective. Retrieved from: http://www.iea.org/publications/freepublications/publication/solar_energy_perspectives2011.pdf

ieso: Independent Electricity System Operator, 2014, http://microfit.powerauthority.on.ca/aboutmicrofit.

Infield D., Mei L. and Eicker U., "Thermal Performance Estimation for Ventilated PV Facades", Solar Energy, 76(1-3), 93-98, 2004.

Ito S., Kashima M. and Miura N., "Flow control and unsteady-state analysis on thermal performance of solar air collectors", Journal of Solar Energy Engineering, 128(3), 354-359, 2006.

Ji J., He H., Chow T., Pei G., He W. and Liu K., "Distributed Dynamic Modeling and Experimental Study of PV Evaporator in a PV/T Solar-Assisted Heat Pump", International Journal of Heat and Mass Transfer, 52(5), 1365-1373, 2009.

Ji J., Keliang L., Chow T. T., Gang P., Wei H. and Hanfeng H., "Performance Analysis of a Photovoltaic Heat Pump”, Applied Energy, 85(8), 680-693, 2008.

John A. D., William A. B., Solar Engineering of Thermal Processes, Third edition, John Wiley \&Sons Inc., New Jersey, 2006.

Joshi A. S., Tiwari A., Tiwari G. N., Dincer I. and Reddy B.V., "Performance evaluation of a hybrid photovoltaic thermal (PV/T) (glass-to-glass) system', International Journal of Thermal Science; 48(1), 154-164, 2009.

Kamthania D and Tiwari G.N., "Energy metrics analysis of semi-transparent hybrid PVT double pass facade considering various silicon and non-silicon based PV module Hyphen is accepted", Solar Energy, 100,124-140, 2014.

Kamthania D, Nayak S and Tiwari G. N., "Performance evaluation of a hybrid photovoltaic thermal double pass facade for space heating”, Energy and Buildings, 43 (9), 2274-2281, 2011.

Karagiorgas M., Galatis K., Tsagouri M., Tsoutsos T. and Valaskakis A., "Solar Assisted Heat Pump on Air Collectors: A Simulation Tool”, Solar Energy, 84(1), 66-78, 2010. 
Karkkainen S. and Oy E., Heat pumps for cooling and heating. Retrieved 2014 from: http://www.ieadsm.org/Files/Exco\%20File\%20Library/Key\%20Publications/HeatPumpReport_f inal.pdf

Karlsson F., Axell M. and Fahlén P., "Heat Pump Systems in Sweden-Country Report for IEA HPP Annex 28”, 2003 http://www.annex28.net/pdf/Annex28_N28.pdf

Kaygusuz K., "Calculation of Required Collector Area of a Solar-Assisted Series Heat Pump for Domestic Heating”, Energy sources, 22 (3), 247-256, 2000.

Kaygusuza K. and Ayhan T., "Experimental and theoretical investigation of combined solar heat pump system for residential heating”, Energy Conversion \& Management, 40(13), 1377-1396, 1999.

Kays W. M. and Crawford M. E., Convective Heat and Mass Transfer, Third edition, McGrawHill, New York, NY, 1993.

Khalifa A. J. N. and Abbas, E. F., "A comparative performance study of some thermal storage materials used for solar space heating”, Energy and Buildings, 2009, 41(4), 407-415.

Kiang C.S. and Jon C.K., Heat pump drying systems. In: Mujumdar AS, editor. Handbook of industrial drying. Boca Raton, FL, USA: Taylor \& Francis Inc.; 2006, p. 1104-5.

King D.L., Kratochvil J.A., Boyson W.E. and Bower W.I., "Field experience with a new performance characterization procedure for photovoltaic arrays", The Second World Conference and Exhibition on Photovoltaic Solar energy Conversion, July 6-10, 1998, Vienna, Austria, 1998a.

King D. L., Quintana M. A., Kratochvil J. A., Ellibee D. E. and Hansen B. R., Photovoltaic module performance and durability following long-term field exposure: National Center for Photovoltaics (NCPV) 15th Program Review Meeting, Sandia National Laboratories Albuquerque, NM 871850752, CO, USA, 1998.

Klein S. A., Beckman W. A. and Duffie J. A., Solar Heating Design by F-Chart Method. John Willey and Sons. Inc., New York, 1997.

Klein S. A., Duffie J. A. and Beckman W. A., "Transient considerations of flat-plate solar collectors", ASME Transaction, Journal of Eng. for Power, 96(2), 109-113, 1974.

Knier G., How do photovoltaics work? Retrieved from: http://science.nasa.gov/sciencenews/science-at-nasa/2002/solarcells/, July 2014.

Kong X. Q., Zhang D., Li Y. and Yang Q. M., "Thermal performance analysis of a directexpansion solar-assisted heat pump water heater" Energy, 36(12), 6830-6838, 2011. 
Konrad T., Are air source heat pumps a threat to geothermal heat pump supplies? 2014.

Retrieved from: http://www.forbes.com/sites/tomkonrad/2014/01/15/are-air-source-heat-pumpsa-threat-to-geothermal-heat-pump-suppliers/

Kuang Y. H., Wang R. Z. and Yu L. Q., "Experimental Study on Solar Assisted Heat Pump System for Heat Supply”, Energy conversion and Management, 44(7), 1089-1098, 2003.

Kumar R. and Rosen M. A., "A Critical Review of Photovoltaic -Thermal Solar Collectors for Air Heating”, Applied Energy, 88(11), 3603-3614, 2011.

Li Y. W., Wang R. Z., Wu J. Y. and Xu Y. X., "Experimental performance analysis and optimization of a direct expansion solar-assisted heat pump water heater", Energy, 32(8), 13611374, 2007a.

Li Y. W., Wang R. Z., Wu J. Y. and Xu Y. X.,' Experimental Performance Analysis on a DirectExpansion Solar-Assisted Heat Pump Water Heater", Applied Thermal Engineering, 27(17), 2858-2868, 2007b.

Liang C., Zhang X., Li X. and Zhu X., "Study on the Performance of a Solar Assisted Air Source Heat Pump System for Building Heating”, Energy and Buildings, 43(9), 2188-2196, 2011.

Li DHW, Lam TNT, Chan WWH and Mak AHL., "Energy and cost analysis of semi-transparent photovoltaic in office buildings", Applied Energy, 86 (5), 722-729, 2009.

Li H. and Yang H., "Potential application of solar thermal systems for hot water production in Hong Kong”, Applied Energy, 86(2), 175-180, 2009.

Liu K., Ji J., Chow T. T., Pei G., He H., Jiang A. and Yang J., "Performance Study of A Photovoltaic Solar Assisted Heat Pump with Variable-Frequency Compressor: A Case Study in Tibet", Renewable Energy, 34(12), 2680-2687, 2009.

Liu Y., Ma J. and Zhou G., "The Coupling Performance of a Solar-Air Heat Pump", Procedia Engineering, 15, 4058-4062, 2011.

Loveday D. L., "Solar-assisted heat pump systems: Assessment of an example using profiled steel cladding”, Building Serv. Eng. Technol., 13(1), 37-42, 1992.

Mauthner F. and Weiss W., "Solar Heat Worldwide", IEA Solar Heating \& Cooling Program. Retrieved from: http://www.iea-shc.org/data/sites/1/publications/Solar-Heat-Worldwide-2014.pdf, June 2014.

McQuiston F. C., Parker J. D. and Spitler J. D., Heating, Ventilating, and Air Conditioning analysis and design, Sixth Edition, John Willey and Sons. Inc., New York, 2005.

Miyazaki T, Akisawa A, Kashiwagi T., "Energy saving of office buildings by the use of semitransparent solar cells for windows”, Renewable Energy, 30 (3), 281-304, 2005. 
Montoro D. F., Vanbuggenhout P. and Ciesielska J., Building integrated Photovoltaics: An overview of the existing products and their fields of application, 2012. Retrieved from: http://www.cagbctoronto.org/files/BIPV_Overview_existing_products.pdf

Moshfegh B. and Sandberg M., "Investigation of Fluid Flow and Heat Transfer in A Vertical Channel Heated From One Side by PV Elements: Part I - Numerical Study", Renewable Energy, 8(1), 248-253, 1996.

Moshfegh B. and Sandberg M., "Flow and Heat Transfer in the Air Gap Behind Photovoltaic Panels", Renewable and Sustainable Energy, 2(3), 287- 301, 1998.

Nayak S. and Tiwari G. N., "Energy and exergy analysis of photovoltaic/thermal integrated with a solar greenhouse”, Energy and Buildings, 40(11), 2015-2021, 2008.

Nayak S. and Tiwari G. N., "Theoretical Performance Assessment of an Integrated Photovoltaic and Earth Air Heat Exchanger Greenhouse Using Energy an Exergy Analysis Methods", Energy and Buildings, 41(11), 888-896, 2009.

Nayak S. and Tiwari G. N., "Energy Metrics of Photovoltaic/Thermal and Earth Air Heat Exchanger Integrated Greenhouse for Different Climate Conditions of India", Applied Energy, 87, 2984-2993, 2010.

Needham S., Renewable energy technologies update. , 2009. Retrieved from: http://www.aph.gov.au/binaries/library/pubs/bn/sci/renewableenergy.pdf

NRCan, Energy efficiency trends in Canada, December 2011. Retrieved from: http://oee.nrcan.gc.ca/publications/statistics/trends11/pdf/trends.pdf

Omojaro P. and Breitkopf C., "Direct expansion solar assisted heat pumps: A review of applications and recent research", Renewable and Sustainable Energy Reviews, 22, 33-45, 2013.

Ontario Reg. 541/05: Net Metering, 2005, https://www.e-laws.gov.on.ca/html/source/regs/english/2005/elaws_src_regs_r05541_e.htm

Ozgener O. and Hepbasli A., "A Review on the Energy and Exergy Analysis of Solar Assisted Heat Pump Systems", Renewable and Sustainable Energy Reviews, 11(3), 482-496, 2007.

Pareto V. E. and Pareto M. P. The Urban Component of the Energy Crisis, 2008. Retrieved from: http://mpra.ub.uni-muenchen.de/13989/1/VEP_MPP-Urban_Component_Energy_Crisis_SSRNid1221622.pdf

Pogharian S., Ayoub J., Candanedo J. A. and Athienitis A. K., "Getting to a Net Zero Energy Lifestyle in Canada: The Alstonvale Net Zero Energy House", 23th European PV Solar Energy Conference, Valencia, Spain, 2008.

Pendyala V. R., Devotta S. and Patwardhan V. S., "The Economics of Heat Pump Assisted Drying Systems", Hear Recovery System, 6(6), 433-442, 1986. 
Pendyala V. R., Devotta S. and Patwardhan V. S., "Heat-pump-assisted dryer. Part 1:

Mathematical model", International Journal of Energy Research, 14(5), 479-92, 1990.

Prakash, J., "Transient analysis of a photovoltaic/thermal solar collector for co-generation of electricity and hot air/water", Energy Conversion and Management, 35, 967-972, 1994.

Rad F. M., Fung A. S. and Leong W. H., "Feasibility of Combined Solar Thermal and Ground Source Heat Pump Systems in Cold Climate, Canada", Energy and Buildings, 61, 224-232, 2013.

Routh K., Dieckmann J., Brodrick J., "Heat pumps for cold climates", ASHRAE Journal, 51(2), 69, 2009.

Ruschenburg J., Herkel S. and Henning H., “A Statistical Analysis on market-available Solar Thermal Heat Pump Systems”, Solar Energy, 95, 79-89, 2013.

Safa A. A., Fung A. S. and Kumar R., "Comparative thermal performance of a ground source heat pump and a variable capacity air source heat pump systems for sustainable houses", Applied Thermal Engineering, 81, 279-287, 2015.

Safa A., Fung A., and Kumar R., "Performance of two-stage variable capacity air source heat pump: Field performance results and TRNSYS simulation”, Energy and Buildings 94, 80-90, 2015a.

Safa A., Seters T. S. and Fung A., "Performance Assessment of a Variable Capacity Air Source Heat Pump and a Single-Capacity Horizontal Loop Coupled Ground Source Heat Pump System", $11^{\text {th }}$ IEA Heat Pump Conference, May 12-16, 2014, Montréal (Québec) Canada.

Safa A. A., Fung A. S. and Leong W. H., "Part Load Performance of a Two-stage Variable Speed Air Source Heat Pump System in Cooling Mode", ASHRAE 2011 Annual Conference, Montreal, QC, June 25-29, 2011a.

Safa A. A., Fung A. S. and Leong W. H., "The Archetype Sustainable House: Performance Simulation of a Variable Capacity Two stage Air Source Heat Pump System", Building Simulation 2011, Sydney, Australia, November 14-16, 2011 b.

Sandberg M. and Moshfegh B., "Investigation of Fluid Flow and Heat Transfer in A Vertical Channel Heated From One Side by PV Elements: Part II - Experimental Study", Renewable Energy, 8(1), 254-258, 1996.

Sandberg M. and Moshfegh B., "Ventilated-Solar Roof Air Flow and Heat Transfer Investigation”, Renewable Energy, 15(1), 287- 292, 1998.

Sandberg M. and Moshfegh B., "Buoyancy-Induced Air Flow in Photovoltaic Facades: Effect of Geometry of the Air Gap and Location of Solar Cell Modules", Building and Environment, 37(3), 211-218, 2002.

Sandia National Laboratories, Database of Photovoltaic Module Performance Parameters, Sandia National Laboratories, 2002. Retrieved from: http://www.sandia.gov/pv/docs/Database.htm. 
Skoplaki E. and Palyvos J.A., "On the temperature dependence of photovoltaic module electrical performance: A review of efficiency/power correlations", Solar Energy, 83(5), 614-624, 2009.

Sopian K., Yigit K. S., Liu H. T., KakaÇ S. and Veziroglu T. N., "Performance analysis of photovoltaic thermal air heaters", Energy Conversion and Management, 37(11), 1657-1670, 1996.

Soto W. D., Klein S. A., Beckman W. A., "Improvement and validation of a model for photovoltaic array performance", Solar Energy, 80, 78-88, 2006.

Sterling S. J. and Collins M. R., "Feasibility analysis of an indirect heat pump assisted solar domestic hot water system", Applied Energy, Vol. 93, 11-17, 2012.

Stevens V., Craven C. and Graber-Slaght R., "Air Source Heat Pumps in Southeast Alaska” Cold Climate Housing Research Centre (CCHRC), 2013.

Terrell R. E., "Performance and analysis of a "series" heat pump-assisted solar heated residence in Madison, Wisconsin", Solar Energy, 23(5), 451-453, 1979.

Tiwari G. N., Mishra R. K. and Solanki S. C., "Photovoltaic modules and their applications: A review on thermal modeling", Applied Energy, 88, 2287-2304, 2011.

Tom P. Hough,” Solar Energy: New Research”, 2006, Nova Science Inc. New York, NY.

Tonui J. K. and Tripanaganostopoulos Y., "Improved PV/T Solar Collectors With Heat Extraction by Forced or Natural Circulation”. Renewable Energy, 32(4), 623-637, 2007a.

Tonui J.K. and Tripanaganostopoulos Y. "Air-cooled PV/T solar collectors with low cost performance improvements”, Solar Energy, 81(4), 498-511, 2007b.

Toronto Hydro, 2014. Retrieved from:

http://www.torontohydro.com/sites/electricsystem/residential/yourbilloverview/Pages/Electricity Rates.aspx.

Transition Chepstow Energy Group, 2014. Retrieved on Jan 2014 from: http://www.transitionchepstow.org.uk/wp-content/uploads/2011/01/Some-Example-MCSaccredited-PV-panel-dimensions-in-millimetres.pdf.

TRCA: Toronto and Region Conservation Authority, The Archetype Sustainable House, http://www.sustainablehouse.ca/about/mission.dot, Vaughan, ON, Canada, 2009

Tripanaganostopoulos Y., "Aspect and Improvement of Hybrid Photovoltaic/Thermal Solar Energy Systems". Journal of Solar Energy, 81(3), 1117-1131, 2007.

Tripanagnostopoulos Y., Nousia Th., Souliotis M. and Yianoulis P., "Hybrid Photovoltaic/Thermal Solar Systems", Solar Energy, 72(3), 217-234, 2002. 
TRNSYS17, Reference Manual, Solar Energy Laboratory, Univ. of Wisconsin-Madison, Madison, 2012.

Umezu K. and Suma S., "Heat Pump Room Air-Conditioner Using Variable Capacity Compressor". ASHRAE Transactions, 335-349, 1984.

Vats K. and Tiwari G. N., "Performance Evaluation of a Building Integrated Semitransparent Photovoltaic Thermal System for Roof and Facade", Energy and Buildings, 45, 211-218, 2007.

Vokas G., Christandonis N. and Skittides F., "Hybrid Photovoltaic-Thermal Systems for Domestic Heating and Cooling- A Theoretical Approach", Solar Energy, 80(5), 607-615, 2006.

Vuong E., Kamel R. S. and Fung S. A., "A Comparative Study of BIPV/T System Simulation Tools: TRNSYS and EnergyPlus”, 6th International Conference for Building Physics (IBPC), June 14-17, 2015, Torino, Italy.

Wang Q., Liu Y., Liang G., Li J., Sun S. and Chen G., "Development and Experimental Validation of A Novel Indirect-Expansion Solar-Assisted Multifunctional Heat Pump", Energy and Buildings, 43(2-3), 300-304, 2011.

Wang E., Fung A. S., Qi C. and Leong W. H., "Performance prediction of a hybrid solar groundsource heat pump system" Energy and Buildings, 47, 600-611, 2012.

Wong P. W., Shimoda Y., Nonaka M., Inoue M. and Mizuno M., "Semi-transparent PV: Thermal performance, power generation, daylight modelling and energy saving potential in a residential application”, Renewable Energy, 33(5), 1024-1036, 2008.

Xu G.Y., Zhang X. S. and Deng S. M., "A simulation study on the operating performance of a solar-air source heat pump water heater", Applied Thermal Engineering, 26(11), 1257-1265, 2006.

Zhai X. Q., Dai Y. J. and Wang R. Z., "Comparison of heating and natural ventilation in a solar house induced by two roof solar collectors", Applied Thermal Engineering, 25, 741-757, 2005.

Zhang D., Barua R., Fung A., "Development of monitoring system for the Sustainable Archetype House at Kortright Centre", First International High Performance Buildings Conference, July 12-15, West Lafayette, USA, 2010.

Zogou O. and Stapountzis H., "Flow and Heat Transfer Inside A PV/T Collector for Building Application”, Applied Energy, 91(1), 103-115, 2012.

Zondag, H.A., "Flat-plate PV-Thermal collectors and systems: A review", Renewable and Sustainable Energy Reviews, 12 (4), 891-959, 2008. 